\title{
AVALIAÇÃO DE COMPOSTOS ORGÂNICOS VOLÁTEIS EM AMBIENTES INTERIORES CLIMATIZADOS
}

\section{ROGÉRIO APARECIDO MACHADI}

Tese apresentada ao Departamento de Saúde Ambiental da Faculdade de Saúde Pública da Universidade de São Paulo para obtenção do Grau de Doutor em Saúde Pública.

Área de concentração: Saúde Ambiental

ORIENTADOR: PROF. DR. JOÃO VICENTE DE ASSUNÇÃO

São Paulo

2003

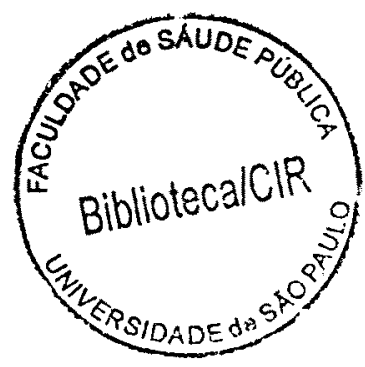


Y4016/2003 doc

Autorizo, exclusivamente para fins acadêmicos e cientificos, a reprodução total ou parcial desta tese, por processos fotocopiadores.

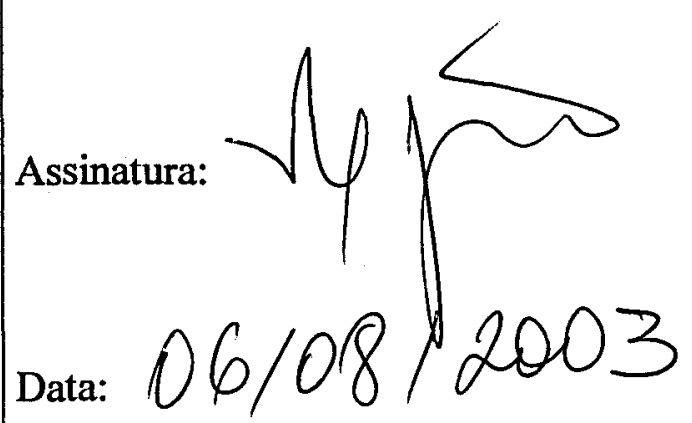


À minha esposa $e$ filha, verdadeiras luzes de minha vida, pelo amor, incentivo e compreensão, sem os quais tudo isto seria impossível. 


\section{AGRADECIMENTOS}

Ao Pai, Todo Poderoso do Amor, obrigado pela luz que iluminou e ilumina meu caminho, que eu seja um instrumento de sua Paz e dignifique a honra de ser teu filho.

Ao Professor Doutor João Vicente de Assunção pela orientação e boa vontade durante todo o curso.

À Luíza Maria Nunes Cardoso pelo auxílio técnico e amizade.

Ao amigos da FUNDACENTRO: Carlos, Hyris, Luciana e Paulo pelo incentivo e ajuda em horas complicadas.

Ao Instituto Presbiteriano Mackenzie pela oportunidade cedida a mim e apoio integral para consolidação deste doutorado.

À FUNDACENTRO pelo apoio técnico cedendo todos os equipamentos necessários para que esta tese fosse desenvolvida. 


\section{RESUMO}

Machado RA. Avaliação de compostos orgânicos voláteis em ambientes interiores climatizados. São Paulo; 2003. [Tese de Doutorado - Faculdade de Saúde Pública da Universidade de São Paulo].

Tomando por base a Portaria 176 da Agência Nacional de Vigilância Sanitária que cita a necessidade do levantamento de dados sobre compostos orgânicos voláteis COV- existentes em ambientes fechados climatizados de atividades ocupacionais, foram analisados os compostos orgânicos voláteis no ar interior e exterior de escritórios climatizados do centro da cidade de São Paulo com ausência de tabagismo. As análises foram quantitativas para tetracloreto de carbono, clorofórmio, benzeno e tolueno e qualitativas para as demais substâncias. As amostras foram coletadas através de tubos com carvão ativado e as análises realizadas por Cromatografia Gasosa/Espectrometria de Massas. Foram validados os métodos de coleta e análise utilizados, segundo critério do National Institute for Occupational Safety and Health (NIOSH). Os resultados mostraram ausência de clorofórmio e apenas algumas amostras acusaram traços de tetracloreto de carbono, mas em 76,7\% das amostras foi encontrado benzeno e em $100 \%$ foi encontrado tolueno, sendo estes em concentrações similares às encontradas na literatura estrangeira. Qualitativamente também foram encontradas as mesmas substâncias citadas nos ambientes interiores climatizados de outros países. Como conclusões foi verificada a existência de COV potencialmente nocivos para saúde, no ar interior de ambientes climatizados, mesmo com ausência de tabagismo. A metodologia adaptada para realizar as coletas e análises demonstrou ser uma alternativa viável e confiável em relação às existentes na literatura técnica. Também foi constatado que a maioria dos COV presentes no ar dos escritórios pesquisados tinham por fonte o ar externo e que os condicionadores de ar tipo SPLIT e de janela concentram as substâncias no ar interno, enquanto os condicionadores centrais promovem a diluição destas substâncias.

Palavras-chave: Compostos Orgânicos Voláteis; Interiores Climatizados; Poluição do ar de Interiores; Avaliação. 


\section{SUMMARY}

Machado RA. Analysis of volatile organic compounds in acclimatized indoor cnvironments. São Paulo; 2003. [Doctorate Thesis - Faculdade de Saúde Pública da Universidade de São Paulo (School of Public Health, University of São Paulo)].

In accordance with Portaria 176 of Agência Nacional de Vigilância Sanitária, that mentions the need of a data collection of volatile organic compounds -VOC- existing in occupational activity closed acclimatized environments, volatile organic compounds were analyzed in the indoor, and outdoor air of São Paulo City downtown acclimatized offices, where there was no tobacco smoking. Analyses were quantitative for carbon tetrachloride, chloroform, benzene, and toluene, and qualitative for the other substances. Samples were taken into tubes with activated carbon and analyses were performed by Gas Chromatography/Mass Spectrometry. The sampling and analyzing methods used were validated in compliance with criteria of the National Institute for Occupational Safety and Health (NIOSH), USA. Results showed chloroform absence, and only some samples indicated carbon tetrachloride traces, but in $76.7 \%$ of the samples benzene was found and in $100 \%$ of the samples toluene was detected, these substances were in similar concentrations to those found, respectively, in the foreign literature. Qualitatively, the same substances, as mentioned to be in other countries' acclimatized indoor environments, were also found. As a conclusion, the existence of VOC, potentially harmful for the health, was observed in the air of acclimatized environments, even though without tobacco smoking. The methodology adapted to take the samples, and perform the analyses, proved to be a viable, and reliable alternative if compared to those existing in the technical literature. It was also found out that most part of the VOC present in the air of the investigated offices had outside air as a source, and SPLIT, and window-type air conditioners concentrate these substances in the indoor air, while central air conditioners provide dilution of these substances.

Key-words: Volatile Organic Compounds; Acclimatized Indoor; Indoor Air Pollution; Analysis. 


\section{SUMÁRIO}

página

\section{1- INTRODUÇÃO}

1.1- Poluição do ar - Poluentes Orgânicos 01

1.2- Estudo dos Compostos Orgânicos 02

1.3- Caracterização dos Compostos Orgânicos 04

1.4- Ambientes interiores 05

1.5- Fontes de Compostos Orgânicos Voláteis 07

1.5.1- Fontes internas de Compostos Orgânicos Voláteis $\quad 07$

1.5.2- Fontes de Compostos Orgânicos Voláteis em ambientes externos 12

1.6- Efeitos à saúde $\quad 14$

1.6.1- Efeitos agudos dos Compostos Orgânicos Voláteis $\quad 15$

1.6.2- Efeitos crônicos - carcinogenicidade e genotoxicidade 20

1.7- Benzeno e hidrocarbonetos clorados leves 24

1.7.1- Toxicidade 24

1.7.1.1- Benzeno 25

1.7.1.2- Clorofórmio 25

1.7.1.3- Tetracloreto de carbono 26

1.7.1.4- Tolueno 27

1.8- Legislação 28

1.9- Revisão de metodologias analíticas e amostragens 30

1.9.1- Métodos de amostragem de compostos orgânicos no ar 30

1.9.1.1- Carvão ativado $\quad 30$

1.9.1.2- Tenax 31

1.9.1.3- Sistemas multiadsorventes 31

1.9.1.4- Amostragem direta $\quad 32$

1.9.1.5- Comparação de métodos de amostragem 32

1.9.2- Métodos de análise de compostos orgânicos voláteis 33 


\section{2- OBJETIVOS}

2.1- Objetivo Geral 36

2.2- Objetivos Específicos 36

2.3- Hipótese 37

3- MATERIAIS E MÉTODOS

3.1- Região de estudo 38

3.2- Método de análise $\quad 39$

3.2.1- Instrumentação analítica $\quad 42$

3.2.2- Reagentes e padrões $\quad 42$

3.2.2.1- Solução estoque $\quad 43$

3.2.2.2- Padrões analíticos 43

3.2.3- Validação do sistema de detecção 44

3.2.3.1 - Determinação do Limite de deteç̧ão do Método Analítico 44

3.2.3.2- Determinação da Precisão e Recuperação do Método Analítico 45

3.3- Método de coleta 46

3.3.1- Materiais utilizados nas coletas 46

3.3.2- Validação do método de coleta 48

3.3.3- Avaliação do adsorvente e do dessorvedor 50

3.4- Pontos de coleta de amostra 50

3.4- Avaliação estatística das amostras 57

4- RESULTADOS e DISCUSSÕES 58

4.1- Validação baseada no critério NIOSH para o método analítico $\quad 58$

4.1.1- Limite de Detecção do Método Analítico 58

4.1.1.1- Discussão do Limite de Detecção do Método 
Analítico 63

4.1.2- Precisão e Recuperação do Método Analítico 63

4.1.2.1- Cálculos utilizados para determinação da

Precisão e Recuperação do Método Analítico 64

4.1.2.2- Discussão sobre Precisão e Recuperação do Método Analítico 71

4.2- Validação do método de coleta 72

4.2.1- Discussão do método de coleta 73

4.3- Avaliação do adsorvente e dessorvedor $\quad 74$

4.3.1- Discussão da avaliação do Adsorvente e Dessorvedor $\quad 75$

4.4- Medições ambientais 76

4.4.1- Resultados Quantitativos $\quad 80$

4.4.1.1- Discussão dos resultados quantitativos 96

$\begin{array}{ll}\text { 4.4.2- Resultados Qualitativos } & 104\end{array}$

4.4.2.1- Discussão dos resultados qualitativos 121

4.5- Avaliação estatística das amostras 122

5- CONCLUSÕES 123

6- RECOMENDAÇÕES 126

$\begin{array}{ll}\text { 7- BIBLIOGRAFIA } & 127\end{array}$ 


\section{ANEXOS}

Anexo 1- Resolução $n^{\circ} 9$ da Agência Nacional de Vigilância Sanitária

Anexo 2- Exemplo de cromatograma obtido de análise pelo modo SCAN

Anexo 3- Exemplo de cromatograma obtido de análise de benzeno pelo modo SIM

Anexo 4- Exemplo de cromatograma obtido de análise de tolueno pelo modo SIM

Anexo 5- Exemplo de cromatograma obtido de análise de clorofórmio pelo modo SIM

Anexo 6- Exemplo de cromatograma obtido de análise de tetracloreto de carbono pelo modo SIM 


\section{LISTA DE FIGURAS}

página

Figura 1- Área "versus" micrograma de Tetracloreto de carbono para cálculo do limite de detecção

Figura 2- Área "versus" micrograma de clorofórmio para cálculo do limite de detecção

Figura 3- Área "versus" micrograma de benzeno para cálculo do limite de detecção

Figura 4- Área "versus" micrograma de tolueno para cálculo do limite de detecção

Figura 5- Comparação entre as amostras 1 (ar externo) e 2 (ar interno)

Figura 6- Comparação entre as amostras 3 (ar externo), 4 (ar interno) e 5 (ar interno)

Figura 7- Comparação entre as amostras 6 (ar externo), 7 (ar interno), 8 (ar interno) e 9 (ar interno)

Figura 8- Comparação entre as amostras 10 (ar externo) e 12 (ar interno)

Figura 9- Comparação entre as amostras 11 (ar externo) e 13 (ar interno)

Figura 10- Comparação entre as amostras 14 (ar externo) e 15 (ar interno)

Figura 11- Comparação entre as amostras 16 (ar externo) e 17 (ar interno)

Figura 12- Comparação entre as amostras 18 (ar externo) e 19 (ar interno)

Figura 13- Comparação entre as amostras 21 (ar externo), 20 (ar interno), 22 (ar interno) e 23 (ar interno)

Figura 14- Comparação entre as amostras 25 (ar externo) e 24 (ar interno) 88

Figura 15- Comparação entre as amostras 29 (ar externo) e 26 (ar interno)

Figura 16- Comparação entre as amostras 27 (ar externo) e 28 (ar interno)

Figura 17- Comparação entre as amostras 30 (ar externo) e 31 (ar interno) 
Figura 18- Comparação entre as amostras 32 (ar externo) e 33 (ar interno) 90

Figura 19- Comparação entre as amostras 34 (ar externo) e 35 (ar interno) 91

Figura 20- Comparação entre as amostras 36 (ar externo) e 37 (ar interno) 91

Figura 21- Comparação entre as amostras 38 (ar externo) e 39 (ar interno) 92

Figura 22- Comparação entre as amostras 40 (ar externo) e 41 (ar interno) 92

Figura 23- Comparação entre as amostras 42 (ar externo) e 43 (ar interno) 93

Figura 24- Comparação entre as amostras 44 (ar externo) e 45 (ar interno) 93

Figura 25- Comparação entre as amostras 46 (ar externo) e 47 (ar interno) 94

Figura 26- Comparação entre as amostras 48 (ar externo) e 49 (ar interno) 94

Figura 27-Comparação entre as amostras 50 (ar externo) e 51 (ar interno) 95

Figura 28- Comparação entre as amostras 52 (ar externo), 53 (ar interno) e

54 (ar interno) 95 


\section{LISTA DE TABELAS}

página

Tabela 1- Classificação dos poluentes orgânicos de ambientes interiores

Tabela 2-Compostos orgânicos voláteis mais freqüentes e suas fontes

Tabela 3- Fatores de emissão para materiais que emitem vapores orgânicos

Tabela 4- Concentrações médias (ppbv) de alguns compostos orgânicos voláteis no ar da cidade de São Paulo, em novembro de 1998, obtidas com tubos amostradores e de estudo em Los Angeles feito por Lonneman

Tabela 5- Parâmetros de carcinogenicidade de poluentes do ar ambienatal de interiores

Tabela 6- Tipo de padrão por massa de substância contida por mililitro

Tabela 7- Resumo dos tipos mais comuns para geração de atmosferas controladas e suas especificações

Tabela 8- Dados para cálculo do limite de detecção do tetracloreto de carbono

Tabela 9- Dados para cálculo do limite de detecção do clorofórmio

Tabela 10- dados para cálculo do limite de detecção do benzeno

Tabela 11- dados para cálculo do limite de detecção do tolueno

Tabela 12- Teste de precisão para tetracloreto de carbono

Tabela 12- Teste de precisão para clorofórmio

Tabela 13- Teste de precisão para benzeno

Tabela 14- Teste de precisão para tolueno

Tabela 15- Resultados dos Coeficientes de Variação (Cv) das substâncias por experiência

Tabela 16- Teste de recuperação do método para tetracloreto de carbono 
Tabela 17- Teste de recuperação do método para clorofórmio

Tabela 18- Teste de recuperação do método para benzeno $\quad 71$

Tabela 19- Teste de recuperação do método para tolueno $\quad 71$

Tabela 20- Áreas médias de seis análises de tubos de cada substância por periodos de amostragem

Tabela 21- Resultados das análises de tetracloreto de carbono, clorofórmio Benzeno e tolueno por tubo no teste de nove horas de coleta

Tabela 22- Resultados de desvio padrão e CV por substância na coleta de nove horas

Tabela 23- Massa de substâncias inseridas nos tubos amostradores

Tabela 24- Eficiência de extração de tetracloreto de carbono

Tabela 25- Eficiência de extração de clorofórmio

Tabela 26- Eficiência de extração de benzeno

Tabela 27- Eficiência de extração de tolueno

Tabela 28- Condições ambientais por dia de coleta

Tabela 29- Identificação dos pontos de amostras por datas de coleta e análise

Tabela 30- Resultados das análises de tetracloreto de carbono $\left(\mathrm{CCL}_{4}\right)$, Clorofórmio $\left(\mathrm{HCCl}_{3}\right)$, benzeno e tolueno por amostra

Tabela 31- Relação de substâncias encontradas nas amostras de ar externo e interno pelo modo SCAN

Tabela 32- Comparação entre as amostras 1 e 2 quanto as substâncias encontradas através das análises qualitativas pelo modo SCAN

Tabela 33- Comparação entre as amostras 3, 4 e 5 quanto as substâncias encontradas através das análises qualitativas pelo modo SCAN

Tabela 34- Comparação entre as amostras 6, 7, 8 e 9 quanto as substâncias encontradas através das análises qualitativas pelo modo SCAN

Tabela 35- Comparação entre as amostras 10 e 12 quanto as substâncias encontradas através das análises qualitativas pelo modo SCAN

Tabela 36- Comparação entre as amostras 11 e 13 quanto as substâncias encontradas através das análises qualitativas pelo modo SCAN 
Tabela 37- Comparação entre as amostras 14 e 15 quanto as substâncias encontradas através das análises qualitativas pelo modo SCAN

Tabela 38- Comparação entre as amostras 16 e 17 quanto as substâncias encontradas através das análises qualitativas pelo modo SCAN

Tabela 39- Comparação entre as amostras 18 e 19 quanto as substâncias encontradas através das análises qualitativas pelo modo SCAN

Tabela 40- Comparação entre as amostras 21, 20, 22 e 23 quanto as substâncias encontradas através das análises qualitativas pelo modo SCAN

Tabela 41- Comparação entre as amostras 25 e 24 quanto as substâncias encontradas através das análises qualitativas pelo modo SCAN

Tabela 42- Comparação entre as amostras 29 e 26 quanto as substâncias encontradas através das análises qualitativas pelo modo SCAN

Tabela 43-Comparação entre as amostras 27 e 28 quanto as substâncias encontradas através das análises qualitativas pelo modo SCAN

Tabela 44- Comparação entre as amostras 30 e 31 quanto as substâncias encontradas através das análises qualitativas pelo modo SCAN

Tabela 45- Comparação entre as amostras 32 e 33 quanto as substâncias encontradas através das análises qualitativas pelo modo SCAN

Tabela 46- Comparação entre as amostras 34 e 35 quanto as substâncias encontradas através das análises qualitativas pelo modo SCAN

Tabela 47- Comparação entre as amostras 36 e 37 quanto as substâncias encontradas através das análises qualitativas pelo modo SCAN

Tabela 48- Comparação entre as amostras 38 e 39 quanto as substâncias encontradas através das análises qualitativas pelo modo SCAN

Tabela 49- Comparação entre as amostras 40 e 41 quanto as substâncias encontradas através das análises qualitativas pelo modo SCAN

Tabela 50- Comparação entre as amostras 42 e 43 quanto as substâncias encontradas através das análises qualitativas pelo modo SCAN

Tabela 51- Comparação entre as amostras 44 e 45 quanto as substâncias encontradas através das análises qualitativas pelo modo SCAN 
Tabela 52- Comparação entre as amostras 46 e 47 quanto as substâncias encontradas através das análises qualitativas pelo modo SCAN

Tabela 53- Comparação entre as amostras 48 e 49 quanto as substâncias encontradas através das análises qualitativas pelo modo SCAN

Tabela 54- Comparação entre as amostras 50 e 51 quanto as substâncias encontradas através das análises qualitativas pelo modo SCAN

Tabela 55- Comparação entre as amostras 52, 53 e 54 quanto as substâncias encontradas através das análises qualitativas pelo modo SCAN 


\section{ABREVIATURAS}

4-PC- 4-fenilciclohexeno

ACGIH- American Conference of Governmental Industrial Hygienists.

ASHRAE-' American Society of Heating, Refrigerating and Air Conditioning Engineers.

BRI- Building-related illness (doença relacionada com o edifício).

CONAMA- Conselho Nacional do Meio Ambiente.

IARC-International Agency for Research on Cancer.

IDLH- Immediately Dangerous to Life or Health Concentrations- concentração máxima que uma pessoa pode suportar até trinta minutos caso fique sem proteção contra o agente tóxico sem sofrer danos irreversíveis à saúde.

IUPAC-International Union of Pure and Applied Chemistry.

NASA- United States Aeronautics and Space Agency.

NIOSH- National Institute for Occupational Safety and Health.

NIST- National of Standard and Technology.

$\mathrm{NO}_{\mathbf{x}}$ - Óxidos nitrogenados na forma de gás, especificamente $\mathrm{NO}$ e $\mathrm{NO}_{2}$.

OPAS- Organização Pan-Americana de Saúde.

OSHA- Occupational Safety and Health Administration.

SBS- Sick Building Syndrome- Síndrome do edifício doente.

SED- Síndrome do Edifício Doente

SIM- Select ion monitoring, monitoramento de um íon pelo espectrometro de massas.

USEPA- United States Environmental Protection Agency.

WHO- World Health Organization. 


\section{1- INTRODUÇÃO}

\section{1- Poluição do ar - Poluentes orgânicos}

Desde a Revolução Industrial no século XIX, na Europa e América do Norte, a quantidade de material residual gerado pelas atividades manufatureiras foi aumentando a tal ponto que atualmente são percebidas as consequiências dessas atividades, $\mathrm{O}$ grande perigo representado pelas substâncias orgânicas semi-voláteis no ar se transformou numa evidência para a população no início do século $\mathrm{XX}$ (1915-1918), quando o exército alemão sintetizou as primeiras moléculas cloradas tóxicas utilizando-as como armas químicas. Os numerosos acidentes ocorridos revelaram a falta de domínio destes processos químicos pelos alemães. Isto direcionou, em 1921, o estabelecimento em Porto Dowen na Grã Bretanha um centro de armas químicas. Um grupo de cientistas ficou encarregado de estudar a meteorologia da baixa troposfera e dispersão dos gases e aerossóis no ar.

Devido a isto, foram abertos campos para experimentos direcionados para guerra química, que mais tarde proporcionaram a derivação da equação de difusão usada até os tempos atuais para previsão da dispersão da pluma de gases não reativos (BLOEMEN e BURN, 1995).

A intensa adoção de máscaras usando materiais de carbono para reter poluentes orgânicos tóxicos foi outro ponto positivo advindos desta experiência; o mesmo princípio básico é explorado atualmente para coleta de compostos orgânicos no ar.

A descoberta de Haagen-Smit e Fox (1956) citado por Bloemen e Burn (1995), de que a produção de ozônio era responsável pela então denominada "Los Angeles Smog", e que o smog (smoke + fog, ou seja, fumaça + neblina) era causado pela oxidação fotoquímica de misturas contendo compostos orgânicos e óxidos de nitrogênio $\left(\mathrm{NO}_{\mathrm{x}}\right)$, provaram que as moléculas orgânicas voláteis eram também capazes de causar uma poluição secundária. Subseqüentemente isto acabou esclarecendo que a disseminação do uso de combustíveis fósseis para produção de energia e o aumento na demanda de novos produtos químicos para tornar a vida mais confortável, iria inevitavelmente estar associado com as drásticas mudanças na 
qualidade da atmosfera. Então foram feitos esforços para manter sob controle a emissão de poluentes orgânicos no ar. Para executar estas metas eficientemente, foram feitas pesquisas sobre compostos orgânicos como poluentes do ar. Estas pesquisas foram realizadas para avaliar as emissões, estudar as transformações químicas e físicas que ocorrem no ar, e mensurar a longo e curto prazos os efeitos a saúde humana e meio ambiente.

$\mathrm{O}$ desenvolvimento de ferramentas analíticas foram muito importantes para determinação exata de compostos orgânicos, junto com modelos matemáticos para previsão de concentrações aerométricas de poluentes primários e secundários. Baseado nos resultados destas investigações, os compostos orgânicos foram incluídos numa lista de poluentes de referência, designados para definição da qualidade da atmosfera. Embora o quadro completo de fontes e mecanismos de reação envolvendo estes poluentes não tenha sido bem compreendido ainda, o conhecimento acumulado nos últimos anos tem permitido uma melhor avaliação dos caminhos e interações destes poluentes no ambiente atmosférico e também a identificação de novos efeitos associados com estas emissões. $O$ uso de modelos matemáticos facilitou a compreensão do complexo processo fisico-químico que ocorre no ar, permitindo a previsão a curto e longo prazos de efeitos associados com estas emissões.

\section{2- Estudo dos compostos orgânicos}

Os compostos orgânicos são encontrados no ar de interiores, sendo que nas últimas décadas centenas de substâncias químicas foram identificadas. Embora as ocorrências da maioria das substâncias sejam em concentrações muito baixas, estas possuem relevância quanto ao risco oferecido para a saúde humana. Alguns destes compostos são genotóxicos e até carcinogênicos.

A World Health Organization (WHO), preocupada com os impactos dos poluentes no ar de interiores, tem classificado os compostos orgânicos voláteis como uma das mais importantes classes de poluentes do ar. Os estudos da WHO tem descrito os possiveis efeitos para saúde humana, porém não quanto a informações 
mais detalhadas sobre o efeito total à saúde pública em relação aos poluentes orgânicos no ar de interiores (WHO, 1987). A relutância deste tipo de afirmação reside no grande número de substâncias encontradas, nas variadas concentrações nos ambientes e também na grande variedade de interiores os quais as pessoas ficam expostas. Complementando, a falta de conhecimento dos efeitos adversos para saúde associados com o grande número de compostos aos quais as pessoas são expostas também é fator limitante.

Atualmente, o nivel de atenção tem crescido com relação à poluição do ar de interiores, tanto que o público em geral e os governos tem se voltado para este assunto com especial atenção. Está se tornando cada vez mais necessário combinar o conhecimento adquirido das experiências realizadas com a percepção dos químicos que atuam na área ambiental, com intuito de analisar as fontes e concentrações das espécies químicas encontradas, bem como sua distribuição nos ambientes.

De 23 a 27 de agosto de 1987 se reuniu em Berlin o Working Group on Indoor Air Quality: Organic Pollutants, após a $4^{\text {th }}$ International Conference on Indoor Air Quality and Climate. $\mathrm{O}$ encontro aconteceu com a colaboração do Senado de Berlin, da WHO e do Institute for Water, Soil and Air Hygiene. O evento contou com treze conselheiros de sete países, bem como uma representação da Commission of the European Communities (WHO, 1987). O objetivo deste Grupo de Trabalho foi produzir uma avaliação multidisciplinar do impacto à saúde pública nos correntes níveis de exposição aos poluentes orgânicos em interiores. Para realizar isto, foi necessário consolidar a avaliação dos dados sobre a distribuição da concentração nos vários locais de estudo os quais os compostos orgânicos voláteis foram medidos sistematicamente. Embora estes estudos tenham sido feitos na Alemanha, Itália, Holanda e Estados Unidos com objetivos e protocolos diferentes, isto não invalidou as comparaç̃es entre os resultados. Os químicos ambientais do grupo de trabalho produziram uma sistemática levando em consideração os dados de exposição. Concomitantemente, os toxicologistas, físicos, ambientalistas e epidemiologistas revisaram os dados dos efeitos à saúde pública pelos compostos orgânicos que haviam sido medidos nas várias pesquisas, e apresentados ao grupo de trabalho. 
Esta revisão simultânea produziu várias explicações para os impactos totais à saúde pública, bem como indicou alguns caminhos a serem percorridos para levantamento de informações sobre os impactos.

\section{3- Caracterização dos compostos orgânicos}

Estudos em pequena escala tem indicado que as concentrações de alguns compostos orgânicos no ar de interiores tem excedido os valores encontrados em ambientes externos. Entretanto, os dados foram insuficientes para permitir uma avaliação minuciosa dos níveis de exposição da população.

Nos últimos anos, o conhecimento sobre a ocorrência de compostos orgânicos no ar de interiores tem crescido muito devido ao aumento do número de estudos realizados nos diferentes países. Estudos realizados na Alemanha, Itália, Holanda e Estados Unidos indicaram a presença de vários compostos orgânicos voláteis em concentrações suficientes para estimar a exposição para população em geral (WHO, 1987).

Pesquisas realizadas para determinar as freqüências de distribuição de poluentes do ar de interiores, ou das populações expostas, geralmente não consideram a variação dos poluentes do ar de interiores, mas frações tais como compostos orgânicos "voláteis" ou "semi-voláteis". Desde que se iniciou a diferenciação entre estas frações, a WHO realizou vários estudos para categorizar os variados poluentes do ar encontrados em interiores dividindo-os em quatro grupos como indicado na Tabela 1.

Os grupos ou categorias foram definidos pela variação dos pontos de ebulição, embora não existam limites bem definidos entre as categorias. A razão para esta categorização pode ser definida pelos diferentes métodos de amostragem dos poluentes do ar. A polaridade de algumas substâncias determina a grande distância entre os pontos de ebulição dentro de uma mesma categoria. Devido a este fato também a simples categorização por ponto de ebulição não se aplica a algumas substâncias, pois a reatividade também influencia negativamente nesta categorização. 
Tabela 1- Classificação dos poluentes orgânicos de ambientes interiores

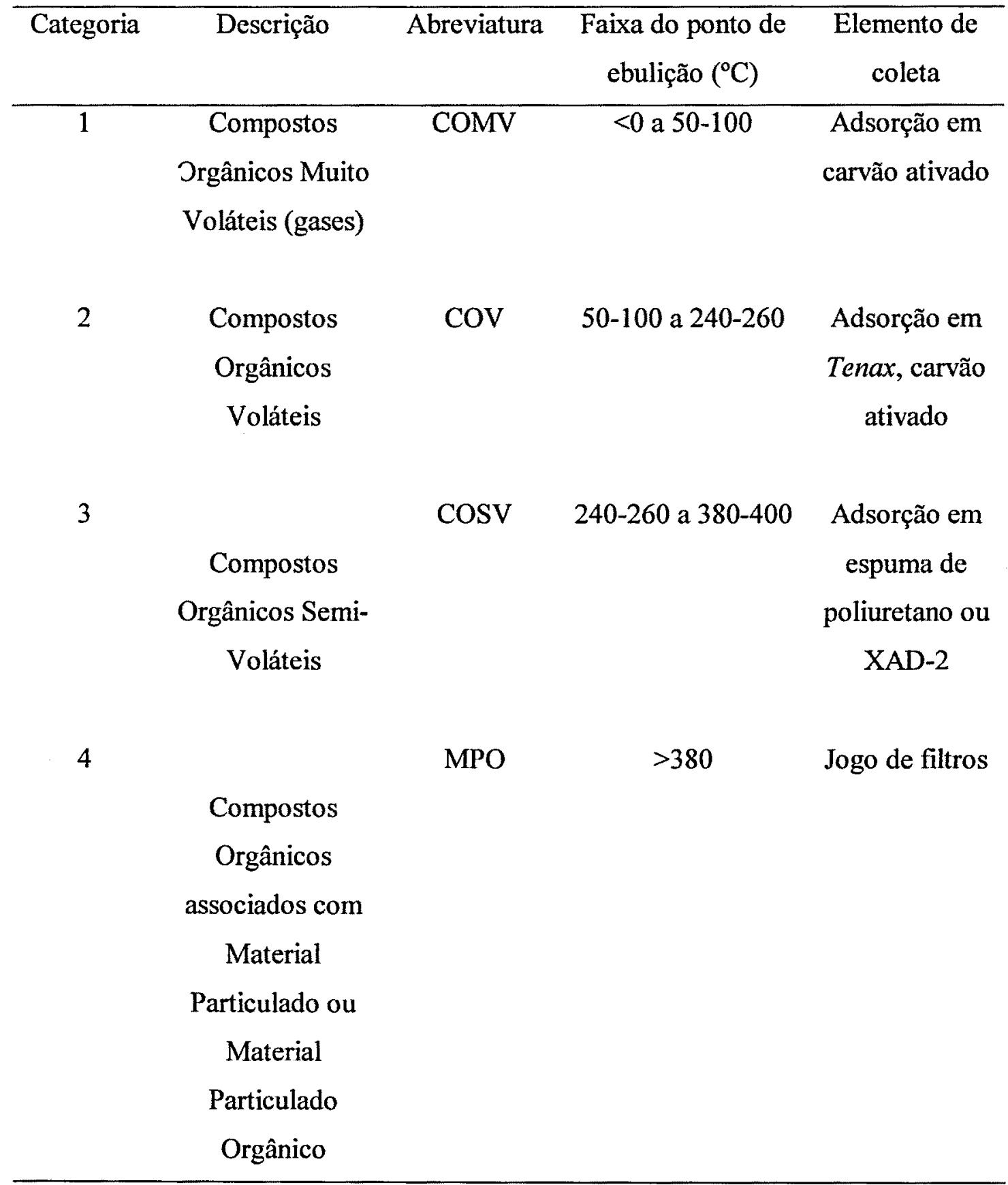

Fonte: WHO, 1987.

\section{4- Ambientes interiores}

Nos últimos anos tem crescido as evidências científicas de que o ar de interiores tem se tornado mais poluído do que o ar externo de cidades 
industrializadas. Pesquisas indicam que as pessoas passam aproximadamente $90 \%$ do seu tempo em interiores (USEPA, 1995). Então para algumas pessoas o ar de certos ambientes pode provocar mais danos à saúde do que o ar externo de cidades reconhecidamente poluídas. Também, pessoas que possam ter se exposto a poluentes de interiores por longos períodos são freqüentemente mais susceptíveis aos efeitos da poluição do ar. Neste grupo incluem-se crianças, idosos e doentes crônicos, especialmente os que sofrem de doenças respiratórias e cardiovasculares.

Enquanto os níveis de poluentes de fontes individuais podem não oferecer risco significante à saúde, muitos ambientes possuem mais do que uma fonte de poluição para o ar interno, sendo que estas fontes emitem seus poluentes simultaneamente dentro do ambiente interno podendo oferecer assim sérios riscos à saúde.

Entende-se por ambientes interiores o interior de: veículos, casas, apartamentos, escritórios, bibliotecas, ou seja, qualquer confinamento a que o ser humano esteja sujeito por um período, seja este longo ou curto, domiciliar, recreativo, ocupacional, comercial, etc..

Estudos da United States Environmental Protection Agency (USEPA), tem encontrado níveis de poluição de várias substâncias orgânicas de 2 a 5 vezes maior em ambientes fechados do que ao ar livre. Durante várias horas imediatamente após certas atividades, como pintura, os níveis chegam a ser 1000 vezes maior em relação ao ambiente externo (USEPA, 1995).

Muitas pessoas trabalham em edifícios com sistema de ventilação e ar condicionado; sendo que estes deveriam ser concebidos para prover ar com temperatura confortável e determinado nível de umidade, livre de concentrações perigosas de poluentes. Porém, alguns tendem a não dedicar a justa atenção ao processo de ventilação necessário ao ambiente. Estes processos tipicamente incluem a entrada de ar externo, condicionamento e mistura com o ar interno, boa distribuição do ar no ambiente e renovação adequada. A qualidade do ar de interiores pode deteriorar quando a manutenção destes processos for inadequada. Por exemplo, dióxido de carbono pode se acumular no ar interior de edifícios sempre que a renovação do ar não for adequada (WHO, 1995). 


\section{5- Fontes de compostos orgânicos voláteis}

Dividem-se em fontes internas e externas, sendo que as internas são influenciadas pelas características dos materiais utilitários, de decoração e de construção.

\subsection{1- Fontes internas de compostos orgânicos voláteis}

A poluição do ar de interiores é causada pelo acúmulo de contaminantes que são primariamente gerados internamente e outros de origem externa, porém em cidades com alto grau de urbanização a predominância dos poluentes do ar de interiores é de origem externa (BRICKUS e AQUINO NETO, 1999). Estes poluentes podem ser gerados por uma fonte específica e limitada ou por várias fontes além de poderem ser gerados periodicamente ou continuamente. Fontes comuns de poluição do ar de interiores incluem tabagismo, materiais de construção, mobilias, equipamentos, materiais de limpeza, máquinas fotocopiadoras, inseticidas, carpetes, tapetes e outras fontes (OSHA, 1994).

Estudos preliminares sobre ambientes internos foram realizados no fim dos anos 70 nos países escandinavos. Mølhave (1982) citado por Bloemen e Burn (1995), demonstrou que alguns materiais de construção comuns, usados em construções escandinavas, emitiam compostos orgânicos. Sufert e Abraham (1982) encontraram níveis altos de benzeno e tolueno associados ao armazenamento de revistas e jornais em casas alemãs.

Segundo a USEPA vários compostos orgânicos voláteis tem sido identificados em ambientes onde o tabagismo é permitido, sendo que $60 \%$ de todas as casas e locais de trabalho nos Estados Unidos estão contaminados inclusive por substâncias carcinogênicas, como o benzeno. A USEPA também verificou que o ar expelido pela respiração dos fumantes continha dez vezes mais benzeno quando comparado com não fumantes. A quantidade de benzeno estava relacionada diretamente com a quantidade de alcatrão e de nicotina presentes no cigarro. Outra fonte de emissão importante nos EUA é a queima de combustíveis em interiores, 
como aquecedores a querosene e fornos a lenha, que podem emitir tanto compostos orgânicos voláteis como semi-voláteis (USEPA, 1994).

Knöppel e Schauenburg (1987) citados por Bloemen e Burn (1995), estudaram emissões de produtos de uso doméstico (detergentes, ceras, lustra-móveis) encontrando: alcanos, alcenos, álcoois, ésteres e terpenos.

Girman e Hodgson (1987) em estudos realizados câmaras, com removedores de tinta residenciais, encontraram concentrações altas de cloreto de metileno nas situações mais realísticas (BLOEMEN e BURN,1995).

A United States National Aeronautics and Space Agency (NASA) mediu emissões orgânicas de 5000 materiais ou produtos usados em missões espaciais. Em torno de 3000 destes materiais ou produtos estão no comércio para uso do público em geral. As principais substâncias químicas emitidas pelos materiais ou produtos testados, em ordem de abundância, foram: tolueno, em 1896 materiais ou produtos, metiletilcetona, em 1261 e xilenos em 1111 (BLOEMEN e BURN,1995).

Um estudo de 41 dias foi realizado por Berglund (1987) em conjunto com a American Society of Heating, Refrigerating and Air-Conditioning Engineers (ASHRAE) utilizando uma câmara com materiais de construção pertencentes a uma pré-escola antiga. Este estudo indicou que os materiais tinham absorvido cerca de 30 compostos orgânicos voláteis os quais foram reemitidos na câmara nos 30 primeiros dias do estudo, porém apenas 13 dos compostos orgânicos voláteis originalmente presentes continuaram a ser emitidos até o final, indicando que apenas estes compostos orgânicos voláteis pertenciam aos materiais e não eram fruto de outras fontes (BLOEMEN e BURN, 1995).

Outro estudo, feito por Seifert e Schmahl (1987), citados por Bloemen e Burn (1995), sobre adsorção de compostos orgânicos voláteis e compostos orgânicos semivoláteis em materiais como: madeira compensada e têxteis, concluiu que a adsorção de compostos orgânicos voláteis foi relativamente pequena. Estudos da USEPA indicam que são altas as variações de emissões de várias substâncias químicas para materiais usados. Para materiais de base líquida tais como: tintas e adesivos, a maioria dos compostos orgânicos voláteis pode ser emitida nas primeiras horas ou nos primeiros dias de aplicação. Outros estudos da USEPA em construções novas indicaram que as concentrações de 8 das 32 substâncias químicas medidas nos dias 
imediatamente após o término da construção, eram cem vezes maiores se comparadas com o ambiente externo; as substâncias mais abundantes encontradas foram: xilenos, etilbenzeno, etiltolueno, trimetilbenzeno, decano e undecano. $O$ tempo de permanência destas substâncias no interior dos ambientes variaram de 2 a 6 semanas (USEPA,1994). Novas construções podem levar até 6 meses para que as concentrações de compostos orgânicos voláteis diminuam chegando assim ao nível de edifício antigo. Para materiais de construção secos tais como: carpetes e produtos de madeira prensada, as emissões são continuadas, porém com nível baixo por longos períodos. $\mathrm{O}$ formaldeído liberado de produtos da madeira prensada podem ser emitidos vagarosamente com tempo de permanência de vários anos (WHO,1986).

De acordo com estudos recentes, o 4-fenilciclohexeno (4-PC), um produto de reação do butadieno-estireno contido nos carpetes, é o principal composto orgânico volátil emitido dos carpetes após os primeiros dias de fabricação. Esta substância é a responsável pelo odor característico de carpete novo.

As principais categorias de substâncias tóxicas no tocante a exposição humana são: desodorantes de banheiros e sprays para odorização de ambientes. Sendo uma das funções destes produtos também a persistência no ambiente, estes ficam por semanas nos ambientes. A maior parte dos compostos orgânicos voláteis utilizados nestes produtos são: $p$-diclorobenzeno, limoneno e o $\alpha$-pineno. $O$ limoneno (essência de limão) e o $\alpha$-pineno (essência de pinho) também estão presentes em alguns materiais de limpeza. Também é crescente o uso destes produtos no Brasil (BRICKUS e AQUINO NETO, 1999)

Nos Estados Unidos, em 1991 a USEPA declarou que era conhecido o efeito carcinogênico da fumaça do cigarro (BLOEMEN E BURN,1995).

Três grandes estudos de compostos orgânicos voláteis, envolvendo de 300 a 800 casas, foram feitos na Holanda por Lebret (1986), na Alemanha por Krause (1987) e nos Estados Unidos por Wallace (1987). Outro estudo também foi feito no nordeste da Itália, em 15 casas, por De Bortoli (1986) todos citados em WHO (1989). Foram observadas concentrações notavelmente similares para maioria dos orgânicos, indicando fontes de compostos orgânicos voláteis similares nestes países. Uma exceção foi o clorofórmio, muito encontrado nos Estados Unidos na faixa de 1 a 4 
$\mu \mathrm{g} / \mathrm{m}^{3}$, mas não encontrado na Europa. Isto era esperado devido ao fato de que a cloração da água é utilizada nos Estados Unidos, mas não na Holanda e Alemanha. Pontos relevantes destes estudos:

- Níveis encontrados dentro das casas e edifícios antigos ( $>1$ ano de construção) são, em vários casos, maiores do que os níveis de ambientes externos.

- Edifícios novos (<1 mês de construção) apresentam concentrações de compostos orgânicos voláteis (alifáticos e aromáticos) cem vezes maiores que ambientes externos, caindo para 10 vezes após 2 a 3 meses do término da construção, no que se refere à emissão proveniente de tintas e adesivos.

- Mais de 500 compostos orgânicos voláteis foram identificados em quatro edifícios em Washington, DC (WHO, 1987).

A Tabela 2 descreve os compostos orgânicos voláteis mais encontrados em pesquisas no ar de interiores na Europa e Estados Unidos.

A Tabela 3 mostra as quantidades de compostos orgânicos voláteis que podem estar sendo liberados para os ambientes interiores. 
Tabela 2- Compostos orgânicos voláteis mais freqüentes em interiores e suas fontes

Composto

Principais fontes de emissão

Acetona

cosméticos

Álcoois

álcool de limpeza, agentes de

limpeza

Aromáticos (tolueno, xilenos, etilbenzeno,

Trimetilbenzenos)

tintas, adesivos, gasolina, combustão

Alifáticos (octano, decano, undecano)

tintas, adesivos, gasolina, combustão

Benzeno

fumaça de cigarro, escapamento

de veículos

Tetracloreto de carbono

fungicidas, inseticidas

Clorofórmio

chuva torrencial, produtos

utilizados em lava-louças e em

lava-roupas, produtos de limpeza

p-diclorobenzeno

desodorantes de ambientes,

naftalina

Formaldeído

madeira prensada

Cloreto de metileno

solventes de tinta e tintas

Estireno

fumaça de cigarro

Tetracloroetileno

roupas lavadas a seco

1,1,1 tricloroetano

roupas lavadas a seco $\mathrm{e}$

aerossóis

Tricloroetileno

cosméticos, partes eletrônicas,

Terpenos

bebidas, desodorizantes

perfumados, tecidos, fumaça de

cigarro, alimentos, betume

Fonte: Bloemen e Burn, 1995. 
Tabela 3 - Fatores de emissão ( $\mu \mathrm{g} / \mathrm{m}^{2}$ de superficie/hora) para alguns materiais que emitem vapores orgânicos

\begin{tabular}{|c|c|c|}
\hline Material & Substância emitida & Fator de Emissão \\
\hline \multirow{9}{*}{$\begin{array}{l}\text { PRODUTOS DE MADEIRA } \\
\text { PRENSADA }\end{array}$} & Acetona & $28,9-47,2$ \\
\hline & Propanol 2 & $2,8-9,4$ \\
\hline & Butanol 2 & $1,3-3,9$ \\
\hline & Hexanol & $10,2-30,2$ \\
\hline & Benzaldeído & $8,8-19,1$ \\
\hline & Benzeno & $3,4-8,1$ \\
\hline & $\begin{array}{l}\text { Alifáticos e alifáticos } \\
\text { oxigenados }\end{array}$ & 27 \\
\hline & Aromáticos & 1,1 \\
\hline & Halogenados & 0,14 \\
\hline \multicolumn{3}{|c|}{ MATERIAIS DE CONSTRUÇÃO, MOBILLIA E PRODUTOS DOMÉSTICOS. } \\
\hline Adesivos & \multirow{6}{*}{$\begin{array}{l}\text { Compostos alifáticos, alifáticos } \\
\text { oxigenados, aromáticos } \\
\text { halogenados }\end{array}$} & $>5000$ \\
\hline Látex de calafetação & & 637 \\
\hline Tinta látex & & 249 \\
\hline Adesivo de carpete & & 234 \\
\hline Borracha preta de molde & & 103 \\
\hline $\begin{array}{l}\text { Cabo de telefone, molde de } \\
\text { vinil, carpete }\end{array}$ & & $30-60$ \\
\hline \multirow[t]{3}{*}{ Tintas em geral } & Benzeno & $120 \pm 29$ \\
\hline & 1,1,1-tricloroetano & $31 \pm 15$ \\
\hline & n-undecano & $1.500 \pm 350$ \\
\hline \multirow{6}{*}{$\begin{array}{l}\text { Cola de papel de parede } \mathrm{e} \\
\text { carpete }\end{array}$} & 1,2-dicloroetano & $180-310$ \\
\hline & 1,1,1-tricloroetano & $84-260$ \\
\hline & Etilbenzeno & nd -77 \\
\hline & p-xileno & $26-150$ \\
\hline & n-decano & $190-545$ \\
\hline & n-undecano & $300-500$ \\
\hline \multirow{3}{*}{$\begin{array}{l}\text { Materiais de limpeza e } \\
\text { inseticidas }\end{array}$} & Clorofórmio & $15.000 \pm 250$ \\
\hline & 1,1,1-tricloroetano & $37.000 \pm 15.000$ \\
\hline & Tetracloreto de carbono & $71.000 \pm 5.300$ \\
\hline Naftalina & p-diclorobenzeno & $1.050-5.900^{*}$ \\
\hline
\end{tabular}

${ }^{*}$ Emissão em $\mathrm{mg} / \mathrm{cm}^{2}$

Fonte: Cralley, 1990.

\subsection{2- Fontes de compostos orgânicos voláteis em ambientes externos}

Nos ambientes externos, os compostos orgânicos voláteis mais comuns são encontrados em áreas com grande número de indústrias e com denso tráfego de veículos, sendo que os niveis destes compostos no ar chegam a ser inferiores que os de interiores, em determinados casos (USEPA, 1994).

Nos Estados Unidos o Clean Air Act de 1990 exigiu que a USEPA inserisse no National Ambient Air Quality Standards - NAAQS vários compostos químicos 
para regulamentação naquele país como poluentes do ar externo, mas produtos como pesticidas e solventes demonstraram ser mais agressivos e persistentes em interiores.

Para alguns hidrocarbonetos, a principal fonte externa é a evaporação de gasolina ou os gases de escapamento dos veículos. Dependendo do tipo de veículo, a evaporação de certos compostos aromáticos como: benzeno, xilenos, tolueno e etilbenzeno, pode ser até seis vezes maior no interior do veículo devido à posição do tanque de combustível e seu isolamento (BLOEMEN e BURN, 1995).

No entanto, as fontes de compostos orgânicos voláteis são muito variadas, tanto em interiores como em ambientes externos. Torna-se assim importante, em pesquisas relacionadas ao ar de interiores, verificar se determinado composto orgânico volátil não possui como sua fonte principal o ambiente externo. Um exemplo disto pode ser a detecção de um composto orgânico volátil proveniente de solventes de tintas. Pode-se ter como fonte a própria parede do ambiente interior, mas se o edifício teve suas paredes externas recém pintadas, provavelmente este fato pode influenciar nos resultados obtidos.

A Região Metropolitana de São Paulo - RMSP, possui denso tráfego de veículos, sendo que, segundo dados de 2001 da Companhia de Tecnologia de Saneamento Ambiental - CETESB, sobre a qualidade do ar em São Paulo, indicaram que os automóveis participaram com a emissão de 395 mil toneladas por ano de hidrocarbonetos totais, o equivalente a $96 \%$ da emissão destes compostos para a atmosfera, enquanto que os processos industriais participaram com 12 mil toneladas por ano (CETESB, 2002). Os compostos orgânicos voláteis estão contidos nos hidrocarbonetos totais. No centro de São Paulo a participação dos veículos deve ser maior ainda, ou seja, próxima a $100 \%$ das emissões de hidrocarbonetos totais, já que a presença de emissões industriais na região é pouco significativa.

Segundo a CETESB, no cálculo total da emissão de hidrocarbonetos não é considerado somente o lançamento proveniente da queima de combustíveis, mas também a evaporação dos combustíveis dentro do sistema de alimentação dos veículos e da estocagem e venda nos postos e distribuidoras de combustível (CETESB, 2002).

Colón e col. (2001) reportou dados sobre compostos orgânicos voláteis em estudo realizado no ar externo da cidade de São Paulo em novembro de 1998. A 
Tabela 4 mostra os resultados das análises para alguns compostos aromáticos cuja amostragem foi feita por tubos amostradores, bem como de medições feitas em Los Angeles, reportadas por Colón e Col (2001). A estação Cerqueira César encontra-se relativamente próxima da área objeto do estudo desta Tese e a região desta Estação caracteriza-se também por ter contribuição tipicamente de emissões veículos. Os dados desta Tabela 4 mostram que as concentrações na cidade de São Paulo e também especificamente na estação Cerqueira César são mais altas que as de Los Angeles, cidade onde a contribuição das emissões veiculares é também muito alta.

Tabela 4 - Concentrações médias (ppb em volume) de alguns compostos orgânicos voláteis no ar da cidade de São Paulo, em novembro de 1998, obtidas com tubos amostradores e de estudo em Los Angeles, feito por Lonneman.

\begin{tabular}{lccc}
\hline Composto Orgânico Volátil & $\begin{array}{c}\text { Média de 6 estações } \\
\text { em São Paulo }\end{array}$ & $\begin{array}{c}\text { Estação } \\
\text { Cerqueira César }\end{array}$ & $\begin{array}{c}\text { Los Angeles } \\
\text { (EUA) }\end{array}$ \\
\hline Benzeno & 2,5 & 3,5 & 1,7 \\
Tolueno & 15,1 & 11,9 & 5,1 \\
Etilbenzeno & 3,5 & 2,3 & 0,7 \\
m,p - xileno & 7,8 & 5,3 & 2,6 \\
o-xileno & 2,4 & 2,0 & 0,9 \\
1,3,5- trimetil benzeno & 0,7 & 0,7 & 0,4 \\
1,2,4-trimetil benzeno & 2,3 & 2,6 & 0,9 \\
\hline
\end{tabular}

Fonte: Colón e col. (2001)

\section{6- Efeitos sobre a saúde}

Os efeitos provocados por compostos orgânicos voláteis cobrem uma grande diversidade de respostas variáveis provenientes de efeitos indesejáveis como odores e irritações, através de efeitos tóxicos que modificam ou interferem no funcionamento normal de órgãos ou tecidos. Estes efeitos possuem características que variam com o tempo, no início existe a percepção aguda do odor, mas logo o organismo chega a adaptação, tendo por conseqüência uma ação irritante que 
aumenta devido a exposição prolongada, chegando até à manifestação de efeitos de genotoxicidade, o seja, a capacidade de modificar a informação genética, devido ao acúmulo do poluente no organismo (WHO, 1987).

Quanto aos efeitos sensoriais, estes possuem uma concentração limite que abaixo desta o organismo não percebe efeito algum, e isto também ocorre para a toxicidade que afeta sistemas de órgãos e tecidos, mas geralmente é aceito que os efeitos genotóxicos não possuem tais limiares (WHO, 1987).

\subsection{1- Efeitos agudos dos compostos orgânicos voláteis}

Os principais efeitos agudos relacionados aos compostos orgânicos voláteis vão de irritação sensorial a efeitos comportamentais, neurotóxicos, hepatotóxicos e genotóxicos. As concentrações nas quais estes efeitos ocorrem são usualmente muito maiores do que aquelas observadas no ar de interiores. Exposição a misturas de compostos orgânicos voláteis pode ser uma importante causa da Síndrome do Edifício Doente (WHO, 1999).

Os possiveis efeitos agudos dos compostos orgânicos voláteis em geral incluem irritação nos olhos, nariz e garganta, danos ao sistema nervoso central, dores de cabeça e lapsos de memória. Estes sintomas são facilmente observados em pessoas que convivem em construções novas ou em edificios recém reformados (WHO,1997). Desconforto, lacrimejação, espirro, tosse, náusea e dispnéia também tem sido observados, dependendo da concentração de formaldeído no ambiente (WHO, 1999).

Alguns efeitos agudos tem a possibilidade de estarem relacionados com a Síndrome do Edifício Doente - SED (Sick Building Syndrome - SBS), podendo ser relacionada com sintomas que afetam os ocupantes de edificios, sendo que estes diminuem quando os ocupantes se ausentam do edificio. Estes sintomas não são correlacionados exatamente com poluentes específicos ou fontes de poluição dentro do edificio (OSHA,1994). Segundo a definição da WHO em 1983, esta síndrome está relacionada com a redução da produtividade do trabalhador sendo que um edifício é classificado como doente quando o número de trabalhadores com reclamações de mal-estar ultrapassa $20 \%$. 
Um comitê da WHO em 1984 sugeriu que mais de $30 \%$ dos edifícios novos e reformados no mundo podem ser objeto de reclamações relacionadas com a qualidade do ar de interiores. Freqüentemente estas condições são temporárias, mas alguns edifícios ficam com problemas por longo tempo. Algumas vezes os problemas com ar de interiores resultam de um péssimo projeto do edifício ou atividades inadequadas pelos seus ocupantes.

Alguns fatores que contribuem para esta síndrome são:

Ventilação inadequada: até a metade do Século 20 (ou Século XX), o padrão de ventilação para edifícios era de aproximadamente de 15 pés cúbicos por minuto $\left(25,5 \mathrm{~m}^{3} /\right.$ hora $)$ de ar externo para cada ocupante do edifício, com função primordial de diluir ou remover odores corporais. Como resultado da crise do petróleo em 1973, ocorreram medidas de conservação de energia nos Estados Unidos, resultando em uma redução da quantidade de ar de renovação para 5 pés cúbicos por minuto $\left(8,5 \mathrm{~m}^{3} / \mathrm{hora}\right)$ por ocupante. Em alguns casos esta redução demonstrou ser inadequada para a saúde de algumas pessoas expostas. A ventilação inadequada aliada ao aquecimento interno dos edificios e sistemas de distribuição de ar mal projetados poderia estar correlacionada com a síndrome. Em um esforço para alcançar um nível aceitável de qualidade do ar com economia de energia, a ASHRAE revisou os padrões de ventilação para retornando ao mínimo de 15 pés cúbicos por minuto de ar externo por pessoa ( 20 pés cúbicos por minuto em escritórios). Pode-se requerer um valor superior a 60 pés cúbicos por minuto para alguns espaços (como locais com fumantes) dependendo das atividades realizadas conforme determinação da norma ASHRAE 62-1989 (USEPA, 1995);

* Presença de poluentes químicos provenientes de fontes internas: São exemplos de fontes internas: adesivos, carpetes, tapeçaria, produtos manufaturados de madeira, máquinas copiadoras, pesticidas e produtos de limpeza, que podem emitir compostos orgânicos voláteis, incluindo formaldeído. O tabagismo pode contribuir de forma razoável para aumento do nível de compostos orgânicos voláteis como, por exemplo, o benzeno, também com outras substâncias tóxicas e material particulado respirável. 
Presença de poluentes químicos vindos de fontes externas: o ar externo que entra em um edificio é uma fonte de poluição. Por exemplo, poluentes provenientes da exaustão de motores de automóveis, respiros de encanamentos de instalações sanitárias e da exaustão de banheiros e cozinhas podem penetrar em edifícios nos casos de captação de ar mal localizadas, janelas e outras aberturas. Também, produtos de combustão podem penetrar em edificios próximos a garagens.

- Presença de contaminantes biológicos: bactérias, pólen e vírus são tipos de contaminantes biológicos. Estes contaminantes podem ser originários de água estagnada que se acumula em dutos, umidificadores e drenos ou em lugares onde a água seja coletada. Insetos ou pássaros podem também ser fontes de contaminação biológica. Sintomas fisicos como tosse, dores no tórax, febre, arrepios constantes, dores musculares, alergias resultando em irritações nas membranas mucosas e congestionamento nas vias respiratórias podem ser relacionados com a contaminação biológica. Uma bactéria encontrada em ambiente interno, a Legionella, é a causa da doença do legionário que afeta indivíduos com deficiência imunitária e da febre Pontiac que é semelhante à gripe, porém em indivíduos sadios, sendo que estas doenças ocorrem como um tipo de pneumonia (WHO,1994). Segundo citado por Petillo (2002), a denominação de "doença do legionário" se deve ao surto de pneumonia que afetou pessoas da região circunvizinha de um hotel na cidade de Filadélfia na década de 1970. A doença afetou primeiramente os participantes da convenção anual da Legião Americana em 1976 e foi provocada por uma bactéria até então desconhecida, que encontrou no sistema de ventilação do hotel condições propícias para o seu desenvolvimento e ainda, um grupo de indivíduos com imunodeficiência senil, chegando a provocar óbitos.

Embora a causa ou causas da Síndrome do Edifício Doente não sejam perfeitamente definidas, os compostos orgânicos voláteis sempre estão sob suspeita. Estudos de laboratório mostraram que certos sintomas (dores de cabeça e irritação dos olhos) podem ser produzidos por compostos orgânicos voláteis em concentrações de 5 a $25 \mathrm{mg} / \mathrm{m}^{3}$, enquanto medições indicam que os níveis de compostos orgânicos voláteis não excedem 1 a $2 \mathrm{mg} / \mathrm{m}^{3}$ nos edifícios doentes (WHO, 1997). 
Em quatro estudos europeus e um estudo americano foram ministrados questionários a milhares de trabalhadores de escritórios na tentativa de aprender mais sobre queixas relacionadas a saúde e o edifício de trabalho. Os estudos europeus foram realizados por: na Grã-Bretanha por Wilson e Hedge (1987), na Dinamarca por Slov (1989), na Suécia por Stenberg (1990) e na Holanda por Preller (1990), todos citados por Bloemen e Burn (1995). O estudo dos Estados Unidos foi feito na cidade de Washington. Todos os estudos europeus envolveram um grande número de edifícios (28 a 61 edifícios), ao passo que o estudo americano envolveu apenas quatro. Os pesquisadores europeus puderam comparar, por exemplo, construções com ventilação natural e construções com ventilação mecânica. Por outro lado, o estudo americano envolveu muito mais funcionários do que os europeus; sendo possível testar o efeito sobre uma população maior, bem como o efeito das emissões dos carpetes novos em dois edifícios. Slov (1989) também fez um censo com 4.369 funcionários em 28 edifícios. Numa comparação direta das frequeências dos sintomas nestes casos foi considerado muito difícil face aos diferentes critérios adotados para os sintomas; o critério mínimo para uma resposta positiva, variou de dois dias por ano no estudo britânico e cerca de cem dias por ano para o estudo dinamarquês.

No estudo americano, 2 dos 4 edifícios estudados tinham carpetes novos, sendo que 100 pessoas ficaram doentes com sintomas relacionados a este item conforme citado por Bloemen e Burn (1995). No início estes sintomas pareciam relacionados provavelmente com as emissões de compostos orgânicos voláteis do carpete novo ou do adesivo, embora exista a possibilidade do carpete antigo ter liberado esporos e estes causarem reações alérgicas. Neste estudo americano foi investigado o efeito à saúde de pessoas em áreas com carpete novo, e encontrou-se apenas sintomas relacionados com a garganta como: secura, inflamação e rouquidão, sendo que estes são típicos para carpetes novos.

Embora os sintomas da SED sejam freqüentemente de menor intensidade, eles podem ser um fator de peso na redução da produtividade. Por exemplo, no estudo dos Estados Unidos, metade dos 4.000 funcionários que responderam ao questionário citaram dor de cabeça de um a dois dias por semana. Contabilizando, apenas em termos numéricos, tem-se até cerca de 200.000 dores de cabeça por ano. Se cada dor de cabeça causar dez minutos de perda de tempo no trabalho, isto gera 
em torno de quatro anos-homem de perda de tempo. Hall (1992) em seu trabalho citado por USEPA (1994) mensurou como ser de US\$ 8,00 o valor para uma dor de cabeça não freqüente. Estes valores, se considerarmos 4.000 trabalhadores como força de trabalho, pode-se chegar a US\$ $32.000,00$ que corresponde a uma perda de 10 a 15 homens-ano de trabalho. Dores de cabeça foram citadas em 16\% dos casos, no estudo dos Estados Unidos, e outros sintomas como febre, resfriados, gripes foram apenas de 2 a $3 \%$.

No Brasil, foi realizado por Petillo (2002) um estudo específico sobre desinfetantes de uso geral em interiores (instalações sanitárias), onde se constatou até $49 \mathrm{mg} / \mathrm{m}^{3}$ de formaldeído no ar, tendo sido inclusive necessário o uso de protetor respiratório para realizar as amostragens. Também neste mesmo estudo se constatou incompatibilidade na legislação sanitária brasileira, do Ministério da Saúde, Portaria MS $N^{\circ} 15 / 1988$, que permite o uso de qualquer concentração de formaldeído em desinfetantes de uso geral doméstico e profissional, sendo que deste mesmo Ministério tem-se a Resolução ANVISA $n^{\circ}$ 9/2003, que recomenda não utilizar produtos que contenham formaldeído em ambientes de uso público e coletivo.

As doenças relacionadas com o edifício também conhecidas como Buildingrelated Illnesses (BRI), que podem ser correlacionadas com um poluente especifico ou fonte poluidora de um edifício (OSHA, 1994), também podem ser correlacionadas com efeitos agudos provocados por compostos orgânicos voláteis.

Algumas características indicam a ocorrência destas doenças: ocupantes do edifício apresentam sintomas como tosse, dores no tórax, febre, arrepios constantes e dores musculares; os sintomas podem ser clinicamente definidos e possuem causas claras; os queixosos podem ter recuperação demorada após deixar o edifício (WHO, 1994).

Em São Paulo verificou-se também, em estudo realizado em 1994 (ASSUNÇÃO, 1997), alguns sintomas relacionados com o edifício, como: dor de cabeça, tosse, resfriado, dores no corpo, entre outros. Este estudo especificamente foi realizado em um escritório climatizado na região da Avenida Paulista. 


\subsection{2- Efeitos crônicos}

Estes efeitos estão relacionados com a exposição prolongada a substâncias tóxicas, mas a relação causa-efeito não é facilmente estabelecida. A proteção contra estas exposições se faz através dos seguintes passos: identificação da fonte, levantamento do risco e gerenciamento ou redução do risco. Em contraste com outros efeitos tóxicos, não há concentração limiar para substâncias com potencial de genotoxicidade ou de carcinogenicidade o que torna ainda mais difícil o seu controle (WHO, 1999).

Genericamente são três as formas para identificação do risco: estudos epidemiológicos de populações humanas, estudos toxicológicos usando animais como cobaias e testes de laboratório in vitro.

Os testes de laboratório in vitro indicam o potencial de mutagenicidade, os testes em animais determinam o potencial carcinogênico em organismos vivos, e estudos epidemiológicos humanos determinam a força da associação entre a exposição ao poluente ou poluentes com relação à ocorrência de câncer. A maioria das avaliações do potencial de carcinogênese e os modelos matemáticos são baseadas em testes com animais (WHO,1987). Atualmente, os métodos para avaliar o risco de carcinogênese são considerados insatisfatórios.

Existe um método que utiliza os resultados de estudos de longo prazo estabelecendo o potencial carcinogênico de um dado produto químico, e então extrapola os resultados de animais para o homem, considerando também extrapolação de altas doses para baixas doses, assumindo que não há desvio Estes tipos de extrapolações são os pontos fracos do método. Por exemplo, uma espécie pode ser metabolicamente diferente de outra, ou pode ter um mecanismo melhor de reparação de DNA, o qual indica um efetivo desvio. (WHO,1987).

Um segundo método utiliza um animal para estudo de toxicidade de curto prazo e a partir do resultado procura estimar o potencial carcinogênico. Este é baseado na premissa que toxicidade é correlata à carcinogenicidade. Se esta premissa for considerada como totalmente verdadeira, muitas substâncias químicas poderão ser consideradas carcinogênicas, sem que se realizem testes de carcinogenicidade (BLOEMEN e BURN, 1995). 
Nos Estados Unidos, o primeiro método padronizado empregado foi o da USEPA, que estima os limites superiores para potenciais de carcinogênese de mais de 50 substâncias, incluindo os compostos orgânicos voláteis. Sendo que este método seleciona o ponto mais expressivo dentre vários pontos e apenas os resultados das espécies de animais mais sensíveis são usadas para extrapolação para humanos; o resultado é considerado super estimado - o potencial verdadeiro pode não ser tão grande, ou seja, o valor pode ser bem inferior. Esta é a falha do método, ele não estima o valor "melhor", apenas o valor do limite superior, sendo que todas essas avaliações dependem dos resultados de uma equipe de estudo para estimar a população exposta, eles tendem a concordar que os compostos orgânicos voláteis como: benzeno e clorofórmio oferecem alto risco à saúde da população.

$\mathrm{Na}$ mais recente estimativa de risco (BLOEMEN e BURN, 1995), seis compostos orgânicos voláteis: benzeno , cloreto de vinilideno , p-diclorobenzeno , clorofórmio , cloreto de metileno e tetracloreto de carbono excederam por um fator de dez o risco mínimo aceitável ou seja o nível de $10^{-6}$, ou seja uma chance em um milhão em desenvolver câncer.

A International Agency for Research on Cancer (IARC) classifica as substâncias químicas de acordo com a evidência de carcinogenicidade relativas a literatura mundial. Os grupos reconhecidos são:

Grupo 1- $\mathrm{O}$ agente é carcinogênico para humanos (evidências suficientes de carcinogenicidade em humanos).

Grupo 2A- $\mathrm{O}$ agente é provavelmente carcinogênico para humanos (evidências limitadas de carcinogenicidade em humanos e suficientes evidências em experiências com animais).

Grupo 2B- $\mathrm{O}$ agente pode vir a ser carcinogênico para humanos (evidências inadequadas de carcinogenicidade em humanos, mas suficiente em animais, ou evidências limitadas em humanos e insuficientes em animais).

Grupo 3- $O$ agente não pode ser classificado como carcinogênico para humanos.

Grupo 4- $O$ agente não é provavelmente carcinogênico para humanos (evidências indicam que não é carcinogênico em animais). 
Diferentes paises utilizam a classificação da IARC para identificar carcinogênese em humanos com fins de regulamentação, e cada país a interpreta de sua forma dando um significado particular a sua classificação. Os compostos identificados na Tabela 5 possuem grau de consistência nas diversas pesquisas realizadas em âmbito mundial. Estas substâncias são consideradas possuidoras de propriedades genotóxicas e/ou carcinogênicas citadas por Bloemen e Burn (1995).

Os efeitos genotóxicos podem ser avaliados diretamente pelo estudo nos efeitos em animais ou em seus descendentes. Como por exemplo observar anomalias cromossômicas. 
Tabela 5- Parâmetros de carcinogenicidade de poluentes do ar de interiores

\begin{tabular}{|c|c|c|c|c|c|c|}
\hline \multirow[b]{2}{*}{ Composto } & \multirow[b]{2}{*}{$\begin{array}{l}\text { Classificação } \\
\text { IARC }\end{array}$} & \multirow[b]{2}{*}{$\begin{array}{l}\text { Unidade } \\
\text { de risco }\end{array}$} & \multicolumn{3}{|c|}{ Exposição de $1 \mu \mathrm{g} / \mathrm{m}^{3}$} & \multirow[b]{2}{*}{ Base do risco de câncer } \\
\hline & & & $\begin{array}{l}10^{\circ} \\
\text { percentil }\end{array}$ & $\begin{array}{l}50^{\circ} \\
\text { percentil }\end{array}$ & $\begin{array}{l}90^{\circ} \\
\text { percentil }\end{array}$ & \\
\hline Benzeno & 1 & 4.0 & 2 & 10 & 20 & estudos epidemiológicos humanos \\
\hline Tetraclorometano & $2 \mathrm{~B}$ & 15.0 & -- & 1 & 20 & extrapolação com testes de animais \\
\hline Clorofórmio & $2 \mathrm{~B}$ & 10.0 & - & 3 & 15 & extrapolação com testes de animais \\
\hline 1,2 dicloroetano & $2 \mathrm{~B}$ & 26.0 & -- & -- & -- & extrapolação com testes de animais \\
\hline tricloroetileno & $2 \mathrm{~B}$ & 3.1 & 1 & 5 & 20 & extrapolação com testes de animais \\
\hline
\end{tabular}

\# Risco de câncer por milhão de pessoas para vida toda, por exposição a $1 \mu \mathrm{g} / \mathrm{m}^{3}$.

Fonte: WHO,1987. 


\section{7- Benzeno, tolueno e hidrocarbonetos clorados leves}

Verifica-se pela classificação da IARC, que o benzeno é considerado como carcinogênico para humanos (grupo 1). Por esta mesma classificação o clorofórmio, tetraclorometano (tetracloreto de carbono), 1,2-diclorometano e o tricloroetileno, todas estas substâncias com menos de quatro carbonos na cadeia e todas cloradas (hidrocarbonetos halogenados), foram consideradas carcinogênicas para animais (grupo 2B). O benzeno é também a única substância com estudos epidemiológicos humanos demonstrando a possível influência dos níveis ambientais de exposição no risco de câncer; dois estudos demonstraram que crianças de mães fumantes morrem de leucemia duas vezes mais que crianças de mães não fumantes. A proporção maior de mortalidade é consistente com níveis elevados de benzeno no ar expelido pelos fumantes (BLOEMEN e BURN,1985).

Para a American Conference of Governmental Industrial Hygienists (ACGIH) o benzeno é considerado classe $\mathrm{A} 1$, ou seja, carcinogênico para humanos.

O clorofórmio e o tetracloreto de carbono, como mostrado na Tabela 3, são encontrados em inseticidas e produtos de limpeza, contribuindo-para a poluição de interiores. Não obstante, também foram classificados como $2 \mathrm{~B}$ na escala da IARC. Além disso, segundo a ACGIH estes agentes tóxicos clorados são considerados classe A2 - suspeitos de serem carcinogênicos para humanos.

Portanto, estas três substâncias: benzeno, clorofórmio e tetracloreto de carbono, oferecem iminente risco à população que se expõe em interiores contaminados por estes agentes tóxicos.

\subsection{1- Toxicidade}

Toxicidade é a propriedade característica dos agentes, como por exemplo, o benzeno, tolueno e substâncias cloradas, de promoverem efeitos nocivos às estruturas biológicas, através de interações fisico-químicas (OGA, 1996). 
$\mathrm{Na}$ seqüência, são descritas as principais características toxicológicas do benzeno, tolueno, clorofórmio e tetracloreto de carbono, substâncias essas de interesse na verificação do ar de interiores devido suas caracteristicas nocivas.

\subsubsection{1- Benzeno}

As principais vias de absorção do benzeno são a respiratória e a cutânea. Parte do benzeno inalado (30\%) é imediatamente eliminado pela expiração e o restante se distribui pelo organismo. Devido sua alta solubilidade em gordura, o benzeno absorvido se acumula nos tecidos na razão direta de seu conteúdo lipídico. A gordura funciona como um reservatório e a eliminação do benzeno é vagarosa. Cinqüenta por cento do benzeno absorvido é biotransformado predominantemente no figado, com formação de derivados mais hidrossolúveis para facilitar sua excreção através dos rins. $O$ processo de biotransformação também ocorre na medula óssea conforme descrito por Carvalho e col. (1995) citados por Pesquero (2001).

$O$ benzeno interfere no sistema produtor de células sangüíneas podendo causar efeitos como a leucopenia (redução do número de glóbulos brancos), anemia (redução drástica do número de glóbulos vermelhos), trombocitopenia (redução do número de plaquetas) e leucemia conforme citado por Pesquero (2001). A absorção de benzeno também provoca efeitos tóxicos no sistema nervoso central.

Sintomas típicos de contaminação: irritação nos olhos, pele, nariz e sistema respiratório, dores de cabeça, náuseas, anorexia, fadiga e dermatites (NIOSH, 2001).

Recomendação de limite de exposição segundo o NIOSH: concentração média ponderada pelo tempo de $0,1 \mathrm{ppm}$ ou $0,3 \mathrm{mg} / \mathrm{m}^{3}$ (NIOSH, 2001).

\subsubsection{2- Clorofórmio}

A absorção por inalação é de 60 a $80 \%$ para humanos. Após ingestão o clorofórmio é quase que totalmente absorvido tanto por animais como por humanos, também existe absorção pela pele (BLOEMEN e BURN, 1995)

O cloroförmio é distribuído pelo corpo inteiro. As concentrações mais altas são encontradas nos tecidos gordurosos, sangue, pulmões, rins e sistema nervoso. $O$ 
clorofórmio também passa pela placenta. Ele pode ser metabolizado por um citocromo até fosgênio, o qual reage com cisteína ou glutationa. Nesta biotransformação existe a formação de monóxido de carbono. Os pulmões eliminam o monóxido de carbono. Pessoas obesas possuem maior dificuldade de eliminar tanto o monóxido de carbono como o próprio excesso de clorofórmio do corpo (OGA,1996). No entanto, em grandes doses o clorofórmio pode levar a pessoa à hipotensão, depressão respiratória e miocárdica, chegando até ao óbito (MERCK,1996).

Para contaminações por clorofórmio com altas concentrações os problemas acima citados são conhecidos, porém para pequenas doses diárias ainda são necessários estudos para verificação dos efeitos ao ser humano.

Sintomas típicos de contaminação: irritação nos olhos e pele, vertigens, dores de cabeça, confusão mental, náuseas, exaustão física entre outros (NIOSH, 2001).

Recomendação de limite de exposição segundo o NIOSH: concentração média ponderada pelo tempo de $2 \mathrm{ppm}$ ou $9,78 \mathrm{mg} / \mathrm{m}^{3}$ (NIOSH, 2001).

\subsubsection{3- Tetracloreto de carbono}

O tetracloreto de carbono é rapidamente absorvido pelos pulmões, pele e tubo digestivo (OGA, 1996). Ele é um depressor do sistema nervoso central produzindo danos ao cérebro. Também produz, quando em contato com o sistema respiratório, danos às mucosas e narcose. Os casos fatais descritos na literatura são devidos à nefrotoxicidade, insuficiência cardíaca e hepatoxicidade (OGA, 1996)

Quando em exposição crônica, a pessoa começa sentindo dores nos rins culminando com desequilibrios visuais. Como também é um hepatotóxico na exposição prolongada provoca necrose, fibrose e tumores. O contato direto e prolongado com a pele provoca dermatites. Várias substâncias como etanol, isopropanol, fenobarbital e bezopireno tem mostrado potencial para efeitos sinérgicos quando combinadas com o tetracloreto de carbono (MERCK,1996 e OGA,1996). 
Sintomas típicos de contaminação: irritação nos olhos, pele, náuseas, vômitos, falta de coordenação fisica, secreção de bile, fadiga, tontura, perturbação mental e dores de cabeça e nos rins (NIOSH, 2001).

Recomendação de limite de exposição segundo o NIOSH: média ponderada pelo tempo de $2 \mathrm{ppm}$ ou $12,6 \mathrm{mg} / \mathrm{m}^{3}$ (NIOSH, 2001).

\subsubsection{4- Tolueno}

O tolueno é rapidamente absorvido quando inalado podendo comprometer os pulmões ao longo do tempo. A inalação por tempo prolongado resulta em disfunção orgânica crônica do cérebro associada com atrofia cerebelar. A maior parte do tolueno inalado é metabolizado a ácido benzóico, o qual é conjugado com glicina no figado formando o ácido hipúrico, sendo este excretado pela urina (BLOEMEN e BURN, 1995). No aparelho cardiovascular o tolueno provoca arritmias no coração (bradicardia e fibrilação ventricular), infarto do miocárdio e morte súbita. $\mathrm{O}$ tolueno não possui efeitos tóxicos crônicos sobre a medula óssea. No sistema ginecológico $\mathrm{e}$ reprodutor ele pode produzir distúrbios menstruais, aumento de prolapso uterino e da parede vaginal, malformações fetais e distúrbios do crescimento fetal (OGA, 1996).

O contato cutâneo ao tolueno, em exposição prolongada ou repetida pode causar ressecamento da pele devido à perda de óleo (da oleosidade) natural da pele (BLOEMEN e BURN,1995)

Sintomas típicos de contaminação: irritação nos olhos e nariz, dores de cabeça, euforia, parestesia, fadiga muscular, insônia, pupilas dilatadas, danos aos rins e dermatite (NIOSH, 2001).

Recomendação de limite de exposição segundo o NIOSH: concentração média ponderada pelo tempo de $100 \mathrm{ppm}$ ou $377 \mathrm{mg} / \mathrm{m}^{3}$ (NIOSH, 2001). 


\section{8- Legislação}

A legislação ambiental brasileira, por meio da resolução CONAMA $n^{\circ} 3$ de 28 de junho de 1990, fixou padrões de qualidade do ar externo, para Partículas Totais em Suspensão, Fumaça, Partículas Inaláveis, Dióxido de Enxofre, Monóxido de Carbono, Dióxido de Nitrogênio e Ozônio (BERNARDO e FAVORETO, 2001).

Nesta resolução $\mathrm{n}^{\circ}$ 3, são definidos Padrões Primários de Qualidade do Ar, como sendo as concentrações de poluentes que, se ultrapassadas, poderão afetar a saúde da população. Foram definidos também Padrões Primários de Qualidade do Ar como sendo as concentrações máximas de poluentes para proteção ao bem estar da população e mínimo efeito ao meio ambiente (BERNARDO e FAVORETO, 2001).

Estes padrões poderiam ser extrapolados para interiores, pois considera-se inclusive exposição continuada de pessoas sensíveis, como crianças e idosos, mas todo o escopo da Resolução é para poluentes da atmosfera externa. No entanto, os poluentes que estão afetando o ar externo podem passar, em parte, para o interior de ambientes, e esse passa a ser uma fonte externa.

Para cobrir a lacuna referente à poluição do ar de interiores, o Ministério da Saúde publicou a Portaria $\mathrm{n}^{\circ} 3523$, de 28 de agosto de 1998, referente à qualidade do ar de interiores climatizados.

Nesta Portaria foi definido, no seu artigo $2^{\circ}$, que seria confeccionado pelo Ministério da Saúde um Regulamento Técnico, o qual estabeleceria padrões de qualidade do ar de interiores climatizados e toda forma de controle e pré-requisitos de instalação de sistemas climatizados. No seu artigo $4^{\circ}$, item i, é definida a Síndrome dos Edifícios Doentes, a qual é dada importância nesta Portaria devido ao seu caráter persistente quando não atendidos os requisitos de manutenção previstos nesta Portaria.

Confirmando o preconizado na Portaria $\mathrm{N}^{0} 3523$, o Ministério da Saúde, por meio da Agência Nacional de Vigilância Sanitária, publicou a Resolução $\mathrm{N}^{\circ} 176$ de 24 de outubro de 2000, a qual contou, na sua confecção, com a colaboração de associações, institutos, faculdades, fundações, além do Ministério do Meio Ambiente e da Organização Pan-Americana de Saúde - OPAS. 
A Resolução $\mathrm{n}^{\circ} 176$ foi revisada e atualizada com dados adquiridos em dois anos de experiência e publicada no Diário Oficial da União em 20 de janeiro de 2003 com o título Resolução - RE $n^{\circ}$ 9, de 16 de janeiro de 2003. Esta Resolução abrange orientações técnicas sobre Padrões Referenciais de Qualidade do Ar Interior em ambientes climatizados artificialmente, de uso público e coletivo, valores máximos recomendáveis para contaminação biológica, química e parâmetros físicos do ar interior. Quanto à identificação das fontes poluentes, foram definidas quatro Normas Técnicas:

- NT 001- Método de amostragem e análise de bioaerosol em ambientes interiores.

- NT 002-Método de amostragem e análise da concentração de dióxido de carbono em ambientes interiores.

- NT 003- Método de amostragem. Determinação de temperatura, umidade e velocidade do ar em ambientes interiores.

- NT 004- Método de amostragem e análise de concentração de aerodispersóides em ambientes interiores.

Esta Resolução indica em dois quadros (I e II), recomendações para controle de possíveis fontes de poluentes em interiores. No Quadro II da Resolução, são citados os compostos orgânicos voláteis e os compostos orgânicos semi-voláteis, bem como suas possíveis fontes no ambiente interior e algumas medidas de correção para minimizar o problema. O item V desta Resolução, intitulado Fontes Poluentes, recomenda que sejam adotadas as possíveis fontes citadas nos Quadros I e II, onde encontra-se a referência sobre compostos orgânicos voláteis para fins de pesquisa e também com propósito de levantar dados sobre a realidade brasileira, assim como para avaliação e correção das situações encontradas. No entanto, as Normas Técnicas citadas não englobam amostragem ou análise de compostos orgânicos voláteis. 


\section{9- Revisão de métodos de amostragem e análise para compostos orgânicos}

As metodologias para verificação de compostos orgânicos no ar englobam geralmente a amostragem e o método de análise na mesma metodologia, porém para entender os vários métodos são descritos a seguir os métodos de amostragem separados dos métodos de análise.

\subsection{1- Métodos de amostragem de compostos orgânicos no ar}

\subsubsection{1- Carvão ativado}

Historicamente, o método de coleta para exposição ocupacional é o de bombeamento da amostra de ar através de adsorvente (carvão ativado) para concentrar os compostos orgânicos voláteis, sendo estes então posteriormente dessorvidos com dissulfeto de carbono, quando da execução da análise da amostra.

No início dos anos 1980 foram desenvolvidos monitores passivos com carvão ativado para amostragem ocupacional. O princípio de operação destes monitores é a difusão, e são recomendados para avaliação por 8 horas seguidas correspondente ao dia de trabalho, para poder comparar com os padrões de exposição ocupacional. Entretanto, os processos de manufatura destes monitores deixavam resíduos de compostos orgânicos voláteis no carvão ativado, ocasionando incerteza nas medições devido ao fato de que as concentrações ambientais estarem no nível de partes por bilhão. Porém, o alto nível de contaminação de fundo do material adsorvente pode ser compensado pelo maior tempo de amostragem, uma semana ou mais, e assim esta técnica pode ser adotada em muitos estudos sobre poluição do ar em ambientes internos (BLOEMEN e BURN, 1995). 


\subsubsection{2- Tenax}

Os problemas de resíduos de fundo com o carvão ativado, bem como problemas em obter adsorventes químicos recuperáveis, indicou o caminho para pesquisas para obtenção de outros adsorventes.

Um polímero denominado comercialmente Tenax (polímero do óxido de 2,6difenil fenileno) foi largamente adotado durante os anos 70 como um adsorvente mais seguro para o nível de ppb do que o carvão ativado (USEPA, 1984). Tenax, devidamente limpo, possui um resíduo de fundo de compostos orgânicos voláteis muito baixo. Ele também é estável acima de $250^{\circ} \mathrm{C}$, o que o classifica como propício para técnica de dessorção térmica, porém não tão indicado para dessorção por solvente. A desvantagem do Tenax é a produção artificial de fenol, pois este participa da cadeia polimérica bem como o benzaldeído, por exemplo, o Tenax demonstrou uma ineficiência muito grande na adsorção de muitos orgânicos voláteis como o cloreto de vinila.(BLOEMEN e BURN, 1995)

\subsubsection{3- Sistemas multiadsorventes}

No final dos anos 1980, foi desenvolvido um sistema combinando Tenax e carvão Ativado. Foram desenvolvidos novos tipos de carvão ativado como Spherocarb, Carbosieve, estes com a função de obter menor resíduo de fundo.

Utilizando um sistema com adsorventes em série, aplicando em geral o Tenax como primeiro adsorvente e carvão ativado como segundo, o Tenax coleta a parte de maior ponto de ebulição dos compostos orgânicos voláteis e o carvão ativado coleta os de menor ponto de ebulição que passam pelo Tenax. Os sistemas também podem utilizar três adsorventes: Tenax, Ambersorb e Spherocarb ou Carbosieve. Todos esses sistemas permitem a coleta de uma grande variedade de compostos orgânicos voláteis.( BLOEMEN e BURN,1995) 


\subsubsection{4- Amostragem direta}

Este método foi desenvolvido nos anos 1970 para amostragem em ambientes abertos evitando a passagem pela adsorção e dessorção, a qual gera contaminação (entretanto, isto requer uma grande sensibilidade por parte do sistema de detecção). O método pode envolver amostragem em tempo real em laboratórios móveis, com injeção direta da coleta da amostra de ar para um trap frio ligado a um cromatógrafo a gás; ou amostrando em um canister de alumínio polido ou aço para posterior análise em laboratório.( BLOEMEN e BURN,1995)

\subsubsection{5- Comparação de métodos de amostragens}

Os métodos de amostragem não são simples e nem mesmo únicos para se transformarem em padrões mundiais, tanto para amostragem atmosférica como para interiores. Nos Estados Unidos segundo Bloemen e Burn (1995), os dois métodos preferidos são os que utilizam Tenax ou Canister. Estes dois métodos foram comparados sob condições controladas em uma casa desocupada. Foram injetados na casa: 3,9 e $27 \mu \mathrm{g} / \mathrm{m}^{3}$ de compostos orgânicos voláteis. Os resultados mostraram que os dois métodos estão em concordância. Porém, em recente estudo realizado com amostragens, tanto com tubos adsorvedores e canisters em São Paulo, indicaram que para compostos como aromáticos por exemplo, a amostragem com tubos mostrou variação menor. Também foi citada a dificuldade de trabalhar com canisters devido ao elevado peso e tamanho, alto custo e necessidade de mão de obra especializada para seu correto manuseio (COLÓN e col.,2001).

Na Europa segundo Bloemen e Burn (1995), os dois métodos mais comuns são os que utilizam tubos com Tenax ou Carvão Ativado. Um estudo empregando ambos os métodos encontrou alta consistência nos níveis de compostos orgânicos voláteis totais no carvão ativado. A diferença pode ser devida à presença de alguns compostos orgânicos muito voláteis como pentano e isopentano, os quais são adsorvidos pelo carvão ativado, porém com pouca retenção pelo Tenax (BLOEMEN e BURN,1995). 


\subsection{2- Métodos de análise de compostos orgânicos voláteis}

As amostras são geralmente analisadas por separação em cromatografia gasosa. Três formas de deteç̧ão são comumente usadas: deteç̧ão por ionização de chama, captura de elétrons e espectrometria de massas. Apenas a cromatografia gasosa com detecção por espectrometria de massas tem a capacidade de identificar os componentes sem a necessidade de injeção de padrões analíticos. Os detetores cromatográficos por ionização de chama ou captura de elétrons não são capazes de detectar substâncias químicas que eluem no mesmo tempo de retenção. Também, a resposta do detector por ionização de chama é insatisfatória para clorados e outros halogenados, tanto que não são indicados para estes tipos de amostras. (COLLINS,BRAGA e BONATO,1990)

O espectrômetro de massas, através de fragmentação de substâncias separadas anteriormente pela coluna cromatográfica, identifica as substâncias comparando sua sequiência de fragmentos com uma biblioteca interna. Os métodos indicados pela USEPA para análise de compostos orgânicos voláteis são o Compendium Method TO-14A-Determination of Volatile Organic Compounds (VOC) in Ambient Air Using Specially Prepared Canisters With Subsequent Analysis By Gas Chromatography (USEPA,1999); Compendium Method TO-15 - Determination Of Volatile Organic Compounds (VOC) in Air Collected in Specially- Prepared Canisters and Analyzed by Gas Chromatography Mass-Spectrometry (GC/MS) (USEPA,1999); Method TO-1 - Method for the determination of Volatile Organic Compounds in Ambient Air Using Tenax Adsorption and Gas Chromatography/Mass Spectrometry (GC/MS) (USEPA,1984) e Method -TO 2 - Method for the Determination of Volatile Organic Compounds in Ambient Air by Carbon Molecular Sieve Adsorption and Gas Chromatography/Mass Spectrometry (GC/MS) (USEPA,1984). Sendo que os métodos TO-1 e TO-2 datam de 1984. Estes foram aperfeiçoados pelos métodos TO-14 A e TO-15 que datam de janeiro de1999. Os métodos da USEPA citados compreendem amostragem e análise, porém estes tratam a amostra da mesma forma, ou seja, passa-se um volume de ar por tubo empacotado com adsorvente (TO-1 e TO-2) ou coletam a amostra através de um canister de aço inoxidável (TO-14A e TO-15) e passam a amostra para um tubo com multi- 
adsorventes para concentração dos compostos orgânicos voláteis, posteriormente liberando-os através de uma dessorção térmica indo para um trap a baixa temperatura e posterior aquecimento para liberação das substâncias para análise em sistema de cromatografia gasosa/espectrometria de massas (CG/EM) ou apenas por cromatografia gasosa (CG) com detetores específicos como ionização de chama, captura de elétrons ou um conjunto com os dois detetores. Estes métodos proporcionam a vantagem de coletar a amostra e analisá-la sem o efeito de diluição, ou seja, pode coletar um volume pequeno de amostra que mesmo assim será representativo. Os métodos TO-1 e TO-2, respectivamente indicam a coleta de amostra por tubos com adsorventes Tenax e Carbon Molecular Sieve (peneira molecular de carbono), mas estes não possuem uma metodologia de amostragem automática como indicado nos métodos TO- 14 A e TO- 15.

Nos métodos TO- 14 a e TO-15, é englobada a evolução dos sistemas de coleta de amostras utilizando canisters para amostragem onde a eficiência para retenção de compostos orgânicos voláteis é significativa em relação aos métodos TO1 e TO-2 porém, não invalidando-os tanto que a USEPA os mantém para consulta e utilização em forma de opção caso o interessado não disponha dos outros recursos indicados nos métodos TO-14 A e TO-15. No método TO-2 é citado que o mesmo pode ser usado por laboratórios "simples", ou seja, que não possuam recursos como a dessorção térmica. Porém, Pellizzari (1984) monstrou que o sistema de amostragem com tubos de Tenax, com posterior dessorção térmica e criogenia (métodos USEPA) faz com que as substâncias tenham possibilidade de reação entre si devido ao fato de estarem concentradas a baixas temperaturas e submetidas posteriormente a aquecimento, provocando resultados distorcidos.

Brancaleoni (1999) cita o problema de coletar as amostras com adsorventes hidrofóbicos, que são maioria dentre os conhecidos, os quais retém uma determinada quantidade de água e devido a isso, os volumes amostrados são os menores possíveis comprometendo o volume de amostra devido ao efeito criogênico nos sistemas indicados pelos métodos da USEPA. A solução proposta por Brancaleoni é o Graphitized Carbon Black (carbono grafitizado), o qual possui uma performance melhor que os indicados no método TO-17 da USEPA. 
Como um sistema alternativo à dessorção térmica, Schuh e col. (1997), indicaram e utilizaram a dessorção com solvente capaz de extrair todas as substâncias adsorvidas de interesse, porém, como condição analítica, a quantidade de ar amostrada deve ser maior do que em relação à dessorção térmica. Lamb e col. (1980) e Kahl e col. (1999) também citam e utilizam em seus estudos, esta técnica como alternativa para análise de compostos orgânicos voláteis. 


\section{2- OBJETIVOS}

\section{1- Objetivo geral}

Estudar a presença de compostos orgânicos voláteis tóxicos, em ambientes interiores climatizados com fins ocupacionais, isentos de tabagismo, e contribuir para a elaboração de normas que visem o controle de compostos orgânicos voláteis tóxicos nesses ambientes.

\section{2- Objetivos específicos}

Avaliar a presença e a concentração de benzeno, clorofórmio, tetracloreto de carbono e tolueno no ar de escritórios climatizados, com ausência de tabagismo, no centro da Cidade de São Paulo;

Determinar os compostos orgânicos voláteis presentes no ar dos ambientes pesquisados, classificando-os por abundância (freqüência);

Correlacionar os compostos orgânicos voláteis encontrados nos ambientes estudados com suas possíveis fontes internas;

Analisar os compostos orgânicos voláteis presentes no ar externo para verificar correlação com os compostos orgânicos voláteis encontrados no ar dos ambientes internos estudados;

Adaptar metodologia de amostragem e análise, baseando-se nos métodos indicados pelo NIOSH para compostos orgânicos voláteis;

Comparar os resultados obtidos nos ambientes estudados com as concentrações citadas na literatura internacional;

Comparar os resultados obtidos em relação aos diferentes tipos de sistemas de condicionamento de ar presentes nos ambientes estudados;

Mostrar a necessidade de monitorar os compostos orgânicos voláteis, carcinogênicos ou não, em ambientes interiores climatizados, com intuito de controlar as fontes de emissões de poluentes para evitar/amenizar os sintomas relacionados com a Síndrome do Edifício Doente e da Doença Relacionada com o Edifício. 
2.3- Hipótese

Existem compostos orgânicos voláteis nocivos a saúde humana no ar de interiores climatizados de fins ocupacionais, isentos da prática de tabagismo. 


\section{3- MATERIAIS E MÉTODOS}

\section{1- Região do Estudo}

A região escolhida para o desenvolvimento do estudo foi a cidade de São Paulo, especificamente o centro da cidade nas áreas compreendidas pelas ruas: Consolação, Maria Antonia, Piauí, Itambé, Maria Borba e Amaral Gurgel, além do Elevado Costa e Silva e o campus de uma universidade localizada dentro do perímetro das ruas Consolação, Maria Antonia, Piauí e Itambé.

Estas áreas foram escolhidas devido ao intenso movimento de veículos, existência de postos de gasolina nas proximidades, principalmente na Rua da Consolação, a existência de escritórios de variados tipos, com diferentes conformações de materiais internos e também com diferentes tipos de condicionadores de ar.

No tocante aos condicionadores de ar trabalhou-se com interiores climatizados com:

- Ar condicionado tipo janela, ou seja, aparelho instalado na janela ou na parede do escritório;

- Sistema de ar condicionado tipo SPLIT;

- Central de ar condicionado de grande porte, ou seja, sistema que atua condicionando $o$ ar de todo o andar de um edificio.

O ponto em comum com todos os escritórios foi a ausência da prática do tabagismo no interior dos mesmos.

A época do ano escolhida para coleta de amostras foi o verão, pois se caracteriza pelas altas temperaturas médias diárias e por conseqüência o uso efetivo de condicionadores de ar.

Todas as amostras de escritórios tiveram como comparativo direto as amostras do ar externo ao seu sistema de condicionamento de ar. 


\section{2- Método de Análise}

A metodologia analítica utilizada foi baseada nos métodos NIOSH 1003 (1994a), NIOSH 1500 (1994b) e NIOSH 1501 (1994c), respectivamente relacionados com halogenados, hidrocarbonetos e aromáticos. Também por similaridade com os métodos NIOSH seguiu-se os métodos OSHA 05 para clorofórmio, OSHA 07 para vapores orgânicos, OSHA 12 para benzeno e OSHA 111 para tolueno.

Estes métodos possuem pontos em comum como a coleta das amostras através de tubos de vidro com preenchimento de carvão ativado succionados por bombas de baixa vazão, dessorção das substâncias coletadas por dissulfeto de carbono e análise via cromatografia gasosa. A técnica cromatográfica destes métodos cita que a análise deva ser realizada em coluna empacotada e detector por ionização de chama. Porém, para detecção de substâncias na ordem de $\mu \mathrm{g} / \mathrm{L}$ faz-se necessário o uso de detetores cromatográficos com sensibilidade para tal concentração. Os detetores de captura de elétrons (específicos para halogenados) e detectores por ionização de chama, sendo que este último citado em todos os métodos anteriores como sistema de detecção na ordem $\mathrm{mg} / \mathrm{Kg}$ possuem sensibilidade para deteç̧ão a nível $\mu \mathrm{g} / \mathrm{L}$, porém não são todas as substâncias contempladas por estes com repetibilidade de resultados. Um dos detectores com sensibilidade para captar concentrações na ordem de $\mu \mathrm{g} / \mathrm{L}$ é o Espectrômetro de Massas.

Portanto para se realizar as análises cromatográficas alterou-se o sistema de detecção de Ionização de Chama para Massas e, por conseguinte a coluna cromatográfica utilizada foi do tipo capilar, pois os Espectrômetros de Massas trabalham apenas com este tipo de coluna, a qual possui uma resolução melhor de picos cromatográficos quando comparado com a resolução de uma coluna empacotada.

A sequiência analítica citada pelos métodos NIOSH foi seguida desde a coleta, preparação da amostra, análise e calibração com padrões. Realizamos as análises da seguinte forma:

Coleta da amostra conforme o item 3.3.

- Retirada do tubo com a amostra do gelo seco para que gradualmente voltasse à temperatura ambiente. 
Dessorção das substâncias contidas no carvão ativado do tubo passando este carvão para um frasco limpo de $3 \mathrm{~mL}$ com tampa e em seguida adicionando com uma seringa de vidro de $1000 \mu \mathrm{L}$ o volume de 1 mililitro de dissulfeto de carbono, tampando e agitando esporadicamente o frasco por trinta minutos.

- Injeções de $2 \mu \mathrm{L}$ da amostra dessorvida pelo dissulfeto de carbono no cromatógrafo através do sistema de injeção automática tanto para análise quantitativa como para qualitativa.

* Obedecendo o mesmo processo de dessorção, o mesmo foi realizado para tubo com carvão ativado sem amostra como prova em branco.

* Mediante o resultado fornecido pelas áreas dos picos das amostras injetadas foram injetados padrões para elaboração de curva analítica para quantificação de benzeno, clorofórmio, tetracloreto de carbono e tolueno.

As análises quantitativas foram realizadas no modo de monitoramento de íons selecionados (SIM) do Espectrômetro de Massas e as análises qualitativas pelo modo de varredura de íons (SCAN). Por este modo a identificação das substâncias foi realizada através de comparação com a biblioteca interna NIST/USEPA/NIH do equipamento com mais de 128.000 espectros de massas.

$\mathrm{Na}$ análise quantitativa pelo modo SIM especificou-se os cinco principais fragmentos das moléculas a serem quantificadas e estes foram monitorados. Para determinar quais seriam estes fragmentos injetou-se no cromatógrafo as substâncias isoladamente e verificou-se a abundância relativa dos fragmentos. Este processo de cinco fragmentos foi necessário devido a similaridade entre tetracloreto de carbono e clorofórmio e também benzeno e tolueno.

Para quantificação de tetracloreto de carbono, clorofórmio, benzeno e tolueno seguiu-se esta forma de cálculo:

$$
\mathrm{As}-\mathrm{Ab}=\mathrm{A}
$$

Procurar com A, a equivalência na curva de calibração da substância, obtendo o valor para $\mathrm{M} \mathrm{em} \mu \mathrm{g}$. 
$\mathrm{M} / \mathrm{V}=\mathrm{C}$ em $\mu \mathrm{g} / \mathrm{L}$

Relação:

$\begin{array}{ll}1 \mathrm{ppm} \mathrm{v} & \rightarrow \mathrm{x} \mathrm{mg} / \mathrm{m}^{3} \text { ou } \mu \mathrm{g} / \mathrm{L} \\ \mathrm{Cp} & \rightarrow \mathrm{C} \mu \mathrm{g} / \mathrm{L}\end{array}$

$\mathrm{Cp} \times 1000=\mathrm{Cb} \mathrm{ppb} v$

Área da substância na amostra (As) - área da substância no branco (Ab) \{ambas corrigidas pelo seu coeficiente de dessorção $\}=(A)$ área efetiva da substância na amostra

Utilizou-se a curva de calibração da substância para com o valor de A chegar a quantidade em massa da substância na amostra (M) sendo a unidade em micrograma.

Dividiu-se a massa $M$ pelo volume (V) de ar amostrado. Encontrou-se assim a concentração (C) da substância na amostra na unidade de $\mu \mathrm{g} / \mathrm{L}$.

Segundo NIOSH (2001), as relações de transformação da unidade de ppm v para $\mathrm{mg} / \mathrm{m}^{3}$ são:

$1 \mathrm{ppm} v$ de benzeno $=3,19 \mathrm{mg} / \mathrm{m}^{3}$

$1 \mathrm{ppm} v$ de tolueno $=3,77 \mathrm{mg} / \mathrm{m}^{3}$

$1 \mathrm{ppmvde} \mathrm{CCl}_{4} \quad=6,29 \mathrm{mg} / \mathrm{m}^{3}$

$1 \mathrm{ppm} v$ de $\mathrm{HCCl}_{3}=4,88 \mathrm{mg} / \mathrm{m}^{3}$

Considerando que se a unidade $\mathrm{mg} / \mathrm{m}^{3}$ for dividida por 1000 equivale a $\mu \mathrm{g} / \mathrm{L}$, pode-se relacionar o resultado de $\mathrm{C}$ para uma determinada substância diretamente com a relação anteriormente citada obtendo o resultado $(\mathrm{Cp})$ em ppm v. Sendo que para obter o resultado em ppb v (Cb) basta multiplicar o Cp por 1000 .

Segundo a IUPAC as unidades ppm e ppb estão em desuso em química, porém nesta tese - foco Saúde Pública/Poluição do Ar - utilizamos tais unidades pois as referências bibliográficas fizeram uso destas para reportarem os resultados de compostos orgânicos no ar de interiores. Estabeleceu-se assim uma comparação direta de unidades. 


\subsection{1- Instrumentação analítica}

O equipamento utilizado para as análises foi um Espectrômetro de Massas modelo GCMS-QP5050A, marca Shimadzu, pertencente à Fundação Jorge Duprat Figueiredo de Segurança e Medicina do Trabalho (FUNDACENTRO/MTb) com a configuração:

Analisador de ions; quadrupólo com pré-quadrupólo; fonte de ionização - Impacto de elétrons de $70 \mathrm{eV}(1600 \mathrm{Kcal} / \mathrm{mol})$; varredura de íons (full scan) ou monitoramento de íons selecionados (SIM). O cromatógrafo a gás que pertence ao sistema é um modelo GC-17AA, marca Shimadzu. A coluna cromatográfica utilizada é indicada para compostos orgânicos voláteis, com fase estacionária composta de $7 \%$ de metilcianopropil e 7\% de fenil silicone (média polaridade), marca Quadrex, com 30 metros de comprimento, 0,32 milímetros de diâmetro, $0,25 \mu \mathrm{m}$ de espessura de filme e temperatura máxima de trabalho $290^{\circ} \mathrm{C}$. As condições de análise cromatográfica foram:

Temperatura do injetor: $200^{\circ} \mathrm{C}$

Volume de injeção: $2 \mu \mathrm{L}$

Razão de divisão da amostra: 1:5

Vazão da coluna: $1,4 \mathrm{~mL} / \mathrm{min}$

Programação do forno: $35^{\circ} \mathrm{C}$ por 5 minutos, rampa de $5^{\circ} \mathrm{C} / \mathrm{min}$ até $80^{\circ} \mathrm{C}$ mantendo esta temperatura até 19 minutos de análise.

Temperatura do Espectrômetro de Massas: $250^{\circ} \mathrm{C}$.

\subsection{2-Reagentes e padrões}

Foram utilizados como padrões cromatográficos: benzeno, clorofórmio, tetracloreto de carbono e tolueno; todos com grau de pureza cromatográfica. Para dessorção das substâncias adsorvidas pelo carvão ativado nos tubos de amostragem, utilizou-se dissulfeto de carbono com grau de pureza cromatográfica conforme citado nos métodos NIOSH 1003 (1994a), NIOSH 1500 (1994b) e NIOSH 1501 (1994c).

A seguir a rastreabilidade das substâncias utilizadas: 
- Tetracloreto de carbono - marca Aldrich, lote CI00739CI

- Clorofórmio - marca Merck, lote 1156174

- Benzeno - marca Fluka, lote 11217/1

- Tolueno - marca Fluka, lote 12002/1

- Dissulfeto de carbono - marca Alfa Aesar, lote D15H14.

Os padrões preparados para quantificação das substâncias de interesse das amostras foram preparados em dissulfeto de carbono. Todos os padrões externos utilizados foram preparados no dia da análise se baseando também nos resultados obtidos nas amostras. As concentrações dos padrões de trabalho foram de $\mu \mathrm{g} / \mathrm{L}$, pois segundo a literatura técnica consultada, como por exemplo Cheng (2000) (1999), Perry (1997) e Srivastava e col. (2000), as concentrações de compostos orgânicos voláteis em interiores estão em torno de ppb volume.

\subsubsection{1- Solução estoque}

A solução estoque (SL) foi preparada com auxílio de uma balança analitica com precisão de $0,01 \mathrm{mg}$ e micro-seringas de vidro, sendo que sua composição ficou:

* $880 \mu \mathrm{g} / \mathrm{mL}$ de benzeno em dissulfeto de carbono

* $870 \mu \mathrm{g} / \mathrm{mL}$ de tolueno em dissulfeto de carbono

* $1590 \mu \mathrm{g} / \mathrm{mL}$ de tetracloreto de carbono em dissulfeto de carbono

- $1500 \mu \mathrm{g} / \mathrm{mL}$ de clorofórmio em dissulfeto de carbono

\subsubsection{2- Padrões analíticos}

Foram preparados padrões com as seguintes concentrações iniciais para contemplar os testes de validação e também as análises das amostras:

Padrão $1 \quad 20 \mu \mathrm{L}$ de SL em $2 \mathrm{~mL}$ de $\mathrm{CS}_{2}$

Padrão $2 \quad 10 \mu \mathrm{L}$ de SL em $2 \mathrm{~mL}$ de $\mathrm{CS}_{2}$

Padrão $35 \mu \mathrm{L}$ de SL em $2 \mathrm{~mL}$ de $\mathrm{CS}_{2}$

Padrão $4 \quad 5 \mu \mathrm{L}$ de SL em $4 \mathrm{~mL}$ de $\mathrm{CS}_{2}$

Padrão $5 \quad 2,5 \mu \mathrm{L}$ de SL em $4 \mathrm{~mL}$ de $\mathrm{CS}_{2}$

Padrão $6 \quad 2,5 \mu \mathrm{L}$ de SL em $8 \mathrm{~mL}$ de $\mathrm{CS}_{2}$ 
Demonstra-se na Tabela 6 as massas das substâncias por padrão.

Tabela 6- Tipo de padrão por massa de substância contida por $\mathrm{mL}$

\begin{tabular}{lcccc}
\hline Padrão & $\mu \mathrm{g} / \mathrm{mL}$ benzeno & $\mu \mathrm{g} / \mathrm{mL}$ tolueno & $\mu \mathrm{g} / \mathrm{mL} \mathrm{CCl}_{4}$ & $\mu \mathrm{g} / \mathrm{mL} \mathrm{HCCl}_{3}$ \\
\hline 1 & 8,8 & 8,7 & 15,9 & 15,0 \\
2 & 4,4 & 4,35 & 7,95 & 7,5 \\
3 & 2,2 & 2,18 & 3,98 & 3,75 \\
4 & 0,22 & 0,22 & 0,40 & 0,38 \\
5 & 0,11 & 0,11 & 0,20 & 0,19 \\
6 & 0,05 & 0,05 & 0,10 & 0,09 \\
\hline
\end{tabular}

\subsection{3- Validação baseada no critério NIOSH para o método analítico}

A metodologia analítica como citada anteriormente foi baseada nos métodos NIOSH, porém mesmo utilizando a cromatografia gasosa como base analítica, não utilizou-se o mesmo detector citado nestes métodos, o qual é o detector por ionização de chama. Utilizou-se para tal o Espectrômetro de Massas que possui sensibilidade para detectar a concentração esperada nas amostras e também ao mesmo tempo qualificar, ou seja, identificar a substância detectada comparando com uma biblioteca interna (NIST/EPA/NIH) do equipamento.

\subsubsection{1 - vetermınação do Limite de Detecção do Método Analítico}

O Limite de Deteç̧ão, em geral é definido como a quantidade ou concentração de um analito que fornece uma resposta significativamente diferente do branco, ou seja, três vezes o desvio padrão do branco. A medida direta do limite de deteç̧ão do branco é algo inconveniente em cromatografia devido geralmente a resposta do branco ser baixa. Estimativas destes parâmetros podem ser feitas com dados obtidos de uma série de análises de padrões onde as respostas são nas vizinhanças da resposta do branco. A regressão da curva é obtida através dos dados da concentração do analito "versus" área do pico resultando em uma reta linear. Assumindo que o Desvio Padrão do Branco e a precisão dos dados na reta são 
lineares, o erro padrão da estimativa para curva de regressão pode ser substituído pelo Desvio Padrão do Branco na equação citada. O erro padrão da estimativa de uma reta é o equivalente matemático do desvio padrão para dados tabulados (NIOSH,1998).

Portanto para verificar esta metodologia analítica com este sistema de detecção foram utilizados os padrões citados na Tabela $6 \mathrm{com}$ intuito de identificar o Limite de Detecção do Método Analítico.

Foram construídas retas onde os gráficos representaram áreas "versus" massas das substâncias contidas nos padrões. Mediante os resultados foram calculados os coeficientes $\left(\mathrm{r}^{2}\right)$ para verificar a linearidade do detetor e a equação obtida para cálculo do Limite de Detecção.

\subsubsection{2- Determinação da Precisão e Recuperação do Método Analítico}

Também foram realizados testes para verificação da Precisão e Recuperação do Método Analítico onde foram preparadas soluções com três massas diferentes de tetracloreto de carbono, clorofórmio, benzeno e tolueno, próximas às concentrações esperadas nas amostras.

Para os cálculos estatísticos de confirmação foi utilizado como referência o NIOSH (1998). A validação da metodologia foi feita através dos cálculos: das Médias das análises, dos Desvios Padrão, Coeficientes de Variação ou Desvios Padrão Médios e Coeficiente de Variação Total da Metodologia.

Para aprovação no critério NIOSH o método analítico para um nível de confiança de $95 \%$ para qualquer amostra individual deve possuir um coeficiente de variação de 0,126 e um coeficiente de variação total dos dados de laboratório não superior a 0,105 tomando por base 18 amostras (15 graus de liberdade) sendo 6 para cada nível de concentração (NIOSH, 1998). 


\section{3- Método de coleta de amostra}

Os métodos de coleta de amostra seguidos foram do NIOSH, porém encontrou-se a mesma metodologia indicada na OSHA e ASTM. Os métodos NIOSH seguidos foram 1003 (1994a), 1500 (1994b) e 1501 (1994c) como citado no item 3.2. Estes métodos consistem em amostrar através de tubos de vidro com empacotamento interno de carvão ativado derivado de coco, sendo que a sucção do ar amostrado é proveniente de uma bomba de baixa vazão. Segundo também o Supelco Air Methods Guide (1999), o carvão ativado é o melhor adsorvente para benzeno, tolueno, clorofórmio e tetracloreto de carbono, substâncias as quais foram quantificados.

\subsection{1- Materiais utilizados nas coletas}

Os tubos utilizados foram da marca SKC, Catalog Number 226-01, lote 120, com $70 \mathrm{~mm}$ de comprimento e $4 \mathrm{~mm}$ de diâmetro, com $100 \mathrm{mg}$ de carvão ativado (20/40 mesh) na camada analítica e $50 \mathrm{mg}$ de carvão ativado na camada controle. As bombas utilizadas eram de dois modelos:

- Modelo ALPHA-1 da marca Dupont e

Modelo VSS-5 da marca Buck Genie.

Estes tipos de bombas são dotados de baterias recarregáveis que possuem uma autonomia de funcionamento para até dez horas de trabalho contínuo.

O método TO-2 da USEPA indica de 0,02 a $0,5 \mathrm{~L} / \mathrm{min}$ e o Supelco Air Methods Guide indica de 0,01 a 0,2 L/min, sendo que os métodos NIOSH indicam a vazão de $0,2 \mathrm{~L} / \mathrm{min}$. Portanto, tomando por base as três referências adotamos 0,2 $\mathrm{L} / \mathrm{min}$. A calibração das bombas para amostragem foram realizadas através de um calibrador de vazão - Primary Calibrator, marca Gilian Instrument Corporation , USA, modelo Gilibrator 2 - este calibrador possui fotocélulas que indicam a passagem de bolhas de sabão por um tubo de vidro com volume calibrado. A escolha desta vazão deve-se ao motivo que a vazão de amostragem não pode ser alta pelo motivo do risco de arraste por força mecânica das substâncias que foram adsorvidas 
pela substância estacionária (carvão ativado) no tubo. Sendo forças de Van der Walls as preponderantes no fenômeno de adsorção, duas situações ou possibilidades poderiam arrastar os componentes adsorvidos; uma seria a força mecânica citada proporcionada pela própria vazão do ar, ou seja, apenas pela passagem do ar pelo tubo que é estreito, as moléculas são forçadas a se comprimir umas nas outras sendo arrastas assim para fora dos interstícios dos adsorventes.

A segunda situação seria o fator relacionado com a energia térmica, onde a temperatura em elevação proporcionaria ao sistema um excesso de energia que ocasionaria a vibração das moléculas dentro dos interstícios das substâncias adsorvedoras permitindo assim que as substâncias adsorvidas se desligassem, quebrando as fracas forças de Van der Walls que as unia aos seus adsorventes e saindo pela outra ponta do tubo (COLLINS,BRAGA e BONATO,1990).

Tanto as bombas como os tubos SKC utilizados para coleta das amostras foram cedidos pela Fundação Jorge Duprat Figueiredo de Segurança e Medicina do Trabalho (FUNDACENTRO/MTb).

As bombas com os tubos acoplados para coleta de amostras foram colocados em cima das mesas de trabalho na direção dos trabalhadores sentados a estas mesas. Ao final da coleta, as pontas dos tubos foram seladas com tampas de Teflon, transportadas em recipientes com gelo seco e armazenadas na temperatura de $-20^{\circ} \mathrm{C}$ por 24 horas, sendo posteriormente analisadas.

Todas as referências para o tempo de coleta de amostra indicam como parâmetro a concentração de ppm vol. das substâncias no ar, ou seja, foram necessários testes como descritos no item 3.2.2 para se estabelecer o tempo adequado levando em consideração o ambiente amostrado, expectativa de concentração (ppb volume como referenciado anteriormente por CHENG (2000),1999 e PERRY,1997), autonomia de funcionamento da bomba amostradora e também características inerentes às funções orgânicas amostradas em relação à adsorção pelo carvão ativado derivado de coco. 


\subsection{2- Validação do método de coleta}

A metodologia utilizada para validar o sistema de coleta foi baseada no tempo de amostragem. Buscamos com essa técnica verificar se a coleta de amostra era efetiva e o tempo de coleta, sendo que o parâmetro seria o resultado das análises cromatográficas onde ficaria indicado em que tempo o tubo com carvão ativado ficaria saturado. Esta alternativa foi empregada devido à dificuldade de gerar uma atmosfera padrão com concentrações no nível de ppb volume mesmo por bombas difusoras para as substâncias: tetracloreto de carbono, clorofórmio, benzeno e tolueno.

Segundo Goyanes, citado por Cardoso (1995) a Tabela 7 demonstra que a menor concentração com nível confiável de repetibilidade de resultados é 0,1 ppm volume, ou seja, de dez a cem vezes maior que o nível esperado para benzeno, clorofórmio e tetracloreto de carbono em ambientes interiores. 
Tabela 7 - Resumo dos tipos mais comuns para geração de atmosferas controladas e suas especificações.

\begin{tabular}{|c|c|c|c|c|c|c|}
\hline Método & \begin{tabular}{|c|} 
Faixa de \\
concentração
\end{tabular} & $\begin{array}{c}\text { Pressão } \\
\text { de } \\
\text { operação } \\
\text { (atm) }\end{array}$ & $\begin{array}{c}\text { Perdas } \\
\text { por } \\
\text { adsorção }\end{array}$ & $\begin{array}{l}\text { Custos de } \\
\text { instalação }\end{array}$ & $\begin{array}{c}\text { Tempo de } \\
\text { estabilização }\end{array}$ & $\begin{array}{c}\text { Complexidade } \\
\text { do } \\
\text { equipamento }\end{array}$ \\
\hline $\begin{array}{l}\text { Sistema } \\
\text { estático }\end{array}$ & $\mathrm{ppm}-50 \%$ & $\begin{array}{ll}0,001 & a \\
150 & \end{array}$ & $\begin{array}{l}\text { Média- } \\
\text { alta }\end{array}$ & Baixo & $\begin{array}{l}\text { Vários } \\
\text { minutos }\end{array}$ & baixa \\
\hline $\begin{array}{l}\text { Sistemas } \\
\text { dinâmicos }\end{array}$ & & & & & & \\
\hline Injeção & $1 \mathrm{ppm}-0,1 \%$ & $\geq 1$ & Baixa & Médio-alto & $\cong 1$ minuto & Média-alta \\
\hline Difusão & $0,1-500 \mathrm{ppm}$ & $\approx 1$ & Baixa & Médio & vários min. & Baixa-média \\
\hline Permeação & $50-200 \mathrm{ppm}$ & $\approx 1$ & Baixa & Baixo-médio & Vários min. & Baixa-média \\
\hline $\begin{array}{l}\text { Pressão de } \\
\text { vapor }\end{array}$ & $50 \mathrm{ppm}-10 \%$ & $\approx 1$ & Baixa & Médio & $\cong 5$ minutos & Baixa \\
\hline Eletrólise & ppm-1\% & $\approx 1$ & Baixa & Médio & vários min. & Média \\
\hline $\begin{array}{l}\text { Reação } \\
\text { química }\end{array}$ & ppm $-1 \%$ & $\approx 1$ & $\begin{array}{l}\text { Baixa- } \\
\text { média }\end{array}$ & Médio & Vários min. & Média \\
\hline
\end{tabular}

Fonte: Cardoso (1995)

Portanto, a alternativa para validar o sistema foi utilizar um ambiente interior (escritório) com grande possibilidade de contaminação por benzeno, tolueno, clorofórmio e tetracloreto de carbono. Para tal escolheu-se um escritório localizado dentro da FUNDACENTRO ao lado de um laboratório de química orgânica onde são manuseadas estas substâncias. A intenção foi garantir um ambiente que contivesse estas substâncias e não se distanciasse da realidade de outros ambientes interiores no tocante a conformação física e materiais de uso de um escritório.

Os testes foram realizados em um mesmo dia sendo que foram retiradas amostras do ar nos intervalos de 10 horas, sendo de hora em hora neste escritório com o ar condicionado (médio porte) ligado e mantido na faixa de 21 a $23^{\circ} \mathrm{C} \mathrm{e}$ umidade relativa na faixa de 45 a $60 \%$. Os tubos utilizados foram do tipo 226-01 da SKC, com enchimento de carvão ativado derivado de côco com massa de $100 \mathrm{mg}$ na camada analítica e $50 \mathrm{mg}$ na camada controle. Estes tempos de coleta estão indicados também na referência OSHA (1999) e NIOSH (1998) com relação ao levantamento 
do tempo de coleta. As análises cromatográficas verificaram se as substâncias de interesse foram coletadas e o tempo onde havia o máximo de captação de amostra antes da saturação do carvão ativado.

\subsection{3- Avaliação do adsorvente e dessorvedor}

Para avaliação da capacidade de adsorção do carvão ativado e também do dessorvedor utilizado para extração das substâncias de interesse na amostragem, a técnica utilizada foi a de estudo de recuperação recomendada pelo NIOSH (1998) e OSHA (1999). Esta técnica é baseada na adição de soluções padrão no adsorvente a ser empregado. $\mathrm{O}$ adsorvente utilizado foi o carvão ativado derivado de côco e o dessorvedor foi o dissulfeto de carbono grau cromatográfico.

Seguiu-se o seguinte procedimento: Foram adicionados os seguintes volumes da solução estoque (SL) - 0,2;0,5;1,0;1,5 e $2,0 \mu \mathrm{L}$ a 30 frascos de $2 \mathrm{~mL}$ com a camada analítica de carvão ativado dos tubos, perfazendo assim seis frascos com cada volume citado. Estes foram fechados e selados e colocados em freezer a $-20^{\circ} \mathrm{C}$ por 24 horas com intuito de estabilização. Após este tempo foi realizada a dessorção através de $1 \mathrm{~mL}$ de dissulfeto de carbono e análise no espectrômetro de massas.

Também foi realizada prova em branco nas camadas analíticas de carvão ativado.

\section{4 - Pontos de coleta de amostras}

Foram coletadas 54 amostras no período de 18 de novembro a 18 de dezembro de 2002, sendo que 30 amostras foram coletadas em escritórios e 24 amostras foram coletadas no ar externo aos sistemas de condicionamento de ar.

Abaixo estão relacionados os pontos de coleta de amostra (escritórios) por tipo de condicionador de ar, com suas características físicas internas, localização, datas das coletas de amostras bem como o número atribuído as amostras (identificação): 


\section{Ambientes com Condicionador de ar de janela}

* Escritório do Serviço de Segurança do Trabalho (SEST) de uma empresa, Rua Maria Antonia, Vila Buarque, $1^{\circ}$ andar, porém os fundos do escritório, onde está localizado o condicionador de ar, estão para Rua da Consolação. Características físicas: piso de PVC encerado, área de $20 \mathrm{~m}^{2}$, 5 mesas de escritório revestidas de fórmica, 2 armários revestidos de fórmica, dois computadores (CPU e monitor), 1 impressora jato de tinta, 1 máquina de escrever elétrica, paredes pintadas com tinta a base de PVA, uma porta padrão pintada com tinta óleo que permanece aberta durante o dia de trabalho, 1 janela de madeira pintada com tinta óleo que fica com os vidros abaixados permitindo apenas a passagem de luz e 1 janela com esquadria de alumínio basculante que permanece semi aberta para renovação do ar. Foram coletadas 2 amostras deste escritório em 18/11 $\left(n^{\circ} 2\right)$ e 04/12 (n²6).

Departamento de Recursos Humanos de uma empresa, setor de Seleção de Pessoal, Rua Maria Antonia, Vila Buarque, $1^{\circ}$ andar. Características físicas: piso de PVC encerado, área de $30 \mathrm{~m}^{2}, 3$ mesas de escritório revestidas de fórmica, 2 arquivos metálicos, 1 armário de madeira revestido de fórmica, 2 computadores (CPU e monitor), 1 impressora jato de tinta, paredes pintadas com tinta a base de PVA, 1 porta padrão pintada com tinta óleo que permanece aberta durante o dia de trabalho, 1 janela de madeira pintada com tinta óleo que fica com os vidros abaixados permitindo apenas a passagem de luz. Foi coletada 1 amostra deste escritório em 18/11 (n $\left.{ }^{\circ} 4\right)$. Renovação de ar apenas pela porta.

Escritório das secretárias da Diretoria de um Colégio com frente para Rua Itambé e fundos para Rua Piauí (esquina destas ruas), $1^{\circ}$ andar, bairro de Higienópolis. Características físicas: piso de madeira encerado, área de 25 $\mathrm{m}^{2}, 2$ mesas de escritório revestidas de fórmica, 1 estante de madeira envernizada com grande quantidade de livros, dois computadores (CPU e monitor), 1 impressora jato de tinta, 1 aparelho de fax, paredes pintadas com tinta a base de PVA, 2 portas padrão pintadas com tinta óleo sendo 
uma com mola automática e outra que permanece aberta durante o dia de trabalho, 2 janelas de madeira pintadas com tinta óleo que ficam com os vidros abaixados permitindo apenas a passagem de luz quando o condicionador de ar está ligado. Foram coletadas 3 amostras deste escritório em 27/11 (nº 17), 11/12 (n³7) e 18/12 (nº4).

\section{Ambientes com Condicionador de ar de médio porte tipo SPLIT}

Departamento de Recursos Humanos de uma empresa, setor de Folha de Pagamento, Rua Maria Antonia, Vila Buarque, $1^{\circ}$ andar. Características físicas: piso de PVC encerado, área de $150 \mathrm{~m}^{2}, 9$ mesas de escritório revestidas de fórmica, 2 armários de madeira revestidos com fórmica, 12 armários suspensos embutidos na parede e revestidos de fórmica, grande quantidade de papel diariamente, 6 computadores (CPU e monitor), 2 impressoras jato de tinta, 1 impressora laser, paredes pintadas com tinta a base de PVA, não há porta que restrinja a passagem, 2 janelas de madeira pintadas com tinta óleo das quais uma fica com os vidros semi abertos para renovação do ar. Foram coletadas 2 amostras deste escritório em $18 / 11\left(n^{\circ} 5\right)$ e $18 / 12\left(n^{\circ} 51\right)$.

- Secretaria de uma faculdade de administração de empresas, andar térreo de um edifício de 10 andares com frente para Rua Maria Borbae fundos para Rua Amaral Gurgel e Elevado Costa e Silva, Vila Buarque. Características físicas: piso de PVC encerado, área de $20 \mathrm{~m}^{2}, 4$ mesas de escritório revestidas de fórmica, 1 estante de madeira revestida de fórmica com grande quantidade de papéis, dois computadores (CPU e monitor), 1 impressora jato de tinta, paredes pintadas com tinta a base de PVA, 1 porta padrão pintada com tinta óleo com mola automática, sem janelas, apenas com uma abertura na parede em forma de balcão com $1 \mathrm{~m}^{2}$. Foram coletadas 3 amostras deste escritório em 27/11 ( $\left.n^{\circ} 12\right), 11 / 12\left(n^{\circ} 28\right)$ e $18 / 12\left(n^{\circ} 43\right)$.

* Secretaria de uma faculdade de psicologia localizada no centro geográfico de um campus universitário, sendo que este campus é delimitado pelas 
ruas: da Consolação, Maria Antonia, Piauí e Itambé. Características físicas: piso de PVC encerado, área de $50 \mathrm{~m}^{2}, 3$ mesas de escritório revestidas de fórmica, 1 estante de madeira envernizada com grande quantidade de papéis, 1 aparelho de fax, 3 computadores (CPU e monitor), 1 impressora jato de tinta, paredes pintadas com tinta a base de PVA, 1 balcão com abertura de $5 \mathrm{~m}^{2}$ para atendimento ao público e também com função secundária de entrada de ar pois a porta padrão do local possui mola automática. Foram coletadas 3 amostras desta secretaria em 27/11 (nº 19$), 11 / 12\left(n^{\circ} 39\right)$ e 18/12 (no 47$)$.

Escritório dos secretários de uma faculdade de educação, sobrado com frente para Rua Maria Borba e fundos para Rua Amaral Gurgel e Elevado Costa e Silva, Vila Buarque. Características físicas: piso de PVC encerado, área de $25 \mathrm{~m}^{2}, 3$ mesas de escritório revestidas de fórmica, 3 computadores (CPU e monitor), 3 impressoras jato de tinta, paredes pintadas com tinta a base de PVA, uma porta padrão revestida de fórmica com mola automática, 3 janelas de madeira pintada envernizadas que ficam com os vidros fechados permitindo apenas a passagem de luz. Foram coletadas 3 amostras deste escritório em 27/11 (n¹3), 10/12 (n³5) e $18 / 12\left(n^{\circ} 45\right)$. Renovação de ar apenas pela porta.

Importante ressaltar que todos os escritórios amostrados com condicionadores de ar de médio porte e de janela não possuíam renovação de ar por intermédio do equipamento.

\section{Ambientes com Condicionador de ar central}

Escritório do setor de auditoria de uma empresa, $9^{\circ}$ andar, edifício com nove andares, Rua Maria Borba, porém nos fundos do edificio onde há a captação de ar do condicionador ficam a Rua da Consolação e o início do Elevado Costa e Silva. Características físicas: piso de PVC encerado, área de $20 \mathrm{~m}^{2}, 4$ mesas de escritório revestidas de fórmica, 4 computadores (CPU e monitor), 2 impressoras jato de tinta, 1 aparelho de fax, paredes 
pintadas com tinta a base de PVA, uma porta padrão pintada com tinta óleo, 3 janelas de alumínio que ficam com os vidros fechados permitindo apenas a passagem de luz, 1 máquina de xerox, 1 estante de madeira encerada com grande quantidade de papel, 2 armários de madeira revestido de fórmica. Foram coletadas 3 amostras deste escritório em $27 / 11 \quad\left(\mathrm{n}^{\circ} 15\right), 10 / 12 \quad\left(\mathrm{n}^{\circ} 33\right)$ e $11 / 12 \quad\left(\mathrm{n}^{\circ} 41\right)$. Praticamente, quem proporciona a circulação de e renovação de ar é o sistema de condicionamento de ar.

Secretaria dos cursos de pós-graduação de uma universidade, $1^{\circ}$ andar, edifício com 10 andares, Rua da Consolação, Consolação. Características físicas: piso de PVC encerado, área de $100 \mathrm{~m}^{2}, 6$ mesas de escritório revestidas de fórmica, 5 computadores (CPU e monitor), 2 impressoras jato de tinta, 1 impressora a laser, paredes pintadas com tinta a base de PVA, uma porta padrão envernizada, 3 janelas de alumínio que ficam com os vidros fechados permitindo apenas a passagem de luz. 2 estantes de madeira envernizadas com grande quantidade de papel, 3 armários de madeira revestido de fórmica, grande quantidade papel circulante, 1 aparelho de fax, 1 máquina de xerox, balcão para atendimento ao público com $6 \mathrm{~m}^{2}$. Foi coletada 1 amostra desta secretaria em 19/11 ( $\left.\mathrm{n}^{\circ} 7\right)$.

Escritório da coordenação de pós-graduação de uma universidade, $7^{\circ}$ andar, edifício com 10 andares, Rua da Consolação, Consolação. Características físicas: piso de PVC encerado, área de $70 \mathrm{~m}^{2}, 4$ mesas de escritório revestidas de fórmica, 4 computadores (CPU e monitor), 3 impressoras jato de tinta, 1 máquina de xerox, 1 aparelho de fax, paredes pintadas com tinta a base de PVA, uma porta de vidro para entrada no setor a qual permanece fechada, 3 janelas de alumínio que ficam com os vidros fechados permitindo apenas a passagem de luz. 3 estantes de madeira envernizadas com grande quantidade de papel, 4 armários de madeira revestido de fórmica, grande quantidade papel circulante, 1 máquina de xerox, 2 arquivos de metal. Foram coletadas 2 amostras deste escritório em 19/11 (nº) e 18/12 (nº53). 
- Escritório das secretárias de diretores de uma empresa, $10^{\circ}$ andar, edifício com 10 andares, Rua da Consolação, Consolação. Características físicas: piso com carpete de $6 \mathrm{~mm}$, área de $200 \mathrm{~m}^{2}, 3$ mesas de escritório revestidas de fórmica, 3 computadores (CPU e monitor), 3 impressoras jato de tinta, 1 impressora a laser, paredes pintadas com tinta a base de PVA, uma porta de vidro com mola automática, 5 janelas de alumínio que ficam com os vidros fechados permitindo apenas a passagem de luz. 5 estantes de madeira envernizadas com grande quantidade de papel, 5 armários de madeira envernizados, 1 máquina de xerox, 1 aparelho de fax. Foram coletadas 2 amostras deste escritório em 19/11 (n $\left.\mathrm{n}^{\circ} 9\right)$ e 18/12 $\left(\mathrm{n}^{\circ} 54\right)$.

- Escritório da diretoria de um centro de pesquisa em radioastronomia, $1^{\circ}$ andar, edifício de 2 andares, localizado dentro de um campus universitário com distância de 50 metros do edifício até a Rua da Consolação. Características fisicas: piso de PVC encerado, área de $16 \mathrm{~m}^{2}, 1$ mesa de escritório revestida de fórmica, 1 computador (CPU e monitor), 1 impressoras jato de tinta, paredes pintadas com tinta a base de PVA, uma porta padrão revestida de fórmica, divisórias de vidro e eucatex, 1 janela de alumínio que fica com os vidros fechados permitindo apenas a passagem de luz, 2 armários de madeira revestido de fórmica, 1 aparelho de fax. Foi coletada 1 amostra deste escritório em 03/12 (n²0).

Escritório da vice-diretoria de um centro de pesquisa em radioastronomia, $1^{\circ}$ andar, edifício de 2 andares, localizado dentro de um campus universitário com distância de 50 metros do edifício até a Rua da Consolação. Características físicas: piso de PVC encerado, área de $5 \mathrm{~m}^{2}$, 1 mesa de escritório revestida de fórmica, 1 computador (CPU e monitor), 1 impressoras jato de tinta, parede pintada com tinta a base de PVA, uma porta padrão revestida de fórmica, divisórias de vidro e eucatex, 1 janela de alumínio que fica com os vidros fechados permitindo apenas a passagem de luz, 2 armários de madeira revestido de fórmica, 1 arquivo de metal. Foram coletadas 3 amostras deste escritório em 03/12 (n²3), $04 / 12\left(n^{\circ} 24\right)$ e $10 / 12\left(n^{\circ} 31\right)$. 
Escritório de pesquisadores de um centro de pesquisa em radioastronomia, $1^{\circ}$ andar, edifício de 2 andares, localizado dentro de um campus universitário com distância de 50 metros do edifício até a Rua da Consolação. Caracteristicas físicas: piso de PVC encerado, área de $10 \mathrm{~m}^{2}$, 2 mesas de escritório revestidas de fórmica, 2 computadores (CPU e monitor), 1 impressora jato de tinta, paredes pintadas com tinta a base de PVA, uma porta padrão revestida de fórmica, divisórias de vidro e madeira prensada, 1 janela de alumínio que fica com os semi abertos para renovação de ar, 1 estante metálica com grande quantidade de papel. Foi coletada 1 amostra deste escritório em 03/12 (n²2).

\section{Ambientes externos}

Descrevem-se a seguir os pontos de coleta de amostras do ar externo aos ambientes:

Fundos do escritório do Serviço de Segurança do Trabalho (SEST) de uma empresa, que fica na Rua Maria Antonia, Vila Buarque, $1^{\circ}$ andar, porém a captação de ar fica voltada para Rua da Consolação. Foram coletadas 2 amostras em 18/11 ( $\left.{ }^{\circ} 1\right)$ e 04/12 (n²9).

Frente dos escritórios dos setores de Seleção de Pessoal e Folha de Pagamento de uma empresa na Rua Maria Antonia. Foram coletadas 2 amostras em 18/11 (n'3) e 18/12 (n'50).

* Casa de máquinas de um edifício administrativo de uma empresa com 10 andares, Rua da Consolação, Consolação, Foram coletadas 2 amostras em 19/11 ( $\left.{ }^{\circ} 6\right)$ e 18/12 (n'52).-

Fundos de um edifício de 10 andares que abriga uma faculdade de administração de empresas, a corrente de ar é provém principalmente da rua Amaral Gurgel e Elevado Costa e Silva. Foram coletadas 3 amostras em 27/11 ( $\left.n^{\circ} 10\right), 04 / 12\left(n^{\circ} 28\right)$ e 11/12 (n'42).

- Fundos de um sobrado onde funciona o escritório dos secretários da diretoria de uma faculdade de educação na Rua Maria Borba, Vila 
Buarque. Foram coletadas 3 amostras em 27/11 (n¹1), 10/12 (n $\left.\mathrm{n}^{\circ} 34\right)$ e $11 / 12\left(n^{\circ} 44\right)$.

* Casa de máquinas de um edifício de nove andares, especificamente o nono andar, setor de auditoria de uma empresa, Rua Maria Borba, porém a captação de ar está voltada para Rua da Consolação e início do Elevado Costa e Silva. Foram coletadas 3 amostras em 27/11 (n¹4), 10/12 (n³2) e $11 / 12\left(n^{\circ} 40\right)$.

* Fundos do escritório das secretárias da Diretoria de um Colégio, bairro de Higienópolis. A captação do ar provém principalmente da esquina das ruas Piauí e Itambé. Foram coletadas 3 amostras em 27/11 (nº), 11/12 $\left(n^{\circ} 36\right)$ e $18 / 12\left(n^{\circ} 48\right)$.

* Centro geográfico de um campus situado no perímetro entre as ruas da Consolação, Maria Antonia, Itambé e Piauí. A captação de ar pertence à secretaria de uma faculdade de psicologia desta universidade, sendo esta captação é dentro de um pequeno bosque ao lado de uma biblioteca. Foram coletadas 3 amostras em 27/11 ( $\left.{ }^{\circ} 18\right), 11 / 12\left(n^{\circ} 38\right)$ e 18/12 (no 46$)$.

- Teto (laje), edifício de 2 andares, localizado dentro de um campus universitário com distância de 50 metros do edifício até a Rua da Consolação, sendo a captação de ar para refrigerar um centro de pesquisas em radioastronomia voltada esta para rua da Consolação.

Todos os escritórios amostrados com ar condicionado central possuíam uma renovação de ar propiciada pelo equipamento de 15 a $25 \%$.

\section{5- Avaliação estatística das amostras}

Para esta avaliação utilizou-se a análise de variância (ANOVA) com valor de $p$ de 0,05 de significância estatística.

A avaliação tomou por base os resultados obtidos nas análises tanto do ar interno como externo com intuito de verificação da significância estatística dos resultados das amostras entre os três tipos de condicionador de ar. 


\section{4- RESULTADOS e DISCUSSÕES}

\section{1-Validação baseada no critério NIOSH para o Método Analítico}

\subsection{1- Limite de Deteç̧ão do Método Analítico}

Foram utilizados para análise os padrões citados no item 3.1.2.2; estes foram injetados por seis vezes. Para as áreas obtidas foram calculadas as médias aritméticas de cada substância e a média para cada padrão.

Seguem as tabelas com as análises e gráficos de concentração "versus" área além do $r^{2}$ das retas obtidas.

Tabela 8- Dados para cálculo do limite de detecção do Tetracloreto de Carbono

\begin{tabular}{c|c|c}
\hline $\begin{array}{c}\text { Padrão } \\
\text { (Micrograma) }\end{array}$ & $\begin{array}{c}\text { Áreas obtidas } \\
\text { Média de seis injeções }\end{array}$ & Áreas calculadas \\
\hline 0,0318 & 3985211 & 3065158 \\
0,0159 & 1958222 & 1475158 \\
0,0080 & 652159 & 685158 \\
0,0008 & 125122 & 131158 \\
\hline
\end{tabular}




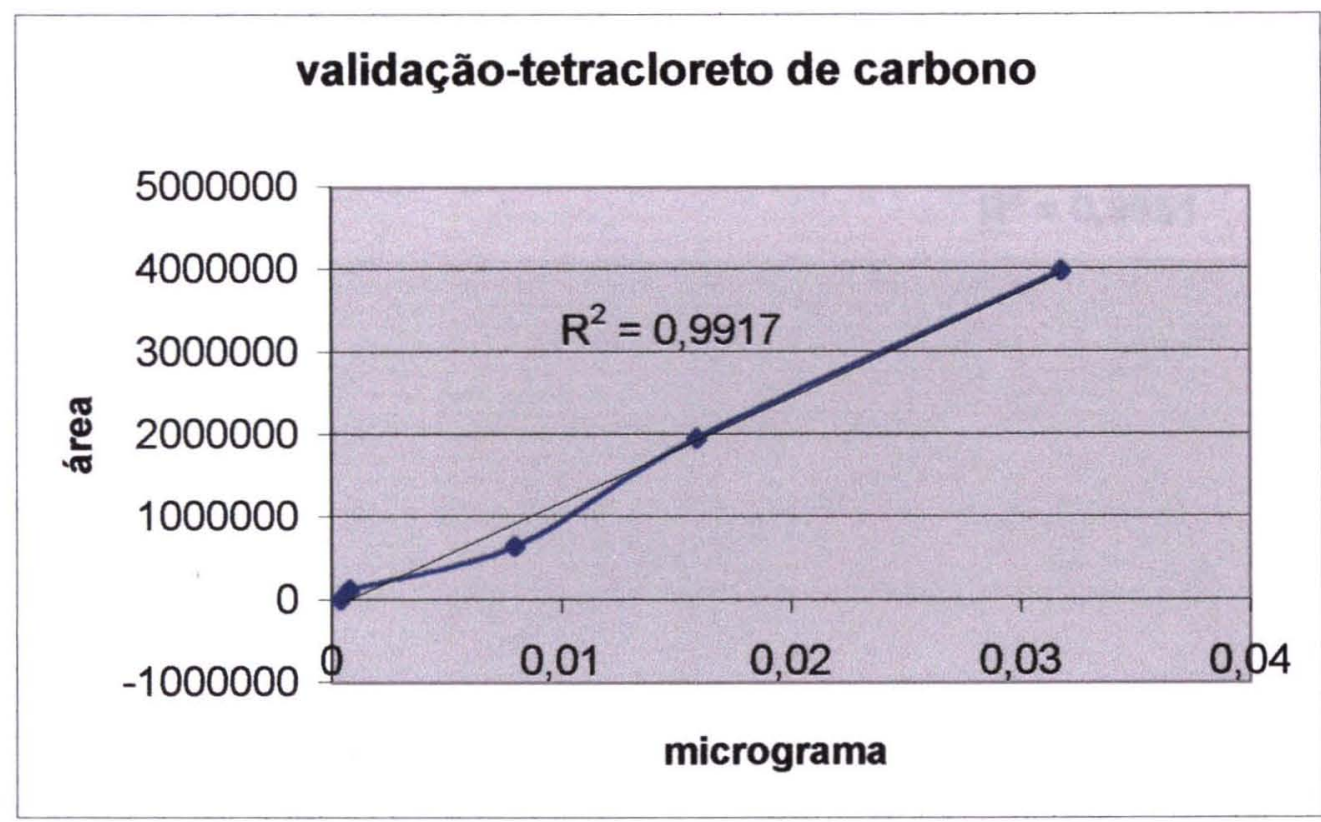

Figura 1- Área "versus" micrograma de Tetracloreto de Carbono para cálculo do limite de detecção

Tabela 9- Dados para cálculo do limite de deteç̧ão do Clorofórmio

\begin{tabular}{c|c|c}
\hline $\begin{array}{c}\text { Padrão } \\
\text { (Micrograma) }\end{array}$ & $\begin{array}{c}\text { Áreas obtidas } \\
\text { Média de seis injeções }\end{array}$ & Áreas calculadas \\
\hline 0,0300 & 512001 & 610898 \\
0,0150 & 285001 & 310898 \\
0,0075 & 154023 & 160898 \\
0,0008 & 15231 & 26898 \\
\hline
\end{tabular}




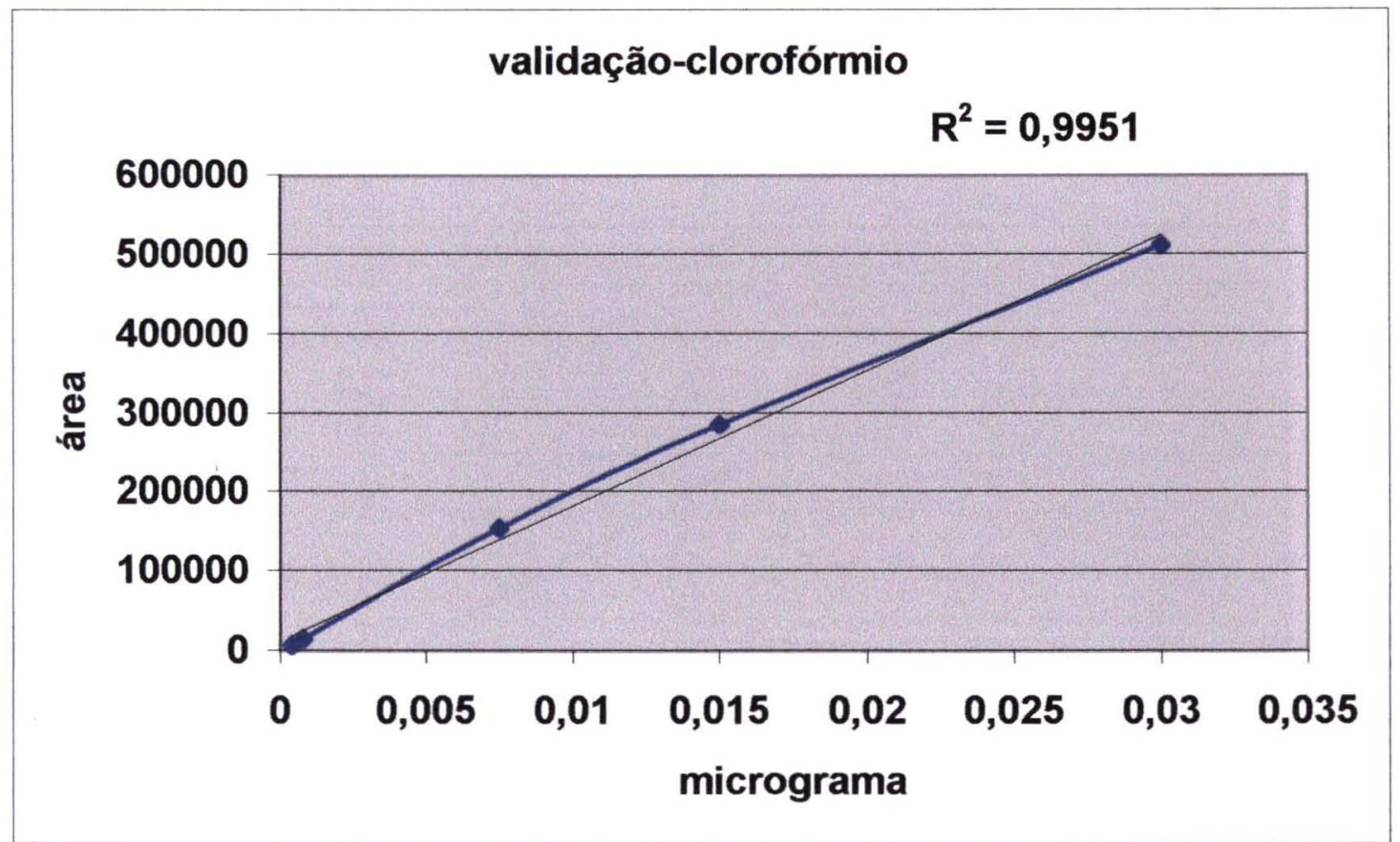

Figura 2- Área "versus" micrograma de Clorofórmio para cálculo do limite de detecção

Tabela 10- Dados para cálculo do limite de detecção do Benzeno

\begin{tabular}{c|c|c}
\hline $\begin{array}{c}\text { Padrão } \\
\text { (Micrograma) }\end{array}$ & $\begin{array}{c}\text { Áreas obtidas } \\
\text { Média de seis injeções }\end{array}$ & Áreas calculadas \\
\hline 0,0176 & 8970111 & 9017407 \\
0,0088 & 4661381 & 4632912 \\
0,0044 & 2577085 & 2440665 \\
0,0004 & 501923 & 467643 \\
0,0002 & 206161 & 358030 \\
\hline
\end{tabular}




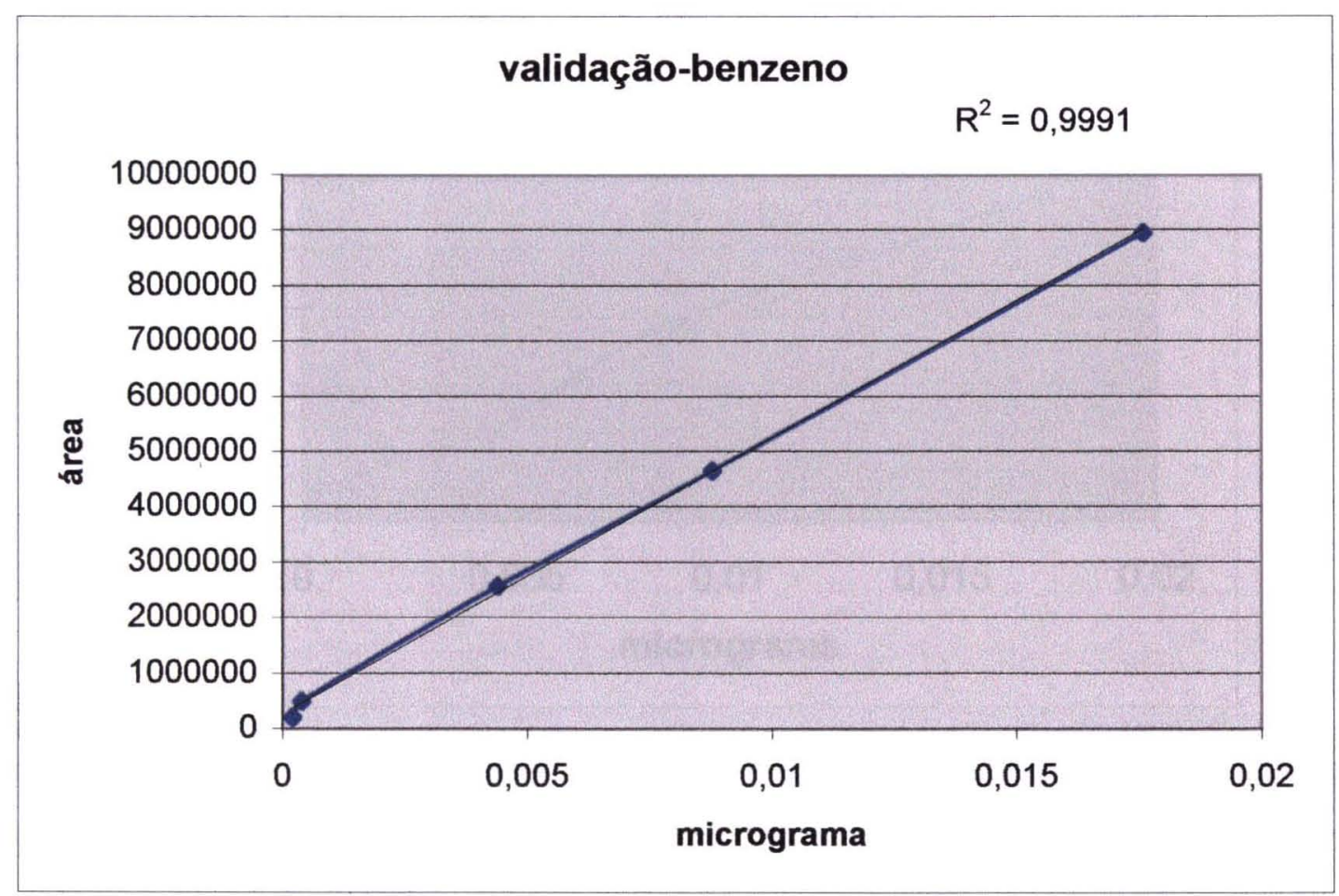

Figura 3- Área "versus" micrograma de Benzeno para cálculo do limite de detecção.

Tabela 11- Dados para cálculo do limite de detecção do Tolueno

\begin{tabular}{c|c|c}
\hline $\begin{array}{c}\text { Padrão } \\
\text { (Micrograma) }\end{array}$ & $\begin{array}{c}\text { Áreas obtidas } \\
\text { Média de seis injeções }\end{array}$ & Áreas calculadas \\
\hline 0,0174 & 4815446 & 5560688 \\
0,0087 & 2930083 & 2950688 \\
0,0044 & 815172 & 1660688 \\
0,0004 & 491458 & 460688 \\
0,0002 & 310547 & 400688 \\
\hline
\end{tabular}




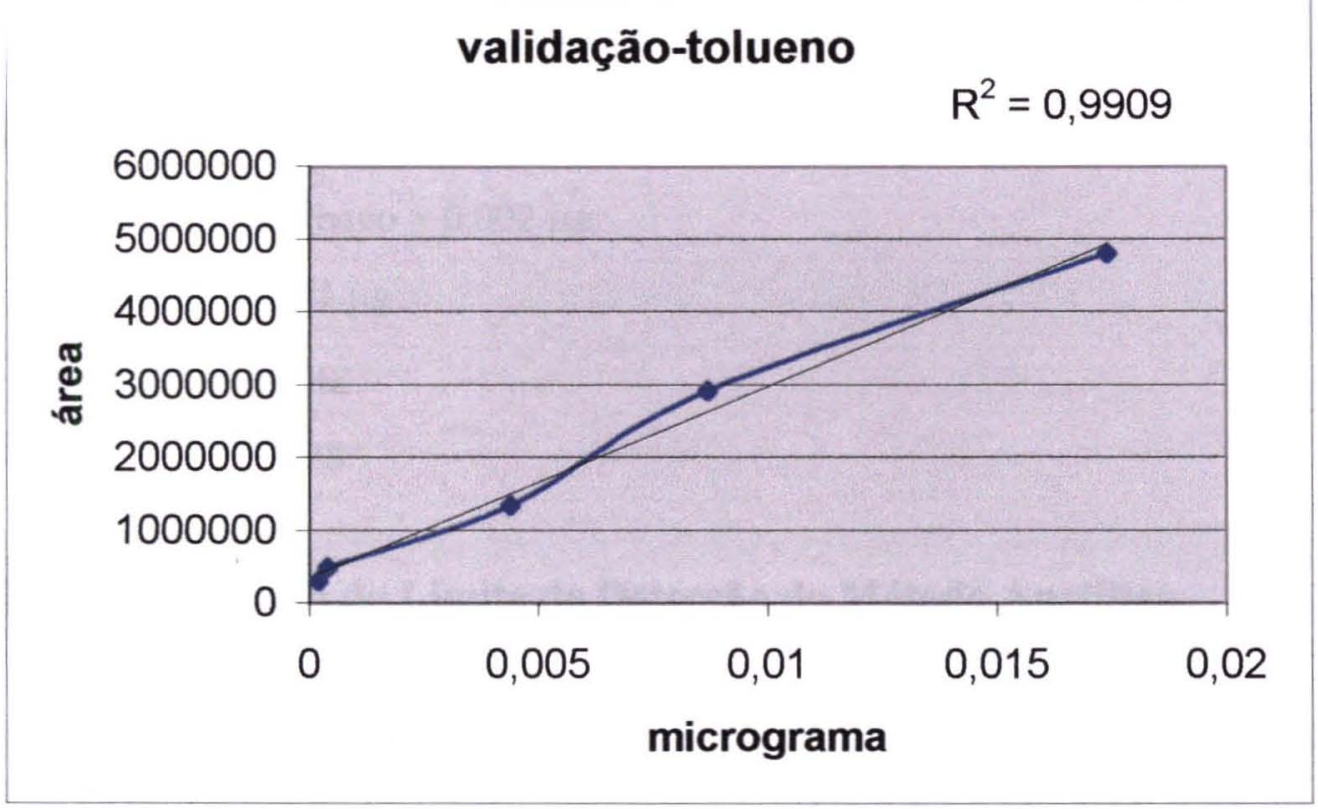

Figura 4- Área "versus" micrograma de Tolueno para cálculo do limite de detecção

A seguir são apresentadas as fórmulas para o cálculo dos Limites de Detecção para Tetracloreto de Carbono, Clorofórmio, Benzeno e Tolueno:

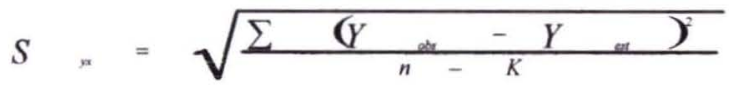

Onde:

$\mathrm{S}_{\mathrm{yx}}=$ erro padrão da estimativa para o Limite de Detecção

$\mathrm{Y}_{\mathrm{obs}}=$ área observada

$\mathrm{Y}_{\text {est }}=$ área estimada na regressão da curva

$\mathrm{n}=$ número total de pontos na curva

$\mathrm{K}=$ considerar 2 para regressão linear

Portanto como citado no item 3.1.3.1, se o erro padrão da estimativa de uma reta $S_{\mathrm{yx}}$, é o equivalente matemático do desvio padrão para dados tabulados (NIOSH,1998), a fórmula para cálculo final do Limite de Deteç̧ão fica: 


$$
L_{D}=3 S_{y x}
$$

Os Limites de Detecção calculados mediante os testes realizados foram:

Tetracloreto de Carbono $=0,002 \mu \mathrm{g}$

Clorofórmio $=0,001 \mu \mathrm{g}$

Benzeno $=0,0002 \mu \mathrm{g}$

Tolueno $=0,0005 \mu \mathrm{g}$

\subsubsection{1- Discussão do Limite de Deteç̧ão do Método Analítico}

Para os Limites de Detecção do Método Analítico das substâncias tetracloreto de carbono, clorofórmio, benzeno e tolueno, os valores de $\mathrm{R}^{2}$ encontrados nos gráficos foram 0,99; valores estes adequados segundo o critério NIOSH. Porém, os valores nominais dos Limites de Deteç̧ão encontrados foram os valores os mesmos das análises, principalmente de benzeno e tetracloreto de carbono. Sendo que no caso do clorofórmio, as análises nem chegaram ao Limite de Deteç̧ão e para o tolueno ficaram superiores ao Limite de Detecção, ou seja, trabalhamos analiticamente com amostras ambientais próximas ou dentro do Limite de Detecção das substâncias em quase todas as amostras, sendo que as curvas de calibração eram praticamente as mesmas do estudo de Limite de Detecção.

\subsection{2- Precisão e Recuperação do Método Analítico}

Para estudos de precisão e recuperação do método analítico foram preparadas soluções que simularam três massas de tetracloreto de carbono, clorofórmio, benzeno e tolueno que poderiam ser amostradas nos locais determinados como pontos de amostra.

A seguir as massas preparadas e analisadas:

* 0,$20 ; 0,30$ e $0,40 \mu \mathrm{g}$ de tetracloreto de carbono,

* 0,$19 ; 0,29$ e $0,38 \mu \mathrm{g}$ de clorofórmio,

0,$22 ; 1,20$ e $2,20 \mu \mathrm{g}$ de benzeno e

* 4,$35 ; 6,53$ e $8,70 \mu \mathrm{g}$ de tolueno. 
Para os testes de precisão do método foram realizadas três experiências com cada substância sendo que em cada experiência analisamos uma mesma massa da substância seis vezes conforme preconiza a metodologia NIOSH (1998).

\subsubsection{1- Cálculos utilizados para determinação da Precisão e Recuperação do método}

Média: média aritmética $\bar{x}$, definida como a soma das observações pelo número de observações (n).

$$
-\sum_{x=1}^{n} x_{i}
$$

Desvio Padrão (S): Raiz quadrada da variança. A qual é definida como soma dos quadrados dos desvios das observações da média dividida pelo número de observações menos 1 (n-1).

$(S)=\sqrt{\frac{\sum_{i=1}^{n}\left(x_{i}-\bar{x}\right)^{2}}{n-1}}$

Coeficiente de variação (Cv): ou desvio - padrão relativo, definido como o desvio - padrão dividido pela média relativo às seis análises

$$
C v=\frac{s}{-}
$$

Coeficiente de variação total (CV): "pool" de coeficientes de variação originários dos $\mathrm{Cv}$ obtidos nas análises de soluções com concentrações conhecidas. 
$C V=\sqrt{\frac{\sum_{i=1}^{3} \phi_{i}\left(C v_{i}\right)^{2}}{\phi}}$

Onde:

$\phi_{i}=$ Grau de liberdade igual ao número de observações $\left(n_{\mathrm{i}}\right)$ menos 1 , até o

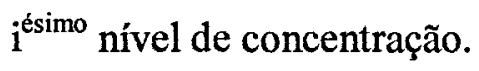

$C v_{i}=$ Coeficiente de variação ( $\mathrm{Cv}$ das análises) das observações ao iésimo nível de concentração

$\phi=$ somatória dos graus de liberdade

Para calcularmos a Precisão e Recuperação do método analítico utilizamos as Tabelas 12 a 20 . 
Tabela 12- Teste de precisão para Tetracloreto de Carbono

\begin{tabular}{|c|c|c|c|}
\hline Experiência & $\begin{array}{c}\text { Massa encontrada } \\
(\mu \mathrm{g})\end{array}$ & $\begin{array}{c}\text { Massa média } \\
\text { encontrada }(\mu \mathrm{g})\end{array}$ & $\begin{array}{c}\text { Estimativa do desvio } \\
\text { padrão da média }\end{array}$ \\
\hline & 0,18 & & \\
\hline & 0,18 & & \\
\hline \multirow[t]{6}{*}{1} & 0,20 & 0,19 & 0,01 \\
\hline & 0,19 & & \\
\hline & 0,17 & & \\
\hline & 0,19 & & \\
\hline & 0,28 & & \\
\hline & 0,28 & & \\
\hline \multirow[t]{6}{*}{2} & 0,29 & 0,28 & $<0,01$ \\
\hline & 0,27 & & \\
\hline & 0,27 & & \\
\hline & 0,27 & & \\
\hline & 0,39 & & \\
\hline & 0,37 & & \\
\hline \multirow[t]{4}{*}{3} & 0,37 & 0,38 & $<0,01$ \\
\hline & 0,40 & & \\
\hline & 0,39 & & \\
\hline & 0,37 & & \\
\hline
\end{tabular}


Tabela 13- Teste de precisão para clorofórmio

\begin{tabular}{|c|c|c|c|}
\hline Experiência & $\begin{array}{c}\text { Massa encontrada } \\
(\mu \mathrm{g})\end{array}$ & $\begin{array}{c}\text { Massa média } \\
\text { encontrada }(\mu \mathrm{g})\end{array}$ & $\begin{array}{c}\text { Estimativa do desvio } \\
\text { padrão da média }\end{array}$ \\
\hline & 0,16 & & \\
\hline & 0,16 & & \\
\hline \multirow[t]{6}{*}{1} & 0,18 & 0,17 & 0,01 \\
\hline & 0,17 & & \\
\hline & 0,16 & & \\
\hline & 0,17 & & \\
\hline & 0,26 & & \\
\hline & 0,26 & & \\
\hline \multirow[t]{6}{*}{2} & 0,28 & 0,27 & $<0,01$ \\
\hline & 0,27 & & \\
\hline & 0,27 & & \\
\hline & 0,27 & & \\
\hline & 0,37 & & \\
\hline & 0,36 & & \\
\hline \multirow[t]{4}{*}{3} & 0,36 & 0,37 & 0,01 \\
\hline & 0,37 & & \\
\hline & 0,37 & & \\
\hline & 0,37 & & \\
\hline
\end{tabular}


Tabela 14- Teste de precisão para benzeno

\begin{tabular}{|c|c|c|c|}
\hline Experiência & $\begin{array}{c}\text { Massa encontrada } \\
(\mu \mathrm{g})\end{array}$ & $\begin{array}{c}\text { Massa média } \\
\text { encontrada }(\mu \mathrm{g})\end{array}$ & $\begin{array}{c}\text { Estimativa do desvio } \\
\text { padrão da média }\end{array}$ \\
\hline & 0,19 & & \\
\hline & 0,19 & & \\
\hline \multirow[t]{6}{*}{1} & 0,21 & 0,20 & 0,01 \\
\hline & 0,21 & & \\
\hline & 0,21 & & \\
\hline & 0,21 & & \\
\hline & 1,18 & & \\
\hline & 1,19 & & \\
\hline \multirow[t]{6}{*}{2} & 1,19 & 1,19 & 0,01 \\
\hline & 1,19 & & \\
\hline & 1,18 & & \\
\hline & 1,18 & & \\
\hline & 2,18 & & \\
\hline & 2,19 & & \\
\hline \multirow[t]{4}{*}{3} & 2,18 & 2,18 & 0,01 \\
\hline & 2,18 & & \\
\hline & 2,18 & & \\
\hline & 2,19 & & \\
\hline
\end{tabular}


Tabela 15- Teste de precisão para Tolueno

\begin{tabular}{|c|c|c|c|}
\hline Experiência & $\begin{array}{c}\text { Massa encontrada } \\
(\mu \mathrm{g})\end{array}$ & $\begin{array}{c}\text { Massa média } \\
\text { encontrada }(\mu \mathrm{g})\end{array}$ & $\begin{array}{c}\text { Estimativa do desvio } \\
\text { padrão da média }\end{array}$ \\
\hline \multirow{6}{*}{1} & 4,31 & \multirow{6}{*}{4,31} & \multirow{6}{*}{0,01} \\
\hline & 4,31 & & \\
\hline & 4,30 & & \\
\hline & 4,30 & & \\
\hline & 4,31 & & \\
\hline & 4,30 & & \\
\hline \multirow{6}{*}{2} & 6,52 & \multirow{6}{*}{6,52} & \multirow{6}{*}{$<0,01$} \\
\hline & 6,50 & & \\
\hline & 6,52 & & \\
\hline & 6,51 & & \\
\hline & 6,53 & & \\
\hline & 6,53 & & \\
\hline \multirow{6}{*}{3} & 8,64 & \multirow{6}{*}{8,63} & \multirow{6}{*}{0,01} \\
\hline & 8,60 & & \\
\hline & 8,65 & & \\
\hline & 8,64 & & \\
\hline & 8,62 & & \\
\hline & 8,60 & & \\
\hline
\end{tabular}

A Tabela 16 mostra os Coeficientes de Variação (Cv) obtidos nas experiências de cada substância. 
Tabela 16- Resultados dos Coeficientes de Variação (Cv) das substâncias por experiência

\begin{tabular}{lcccc}
\hline & $\mathbf{C C l}_{\mathbf{4}}$ & $\mathbf{H C C l}_{\mathbf{3}}$ & Benzeno & Tolueno \\
\hline Experiência 1 & 0,053 & 0,053 & 0,045 & 0,002 \\
Experiência 2 & 0,032 & 0,015 & 0,008 & 0,001 \\
Experiência 3 & 0,011 & 0,024 & 0,004 & 0,001 \\
\hline
\end{tabular}

As Tabelas 17 a 20 mostram os resultados dos testes de recuperação.

Tabela 17- Teste de recuperação do método para Tetracloreto de Carbono

\begin{tabular}{ccc}
\hline $\begin{array}{c}\text { Massa da solução } \\
(\mu \mathrm{g})\end{array}$ & $\begin{array}{c}\text { Massa média encontrada } \\
(\mu \mathrm{g})\end{array}$ & $\begin{array}{c}\text { Recuperação } \\
(\%)\end{array}$ \\
\hline 0,20 & 0,19 & 95 \\
0,30 & 0,28 & 93 \\
0,40 & 0,38 & 95 \\
\hline
\end{tabular}

Tabela 18- Teste de recuperação do método para Clorofórmio

\begin{tabular}{ccc}
\hline $\begin{array}{c}\text { Massa da solução } \\
(\mu \mathrm{g})\end{array}$ & $\begin{array}{c}\text { Massa média encontrada } \\
(\mu \mathrm{g})\end{array}$ & $\begin{array}{c}\text { Recuperação } \\
(\%)\end{array}$ \\
\hline 0,19 & 0,17 & 90 \\
0,29 & 0,27 & 93 \\
0,38 & 0,37 & 97 \\
\hline
\end{tabular}


Tabela 19- Teste para recuperação do método para Benzeno

\begin{tabular}{ccc}
\hline $\begin{array}{c}\text { Massa da solução } \\
(\mu \mathrm{g})\end{array}$ & $\begin{array}{c}\text { Massa média encontrada } \\
(\mu \mathrm{g})\end{array}$ & $\begin{array}{c}\text { Recuperação } \\
(\%)\end{array}$ \\
\hline 0,22 & 0,20 & 91 \\
1,20 & 1,19 & 99 \\
2,20 & 2,18 & 99 \\
\hline
\end{tabular}

Tabela 20- Teste de recuperação do método para Tolueno

\begin{tabular}{ccc}
\hline $\begin{array}{c}\text { Massa da solução } \\
(\mu \mathrm{g})\end{array}$ & $\begin{array}{c}\text { Massa média encontrada } \\
(\mu \mathrm{g})\end{array}$ & $\begin{array}{c}\text { Recuperação } \\
(\%)\end{array}$ \\
\hline 4,35 & 4,31 & 99 \\
6,53 & 6,52 & 99 \\
8,70 & 8,63 & 99 \\
\hline
\end{tabular}

\subsubsection{2 - Discussão sobre Precisão e Recuperação do Método Analítico}

No estudo de Precisão e Recuperação do Método Analítico, os CV Totais ( coeficientes de variação totais) obtidos foram:
- Tetracloreto de Carbono
$\mathrm{CV}=0,036$
Clorofórmio
$\mathrm{CV}=0,035$
- Benzeno
$\mathrm{CV}=0,026$
Tolueno
$\mathrm{CV}=0,001$

Estes estão dentro do critério NIOSH onde é preconizado que o valor para o coeficiente de variação dentro de um grau de liberdade 15 , deve estar acima de 0,105. No teste de Recuperação do Método Analítico todas as substâncias apresentaram valores acima de $90 \%$ de recuperação. 


\section{2- Validação do método de coleta}

Foram analisados em cada período, seis tubos do tipo SKC 226-01 com 100 mg de carvão ativado derivado de côco como camada analítica e $50 \mathrm{mg}$ na camada controle conforme referenciado pela NIOSH, OSHA e Supelco.

Tabela 21- Áreas médias de seis análises de tubos de cada substância por períodos de amostragem

\begin{tabular}{|c|c|c|c|c|c|c|}
\hline & 1h $2 h 3 h$ & $4 h$ & $6 h$ & $8 h$ & $9 \mathrm{~h}$ & $10 \mathrm{~h}$ \\
\hline $\mathrm{CCl}_{4}$ & nd nd nd & 9727 & 60258 & 72052 & 110239 & 102165 \\
\hline $\mathrm{HCCl}_{3}$ & nd nd nd & nd & 2139 & 2309 & 3833 & 1051 \\
\hline Benzeno & nd nd nd & 332135 & 512738 & 686759 & 865978 & 714961 \\
\hline Tolueno & nd nd nd & 903442 & 2018681 & 5507423 & 11223644 & 10874463 \\
\hline
\end{tabular}

O período onde ocorreu a estabilização/diminuição das áreas obtidas foi em 10 horas, assim o período limite para coleta de amostras foi estipulado em 9 horas. Para este tempo de coleta de 9 horas foram calculados também os desvios padrão dos resultados das análises das amostras e o coeficiente de variação ou desvio padrão médio.

A Tabela 22 mostra os resultados das análises dos tubos utilizados no teste de 9 horas para levantamento do tempo de amostragem. 
Tabela 22- Resultados em área das análises de tetracloreto de carbono, clorofórmio, benzeno e tolueno por tubo no teste de nove horas de coleta

\begin{tabular}{ccccc}
\hline Tubo & $\mathbf{C C l}_{\mathbf{4}}$ & $\mathbf{H C C l}_{\mathbf{3}}$ & Benzeno & Tolueno \\
\hline $\mathbf{1}$ & 108915 & 3880 & 850121 & 11250122 \\
$\mathbf{2}$ & 108110 & 3812 & 861810 & 11080394 \\
$\mathbf{3}$ & 109825 & 3775 & 880003 & 11622473 \\
$\mathbf{4}$ & 112320 & 3791 & 864110 & 11380190 \\
$\mathbf{5}$ & 110152 & 3892 & 858814 & 11000251 \\
$\mathbf{6}$ & 112114 & 3852 & $\mathbf{8 8 1 0 1 0}$ & 11008433 \\
\hline
\end{tabular}

Mediante os resultados das análises citados e as médias citadas para a coleta de 9 horas obtivemos os seguintes dados de Desvio Padrão e Coeficiente de Variação Médio.

Tabela 23- Resultados de desvio padrão e CV por substância na coleta de nove horas

\begin{tabular}{ccccc}
\hline & $\mathbf{C C l}_{\mathbf{4}}$ & $\mathbf{H C C l}_{\mathbf{3}}$ & Benzeno & Tolueno \\
\hline Desvio Padrão & 1691 & 48,2 & 12217,1 & 245362,2 \\
Coeficiente de & 0,015 & 0,0126 & 0,014 & 0,0219 \\
$\quad$ Variação & & & & \\
\hline
\end{tabular}

\subsection{1- Discussão do método de coleta}

$\mathrm{Na}$ validação do método de coleta utilizado conseguimos estipular o tempo ideal de coleta, pois as referências disponíveis para este tipo de análise (tubo de vidro com carvão ativado) indicavam tempos de amostragem para concentrações em ppm e não se referiam a ppb como no caso esperado de nossas amostras.

A metodologia alternativa para validação do método de coleta indicada pela OSHA (1999) para os casos onde não se consegue gerar atmosferas controladas (arraste de padrão inserido em tubo de vidro, através de ar com $80 \%$ de umidade na 
temperatura de $22^{\circ} \mathrm{C}$ colocando em sequiência o tubo amostrador), mostrou-se pouco realista e reproduzível para concentrações em ppb pois, em testes de laboratório obtivemos valores altos de CV, em torno de 0,3 sendo que o indicado pela OSHA e NIOSH é um valor inferior a $0,106 \mathrm{de} C$.

\section{3- Avaliação do adsorvente e do dessorvedor}

Realizou-se esta avaliação do adsorvente e do dessorvedor para verificar a eficiência na extração das substâncias por parte do dissulfeto de carbono bem como a capacidade de retenção do carvão ativado.

A Tabela 24 mostra as massas efetivas inseridas nas camadas de carvão ativado dos tubos amostradores a partir da Solução Estoque (SL). As Tabelas 25 a 28 mostram a eficiência do processo de extração.

Tabela 24- Massas de substâncias inseridas nos tubos amostradores

\begin{tabular}{cccc}
\hline $\mathbf{C C l}_{\mathbf{4}}(\mu \mathrm{g})$ & $\mathrm{HCCl}_{\mathbf{3}}(\mu \mathrm{g})$ & Benzeno $(\mu \mathrm{g})$ & Tolueno $(\mu \mathrm{g})$ \\
\hline 0,32 & 0,30 & 0,18 & 0,17 \\
0,80 & 0,75 & 0,44 & 0,44 \\
1,59 & 1,50 & 0,88 & 0,87 \\
2,39 & 2,25 & 1,32 & 1,31 \\
3,18 & 3,00 & 1,76 & 1,74 \\
\hline
\end{tabular}

Tabela 25- Eficiência de extração do Tetracloreto de carbono

\begin{tabular}{ccc}
\hline Massa real $(\mu \mathrm{g})$ & Massa média medida $(\mu \mathrm{g})$ & Recolhido \% \\
\hline 0,32 & 0,27 & 84,4 \\
0,80 & 0,69 & 86,3 \\
1,59 & 1,38 & 86,8 \\
2,39 & 2,20 & 92,1 \\
3,18 & 2,95 & 92,8 \\
\hline
\end{tabular}


Tabela 26- Eficiência de extração do Clorofórmio

\begin{tabular}{ccc}
\hline Massa real $(\mu \mathrm{g})$ & Massa média medida $(\mu \mathrm{g})$ & Recolhido \% \\
\hline 0,30 & 0,27 & 90,0 \\
0,75 & 0,71 & 94,7 \\
1,50 & 1,41 & 94,0 \\
2,25 & 2,19 & 97,3 \\
3,00 & 2,92 & 97,3 \\
\hline
\end{tabular}

Tabela 27- Eficiência de extração do Benzeno

\begin{tabular}{ccc}
\hline Massa real $(\mu \mathrm{g})$ & Massa média medida $(\mu \mathrm{g})$ & Recolhido $\%$ \\
\hline 0,18 & 0,18 & 100 \\
0,44 & 0,45 & 102,3 \\
0,88 & 0,87 & 98,9 \\
1,32 & 1,30 & 98,5 \\
1,76 & 1,74 & 98,9 \\
\hline
\end{tabular}

Tabela 28- Eficiência de extração do Tolueno

\begin{tabular}{ccc}
\hline Massa real $(\mu \mathrm{g})$ & Massa média medida $(\mu \mathrm{g})$ & Recolhido $\%$ \\
\hline 0,17 & 0,17 & 100 \\
0,44 & 0,43 & 97,7 \\
0,87 & 0,85 & 97,7 \\
1,31 & 1,28 & 97,7 \\
1,74 & 1,68 & 96,6 \\
\hline
\end{tabular}

\subsection{1- Discussão da avaliação do Adsorvente e do Dessorvedor}

Pela metodologia analítica aplicada conseguimos obter valores razoáveis para Eficiência de Extração das substâncias de interesse do carvão ativado pelo dissulfeto de carbono. O critério NIOSH e também da OSHA preconizam um 
recolhimento de massa adicionada superior a $75 \%$ e de preferência maior que $90 \%$. Os valores obtidos foram quase todos superiores a $90 \%$ com exceção do tetracloreto de carbono que indicou valores próximos a 90\% para massas inferiores a 1,60 $\mu \mathrm{g}$.

\section{4- Medições ambientais}

Foram coletadas amostras no período de 18 de novembro de 2002 a 18 de dezembro 2002. A Tabela 29 mostra as condições ambientais externas existentes nos dias de coleta:

Tabela 29- Condições ambientais por dia de coleta

\begin{tabular}{|c|c|c|c|c|c|}
\hline Dia & $\begin{array}{c}\text { Temp. } \\
\text { inicial }{ }^{\circ} \mathrm{C}(7 \\
\text { a 8h) }\end{array}$ & $\begin{array}{l}\text { Umid. Relat. } \\
\text { Inicial \% (7 a } \\
8 \mathrm{~h})\end{array}$ & $\begin{array}{c}\text { Temp. final } \\
{ }^{\circ} \mathrm{C}(16 \text { a 17h })\end{array}$ & $\begin{array}{c}\text { Umid. Relat. } \\
\text { final \% (16 a } \\
17 \mathrm{~h})\end{array}$ & $\begin{array}{l}\text { Condições } \\
\text { do tempo }\end{array}$ \\
\hline $18 / 11$ & 18 & 85 & 30 & 60 & Ensolarado \\
\hline $19 / 11$ & 19 & 85 & 30 & 62 & Ensolarado \\
\hline $27 / 11$ & 19 & 90 & 31 & 55 & Ensolarado \\
\hline $03 / 12$ & 21 & 88 & 24 & 80 & Nublado \\
\hline $04 / 12$ & 20 & 94 & 32 & 51 & Ensolarado \\
\hline $10 / 12$ & 19 & 89 & 32 & 55 & Ensolarado \\
\hline $11 / 12$ & 18 & 88 & 25 & 73 & Nublado \\
\hline $18 / 12$ & 19 & 90 & 30 & 62 & Ensolarado \\
\hline
\end{tabular}

Não houve chuva nos dias de coleta, mesmo nos dias nublados. O período escolhido foi o início do verão pois os escritórios ativam seus sistemas de condicionamento de ar devido ao calor.

Entre os dias amostrados apenas dois não ficaram ensolarados, foram 3 e 11 de dezembro onde o tempo permaneceu nublado porém abafado.

A Tabela 30 mostra os pontos de amostra bem como a seqüência em que foram analisados, tanto os pontos internos (escritórios) como externos. 
Tabela 30- Identificação dos pontos de amostras por datas de coleta e análise

\begin{tabular}{|c|c|c|c|}
\hline $\mathbf{N}^{\mathbf{o}}$ & IDENTIFICAÇÃO & Amostra & análise \\
\hline 1 & $\begin{array}{l}\text { Ar externo do escritório da Segurança do Trabalho, fundo da } \\
\text { Consolação }\end{array}$ & $18 / 11$ & $20 / 11$ \\
\hline 2 & Escritório da Segurança do Trabalho, Rua Maria Antonia & $18 / 11$ & $20 / 11$ \\
\hline 3 & Ar externo proveniente da Rua Maria Antonia & $18 / 11$ & $20 / 11$ \\
\hline 4 & Setor de Seleção de Pessoal, Rua Maria Antonia & $\overline{18 / 11}$ & $20 / 11$ \\
\hline 5 & Setor de Folha de Pagamento. Rua Maria Antonia & $18 / 11$ & $20 / 11$ \\
\hline 6 & Ar externo do Edifício na Rua da Consolação & $19 / 11$ & $20 / 11$ \\
\hline 7 & Secretaria de Pós Grad. no Edifício da Consolação, $1^{\circ}$ andar & $19 / 11$ & $20 / 11$ \\
\hline 8 & $\begin{array}{l}\text { Coordenação da Pós Graduação, Edificio da Consolação, } 7^{\circ} \\
\text { andar }\end{array}$ & $19 / 11$ & $20 / 11$ \\
\hline 9 & $\begin{array}{l}\text { Diretoria/Presidência, secretaria, Edificio da Consolação, } 10^{\circ} \\
\text { andar }\end{array}$ & $19 / 11$ & $20 / 11$ \\
\hline 10 & $\begin{array}{l}\text { Ar externo do Edifício de uma Faculdade, esquina da Amaral } \\
\text { Gurgel com Maria Borba }\end{array}$ & $27 / 11$ & $28 / 11$ \\
\hline 11 & Ar externo do Edificio á Rua Maria Borba & $27 / 11$ & $28 / 11$ \\
\hline 12 & $\begin{array}{l}\text { Secretaria no térreo do Edificio na esquina da Amaral Gurgel } \\
\text { com Maria Borba }\end{array}$ & $27 / 11$ & $28 / 11$ \\
\hline 13 & Secretaria do Edificio á Rua Maria Borba, $1^{\circ}$ andar. & $27 / 11$ & $28 / 11$ \\
\hline 14 & $\begin{array}{l}\text { Ar externo do Edificio á Rua Maria Borba, captação voltada } \\
\text { para Praça Roosevelt }\end{array}$ & $27 / 11$ & $28 / 11$ \\
\hline 15 & $\begin{array}{l}\text { Escritório do setor de Auditoria, Edifício da Rua Maria Borba, } \\
9^{\circ} \text { andar }\end{array}$ & $27 / 11$ & $28 / 11$ \\
\hline 16 & $\begin{array}{l}\text { Ar externo do Edificio da secretaria de um colégio na esquina } \\
\text { da Rua Piauí com Rua Itambé }\end{array}$ & $27 / 11$ & $28 / 11$ \\
\hline 17 & $\begin{array}{l}\text { Secretaria de um colégio, esquina da Rua Piauí com Rua } \\
\text { Itambé, } 1^{\circ} \text { andar }\end{array}$ & $27 / 11$ & $28 / 11$ \\
\hline 18 & $\begin{array}{l}\text { Ar externo da secretaria de uma Faculdade de Psicologia, } \\
\text { centro do campus, arborizado }\end{array}$ & $27 / 11$ & $28 / 11$ \\
\hline 19 & Secretaria da Faculdade de Psicologia, edifício no centro do & $27 / 11$ & $28 / 11$ \\
\hline
\end{tabular}




\begin{tabular}{|c|c|c|c|}
\hline & can & & \\
\hline 20 & $\begin{array}{l}\text { Escritório do Diretor de um Centro de Radioastronomia dentro } \\
\text { do campus universitário, frente para Rua da Consolação }\end{array}$ & $03 / 12$ & $05 / 12$ \\
\hline 21 & $\begin{array}{l}\text { Ar externo do Edifício do Centro de Radioastronomia dentro } \\
\text { do campus universitário, Rua da Consolação }\end{array}$ & $03 / 12$ & $05 / 12$ \\
\hline 22 & $\begin{array}{l}\text { Escritório dos pesquisadores, Centro de Radioastronomia } \\
\text { dentro do campus universitário, Rua da Consolação }\end{array}$ & $03 / 12$ & $05 / 12$ \\
\hline 23 & $\begin{array}{l}\text { Escritório da Vice Diretora do Centro de Radioastronomia } \\
\text { dentro do campus universitário, Rua da Consolação }\end{array}$ & $03 / 12$ & $05 / 12$ \\
\hline 24 & $\begin{array}{l}\text { Escritório da Vice Diretora do Centro de Radioastronomia } \\
\text { dentro do campus universitário, Rua da Consolação }\end{array}$ & $04 / 12$ & $05 / 12$ \\
\hline 25 & $\begin{array}{l}\text { Ar externo do Edifício Centro de Radioastronomia dentro do } \\
\text { campus universitário, Rua da Consolação }\end{array}$ & $04 / 12$ & $05 / 12$ \\
\hline 26 & Escritório da Segurança do Trabalho, Rua Maria Antonia & $04 / 12$ & $05 / 12$ \\
\hline 27 & $\begin{array}{l}\text { Ar externo do Edifício de uma Faculdade, esquina da Amaral } \\
\text { Gurgel com Maria Borba }\end{array}$ & $04 / 12$ & $05 / 12$ \\
\hline 28 & $\begin{array}{l}\text { Secretaria no térreo do Edificio na esquina da Amaral Gurgel } \\
\text { com Maria Borba }\end{array}$ & $04 / 12$ & $05 / 12$ \\
\hline 29 & $\begin{array}{l}\text { Ar externo do Edifício da Segurança do Trabalho, fundo da } \\
\text { Consolação }\end{array}$ & $04 / 12$ & $05 / 12$ \\
\hline 30 & $\begin{array}{l}\text { Ar externo do Edificio Centro de Radioastronomia dentro do } \\
\text { campus universitário, Rua da Consolação }\end{array}$ & $10 / 12$ & $12 / 12$ \\
\hline 31 & $\begin{array}{l}\text { Escritório da Vice Diretora do Centro de Radioastronomia } \\
\text { dentro do campus universitário, Rua da Consolação }\end{array}$ & $10 / 12$ & $12 / 12$ \\
\hline 32 & $\begin{array}{l}\text { Ar externo do Edificio da Rua Maria Borba, captação voltada } \\
\text { para Praça Roosevelt }\end{array}$ & $10 / 12$ & $12 / 12$ \\
\hline 33 & $\begin{array}{l}\text { Escritório do setor de Auditoria, Edifício da Rua Maria Borba, } \\
9^{\circ} \text { andar }\end{array}$ & $10 / 12$ & $12 / 12$ \\
\hline 34 & Ar externo do Edifício á Rua Maria Borba & $10 / 12$ & $12 / 12$ \\
\hline 35 & Secretaria do Edifício á Rua Maria Borba, $1^{\circ}$ andar. & $10 / 12$ & $12 / 12$ \\
\hline 36 & Ar externo do Edifício de um colégio na esquina da Rua Piauí & $11 / 12$ & $12 / 12$ \\
\hline
\end{tabular}




\begin{tabular}{|c|c|c|c|}
\hline & com Rua Itambé & & \\
\hline 37 & $\begin{array}{l}\text { Secretaria de um colégio na esquina da Rua Piauí com Rua } \\
\text { Itambé, } 1^{\circ} \text { andar }\end{array}$ & $11 / 12$ & $12 / 12$ \\
\hline 38 & $\begin{array}{l}\text { Ar de captação da secretaria da Faculdade de Psicologia, } \\
\text { centro do campus, arborizado }\end{array}$ & $11 / 12$ & $12 / 12$ \\
\hline 39 & Secretaria de uma Faculdade de Psicologia, centro do campus & $11 / 12$ & $12 / 12$ \\
\hline 40 & $\begin{array}{l}\text { Ar externo do Edificio da Rua Maria Borba, captação voltada } \\
\text { para Praça Roosevelt }\end{array}$ & $11 / 12$ & $12 / 12$ \\
\hline 41 & $\begin{array}{l}\text { Escritório do setor de Auditoria, Edificio da Rua Maria Borba, } \\
9^{\circ} \text { andar }\end{array}$ & $11 / 12$ & $12 / 12$ \\
\hline 42 & $\begin{array}{l}\text { Ar externo do Edificio de uma Faculdade, esquina da Amaral } \\
\text { Gurgel com Maria Borba }\end{array}$ & $11 / 12$ & $12 / 12$ \\
\hline 43 & $\begin{array}{l}\text { Secretaria no térreo do Edificio na esquina da Amaral Gurgel } \\
\text { com Maria Borba }\end{array}$ & $11 / 12$ & $12 / 12$ \\
\hline 44 & Ar externo do Edificio á Rua Maria Borba & $11 / 12$ & $12 / 12$ \\
\hline 45 & Secretaria do Edifício á Rua Maria Borba, $1^{\circ}$ andar. & $11 / 12$ & $12 / 12$ \\
\hline 46 & $\begin{array}{l}\text { Ar de captação da secretaria da Faculdade de Psicologia, } \\
\text { centro do campus, arborizado }\end{array}$ & $18 / 12$ & $19 / 12$ \\
\hline 47 & $\begin{array}{l}\text { Secretaria da Faculdade de Psicologia, centro do campus, } \\
\text { Edificio } 16\end{array}$ & $18 / 12$ & $19 / 12$ \\
\hline 48 & $\begin{array}{l}\text { Ar externo do Edifício de um colégio na esquina da Rua Piauí } \\
\text { com Rua Itambé }\end{array}$ & $18 / 12$ & $19 / 12$ \\
\hline 49 & $\begin{array}{l}\text { Secretaria de um colégio na esquina da Rua Piauí com Rua } \\
\text { Itambé, } 1^{\circ} \text { andar }\end{array}$ & $18 / 12$ & $19 / 12$ \\
\hline 50 & Ar externo proveniente da Rua Maria Antonia & $18 / 12$ & $19 / 12$ \\
\hline 51 & Setor de Folha de Pagamento. Rua Maria Antonia & $18 / 12$ & $19 / 12$ \\
\hline 52 & Ar externo do Edificio na Rua da Consolação 896 & $18 / 12$ & $19 / 12$ \\
\hline 53 & $\begin{array}{l}\text { Coordenação da Pós Graduação no Edificio da Rua da } \\
\text { Consolação, } 7^{\circ} \text { andar }\end{array}$ & $18 / 12$ & $19 / 12$ \\
\hline 54 & 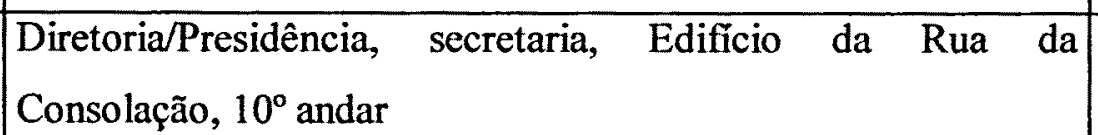 & $18 / 12$ & $19 / 12$ \\
\hline
\end{tabular}




\subsection{1- Resultados Quantitativos}

As análises das amostras ocorreram na seguinte seqüência:

Análise do branco,

Análise da amostra pelo método SIM (monitoramento de íons),

Análise da amostra pelo método SCAN (varredura de íons).

Para o resultado quantitativo foram utilizadas curvas de calibração preparadas no dia da análise tomando por base os padrões citados em 3.2.2.1 .

A Tabela 31 mostra de forma geral os resultados quantitativos obtidos nas análises de todas amostras para Tetracloreto de Carbono, Clorofórmio, Benzeno e Tolueno. 
Tabela 31- Resultados das análises de tetracloreto de carbono $\left(\mathrm{CCl}_{4}\right)$, clorofórmio $\left(\mathrm{HCCl}_{3}\right)$, benzeno e tolueno por amostra

\begin{tabular}{|c|c|c|c|c|}
\hline Amostra & $\mathrm{CCl}_{4}(\mathrm{ppb}$ v) & $\mathrm{HCCl}_{3}(\mathrm{ppb} v)$ & Benzeno (ppb v) & Tolueno (ppb v) \\
\hline 1 & 0,05 & $<0,01$ & 0,16 & 10,61 \\
\hline 2 & 0,04 & $<0,01$ & 1,26 & 11,58 \\
\hline 3 & $<0,01$ & $<0,01$ & 0,31 & 7,32 \\
\hline 4 & $<0,01$ & $<0,01$ & $<0,01$ & 9,66 \\
\hline 5 & $<0,01$ & $<0,01$ & $0, \overline{24}$ & 12,71 \\
\hline 6 & $<0,01$ & $<0,01$ & $<0,01$ & 17,31 \\
\hline 7 & $<0,01$ & $<0,01$ & $<0,01$ & 35,52 \\
\hline 8 & $<0,01$ & $<0,01$ & $<0,01$ & 7,67 \\
\hline 9 & $<0,01$ & $<0,01$ & $<0,01$ & 13,69 \\
\hline 10 & $<0,01$ & $<0,01$ & 0,29 & 6,72 \\
\hline 11 & $<0,01$ & $<0,01$ & 0,47 & 6,67 \\
\hline 12 & 0,20 & $<0,01$ & 3,51 & 48,66 \\
\hline 13 & 0,02 & $<0,01$ & 0,77 & 17,34 \\
\hline 14 & $<0,01$ & $<0,01$ & 3,12 & 8,81 \\
\hline 15 & 0,03 & $<0,01$ & 2,63 & 17,17 \\
\hline 16 & $<0,01$ & $<0,01$ & 2,44 & 7,46 \\
\hline 17 & $<0,01$ & $<0,01$ & 2,39 & 10,61 \\
\hline 18 & 0,07 & $<0,01$ & 3,54 & 17,82 \\
\hline 19 & $<0,01$ & $<0,01$ & 2,07 & 31,61 \\
\hline 20 & $<0,01$ & $<0,01$ & 1,88 & 5,82 \\
\hline 21 & 0,03 & $<0,01$ & 4,10 & 19,65 \\
\hline 22 & $<0,01$ & $<0,01$ & 0,03 & 6,03 \\
\hline 23 & $<0,01$ & $<0,01$ & 2,00 & 8,54 \\
\hline 24 & 0,02 & $<0,01$ & 1,95 & 7,69 \\
\hline 25 & $<0,01$ & $<0,01$ & 2,26 & 13,16 \\
\hline 26 & 0,02 & $<0,01$ & 2,35 & 16,87 \\
\hline 27 & $<0,01$ & $<0,01$ & 1,48 & 9,56 \\
\hline 28 & $<0,01$ & $<0,01$ & 1,93 & 22,13 \\
\hline 29 & $<0,01$ & $<0,01$ & 1,94 & 12,01 \\
\hline 30 & 0,02 & $<0,01$ & 2,22 & 18,06 \\
\hline 31 & $<0,01$ & $<0,01$ & 0,14 & 7,74 \\
\hline 32 & $<0,01$ & $<0,01$ & 1,42 & 15,03 \\
\hline 33 & $<0,01$ & $<0,01$ & $<0,01$ & 8,63 \\
\hline 34 & $<0,01$ & $<0,01$ & 0,60 & 9,92 \\
\hline 35 & 0,02 & $<0,01$ & 0,84 & 26,28 \\
\hline 36 & $<0,01$ & $<0,01$ & 0,19 & 4,90 \\
\hline 37 & 0,08 & $<0,01$ & 1,33 & 11,31 \\
\hline 38 & 0,06 & $<0,01$ & 1,53 & 10,90 \\
\hline
\end{tabular}




\begin{tabular}{c|c|c|c|c}
\hline 39 & 0,03 & $<0,01$ & 0,83 & 16,08 \\
\hline 40 & 0,10 & $<0,01$ & 3,65 & 30,44 \\
\hline 41 & 0,05 & $<0,01$ & 2,56 & 10,94 \\
\hline 42 & $<0,01$ & $<0,01$ & 1,07 & 12,35 \\
\hline 43 & $<0,01$ & $<0,01$ & 1,41 & 16,86 \\
\hline 44 & $<0,01$ & $<0,01$ & 0,58 & 12,53 \\
\hline 45 & $<0,01$ & $<0,01$ & 1,74 & 14,79 \\
\hline 46 & 0,01 & $<0,01$ & 1,60 & 16,64 \\
\hline 47 & 0,04 & $<0,01$ & 1,78 & 26,52 \\
\hline 48 & $<0,01$ & $<0,01$ & $<0,01$ & 7,38 \\
\hline 49 & $<0,01$ & $<0,01$ & 1,26 & 7,85 \\
\hline 50 & $<0,01$ & $<0,01$ & 0,25 & 7,65 \\
\hline 51 & 0,04 & $<0,01$ & 0,37 & 12,14 \\
\hline 52 & $<0,01$ & $<0,01$ & $<0,01$ & 18,76 \\
\hline 53 & $<0,01$ & $<0,01$ & $<0,01$ & 7,88 \\
\hline 54 & $<0,01$ & $<0,01$ & $<0,01$ & 14,89 \\
\hline
\end{tabular}

Os resultados obtidos para Tetracloreto de carbono, clorofórmio, benzeno e tolueno não diferiram dos apresentados nas referências Cheng (2000), Perry (1997), Fantuzzi e col. (1996) e Zabiegala e col. (1999) as quais apresentam análises em ambientes fechados com e sem condicionadores de ar. Em todas estas referências foi citado o problema dos contaminantes do ar externo como principais contaminantes do ar interno.Nos resultados obtidos percebemos que o fator ventilação e renovação de ar foi marcante quanto a concentração de poluentes no ar interno, Brickus e Aquino Neto (1999) já alertavam para este problema como sendo uma constante nos escritórios e casas comerciais no Brasil. A concentração de poluentes também pode ser atribuída neste estudo ao fato de que todos os escritórios amostrados sem exceção ficavam fechados totalmente após o expediente, ou seja não havia troca de ar no período noturno até o início do expediente no dia seguinte. Também segundo relatos dos trabalhadores destes escritórios, todos sem exceção ao chegar ao local de trabalho ligavam o condicionador de ar no caso SPLIT ou de janela sem antes arejar o ambiente fazendo com que as substâncias que estavam paradas no ar ficassem em circulação sem diluição.

No caso dos edificios com ar condicionado central, estes quando chegavam para o trabalho o sistema já estava funcionando, ou seja o ar já circulava e os 
trabalhadores não sentiam diferença entre $o$ ar do início do expediente em comparação com o final.

Os resultados quantitativos denotaram uma tendência, pelo menos nos edifícios amostrados, de concentração de poluentes onde os condicionadores eram do tipo SPLIT ou janela e o inverso no caso de condicionadores de ar chamados centrais.

Porém, percebemos que estas informações estão intimamente ligadas à circulação de ar dentro do escritório e também a manutenção dos condicionadores de ar. Isto ficou evidente quando das comparações entre resultados do ar interno com o ar externo e as condições de ventilação e manutenção de cada sistema. 
Da Figura 5 até Figura 28 são mostradas as comparações entre as amostras dos escritórios e suas respectivas amostras de ar externo.

\section{Coleta de 18/11/2002}

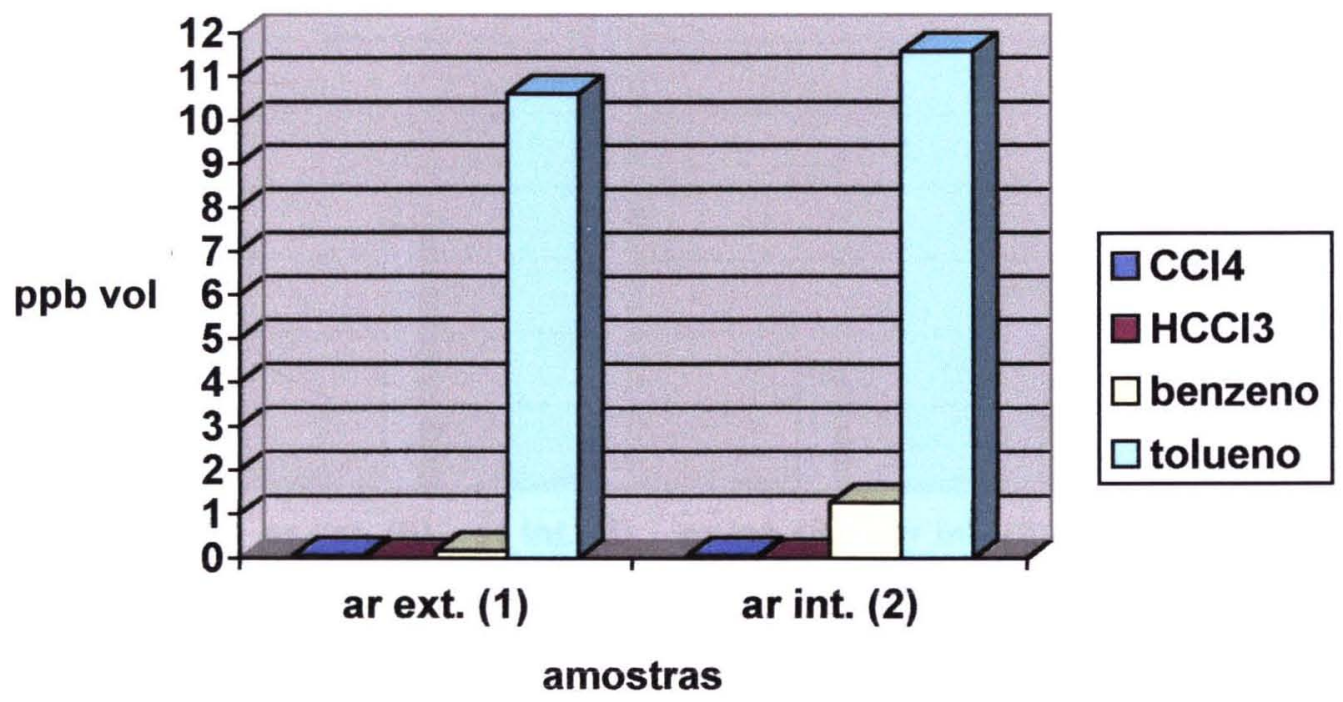

Figura 5- Comparação entre as amostras 1 (ar externo) e 2 (ar interno)

\section{Coleta de 18/11/2002}

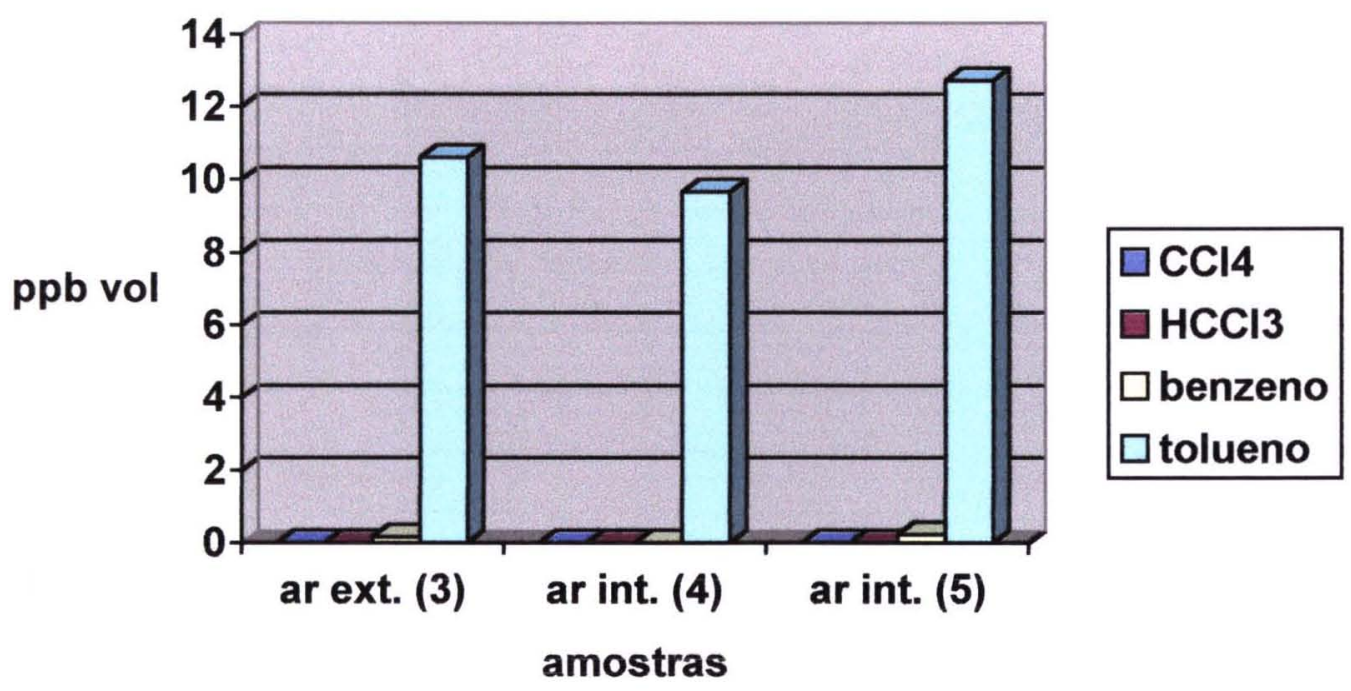

Figura 6- Comparação entre as amostras 3 (ar externo), 4 (ar interno) e 5 (ar interno) 
Coleta de 19/11/2002

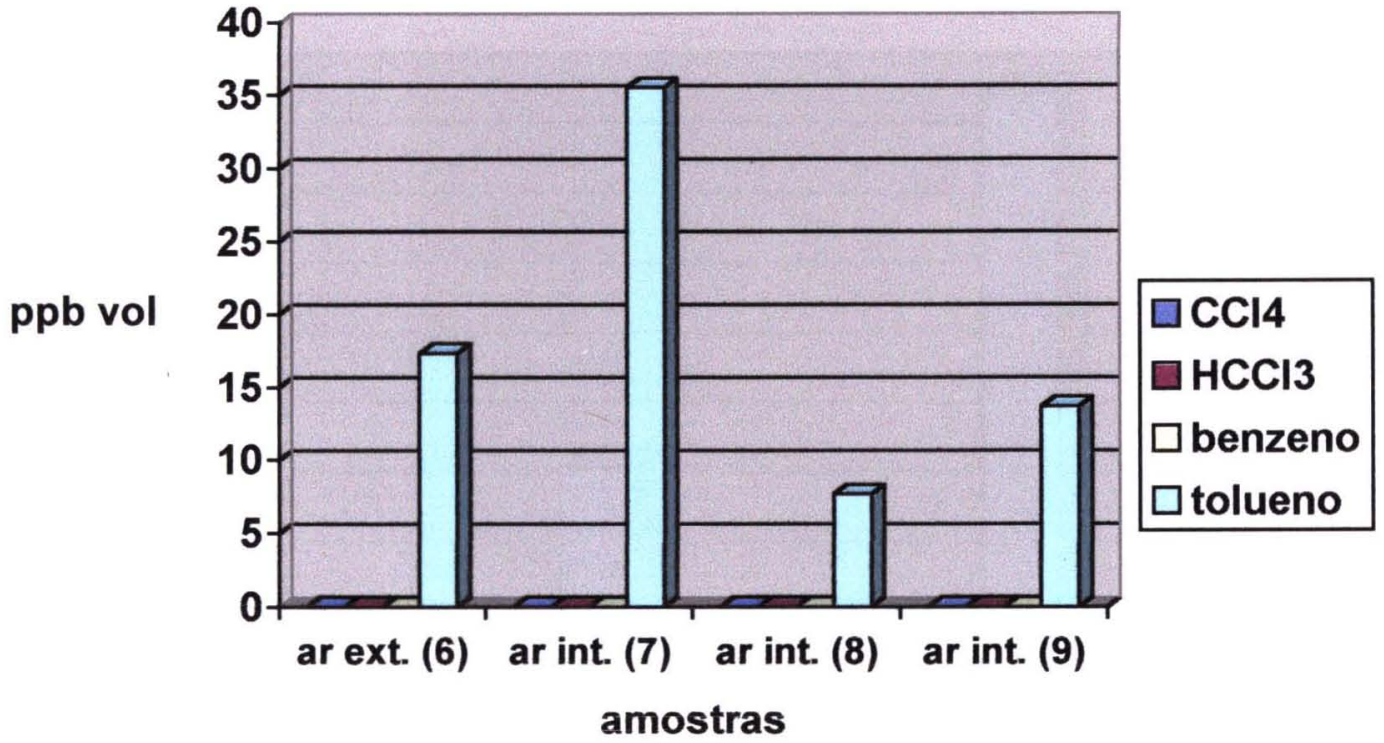

Figura 7- Comparação entre as amostras 6 (ar externo), 7 (ar interno), 8 (ar interno) e 9 (ar interno)

Coleta de 27/11/2002

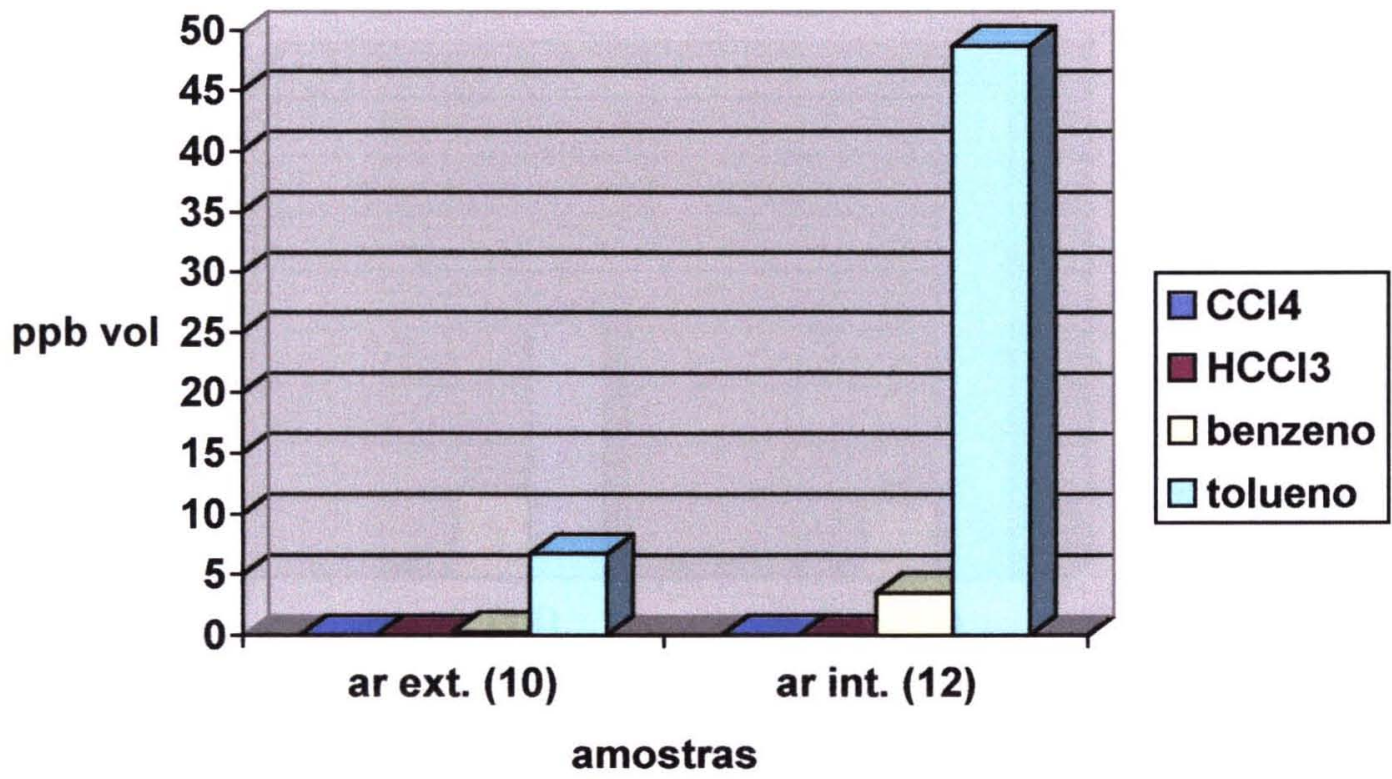

Figura 8- Comparação entre as amostras 10 (ar externo) e 12 (ar interno) 
Coleta de 27/11/2002

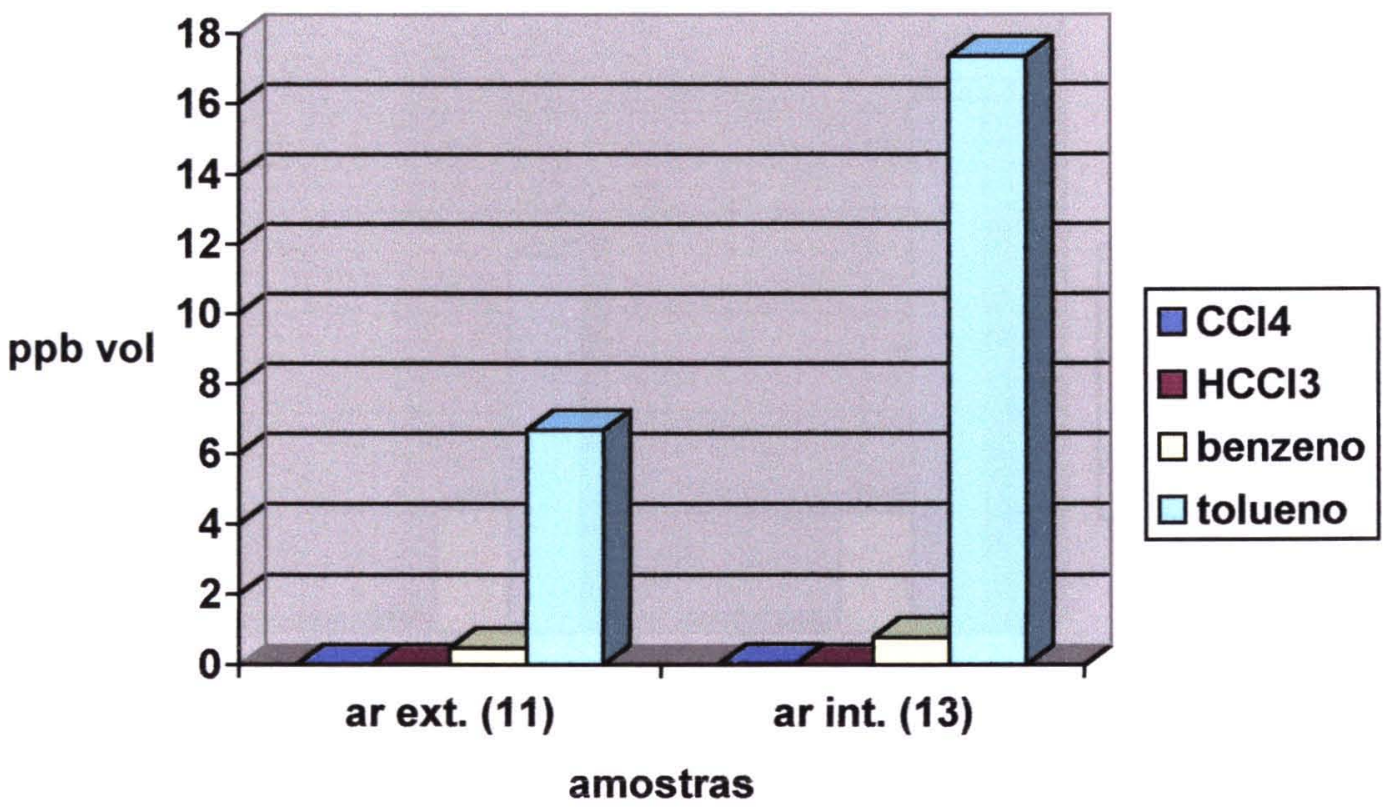

Figura 9- Comparação entre as amostras 11 (ar externo) e 13 (ar interno)

Coleta de 27/11/2002

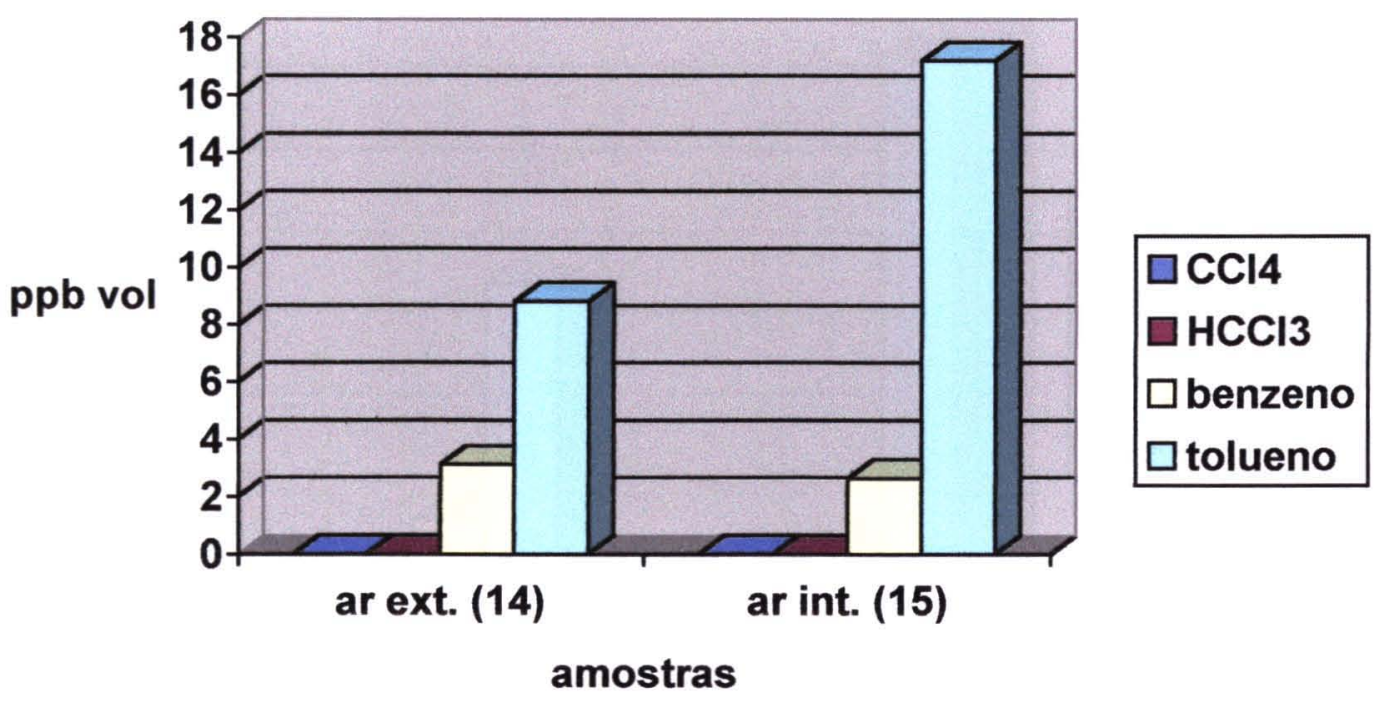

Figura 10- Comparação entre as amostras 14 (ar externo) e 15 (ar interno) 
Coleta de 27/11/2002

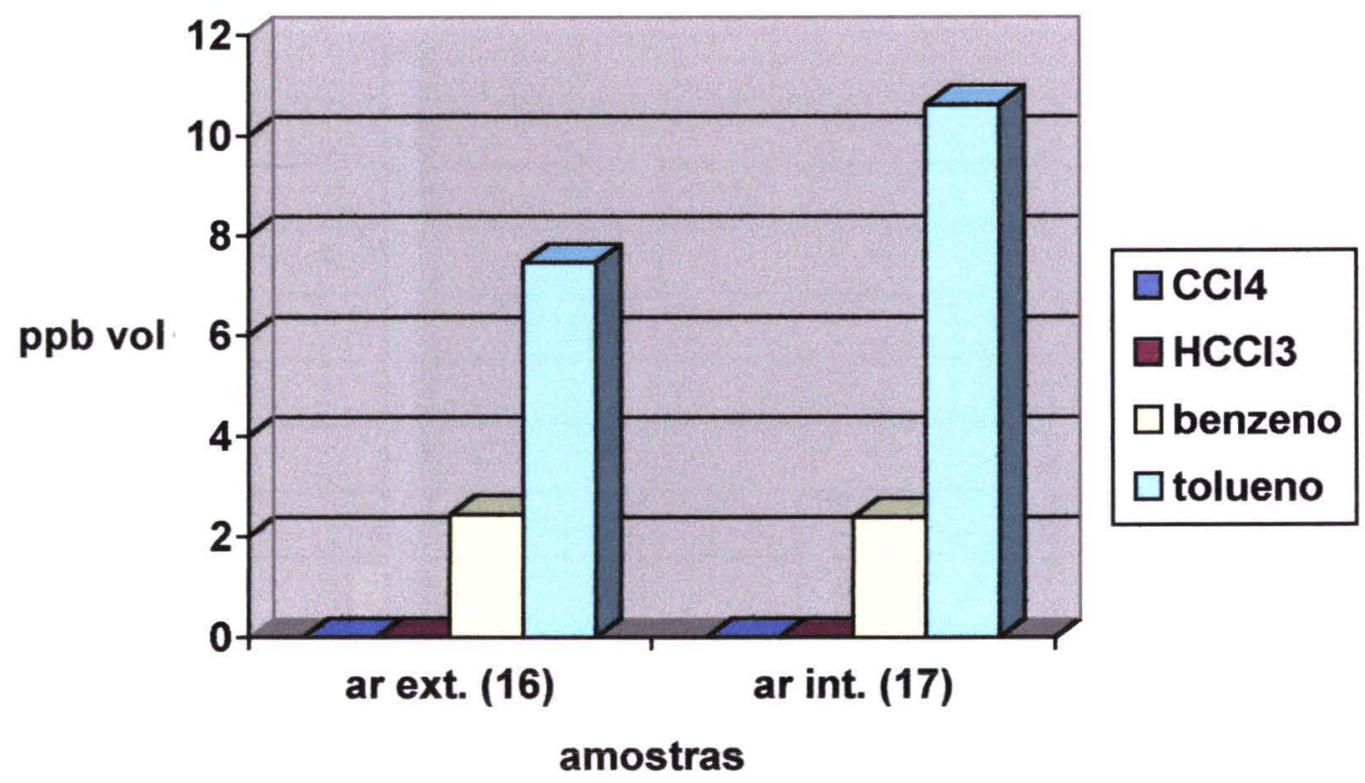

Figura 11- Comparação entre as amostras 16 (ar externo) e 17 (ar interno)

Coleta de 27/11/2002

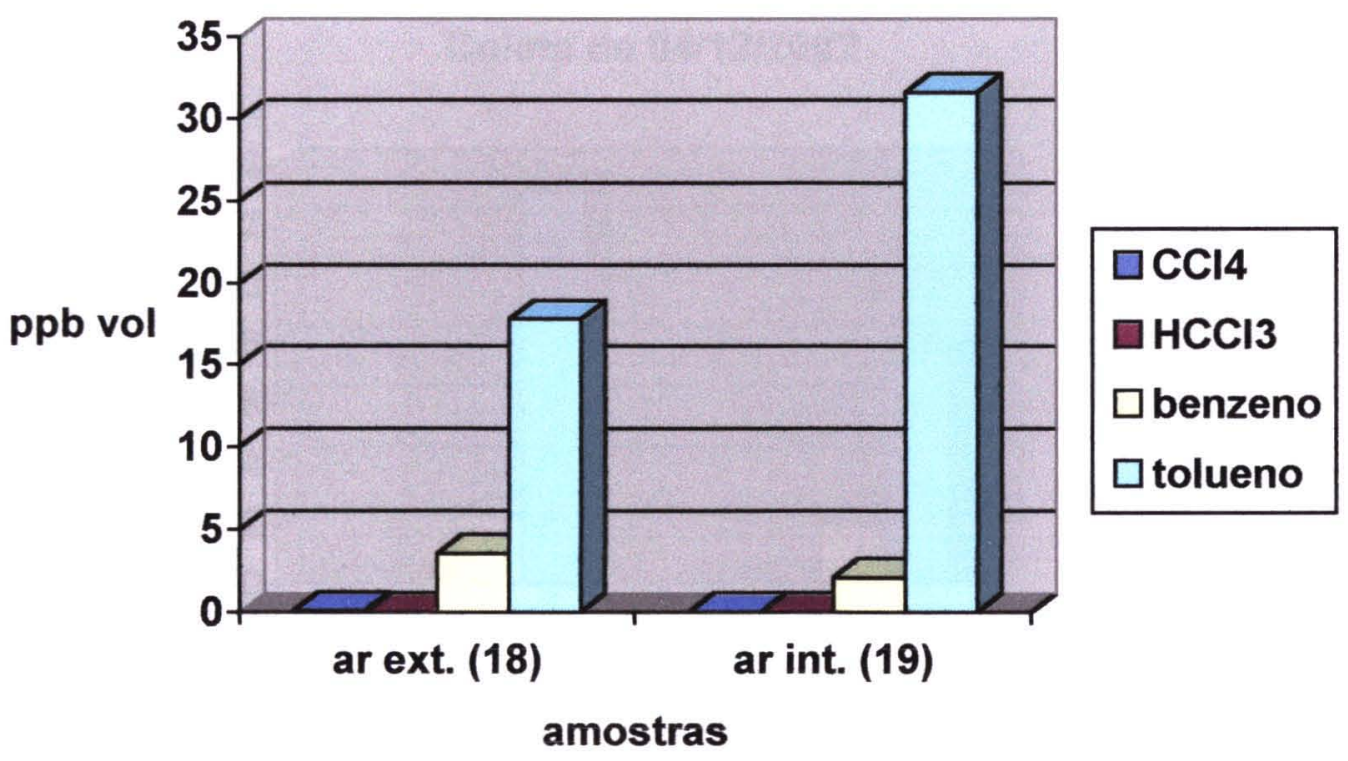

Figura 12- Comparação entre as amostras 18 (ar externo) e 19 (ar interno) 
Coleta de 03/12/2002

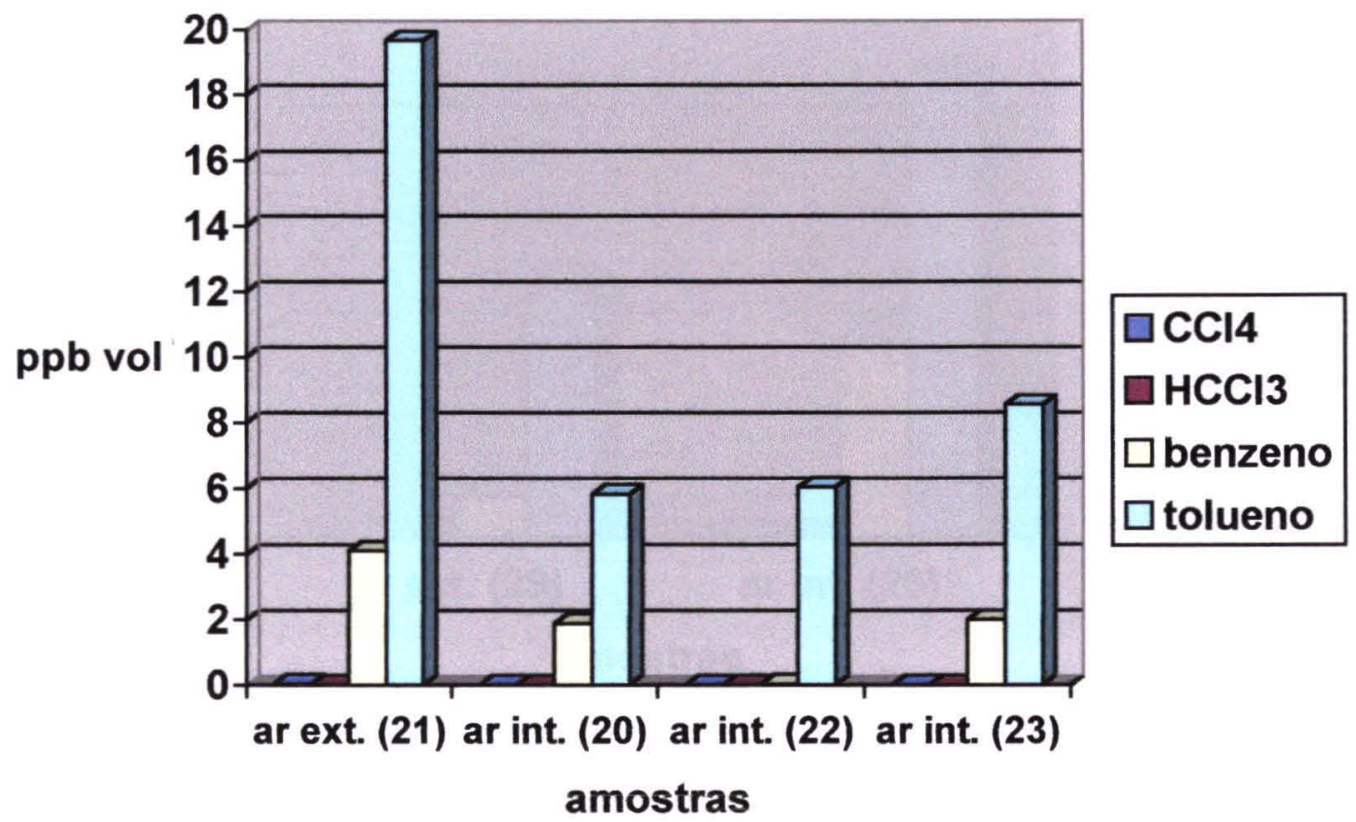

Figura 13- Comparação entre as amostras 21 (ar externo), 20 (ar interno), 22 (ar interno) e 23 (ar interno)

Coleta de 04/12/2002

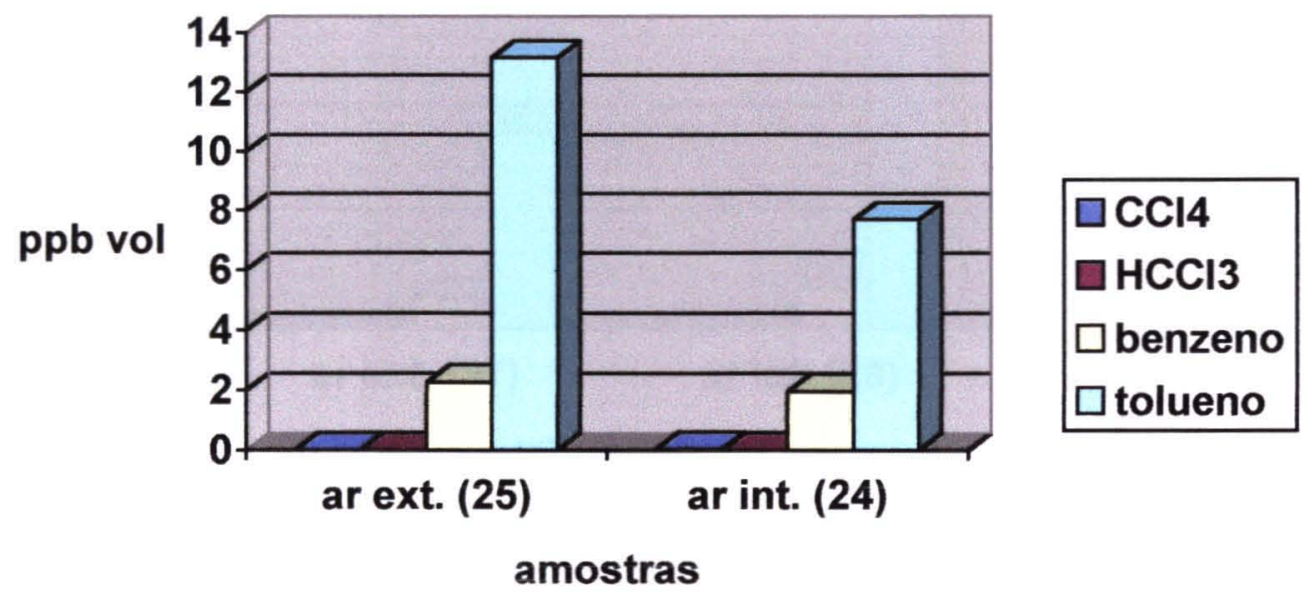

Figura 14- Comparação entre as amostras 25 (ar externo) e 24 (ar interno) 
Coleta de 04/12/2002

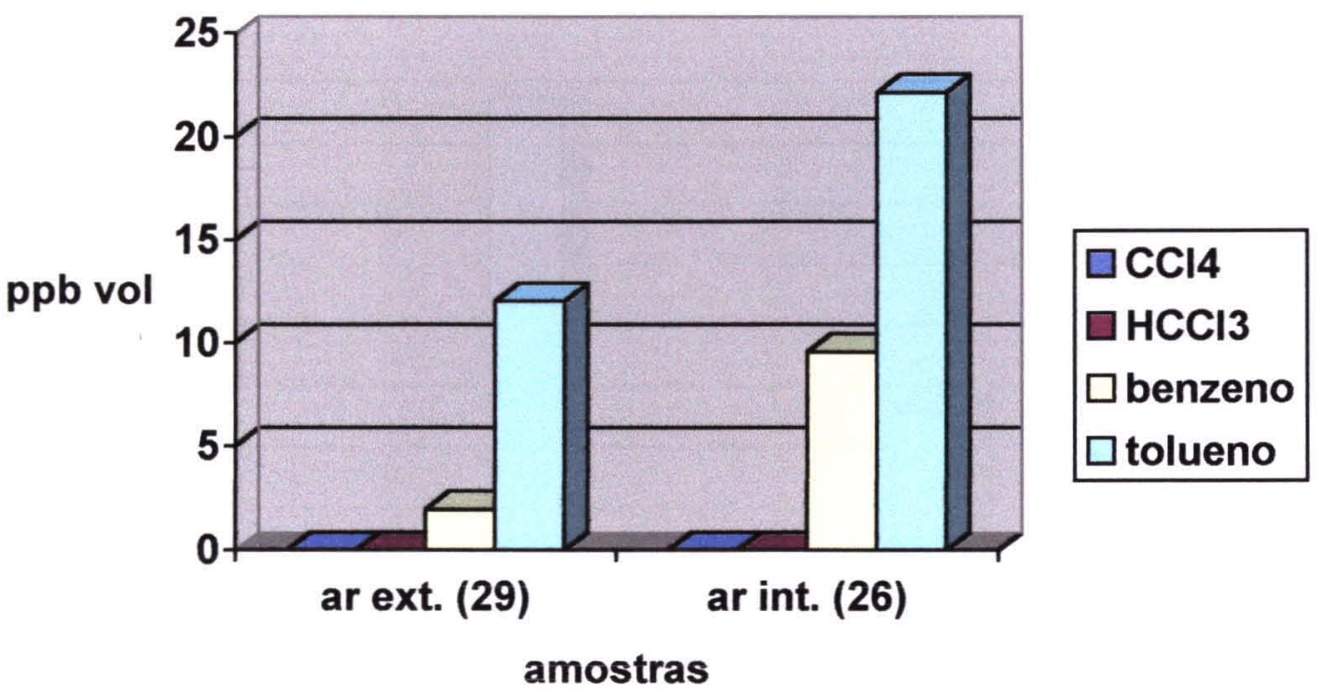

Figura 15- Comparação entre as amostras 29 (ar externo) e 26 (ar interno)

\section{Coleta de 04/12/2002}

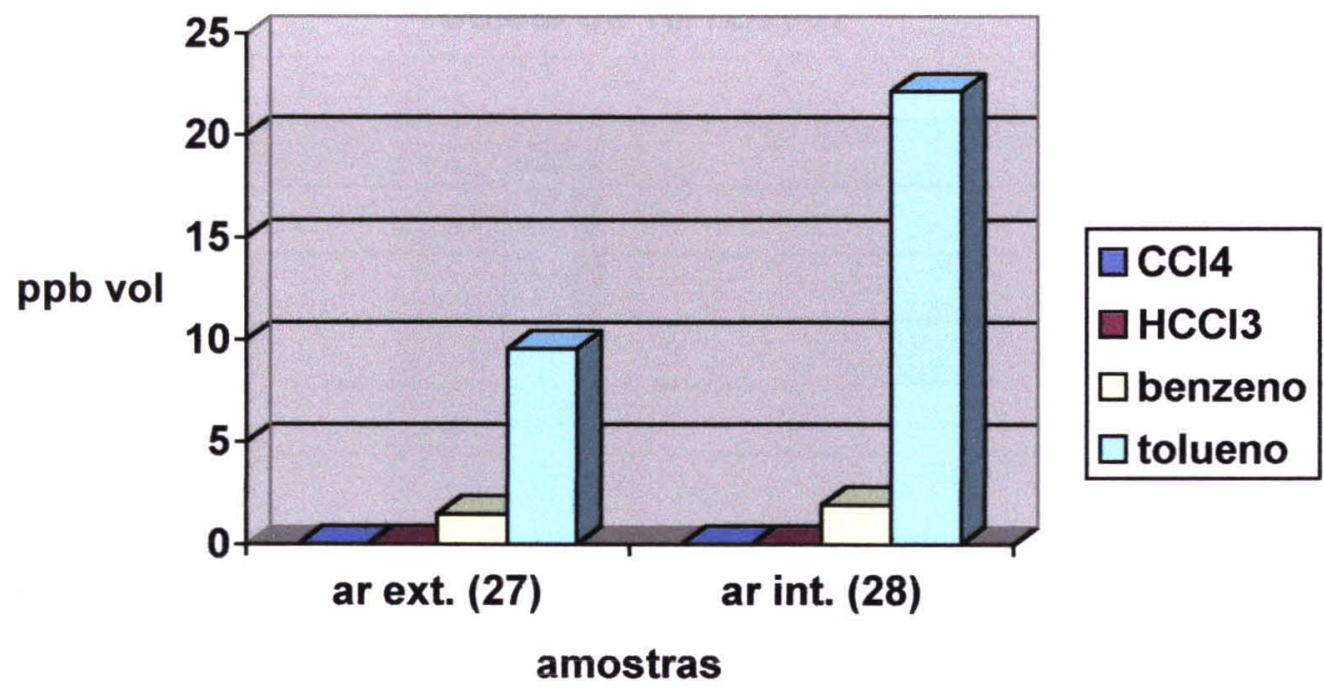

Figura 16- Comparação entre as amostras 27 (ar externo) e 28 (ar interno) 
Coleta de 10/12/2002

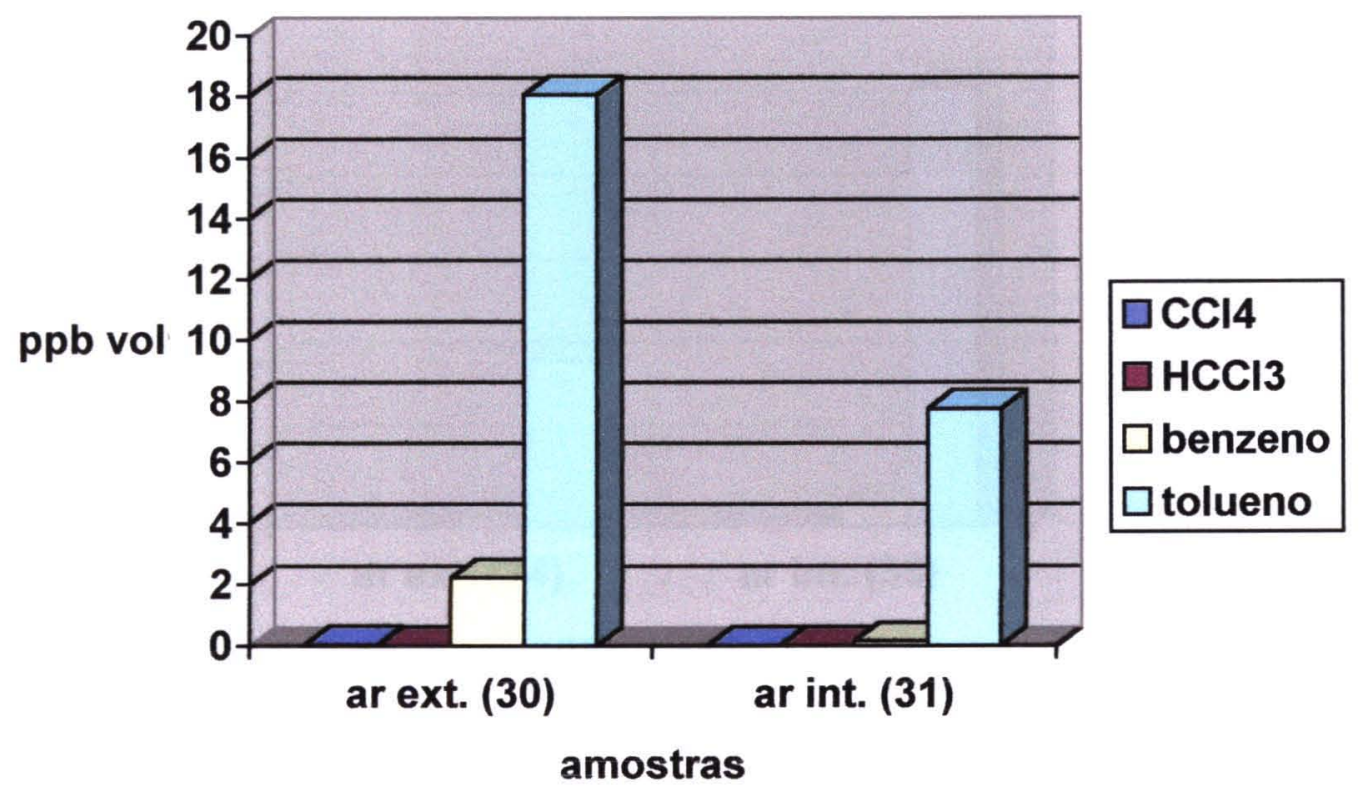

Figura 17- Comparação entre as amostras 30 (ar externo) e 31 (ar interno)

Coleta de 10/12/2002

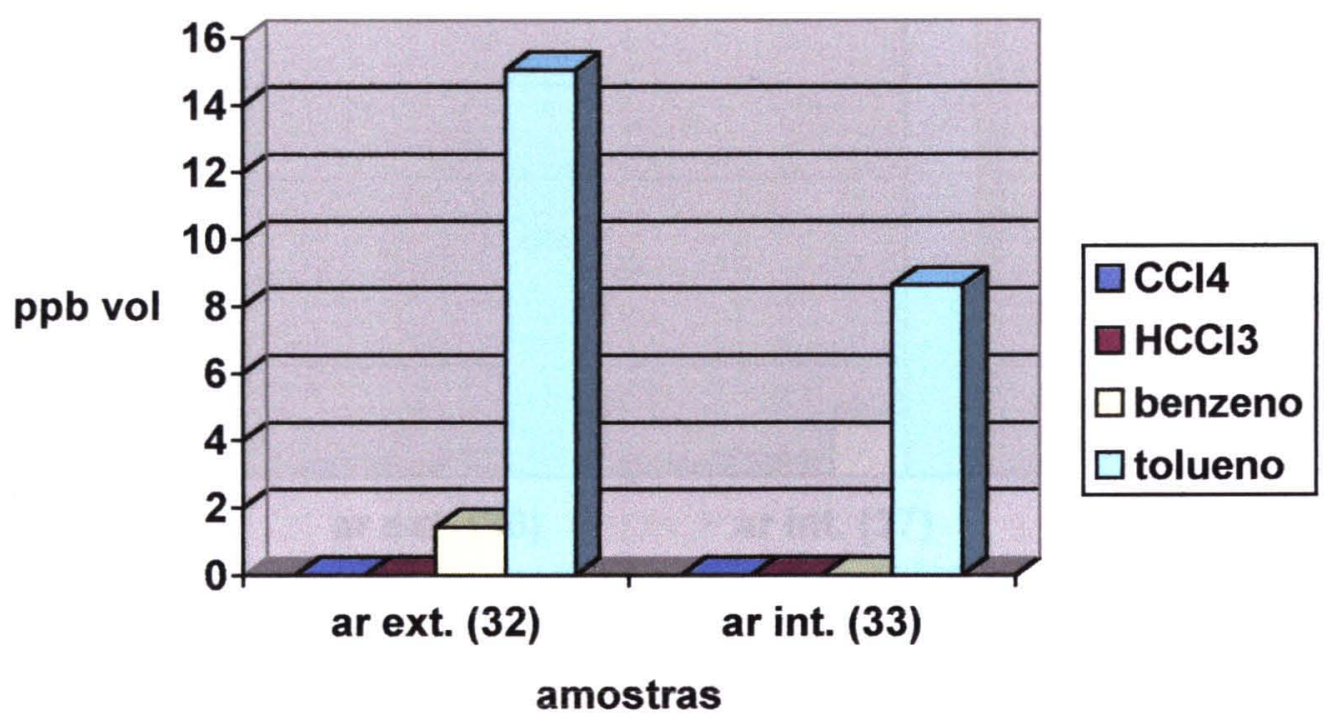

Figura 18- Comparação entre as amostras 32 (ar externo) e 33(ar interno) 
Coleta de 10/12/2002

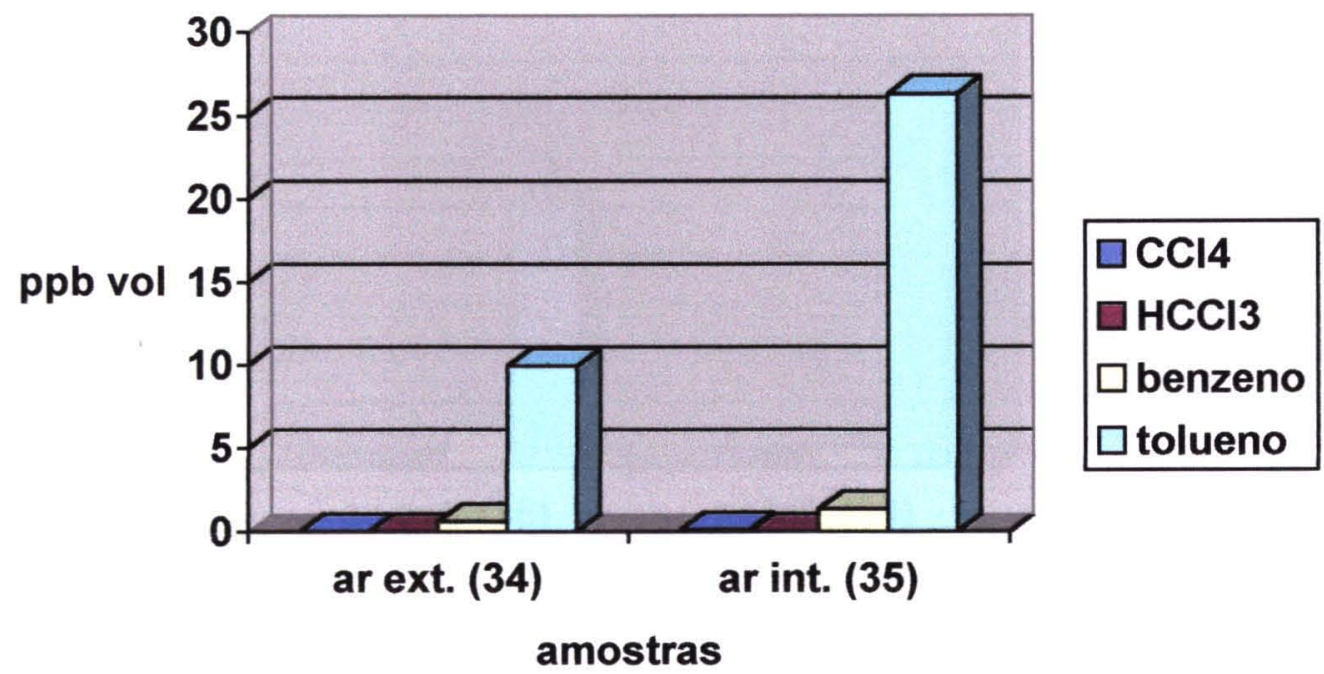

Figura 19- Comparação entre as amostras 34 (ar externo) e 35 (ar interno)

\section{Coleta de 11/12/2002}

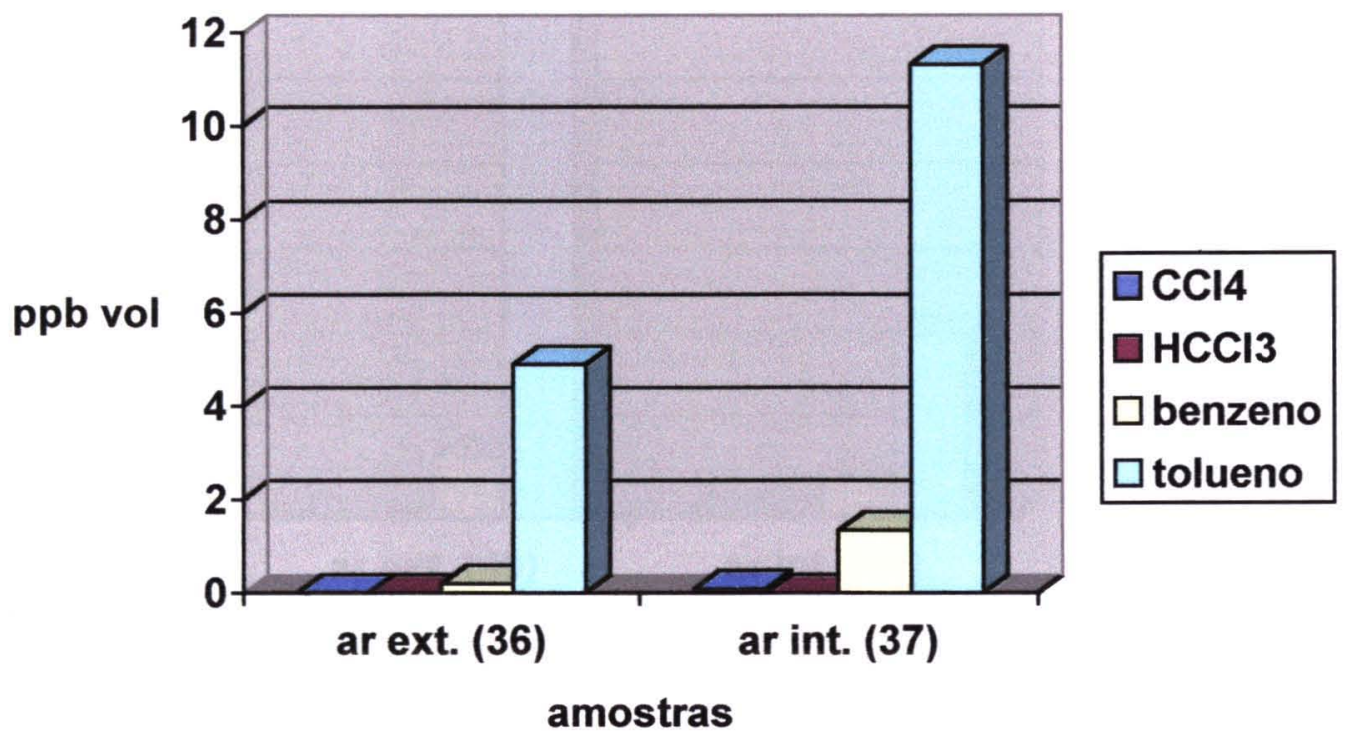

Figura 20- Comparação enter as amostras 36 (ar externo) e 37 (ar interno) 


\section{Coleta de 11/12/2002}

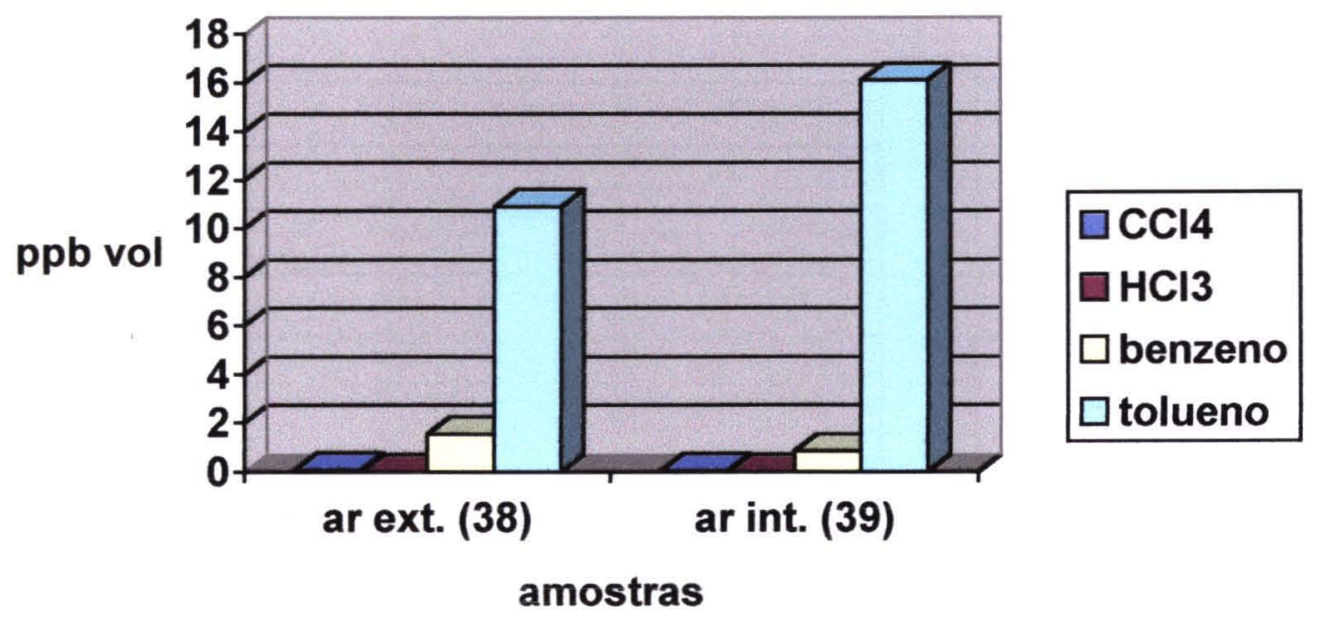

Figura 21- Comparação enter as amostras 38 (ar externo) e 39 (ar interno)

\section{Coleta de 11/12/2002}

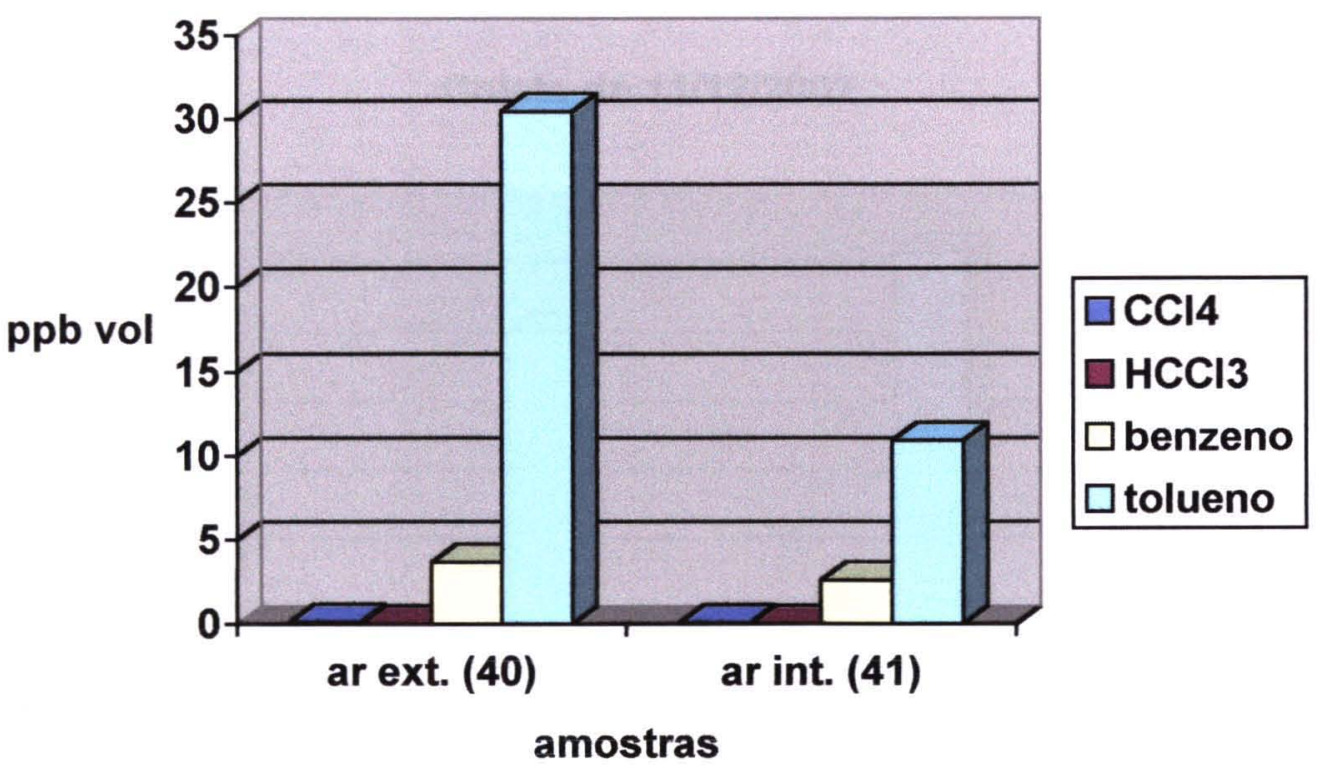

Figura 22- comparação entre as amostras 40 (ar externo) e 41 (ar interno) 
Coleta de 11/12/2002

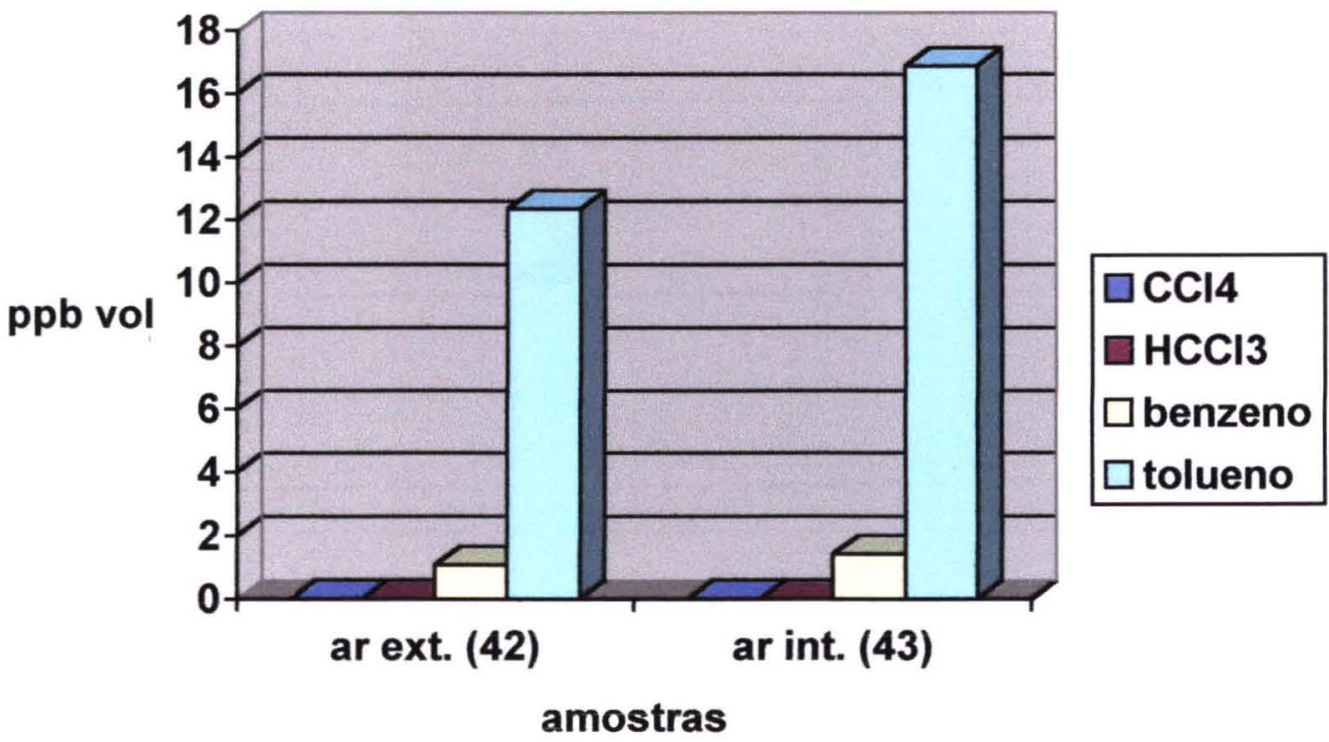

Figura 23- Comparação entre as amostras 42 (ar externo) e 43 (ar interno)

Coleta de 11/12/2002

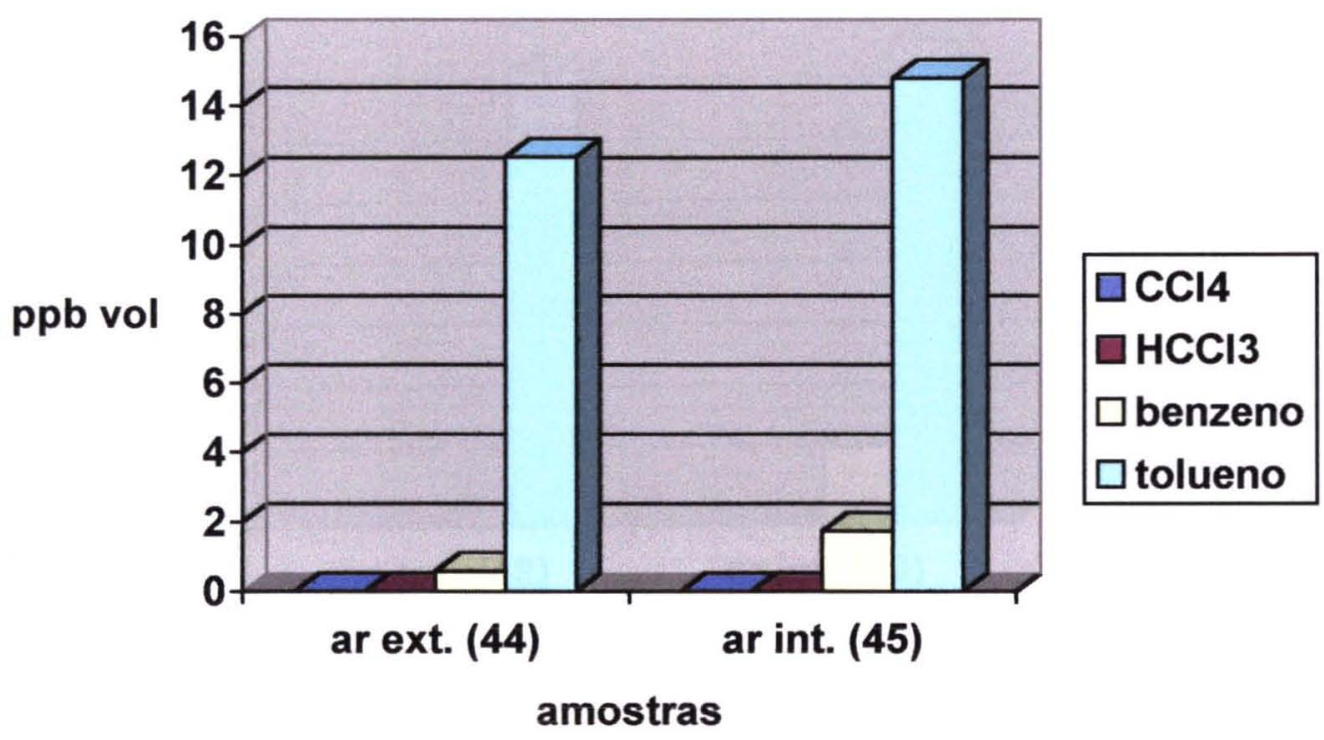

Figura 24- Comparação entre as amostras 44 (ar externo) e 45 (ar interno) 
Coleta de 18/12/2002

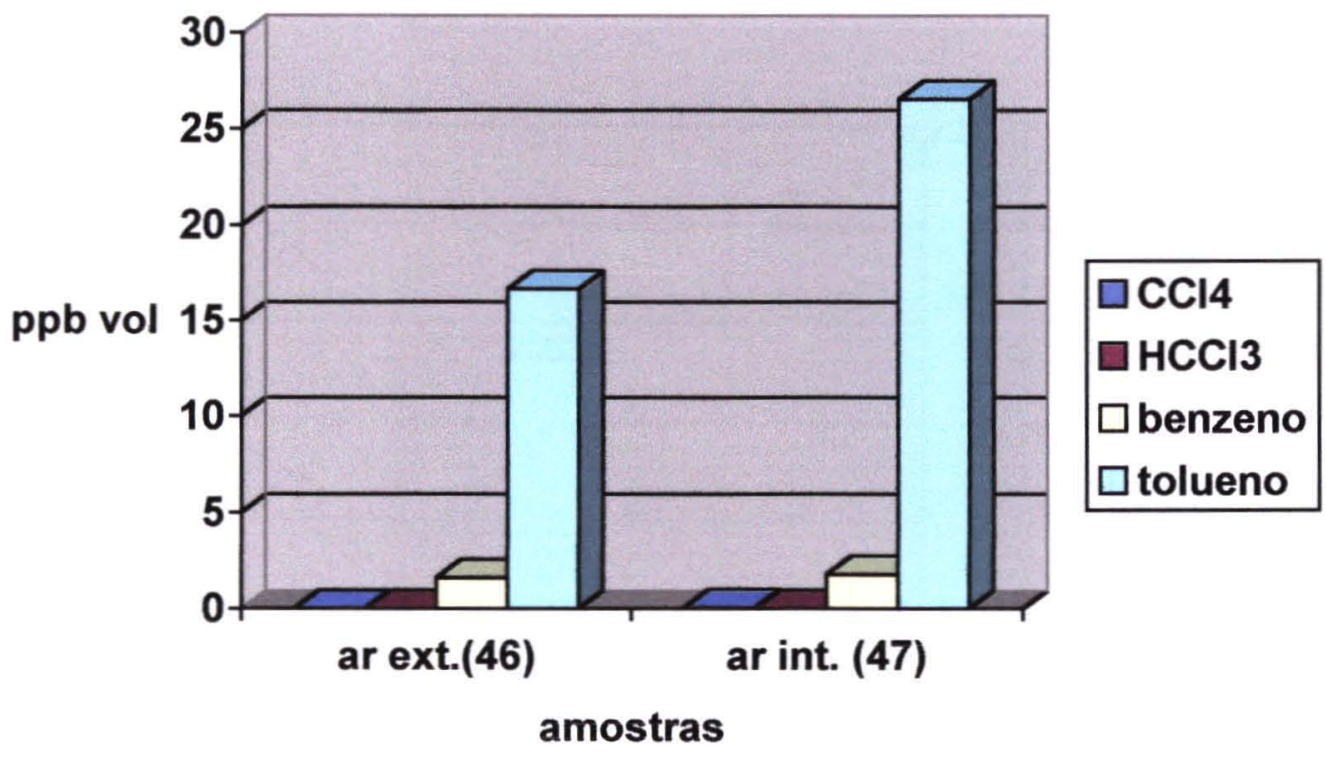

Figura 25- Comparação entre as amostras 46 (ar externo) e 47 (ar interno)

\section{Coleta de 18/12/2002}

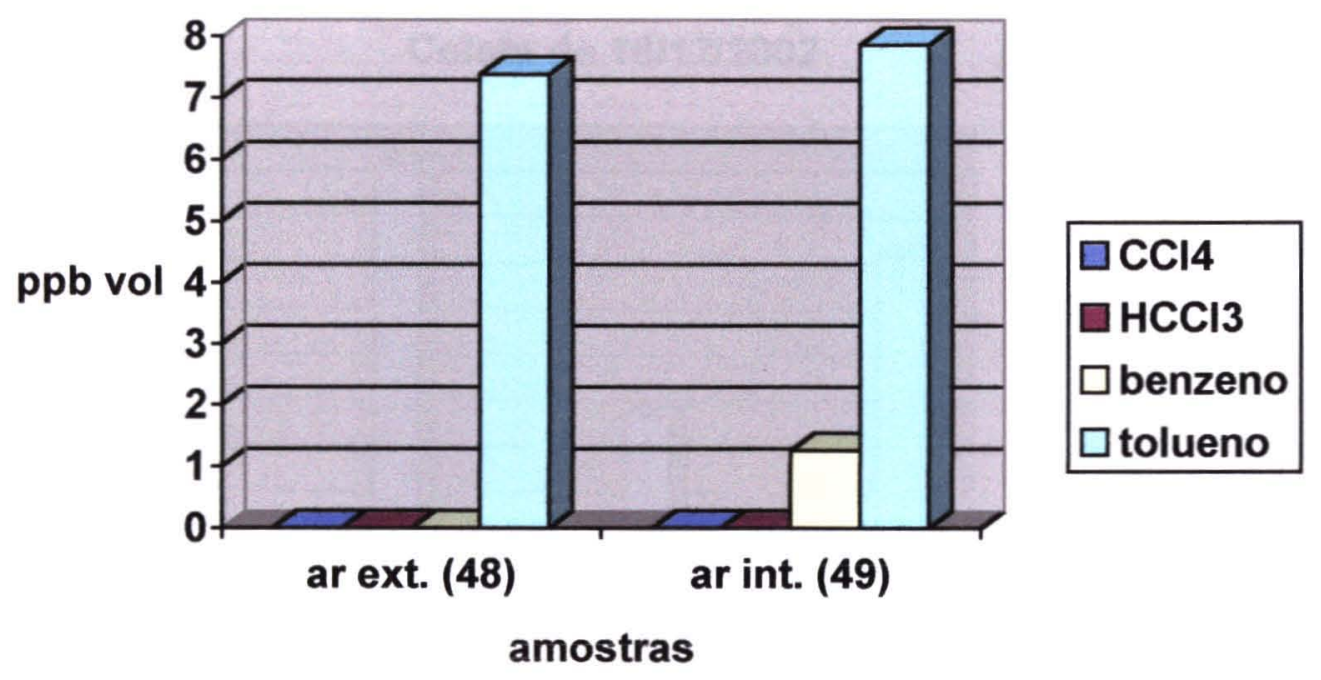

Figura 26- Comparação entre as amostras 48 (ar externo) e 49 (ar interno) 
Coleta de 18/12/2002

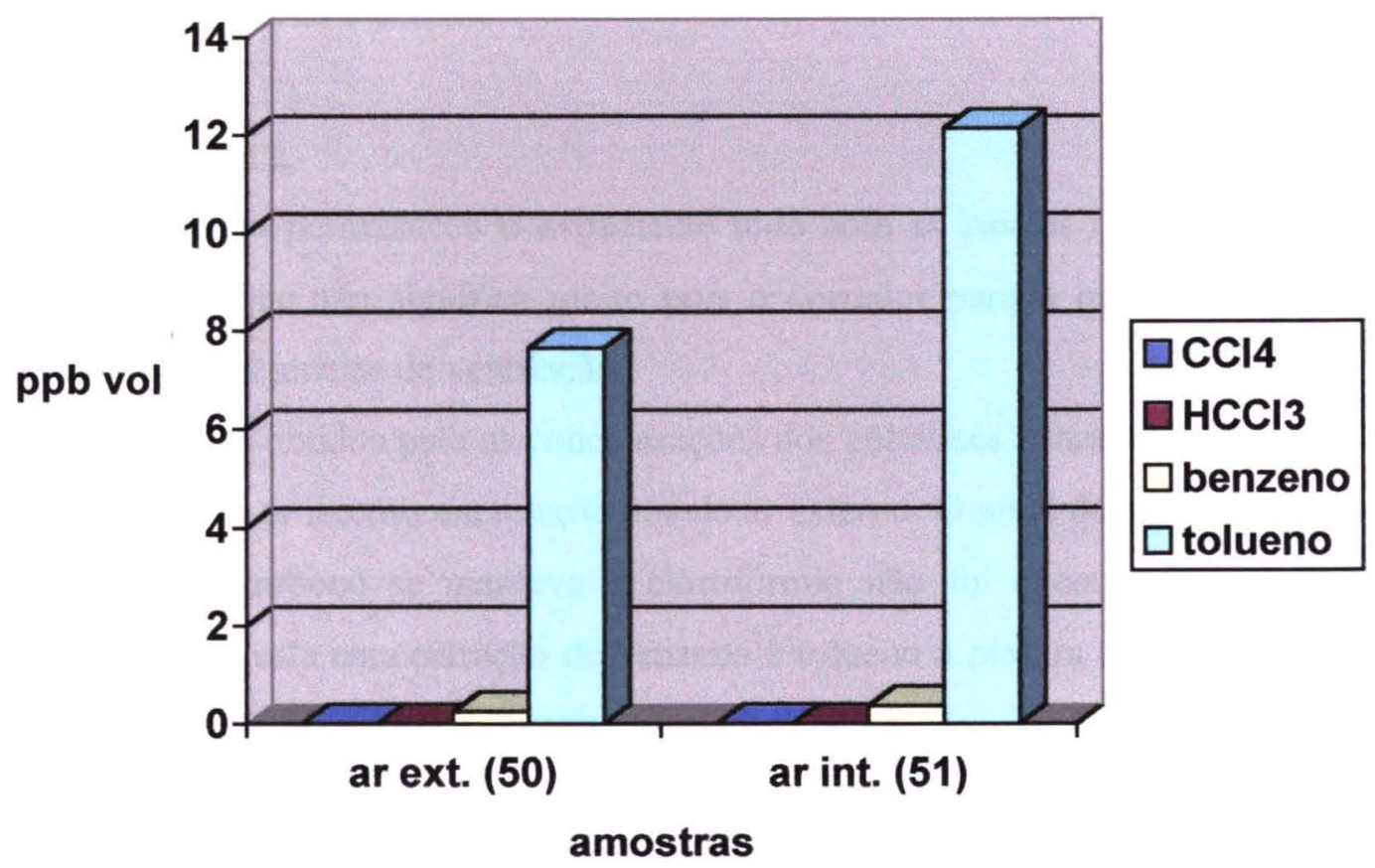

Figura 27- Comparação entre as amostras 50 (ar externo) e 51 (ar interno)

Coleta de 18/12/2002

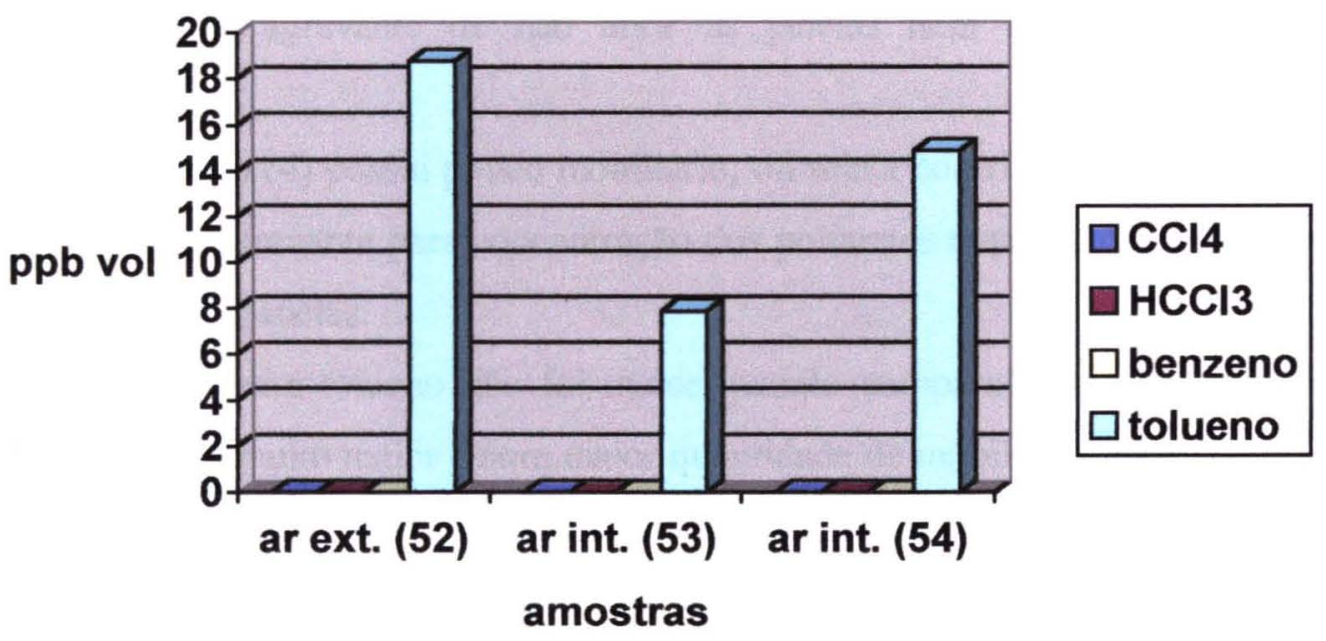

Figura 28- Comparação entre as amostras 52 (ar externo), 53 (ar interno) e 54 (ar interno) 


\subsubsection{1- Discussão dos resultados quantitativos}

Seguem os comentários e observações de cada comparação realizada entre as amostras de ar interno e externo.

\section{Amostras 1 e 2}

Este escritório permaneceu o expediente todo com as janelas fechadas e com a porta aberta, o que não significa muito pois o corredor para o qual esta porta dá acesso não possui janelas de ventilação.

Os resultados obtidos para as concentrações dos poluentes benzeno e tolueno são mais elevados no ar interno em relação aos do ar externo. $O$ nivel de concentração de tetracloreto de carbono se manteve e clorofórmio não foi encontrado.Podem ter contribuído para esta concentração de benzeno e tolueno a pintura da parede e porta que eram recentes, com menos de seis meses.

Um ponto importante para concentração destas substâncias é que o escritório após o expediente fica fechado e quando se inicia o trabalho a janela fica aberta por pouco tempo, em torno de uma hora.

\section{Amostras 3, 4 e 5}

A amostra 4 se refere a um escritório que também fica com janelas fechadas, porém possui o agravante de não abrir as janelas nem mesmo no início do expediente.

Este escritório (4) possui pouco mobiliário, ou seja a contribuição dos materiais é pequena mas o agravante para concentração dos poluentes é que este fica no final de um corredor sem janelas.

O resultado para tolueno não foi maior quando comparado ao do escritório 5 , sendo que este é muito maior e com maior quantidade de mobiliário, papel e pessoas.

O fato de quase dobrar a concentração de benzeno neste escritório, em relação ao ar exterior respectivo, pode ser explicado pelo fato de que em dias quentes, como o dia da amostragem, as janelas do escritório permaneceram fechadas para manutenção da temperatura ambiente em torno de $23^{\circ} \mathrm{C}$. 
O corredor deste escritório passa na sua periferia, ou seja ele não é confinado, é interno ao escritório, porém fica no centro do edifício, longe das escadarias de acesso, por onde $o$ ar externo pode entrar advindo da porta da rua.

\section{Amostras 6,7,8 e 9}

O edificio onde foram coletadas as amostras 7,8 e 9 possui ar condicionado central, porém os três escritórios amostrados possuem funções e configurações distintas.

A captação de ar deste edifício é voltada para Rua da Consolação e logo em frente existem, em esquinas distintas, dois postos de gasolina, além local de início da subida da Consolação, com cruzamento que apresenta grande movimento de veículos.

Quantitativamente foi encontrado apenas tolueno nas quatro amostras ou seja tanto nas amostras de ar interno como de ar externo.

A única amostra que apresentação mais alta de tolueno no interior foi a amostra 7 , mas este escritório possuía um problema de funcionamento do seu sistema de condicionamento de ar, o qual apresentava problema de insuflação inadequada de ar, nem mesmo o retorno do ar ambiente estava funcionando adequadamente, ou seja a circulação do ar estava precária.

\section{* Amostras 10 e 12}

A amostra 12 pertence a um escritório sem janelas com apenas uma porta e um pequeno balcão para atendimento ao público.

No dia da amostragem o escritório funcionou com a divisória do balcão fechada $\mathrm{e}$ com uma grande quantidade de papeis estocados dentro do mesmo. Estes papéis eram oriundos do vestibular da Universidade, que teve aproximadamente 30.000 candidatos, ou seja todas as provas de um dia de vestibular estavam lá armazenadas.

As concentrações, tanto de benzeno como de tolueno, apresentaram valores dez vezes maior para benzeno e seis vezes maior para tolueno, se comparadas com o as do ar externo.

$\mathrm{O}$ acúmulo de papéis pode ter proporcionado o efeito de absorvedor ("filtro") e concentrado estas substâncias como já observado por Sufert e Abraham (1982). 


\section{* Amostras 11 e 13}

O escritório referente à amostra 13 permaneceu com janelas e portas fechadas o expediente todo, bem como com o ar condicionado (SPLIT) ligado.

A pintura das paredes e portas era recente, com menos de seis meses, sendo um indicativo para o efeito concentrador nos poluentes benzeno e tolueno. A circulação de ar neste escritório é restrita, seus ocupantes pouco se deslocam para outros ambientes. As divisórias de madeira entre as mesas de trabalho tem altura de 1,80 metro e revestimento de carpete colados recentemente.

\section{* Amostras 14 e 15}

Este escritório (15) possui ar condicionado central, porém sua captação é voltada para a Praça Roosevelt e com o agravante de que os filtros do sistema de captação estavam com falta de manutenção. Devido a isso provavelmente houve o efeito concentrador de tetracloreto de carbono e tolueno dentro do escritório.

\section{Amostras 16 e 17}

Neste escritório (17) os trabalhadores preferem ventilação natural. Quando o calor aumenta os trabalhadores deste escritório ligam o condicionador de ar de janela até manter a temperatura entre $22 \mathrm{e} 23^{\circ} \mathrm{C}$, permanecendo com as janelas fechadas por duas ou três horas, mas após esta estabilização eles abrem uma janela para ventilação do ambiente. Devido a isso os valores de benzeno foram praticamente iguais ao obtido no ar externo, sendo que o tolueno ainda apresentou uma concentração maior para o ar interno do para o ar externo provavelmente porque as janelas foram abertas uma vez no dia excepcionalmente.

\section{Amostras 18 e 19}

Mesmo estando o escritório (19) longe de ruas com tráfego de automóveis, as concentrações, tanto no ar externo como no ar interno, apresentaram os mesmos níveis que as outras amostras próximas à ruas. Assim, a idéia de que apenas próximo ao fluxo de automóveis haveria concentrações altas de benzeno e tolueno foi contradita. 
Este escritório possui uma grande área para ventilação, mesmo assim houve aumento na concentração de tolueno em relação a concentração do ar externo. Porém, mesmo com grandes balcões para troca de ar pelo fluxo advindo do corredor, este é pequeno pois o que proporciona a entrada de ar no edificio é apenas uma porta no andar térreo, sendo que as janelas dos corredores ficam semi abertos e que proporcionam uma entrada de ar mínima devido à sua pequena área aberta.

\section{* Amostras 21,20,22 e 23}

Estes escritórios possuem sistema de ar condicionado central. Mesmo a amostra de ar externo (20) tendo indicado as maiores concentrações até então obtidas para tetracloreto de carbono, benzeno e tolueno, os resultados destes escritórios foram de concentrações menores, abaixo da metade do valor externo no caso de tolueno por exemplo.

O sistema deste edifício estava com a manutenção regularizada, com filtros novos e taxa de renovação de ar constante. Os escritórios são pequenos, sendo que o escritório 22 ainda assim permanece com uma janela aberta, sendo que esta ainda está posicionada de frente para uma pequena área arborizada.

\section{* Amostras 25 e 24}

Para o mesmo escritório (23 e 24) em dias distintos ocorreu o mesmo fato, ou seja, a concentração de tolueno no interior, por exemplo foi a metade do valor obtido no ar externo.

A redução da concentração pode se dar nos filtros mesmo estes não sendo próprios para retenção de compostos orgânicos voláteis, ou mesmo pode ocorrer a absorção pelos materiais constantes no escritório bem como nas pessoas que nele trabalham, como citado por Meininghaus e col. (1999).

\section{- Amostras 29 e 26}

Sendo dos mesmos pontos de coleta 1 e 2 , os resultados foram semelhantes aos anteriores, porém no primeiro dia (18/11/2002) a concentração no ar interno para benzeno e tolueno eram menores, porém o efeito concentrador foi mantido. 


\section{Amostras 27 e 28}

Neste dia já não havia mais papéis de vestibular armazenados, como citado na amostragem de 27/11/2002, porém a porta deste escritório é aberta poucas vezes no dia e a circulação de ar é dificultada, devido à posição do escritório no andar onde se encontra, pois ele fica no fundo do corredor de entrada do edificio, porém sem que a porta e o balcão recebam o ar frontalmente advindo da rua.

\section{* Amostras 30 e 31}

Como observado nos dias 3 e 4, houve também uma diminuição da carga poluente, caindo para mais da metade da concentração de benzeno e tolueno, em relação ao ar externo.

\section{Amostras 32 e 33}

O sistema de ar condicionado central foi consertado, ou seja sofreu manutenção nos filtros e parte dos dutos. O resultado, se comparado com as amostras de $27 / 11 / 2002$ (14 e 15) é nítido quanto à mudança de valores, o ar interno apresentou uma concentração de tolueno quase metade do valor obtido no ar externo e para benzeno não foi quantificado no ar interno.

\section{Amostras 34 e 35}

Neste dia o escritório (35) permaneceu com a porta fechada praticamente o expediente todo, devido à manipulação de documentos reservados. Esta poderia ser a causa de um aumento significativo, quase que o dobro da concentração de tolueno no ar. Também, deve-se levar em conta que este dia estava nublado e não foi tão quente, sendo que a diferença entre a temperatura interna do escritório e a do ambiente externo foi mínima.

\section{* Amostras 36 e 37}

Este escritório funciona como secretaria de um colégio e foram realizadas entrevistas com pais que solicitaram transferência neste dia. Para maior conforto o ar condicionado de janela funcionou durante todo o expediente, com raras aberturas de janelas. Este pode ser o motivo para concentração de benzeno e tolueno comparado 
ao ar externo. Também houve grande aglomeração de papéis dentro do escritório durante o expediente, sendo que estes já estavam lá havia dois dias.

O tetracloreto de carbono pode ter surgido através da aplicação de inseticidas na noite anterior pois com o acúmulo de papéis, alguns insetos como baratas podem aparecer devido também ao fato do edifício ser antigo e com piso e teto de madeira.

Amostras 38 e 39

Como citado anteriormente (amostras 18 e 19) a circulação de ar neste edifício é restrita, os vitraux de corredor são poucos e semi abertos. Mesmo este escritório não possuindo contato próximo à ruas movimentadas, isto não impediu a concentração do tolueno.

\section{Amostras 40 e 41}

Os níveis de concentração de tetracloreto de carbono, benzeno e tolueno no ar captado da Praça Roosevelt estavam altos sendo que, com a troca de filtros pode ter conseguido ajudar a diminuir estas concentrações, que no caso do tolueno caiu para um terço do valor do ar externo.

\section{* Amostras 42 e 43}

Este escritório, mesmo não tendo janelas, conseguiu neste dia não concentrar em demasia os poluentes benzeno e tolueno principalmente, devido à colocação de ventiladores nos corredores, pois havia grande fluxo de pessoas no local. Isto propiciou insuflação de ar para dentro do escritório, ajudando na diluição dos poluentes.

\section{Amostras 44 e 45}

As concentrações dos poluentes benzeno e tolueno não foram altas neste dia devido, provavelmente, ao fluxo de pessoas a este escritório, sendo que a porta chegou a ficar aberta por várias horas, para não dificultar a entrada das pessoas. 


\section{- Amostras 46 e 47}

O expediente no edifício este dia foi restrito ao público interno, sendo que a porta de entrada permaneceu fechada, piorando assim a circulação de ar no edifício. Podese atribuir a isso o aumento de concentração, principalmente de tolueno, no ar interno relativo ao ar externo.

Dois dias antes, devido a chuvas, foi necessário o uso de inseticidas, pois alguns insetos entraram no edifício face ao alagamento de uma passagem de pedestres na frente do edificio, motivo este que pode ter alterado a concentração de tetracloreto de carbono no ar interno.

\section{Amostras 48 e 49}

Este escritório que funciona como secretaria de um colégio passou todo expediente com duas janelas abertas e o condicionador de ar ligado, devido a isso os valores internos e externos foram praticamente iguais para tolueno, clorofórmio e tetracloreto de carbono. Porém, na sala ao lado permaneceu, durante todo o expediente, uma pessoa fumante e ao mesmo tempo o fluxo de ar estava no sentido da sala dela para este escritório, durante o dia. Este pode ter sido o motivo da alta concentração de benzeno interna.

\section{Amostras 50 e 51}

Este escritório permaneceu com janelas fechadas o dia todo e acumulou papéis em demasia, devido sua função (elaboração da folha de pagamento), desde o dia 16/12/2002 época de pagamento do $13^{\circ}$ salário, férias e salários para aproximadamente 2000 funcionários. As janelas ficaram fechadas devido à existência de obra em frente ao edificio, que ocasionava muito barulho, pelo uso de britadeiras.

O aumento da concentração de tetracloreto de carbono pode ter ocorrido pela aplicação de inseticida no início da manhã por causa do aparecimento de pernilongos devido às chuvas. 


\section{Amostras 52, 53 e 54}

O escritório da secretaria da presidência da empresa possui o piso revestido com carpete e vários armários de madeira envernizada, com papéis e livros que poderiam concentrar os poluentes, porém mesmo assim isto não ocorreu.

\section{* Considerações gerais}

Os resultados obtidos para tetracloreto de carbono, clorofórmio, benzeno e tolueno não diferiram dos apresentados por Cheng (2000), Perry (1997), Fantuzzi e col. (1996) e Zabiegala e col. (1999) as quais apresentam análises em ambientes fechados com e sem condicionadores de ar. Em todas estas referências foi citado o problema dos contaminantes do ar externo como principais contaminantes do ar interno. Nos resultados obtidos verifica-se que o fator ventilação e renovação de ar foi marcante quanto à concentração de poluentes no ar interno; Brickus e Aquino Neto (1999) já alertavam para este problema como sendo uma constante nos escritórios e casas comerciais no Brasil. A concentração de poluentes também pode ser atribuída neste estudo ao fato de que todos os escritórios amostrados, sem exceção, ficavam fechados totalmente após o expediente, ou seja não havia troca de ar no período noturno até o início do expediente no dia seguinte. Também segundo relatos dos trabalhadores destes escritórios, todos sem exceção ao chegar ao local de trabalho ligavam o condicionador de ar, no caso de SPLIT ou de janela, sem antes arejar o ambiente, fazendo com que houve circulação no ambiente, sem renovação.

No caso dos edificios com ar condicionado central, estes quando chegavam para o trabalho, já encontravam o sistema funcionando, ou seja o ar já circulava e os trabalhadores não sentiam diferença entre $o$ ar do início do expediente em comparação com o final.

Os resultados quantitativos denotaram uma tendência, pelo menos nos edificios amostrados, de concentração de poluentes onde os condicionadores eram do tipo SPLIT ou janela, e o inverso no caso de condicionadores de ar centrais. Porém, percebemos que estas informações estão intimamente ligadas à circulação de ar dentro do escritório e também a manutenção dos condicionadores de ar. Isto ficou evidente quando das comparações entre resultados do ar interno com o ar externo $\mathrm{e}$ as condições de ventilação e manutenção de cada sistema. 


\subsection{2- Resultados Qualitativos}

As análises pelo modo SCAN (varredura de íons) foram realizadas de forma que, além dos íons das moléculas monitoradas (tetracloreto de carbono, clorofórmio, benzeno e tolueno) também foram identificadas de modo qualitativo as outras substâncias coletadas.

Foram analisadas todas as 54 amostras também no modo SCAN, ou seja foram levantadas as composições qualitativas das amostras com intuito de verificar as substâncias mais abundantes nestas amostras.

Para identificação das substâncias foram utilizadas as bibliotecas internas do Espectrofotômetro de Massas com posterior confirmação de padrões cromatográficos.

Os resultados obtidos nas análises pelo modo SCAN demonstraram que a maioria das substâncias contidas no ar externo foram encontradas no ar interno como apresentado na Tabela 31 . 
Tabela 32- Relação de substâncias encontradas nas amostras de ar externo e interno pelo modo SCAN.

\begin{tabular}{|c|c|c|}
\hline Substância & Ar externo & Ar interno \\
\hline Heptano & $\mathrm{X}$ & $\mathrm{X}$ \\
\hline Octano & $\bar{X}$ & $\mathrm{X}$ \\
\hline Nonano & $\mathrm{X}$ & $\mathrm{X}$ \\
\hline Decano & $\mathrm{X}$ & $\mathrm{X}$ \\
\hline Undecano & $\mathrm{X}$ & $\mathrm{X}$ \\
\hline Dodecano & $\mathrm{X}$ & $\mathrm{X}$ \\
\hline Metil ciclohexano & $\mathrm{X}$ & $\mathrm{X}$ \\
\hline Ciclohexano & $\mathrm{X}$ & - \\
\hline Ciclopenteno & $\mathrm{X}$ & - \\
\hline p-xileno & $\mathrm{X}$ & $\mathrm{X}$ \\
\hline o-xileno & $\mathrm{X}$ & $\mathrm{X}$ \\
\hline m-xileno & $\mathrm{X}$ & $\mathrm{X}$ \\
\hline 1 etil, 2 metil benzeno & $\mathrm{X}$ & - \\
\hline 2 metil heptano & $\mathrm{X}$ & - \\
\hline 1,3 dimetil ciclopentano & $\mathrm{X}$ & - \\
\hline Etilbenzeno & $\mathrm{X}$ & $\mathrm{X}$ \\
\hline $1,2,3$ trimetilbenzeno & $\mathrm{X}$ & $\mathrm{X}$ \\
\hline $1,2,4$ trimetilbenzeno & $\mathrm{X}$ & $\mathrm{X}$ \\
\hline 1,3,5 trimetilbenzeno & $\mathrm{X}$ & $\mathrm{X}$ \\
\hline 1,3 dietilbenzeno & $\mathrm{X}$ & $\mathrm{X}$ \\
\hline 2 butoxi etanol & $\mathrm{X}$ & $\mathrm{X}$ \\
\hline Tricloroctileno & $\mathrm{X}$ & - \\
\hline 1,3 dicloropropano & $\mathrm{X}$ & $\mathrm{X}$ \\
\hline 3 cloro propeno 1 & $\mathrm{X}$ & $X$ \\
\hline 2 cloro propeno 1 & - & $\mathrm{X}$ \\
\hline 1 cloro propeno 1 & - & $\mathrm{X}$ \\
\hline 4 cloro octano & $\mathrm{X}$ & - \\
\hline 1,2 dicloro benzeno & $X$ & $\mathrm{X}$ \\
\hline 1,3 dicloro benzeno & $X$ & $\mathrm{X}$ \\
\hline 1,4 dicloro benzeno & $\mathrm{X}$ & $\mathrm{X}$ \\
\hline $2,2,4$ trimetil pentano & - & $\mathrm{X}$ \\
\hline Tricloroetileno & $\mathrm{X}$ & $\mathrm{X}$ \\
\hline D-limoneno & - & $\mathrm{X}$ \\
\hline$\beta$-pineno & - & $\mathrm{X}$ \\
\hline
\end{tabular}

Nas Tabelas 33 a 56 estão demonstradas as substâncias encontradas no ar interior de cada escritório e a respectiva amostra de ar externo. 
Tabela 33- Comparação entre as amostras 1 e 2 quanto às substâncias encontradas através das análises qualitativas pelo modo SCAN

\begin{tabular}{l|c|c}
\hline \multicolumn{1}{c|}{ Substância } & Amostra 1 (ar ext.) & Amostra 2 (ar int.) \\
\hline Heptano & $\mathrm{X}$ & - \\
\hline Metil ciclohexano & $\mathrm{X}$ & - \\
\hline Octano & $\mathrm{X}$ & $\mathrm{X}$ \\
\hline Nonano & $\mathrm{X}$ & $\mathrm{X}$ \\
\hline Etil benzeno & $\mathrm{X}$ & - \\
\hline m-xileno & $\mathrm{X}$ & $\mathrm{X}$ \\
\hline p-xileno & $\mathrm{X}$ & $\mathrm{X}$ \\
\hline Decano & $\mathrm{X}$ & - \\
\hline $\mathbf{1 , 3 , 5}$ trimetil benzeno & $\mathrm{X}$ & $\mathrm{X}$ \\
\hline $\mathbf{2}$ butoxi etanol & - & $\mathrm{X}$ \\
\hline 1,3 dicloro benzeno & - & $\mathrm{X}$ \\
\hline $\mathbf{1 , 4}$ dicloro benzeno & - & $\mathrm{X}$ \\
\hline d-limoneno & - & $\mathrm{X}$ \\
\hline
\end{tabular}

As substâncias 1,3 dicloro benzeno e 1,4 dicloro benzeno podem advir de odorizadores que são utilizados neste ambiente ou produtos de limpeza (Bloemen e Burn, 1995). O D-limoneno pode ter como fontes as mesmas coitadas anteriormente bem como a cera utilizada no piso de PVC (ECA,1997). O 2 butoxi etanol não é característico das fontes internas deste escritório, porém pode ser proveniente de fonte externa como a queima incompleta do etanol combustível (EMA, 2000). 
Tabela 34- Comparação entre as amostras 3, 4 e 5 quanto às substâncias encontradas através das análises qualitativas pelo modo SCAN

\begin{tabular}{|c|c|c|c|}
\hline SUBSTÂNCIA & Amostra 3 (ar ext.) & Amostra 4 (ar int.) & Amostra 5 (ar int.) \\
\hline o-xileno & $\bar{X}$ & - & $\mathrm{X}$ \\
\hline Decano & $\mathrm{X}$ & $\mathrm{X}$ & $\mathrm{X}$ \\
\hline p-xileno & $\mathrm{X}$ & - & $\mathrm{X}$ \\
\hline 1 etil, 2 metil benzeno & $\mathrm{X}$ & - & - \\
\hline $1,2,4$ trimetil benzeno & $\mathrm{X}$ & $\mathrm{X}$ & - \\
\hline Metil ciclohexano & $\mathrm{X}$ & $\mathrm{X}$ & $\mathrm{X}$ \\
\hline Octano & - & $\mathrm{X}$ & - \\
\hline Nonano & - & $X$ & - \\
\hline Etil benzeno & - & $\mathrm{X}$ & $\mathrm{X}$ \\
\hline 1,2 dicloro benzeno & - & $\mathrm{X}$ & - \\
\hline 1,3 dicloro benzeno & - & $\mathrm{X}$ & - \\
\hline 1,4 dicloro benzeno & - & $\mathrm{X}$ & - \\
\hline 2 butoxi etanol & - & $\mathrm{X}$ & - \\
\hline $2,2,4$ trimetil pentano & - & - & $\mathrm{X}$ \\
\hline 1,3,5 trimetil benzeno & - & - & $\mathrm{X}$ \\
\hline m-xileno & $\mathrm{X}$ & - & - \\
\hline Heptano & $\mathrm{X}$ & - & $\mathrm{X}$ \\
\hline
\end{tabular}

O nonano, trimetil benzeno e etil benzeno podem ser provenientes da cera passada no piso (ECA, 1997). Os dicloro benzeno podem advir de odorizadores ou produtos de limpeza (Bloemen e Burn, 1995). O 2,2,4 trimetil pentano é um constituinte comum da gasolina (EMA, 2000). 
Tabela 35- Comparação entre as amostras $6,7,8$ e 9 quanto às substâncias encontradas através das análises qualitativas pelo modo SCAN

\begin{tabular}{l|c|c|c|c}
\hline \multicolumn{1}{c|}{ SUBSTÂNCIA } & $\begin{array}{c}\text { Amostra 6 } \\
\text { (ar ext.) }\end{array}$ & $\begin{array}{c}\text { Amostra 7 } \\
\text { (ar int.) }\end{array}$ & $\begin{array}{c}\text { Amostra 8 } \\
\text { (ar int.) }\end{array}$ & $\begin{array}{c}\text { Amostra 9 } \\
\text { (ar int.) }\end{array}$ \\
\hline Nonano & $\mathrm{X}$ & & & \\
\hline p-xileno & $\mathrm{X}$ & & & \\
\hline 2 butoxi etanol & $\mathrm{X}$ & $\mathrm{X}$ & $\mathrm{X}$ & $\mathrm{X}$ \\
\hline Etil benzeno & $\mathrm{X}$ & & & \\
\hline m-xileno & $\mathrm{X}$ & $\mathrm{X}$ & $\mathrm{X}$ & $\mathrm{X}$ \\
\hline o-xileno & $\mathrm{X}$ & $\mathrm{X}$ & & \\
\hline 2 cloro propeno 1 & & $\mathrm{X}$ & & \\
\hline 3 cloro propeno 1 & & $\mathrm{X}$ & & $\mathrm{X}$ \\
\hline 1,2 dicloro benzeno & & & & $\mathrm{X}$ \\
\hline 1,3 dicloro benzeno & & & & $\mathrm{X}$ \\
\hline 1,4 dicloro benzeno & & & & $\mathrm{X}$ \\
\hline D-limoneno & & & & \\
\hline
\end{tabular}

Os dicloro benzeno podem advir de odorizadores ou produtos de limpeza (Bloemen e Burn, 1995). Quanto aos cloro propeno, são comumente usados como propelentes em aerossóis (Bloemen e Burn, 1995). O D-limoneno pode ser proveniente de materiais de limpeza (Bloemen e Burn, 1995).

Tabela 36- Comparação entre as amostras 10 e 12 quanto às substâncias encontradas através das análises qualitativas pelo modo SCAN

\begin{tabular}{l|c|c}
\hline \multicolumn{1}{c|}{ SUBSTÂNCIA } & Amostra 10 (ar ext.) & Amostra 12 (ar int.) \\
\hline Nonano & $\mathrm{X}$ & $\mathrm{X}$ \\
\hline p-xileno & $\mathrm{X}$ & $\mathrm{X}$ \\
\hline 1,3 dicloro benzeno & $\mathrm{X}$ & $\mathrm{X}$ \\
\hline Etil benzeno & $\mathrm{X}$ & $\mathrm{X}$ \\
\hline Octano & & $\mathrm{X}$ \\
\hline 1,4 dicloro benzeno & & $\mathrm{X}$ \\
\hline 1 etil 2 metil benzeno & $\mathrm{X}$ & $\mathrm{X}$ \\
\hline 1,2 dicloro benzeno & & $\mathrm{X}$ \\
\hline $1,2,4$ trimetil benzeno & & $\mathrm{X}$ \\
\hline
\end{tabular}

Os dicloro benzeno podem advir de odorizadores ou produtos de limpeza (Bloemen e Burn, 1995). O octano pode proceder da tinta que reveste as paredes pois estas são recentes, menos de seis meses (ECA, 1997). O tri metil benzeno pode advir da cera passada no piso de PVC do escritório (ECA, 1997). 
Tabela 37- Comparação entre as amostras 11 e 13 quanto às substâncias encontradas através das análises qualitativas pelo modo SCAN

\begin{tabular}{l|c|c}
\hline \multicolumn{1}{c|}{ SUBSTÂNCLAS } & Amostra 11 (ar ext.) & Amostra 13 (ar int.) \\
\hline 1,3 dicloro propano & $\mathrm{X}$ & \\
\hline Nonano & $\mathrm{X}$ & $\mathrm{X}$ \\
\hline p-xileno & $\mathrm{X}$ & $\mathrm{X}$ \\
\hline 1 etil 2 metil benzeno & $\mathrm{X}$ & $\mathrm{X}$ \\
\hline Etil benzeno & & $\mathrm{X}$ \\
\hline 1,4 dicloro benzeno & & $\mathrm{X}$ \\
\hline 1,3 dicloro benzeno & & \\
\hline
\end{tabular}

O etilbenzeno pode proceder da cera passada no piso de PVC do escritório (ECA, 1997).

O dicloro benzeno pode advir de odorizadores ou produtos de limpeza (Bloemen e Burn, 1995).

Tabela 38- Comparação entre as amostras 14 e 15 quanto as substâncias encontradas através das análises qualitativas pelo modo SCAN

\begin{tabular}{l|c|c}
\hline \multicolumn{1}{c|}{ SUBSTÂNCIA } & Amostra 14 (ar ext.) & Amostra 15 (ar int.) \\
\hline 0-xileno & $\mathrm{X}$ & $\mathrm{X}$ \\
\hline 4 cloro octano & $\mathrm{X}$ & $\mathrm{X}$ \\
\hline $1,3,5$ trimetil benzeno & $\mathrm{X}$ & $\mathrm{X}$ \\
\hline 1,4 dicloro benzeno & & $\mathrm{X}$ \\
\hline Etil benzeno & & $\mathrm{X}$ \\
\hline m-xileno & & $\mathrm{X}$ \\
\hline 1,3 dicloro benzeno & & $\mathrm{X}$ \\
\hline Decano & & $\mathrm{X}$ \\
\hline 1,2 dicloro benzeno & & \\
\hline
\end{tabular}

O m-xileno pode ser procedente dos estofados de vinil (ECA, 1997).

O decano pode ser proveniente da cera passada no piso (ECA, 1997). O etilbenzeno pode proceder da cera passada no piso de PVC do escritório (ECA, 1997). 
Tabela 39- Comparação entre as amostras 16 e 17 quanto as substâncias encontradas através das análises qualitativas pelo modo SCAN

\begin{tabular}{l|c|c}
\hline \multicolumn{1}{c|}{ SUBSTÂNCIA } & Amostra 16 (ar ext.) & Amostra 17 (ar int.) \\
\hline 1,3 dicloro benzeno & & $\mathrm{X}$ \\
\hline Etil benzeno & $\mathrm{X}$ & \\
\hline o-xileno & $\mathrm{X}$ & $\mathrm{X}$ \\
\hline Nonano & & $\mathrm{X}$ \\
\hline m-xileno & & $\mathrm{X}$ \\
\hline D-limoneno & & $\mathrm{X}$ \\
\hline $1,3,5$ trimetil benzeno & & $\mathrm{X}$ \\
\hline 1,3 dicloro propano & $\mathrm{X}$ & \\
\hline
\end{tabular}

O nonano e o trimetil benzeno podem advir da cera passada no piso (ECA, 1997).

O m-xileno pode ser procedente dos estofados de vinil (ECA, 1997).

O dicloro benzeno pode advir de odorizadores ou produtos de limpeza (Bloemen e Burn, 1995).

O D-limoneno deve advir principalmente da cera passada no piso de madeira, pois este geralmente está em excesso no piso (ECA, 1997).

Tabela 40- Comparação entre as amostras 18 e 19 quanto as substâncias encontradas através das análises qualitativas pelo modo SCAN

\begin{tabular}{l|c|c}
\hline \multicolumn{1}{c|}{ SUBSTÂNCIA } & Amostra 18 (ar ext.) & Amostra 19 (ar int.) \\
\hline $\mathbf{1 , 3}$ dicloro propano & $\mathrm{X}$ & $\mathrm{X}$ \\
\hline m-xileno & $\mathrm{X}$ & $\mathrm{X}$ \\
\hline Decano & $\mathrm{X}$ & $\mathrm{X}$ \\
\hline $\mathbf{1 , 3 , 5}$ trimetil benzeno & $\mathrm{X}$ & $\mathrm{X}$ \\
\hline Nonano & $\mathrm{X}$ & $\mathrm{X}$ \\
\hline $\mathbf{1 , 2 , 4}$ trimetil benzeno & $\mathrm{X}$ & $\mathrm{X}$ \\
\hline $\mathbf{2 , 3 \text { dimetil heptano }}$ & & $\mathrm{X}$ \\
\hline $\mathbf{1 , 4}$ dicloro benzeno & & $\mathrm{X}$ \\
\hline Etil benzeno & & $\mathrm{X}$ \\
\hline $\mathbf{2}$ butoxi etanol & & $\mathrm{X}$ \\
\hline 1,3 dicloro benzeno & & \\
\hline D-limoneno & & \\
\hline
\end{tabular}

O 2,3 dimetil heptano é uma substância característica da gasolina (EMA, 2000).

O 2 butoxi etanol não é característico das fontes internas deste escritório, porém pode ser proveniente de fonte externa como a queima incompleta do etanol combustivel (EMA, 2000). 
Os dicloro benzeno podem advir de odorizadores ou produtos de limpeza (Bloemen e Burn, 1995).

O D-limoneno e o etilbenzeno devem advir principalmente da cera passada no piso (ECA, 1997).

Tabela 41- Comparação entre as amostras 21, 20, 22 e 23 quanto as substâncias encontradas através das análises qualitativas pelo modo SCAN

\begin{tabular}{l|c|c|c|c}
\hline \multicolumn{1}{c|}{ SUBSTÂNCIA } & $\begin{array}{c}\text { Amostra 21 } \\
\text { (ar ext.) }\end{array}$ & $\begin{array}{c}\text { Amostra 20 } \\
\text { (ar int.) }\end{array}$ & $\begin{array}{c}\text { Amostra 22 } \\
\text { (ar int.) }\end{array}$ & $\begin{array}{c}\text { Amostra 23 } \\
\text { (ar int.) }\end{array}$ \\
\hline $\mathbf{2}$ metil pentano & $\mathrm{X}$ & & & \\
\hline Octano & $\mathrm{X}$ & & & \\
\hline Nonano & $\mathrm{X}$ & $\mathrm{X}$ & $\mathrm{X}$ & $\mathrm{X}$ \\
\hline Decano & $\mathrm{X}$ & $\mathrm{X}$ & $\mathrm{X}$ & $\mathrm{X}$ \\
\hline Undecano & $\mathrm{X}$ & & & \\
\hline Dodecano & $\mathrm{X}$ & & & \\
\hline m-xileno & $\mathrm{X}$ & $\mathrm{X}$ & $\mathrm{X}$ & \\
\hline $\mathbf{p}-\mathbf{x i l e n o}$ & $\mathrm{X}$ & & & $\mathrm{X}$ \\
\hline $\mathbf{1 , 3}$ dicloro benzeno & $\mathrm{X}$ & $\mathrm{X}$ & & $\mathrm{X}$ \\
\hline $\mathbf{1 , 4}$ dicloro benzeno & $\mathrm{X}$ & $\mathrm{X}$ & & \\
\hline $\mathbf{1 , 3 , 5}$ trimetil benzeno & $\mathrm{X}$ & $\mathrm{X}$ & & $\mathrm{X}$ \\
\hline $\mathbf{3 , 7}$ dimetil decano & $\mathrm{X}$ & & & \\
\hline Etil benzeno & & $\mathrm{X}$ & $\mathrm{X}$ & $\mathrm{X}$ \\
\hline D-limoneno & & $\mathrm{X}$ & $\mathrm{X}$ & $\mathrm{X}$ \\
\hline $\mathbf{2 , 3}$ dimetil heptano & & & $\mathrm{X}$ & \\
\hline $\mathbf{1 , 3}$ dicloro propano & & & $\mathrm{X}$ & \\
\hline $\mathbf{2 , 2}$ dimetil decano & & & $\mathrm{X}$ & \\
\hline B-pineno & & & $\mathrm{X}$ & $\mathrm{X}$ \\
\hline 1etil 2 metil benzeno & & & $\mathrm{X}$ & \\
\hline Terc butil benzeno & & & $\mathrm{X}$ & \\
\hline
\end{tabular}

O D-limoneno, $\beta$-pineno, 1 etil 2 metil benzeno e o etilbenzeno devem advir principalmente da cera passada no piso (ECA, 1997).

Os dicloro propano são substâncias utilizadas como propelentes em aerossóis (Bloemen e Burn, 1995).

O 2,3 dimetil heptano é uma substância característica da gasolina (EMA, 2000).

O 2,2 dimetil decano pode ser proveniente da cera passada no piso (ECA, 1997).

$\mathrm{O}$ terc butil benzeno pode advir de óleo específico para proteção de madeira de divisória (ECA, 1997). 
Tabela 42- Comparação entre as amostras 25 e 24 quanto as substâncias encontradas através das análises qualitativas pelo modo SCAN

\begin{tabular}{l|c|c}
\hline \multicolumn{1}{c|}{ SUBSTÂNCIA } & Amostra 25 (ar ext.) & Amostra 24 (ar int.) \\
\hline Nonano & $\mathrm{X}$ & $\mathrm{X}$ \\
\hline Etil benzeno & $\mathrm{X}$ & $\mathrm{X}$ \\
\hline $\mathbf{m}$-xileno & $\mathrm{X}$ & $\mathrm{X}$ \\
\hline Decano & $\mathrm{X}$ & $\mathrm{X}$ \\
\hline $\mathbf{1 , 3 , 5}$ trimetil benzeno & $\mathrm{X}$ & $\mathrm{X}$ \\
\hline $\mathbf{1 , 3 \text { dicloro benzeno }}$ & & $\mathrm{X}$ \\
\hline D-limoneno & & $\mathrm{X}$ \\
\hline$\beta$-pineno & & $\mathrm{X}$ \\
\hline p-xileno & & \\
\hline
\end{tabular}

Os dicloro benzeno podem advir de odorizadores ou produtos de limpeza (Bloemen e Burn, 1995).

O D-limoneno e o $\beta$-pineno devem advir principalmente da cera passada no piso (ECA, 1997). O p-xileno pode ser encontrado na cera passada no piso (ECA, 1997).

Tabela 43- Comparação entre as amostras 29 e 26 quanto as substâncias encontradas através das análises qualitativas pelo modo SCAN

\begin{tabular}{l|c|c}
\hline \multicolumn{1}{c|}{ SUBSTÂNCIAS } & Amostra 29 (ar ext.) & Amostra 26 (ar int.) \\
\hline Nonano & $\mathrm{X}$ & $\mathrm{X}$ \\
\hline Etil benzeno & $\mathrm{X}$ & $\mathrm{X}$ \\
\hline m-xileno & $\mathrm{X}$ & $\mathrm{X}$ \\
\hline Decano & $\mathrm{X}$ & $\mathrm{X}$ \\
\hline $\mathbf{1 , 3 , 5 \text { trimetil benzeno }}$ & $\mathrm{X}$ & $\mathrm{X}$ \\
\hline Octano & $\mathrm{X}$ & $\mathrm{X}$ \\
\hline 2 butoxi etanol & & $\mathrm{X}$ \\
\hline 1,3 dicloro benzeno & & $\mathrm{X}$ \\
\hline $\mathbf{1 , 2}$ dicloro benzeno & & $\mathrm{X}$ \\
\hline
\end{tabular}

O 2 butoxi etanol não é característico das fontes internas deste escritório, porém pode ser proveniente de fonte externa como a queima incompleta do etanol combustivel (EMA, 2000). Os dicloro benzeno podem advir de odorizadores ou produtos de limpeza (Bloemen e Burn, 1995). O 1 etil 2,4 dimetil benzeno pode ser encontrado na cera passada no piso (ECA, 1997). 
Tabela 44- Comparação entre as amostras 27 e 28 quanto as substâncias encontradas através das análises qualitativas pelo modo SCAN

\begin{tabular}{l|c|c}
\hline \multicolumn{1}{c|}{ SUBSTÂNCIAS } & Amostra 27 (ar ext.) & Amostra 28 (ar int.) \\
\hline Nonano & $\mathrm{X}$ & $\mathrm{X}$ \\
\hline Etil benzeno & $\mathrm{X}$ & $\mathrm{X}$ \\
\hline $\mathbf{p}$-xileno & $\mathrm{X}$ & $\mathrm{X}$ \\
\hline $\mathbf{1 , 3}$ dicloro benzeno & $\mathrm{X}$ & \\
\hline Decano & $\mathrm{X}$ & \\
\hline $\mathbf{1 , 2}$ dicloro benzeno & $\mathrm{X}$ & $\mathrm{X}$ \\
\hline Octano & $\mathrm{X}$ & $\mathrm{X}$ \\
\hline $\mathbf{m - x i l e n o}$ & & $\mathrm{X}$ \\
\hline $\mathbf{2}$ butoxi etanol & & $\mathrm{X}$ \\
\hline $\mathbf{1 , 3 , 5}$ trimetil benzeno & & $\mathrm{X}$ \\
\hline D-limoneno & & $\mathrm{X}$ \\
\hline $\mathbf{2 , 4 , 4 \text { trimetil benzeno }}$ & &
\end{tabular}

Os trimetil benzeno bem como o D-limoneno e o m-xileno podem advir da cera passada no piso (ECA, 1997). Porém estes com exceção do D-limoneno também provir da tinta das paredes (Bloemen e Burn, 1995). O 2 butoxi etanol não é característico das fontes internas deste escritório, porém pode ser proveniente de fonte externa como a queima incompleta do etanol combustível (EMA, 2000).

Tabela 45- Comparação entre as amostras 30 e 31 quanto as substâncias encontradas através das análises qualitativas pelo modo SCAN

\begin{tabular}{l|c|c}
\hline \multicolumn{1}{c|}{ SUBSTÁNCIAS } & Amostra 30 (ar ext.) & Amostra 31 (ar int.) \\
\hline Nonano & $\mathrm{X}$ & \\
\hline Etil benzeno & $\mathrm{X}$ & $\mathrm{X}$ \\
\hline m-xileno & $\mathrm{X}$ & $\mathrm{X}$ \\
\hline Decano & $\mathrm{X}$ & $\mathrm{X}$ \\
\hline $\mathrm{p}$-xileno & $\mathrm{X}$ & \\
\hline 1,3,5 trimetil benzeno & $\mathrm{X}$ & $\mathrm{X}$ \\
\hline 1,3 dicloro benzeno & $\mathrm{X}$ & \\
\hline Undecano & $\mathrm{X}$ & $\mathrm{X}$ \\
\hline 1 etil 2 metil benzeno & $\mathrm{X}$ & \\
\hline 1,4 dicloro benzeno & $\mathrm{X}$ & $\mathrm{X}$ \\
\hline Dodecano & $\mathrm{X}$ & $\mathrm{X}$ \\
\hline D-limoneno & & \\
\hline 2 butoxi etanol & & \\
\hline
\end{tabular}


O D-limoneno pode advir da cera passada no piso (ECA, 1997) ou dos produtos de limpeza (Bloemen e Burn, 1995).

O 2 butoxi etanol não é característico das fontes internas deste escritório, porém pode ser proveniente de fonte externa como a queima incompleta do etanol combustivel (EMA, 2000).

Tabela 46- Comparação entre as amostras 32 e 33 quanto as substâncias encontradas através das análises qualitativas pelo modo SCAN

\begin{tabular}{l|c|c}
\hline \multicolumn{1}{c|}{ SUBSTÁNCIAS } & Amostra 32 (ar ext.) & Amostra 33 (ar int.) \\
\hline 2 metil heptano & $\mathrm{X}$ & \\
\hline Octano & $\mathrm{X}$ & $\mathrm{X}$ \\
\hline Nonano & $\mathrm{X}$ & $\mathrm{X}$ \\
\hline Decano & $\mathrm{X}$ & $\mathrm{X}$ \\
\hline m-xileno & $\mathrm{X}$ & $\mathrm{X}$ \\
\hline p-xileno & $\mathrm{X}$ & $\mathrm{X}$ \\
\hline $1,3,5$ trimetil benzeno & $\mathrm{X}$ & $\mathrm{X}$ \\
\hline 1,3 dicloro benzeno & & $\mathrm{X}$ \\
\hline 1,4 dicloro benzeno & & $\mathrm{X}$ \\
\hline Etilbenzeno & & \\
\hline D-limoneno & & \\
\hline 1,2 dicloro benzeno & & \\
\hline
\end{tabular}

Os dicloro benzeno podem advir de odorizadores ou produtos de limpeza (Bloemen e Burn, 1995).

O D-limoneno e o etilbenzeno devem advir principalmente da cera passada no piso (ECA, 1997), sendo que o D-limoneno pode proceder também de alguns produtos de limpeza (Bloemen e Burn, 1995). 
Tabela 47- Comparação entre as amostras 34 e 35 quanto as substâncias encontradas através das análises qualitativas pelo modo SCAN

\begin{tabular}{l|c|c}
\hline \multicolumn{1}{c|}{ SUBSTÂNCIAS } & Amostra 34 (ar ext.) & Amostra 35 (ar int.) \\
\hline Nonano & $\mathrm{X}$ & $\mathrm{X}$ \\
\hline Etil benzeno & $\mathrm{X}$ & $\mathrm{X}$ \\
\hline m-xileno & $\mathrm{X}$ & $\mathrm{X}$ \\
\hline Decano & $\mathrm{X}$ & $\mathrm{X}$ \\
\hline $\mathbf{1 , 3}$ dicloro benzeno & & $\mathrm{X}$ \\
\hline $\mathbf{2 , 3 \text { dimetil heptano }}$ & & $\mathrm{X}$ \\
\hline $\mathbf{1}$ metil $\mathbf{2}$ etil benzeno & & $\mathrm{X}$ \\
\hline D-limoneno & & $\mathrm{X}$ \\
\hline $\mathbf{1 , 3 , 5}$ trimetil benzeno & & $\mathrm{X}$ \\
\hline $\mathbf{1 , 2 , 3 \text { trimetil benzeno }}$ & & $\mathrm{X}$ \\
\hline $\mathbf{1 , 4}$ dicloro benzeno & & $\mathrm{X}$ \\
\hline
\end{tabular}

O 2,3 dimetil heptano é uma substância característica da gasolina (EMA, 2000).

Os trimetil benzeno e o 1 metil 2 etil benzeno podem proceder da cera passada no piso (ECA, 1997).

Os trimetil benzeno também podem advir dos carpetes colados nas divisórias das mesas de trabalho (ECA, 1997).

Os dicloro benzeno podem advir de odorizadores ou produtos de limpeza (Bloemen e Burn, 1995).

Tabela 48- Comparação entre as amostras 36 e 37 quanto as substâncias encontradas através das análises qualitativas pelo modo SCAN

\begin{tabular}{l|c|c}
\hline \multicolumn{1}{c|}{ SUBSTÂNCIAS } & Amostra 36 (ar ext.) & Amostra 37 (ar int.) \\
\hline Etil benzeno & $\mathrm{X}$ & $\mathrm{X}$ \\
\hline m-xileno & $\mathrm{X}$ & $\mathrm{X}$ \\
\hline p-xileno & $\mathrm{X}$ & \\
\hline Decano & $\mathrm{X}$ & $\mathrm{X}$ \\
\hline $\mathbf{1 , 2 , 4}$ trimetil benzeno & $\mathrm{X}$ & $\mathrm{X}$ \\
\hline $\mathbf{1 , 3}$ dicloro propano & & \\
\hline
\end{tabular}

O 1,3 dicloro propano é uma substância caracteristicamente utilizada com propelente em aerossóis (Bloemen e Burn, 1995). 
Tabela 49- Comparação entre as amostras 38 e 39 quanto as substâncias encontradas através das análises qualitativas pelo modo SCAN

\begin{tabular}{l|c|c}
\hline \multicolumn{1}{c|}{ SUBSTÂNCIAS } & Amostra 38 (ar ext.) & Amostra 39 (ar int.) \\
\hline Etil benzeno & $\mathrm{X}$ & $\mathrm{X}$ \\
\hline p-xileno & $\mathrm{X}$ & $\mathrm{X}$ \\
\hline $\mathbf{1 , 3 , 5}$ trimetil benzeno & $\mathrm{X}$ & $\mathrm{X}$ \\
$\mathbf{1 , 3 \text { dicloro benzeno }}$ & $\mathrm{X}$ & $\mathrm{X}$ \\
\hline Decano & $\mathrm{X}$ & $\mathrm{X}$ \\
\hline $\mathbf{1 , 4 \text { dicloro benzeno }}$ & $\mathrm{X}$ & $\mathrm{X}$ \\
\hline D-limoneno & & $\mathrm{X}$ \\
\hline $\mathbf{2}$ butoxi etanol & & $\mathrm{X}$ \\
\hline 1,2 dicloro benzeno & & \\
\hline
\end{tabular}

O D-limoneno pode ser proveniente da cera passada no piso ou dos produtos de limpeza utilizados no ambiente (ECA, 1997).

Os dicloro benzeno podem advir de odorizadores ou produtos de limpeza (Bloemen e Burn, 1995).

O 2-butoxi etanol não é característico das fontes internas deste escritório, porém pode ser proveniente de fonte externa como a queima incompleta do etanol combustivel (EMA, 2000).

Tabela 50- Comparação entre as amostras 40 e 41 quanto as substâncias encontradas através das análises qualitativas pelo modo SCAN

\begin{tabular}{l|c|c}
\hline \multicolumn{1}{c|}{ SUBSTÂNCIAS } & Amostra 40 (ar ext.) & Amostra 41 (ar int.) \\
\hline 1,3 dicloro propano & $\mathrm{X}$ & \\
\hline 2,3 dimetil heptano & $\mathrm{X}$ & $\mathrm{X}$ \\
\hline Nonano & $\mathrm{X}$ & $\mathrm{X}$ \\
\hline Etil benzeno & $\mathrm{X}$ & $\mathrm{X}$ \\
\hline p-xileno & $\mathrm{X}$ & $\mathrm{X}$ \\
\hline o-xileno & $\mathrm{X}$ & $\mathrm{X}$ \\
\hline Decano & $\mathrm{X}$ & $\mathrm{X}$ \\
\hline 1,3,5 trimetil benzeno & $\mathrm{X}$ & $\mathrm{X}$ \\
\hline Heptano & & $\mathrm{X}$ \\
\hline Metil ciclohexano & & $\mathrm{X}$ \\
\hline 2 metil heptano & $\mathrm{X}$ & $\mathrm{X}$ \\
\hline Octano & & $\mathrm{X}$ \\
\hline m-xileno & & $\mathrm{X}$ \\
\hline 1 etil 2 metil benzeno & & \\
\hline D-limoneno & & \\
\hline
\end{tabular}


O metil ciclohexano e o m-xileno podem provir dos estofados de vinil (ECA, 1997).

O 2 metil heptano é uma substância característica da gasolina (EMA, 2000).

O D-limoneno e o 1 etil 2-metil benzeno devem advir principalmente da cera passada no piso (ECA, 1997).

Tabela 51- Comparação entre as amostras 42 e 43 quanto as substâncias encontradas através das análises qualitativas pelo modo SCAN

\begin{tabular}{l|c|c}
\hline \multicolumn{1}{c|}{ SUBSTÂNCIAS } & Amostra 42 (ar ext.) & Amostra 43 (ar int.) \\
\hline Metil ciclohexano & $\mathrm{X}$ & $\mathrm{X}$ \\
\hline Octano & $\mathrm{X}$ & $\mathrm{X}$ \\
\hline Etil benzeno & $\mathrm{X}$ & $\mathrm{X}$ \\
\hline m-xileno & $\mathrm{X}$ & $\mathrm{X}$ \\
\hline Decano & $\mathrm{X}$ & $\mathrm{X}$ \\
\hline o-xileno & $\mathrm{X}$ & $\mathrm{X}$ \\
\hline Nonano & $\mathrm{X}$ & \\
\hline 1-etil 2-metil benzeno & $\mathrm{X}$ & $\mathrm{X}$ \\
\hline Heptano & & $\mathrm{X}$ \\
\hline p-xileno & & $\mathrm{X}$ \\
\hline 2-butoxi etanol & & $\mathrm{X}$ \\
\hline 1,2,3-trimetil benzeno & & $\mathrm{X}$ \\
\hline 1,3,5-trimetil benzeno & & $\mathrm{X}$ \\
\hline Undecano & &
\end{tabular}

O heptano, p-xileno, os trimetil benzeno e o undecano podem ter como fonte a cera passada no piso (ECA, 1997).

Estas substâncias também podem advir da tinta passada nas paredes do escritório (Bloemen e Burn, 1995).

O 2-butoxi etanol não é característico das fontes internas deste escritório, porém pode ser proveniente de fonte externa como a queima incompleta do etanol combustivel (EMA, 2000). 
Tabela 52- Comparação entre as amostras 44 e 45 quanto as substâncias encontradas através das análises qualitativas pelo modo SCAN

\begin{tabular}{l|c|c}
\hline \multicolumn{1}{c|}{ SUBSTÂNCIAS } & Amostra 44 (ar ext.) & Amostra 45 (ar int.) \\
\hline $\mathbf{1 , 3}$ dicloro propano & $\mathrm{X}$ & $\mathrm{X}$ \\
\hline 3 cloro propeno 1 & $\mathrm{X}$ & $\mathrm{X}$ \\
\hline Nonano & $\mathrm{X}$ & $\mathrm{X}$ \\
\hline Etil benzeno & $\mathrm{X}$ & $\mathrm{X}$ \\
\hline m-xileno & $\mathrm{X}$ & $\mathrm{X}$ \\
\hline p-xileno & $\mathrm{X}$ & \\
\hline 1,3 dicloro benzeno & $\mathrm{X}$ & \\
\hline 1,4 dicloro benzeno & $\mathrm{X}$ & $\mathrm{X}$ \\
\hline $\mathbf{1}$ etil 2 metil benzeno & $\mathrm{X}$ & $\mathrm{X}$ \\
\hline Metil ciclohexano & & $\mathrm{X}$ \\
\hline $\mathbf{1 , 2 , 4 \text { trimetil benzeno }}$ & & $\mathrm{X}$ \\
\hline Decano & & $\mathrm{X}$ \\
\hline $\mathbf{1 , 2 , 3 \text { trimetil benzeno }}$ & & $\mathrm{X}$ \\
\hline $1,3,5$ trimetil benzeno & & \\
\hline
\end{tabular}

Os trimetil benzeno e o decano podem advir da cera passada no chão ou dos carpetes colados nas divisórias de madeira (ECA, 1997).

O metil ciclohexano e o m-xileno podem provir dos estofados de vinil (ECA, 1997).

Tabela 53- Comparação entre as amostras 46 e 47 quanto as substâncias encontradas através das análises qualitativas pelo modo SCAN

\begin{tabular}{l|c|c}
\hline \multicolumn{1}{c|}{ SUBSTÁNCIAS } & Amostra 46 (ar ext.) & Amostra 47 (ar int.) \\
\hline Heptano & $\mathrm{X}$ & \\
\hline Nonano & $\mathrm{X}$ & \\
\hline Decano & $\mathrm{X}$ & $\mathrm{X}$ \\
\hline Etil benzeno & $\mathrm{X}$ & $\mathrm{X}$ \\
\hline p-xileno & $\mathrm{X}$ & $\mathrm{X}$ \\
\hline o-xileno & $\mathrm{X}$ & $\mathrm{X}$ \\
\hline 1,3 dicloro benzeno & $\mathrm{X}$ & \\
\hline 1 etil 2 metil benzeno & $\mathrm{X}$ & $\mathrm{X}$ \\
\hline $1,3,5$ trimetil benzeno & $\mathrm{X}$ & $\mathrm{X}$ \\
\hline Metil ciclohexano & & $\mathrm{X}$ \\
\hline $\mathbf{2}$ butoxi etanol & & $\mathrm{X}$ \\
\hline D-limoneno & & $\mathrm{X}$ \\
\hline 1,4 dicloro benzeno & & $\mathrm{X}$ \\
\hline $\mathbf{2}$ metil nonano & & \\
\hline
\end{tabular}


O D-limoneno e o 2 metil nonano podem provir da cera passada (ECA, 1997). O metil ciclohexano e o m-xileno podem provir dos estofados de vinil (ECA, 1997). Os dicloro benzeno podem advir de odorizadores ou produtos de limpeza (Bloemen e Burn, 1995).

O 2 butoxi etanol não é característico das fontes internas deste escritório, porém pode ser proveniente de fonte externa como a queima incompleta do etanol combustível (EMA, 2000).

Tabela 54- Comparação entre as amostras 48 e 49 quanto as substâncias encontradas através das análises qualitativas pelo modo SCAN

\begin{tabular}{l|c|c}
\hline \multicolumn{1}{c|}{ SUBSTÂNCIAS } & Amostra 48 (ar ext.) & Amostra 49 (ar int.) \\
\hline Heptano & $\mathrm{X}$ & \\
\hline o-xileno & $\mathrm{X}$ & $\mathrm{X}$ \\
\hline p-xileno & $\mathrm{X}$ & \\
\hline 1 cloro 3 metil butano & $\mathrm{X}$ & $\mathrm{X}$ \\
\hline m-xileno & $\mathrm{X}$ & $\mathrm{X}$ \\
\hline $\mathbf{1 , 3 , 5 \text { trimetil benzeno }}$ & $\mathrm{X}$ & $\mathrm{X}$ \\
\hline Nonano & & $\mathrm{X}$ \\
\hline Decano & & \\
\hline D-limoneno & & \\
\hline
\end{tabular}

O nonano, o decano e o D-limoneno podem advir da cera passada no piso de PVC do escritório (ECA, 1997). 
Tabela 55- Comparação entre as amostras 50 e 51 quanto as substâncias encontradas através das análises qualitativas pelo modo SCAN

\begin{tabular}{l|c|c}
\hline \multicolumn{1}{c|}{ SUBSTÂNCIAS } & Amostra 50 (ar ext.) & Amostra 51 (ar int.) \\
\hline Ciclohexano & $\mathrm{X}$ & \\
\hline 1,3 dimetil pentano & $\mathrm{X}$ & $\mathrm{X}$ \\
\hline Heptano & $\mathrm{X}$ & $\mathrm{X}$ \\
\hline Metil ciclohexano & $\mathrm{X}$ & $\mathrm{X}$ \\
\hline $\mathbf{2}$ metil heptano & $\mathrm{X}$ & $\mathrm{X}$ \\
\hline Etil benzeno & $\mathrm{X}$ & $\mathrm{X}$ \\
\hline o-xileno & $\mathrm{X}$ & $\mathrm{X}$ \\
\hline Octano & $\mathrm{X}$ & \\
\hline Nonano & $\mathrm{X}$ & \\
\hline 1,2,3 trimetil benzeno & $\mathrm{X}$ & $\mathrm{X}$ \\
\hline 1,3,5 trimetil benzeno & $\mathrm{X}$ & \\
\hline p-xileno & $\mathrm{X}$ & \\
\hline Decano & $\mathrm{X}$ & \\
\hline Undecano & $\mathrm{X}$ & \\
\hline Dodecano & & \\
\hline
\end{tabular}

Todas as substâncias detectadas no ar interno tinham como fonte o ar externo.

Tabela 56- Comparação entre as amostras 52, 53 e 54 quanto as substâncias encontradas através das análises qualitativas pelo modo SCAN

\begin{tabular}{l|c|c|c}
\hline \multicolumn{1}{c|}{ SUBSTANCIAS } & $\begin{array}{c}\text { Amostra 52 } \\
\text { (ar ext.) }\end{array}$ & $\begin{array}{c}\text { Amostra 53 } \\
\text { (ar int.) }\end{array}$ & $\begin{array}{c}\text { Amostra 54 } \\
\text { (ar int.) }\end{array}$ \\
\hline Heptano & $\mathrm{X}$ & $\mathrm{X}$ & $\mathrm{X}$ \\
\hline Octano & $\mathrm{X}$ & $\mathrm{X}$ & $\mathrm{X}$ \\
\hline o-xileno & $\mathrm{X}$ & $\mathrm{X}$ & $\mathrm{X}$ \\
\hline m-xileno & $\mathrm{X}$ & $\mathrm{X}$ & $\mathrm{X}$ \\
\hline p-xileno & $\mathrm{X}$ & $\mathrm{X}$ & $\mathrm{X}$ \\
\hline Etil benzeno & $\mathrm{X}$ & $\mathrm{X}$ & $\mathrm{X}$ \\
\hline 1,3,5 trimetil benzeno & $\mathrm{X}$ & & $\mathrm{X}$ \\
\hline Ciclohexano & & & $\mathrm{X}$ \\
\hline Nonano & & & $\mathrm{X}$ \\
\hline 2 metil heptano & & & $\mathrm{X}$ \\
\hline 1,2 dimetil pentano & & & $\mathrm{X}$ \\
\hline 1 cloro propeno 1 & & & $\mathrm{X}$ \\
\hline 1,3 dicloro propano & & & \\
\hline 2 butoxi etanol & & & \\
\hline
\end{tabular}


O nonano pode advir do carpete do escritório 54 (ECA, 1997). O ciclohexano pode provir dos estofados de vinil dos escritórios (ECA, 1997). O 1,2-dimetil pentano é uma substância característica da composição da gasolina (EMA, 2000). O 1-cloropropano 1 e o 1,3-dicloropropano são utilizados como propelentes em aerossóis (Bloemen e Burn, 1995). O 2 butoxi-etanol não é característico das fontes internas deste escritório, porém pode ser proveniente de fonte externa como a queima incompleta do etanol combustível (EMA, 2000).

\subsubsection{1- Discussão dos resultados qualitativos}

As análises realizadas no espectrômetro de massas pelo modo de varredura de íns (SCAN) demonstraram e confirmaram a afirmação de Brickus e Aquino Neto (1999) que o ar externo influencia diretamente a qualidade do ar interno de escritórios e salas comerciais no Brasil, principalmente devido a má ventilação dos ambientes e inadequada ou mesmo falta de manutenção dos sistemas de condicionamento de ar.

No caso das amostras desta tese, verifica-se que a maioria das substâncias contidas no ar externo estavam também no ar interno, ficando assim difícil afirmar que tal substância no ar interno era certamente de alguma fonte interna. Porém, duas substâncias foram encontradas apenas no ar interno, o D-limoneno e o $\beta$-pineno, substâncias essas características de odorizadores de ambientes e de alguns produtos de limpeza. Todas as substâncias encontradas na análise qualitativa possuem sua correlação na literatura internacional.

Algumas das substâncias encontradas podem possuir mais de uma fonte, seja ela externa ou interna. Tomemos como exemplo o benzeno que, foi analisado quantitativamente, muitos são os estudos que mostram que a fumaça do cigarro possui uma determinada concentração de benzeno (BLOEMEN e BURN,1995), porém também encontramos benzeno no ar externo proveniente da gasolina, da exaustão do escapamento dos motores de veículos que queimam gasolina, do uso de solventes, etc.. No ambiente de escritório, por exemplo, estofados de vinil também podem liberar benzeno e até mesmo algumas resinas de impermeabilização de pisos (ECA, 1997). Mas a emissão destas fontes é pequena como mostrado na Tabela 3, se compararmos com o que vem do ar externo. 
Outro ponto relevante é o processo de adsorção/dessorção provocado pela interação dos compostos orgânicos voláteis e os materiais em geral presentes nos escritórios (ECA, 1997). Os compostos orgânicos voláteis por suas características químicas e físicas possuem a capacidade de quando em contato com determinados materiais como: madeira, papel, pintura de parede, alguns polímeros (plásticos) e outros que possuem a capacidade de adsorver os compostos orgânicos voláteis em suas superfícies e através de forças como de Van der Walls reter estes compostos orgânicos voláteis por determinado tempo que varia conforme a interação entre o material e o composto orgânico volátil. Considerando também que depois de decorrido este tempo o composto orgânico volátil é liberado, ou seja, reemitido ao ar ambiente voltando a contaminá-lo. Este fato pode explicar, por exemplo, a aparição de substâncias que apenas existem no ar exterior (sua fonte principal) e aparecem no ar interior sendo que quando analisamos o ar externo respectivo ao ambiente contaminado em questão não detectamos a substância dando a impressão que existe uma fonte interna para esta substância. Também o efeito concentrador de poluentes pode ser atrelado a este tipo de ocorrência, onde podemos ter a liberação do poluente agregado a algum material apenas horas ou dias depois conforme a situação do ambiente. Por exemplo, a incidência de luz solar dentro do ambiente pode liberar substâncias que estejam adsorvidas a determinados materiais (ECA, 1997).

Portanto neste estudo comparou-se, do ponto de vista qualitativo, as substâncias que ocorreram no ar interno e que não foram encontradas no ar externo.

\section{5- Avaliação estatística das amostras}

Tanto para as análises realizadas em escritórios com condicionador de ar de janela como central as médias das amostras não são significativamente diferentes entre si, a hipótese nula é confirmada. Isto também se aplica às amostras com condicionador de ar tipo SPLIT, porém com a exceção das análises de tolueno com este tipo de condicionador indicando que as médias das amostras são significativamente diferentes entre si. Os picos de concentração em amostras de ar interno contribuíram para o desvio estatístico. 


\section{5- CONCLUSÕES}

As análises quantitativas mostraram a presença de benzeno, tetracloreto de carbono e tolueno e as análises qualitativas mostraram uma gama de substâncias nocivas com origem externa e também interna; de origem interna tem-se especificamente D-limoneno, $\beta$-pineno e diclorobenzeno; para as demais substâncias encontradas no ar dos escritórios, como mostrado na sequêencia de tabelas do item 4.4.2, a afirmação de que sua origem seja exclusivamente interna fica prejudicada, pois também foi verificada a presença destas substâncias no ar externo aos escritórios amostrados.

Foi encontrado benzeno em $76,7 \%$ das amostras; a concentração de benzeno nos escritórios variou de 0,14 a 3,65 ppb em volume. Se compararmos o resultado de pico observado - 3,65 ppb em volume - correspondente a $11,6 \mu \mathrm{g} / \mathrm{m}^{3}$, com a legislação polonesa para o ar de ambientes interiores, citado por Zabiegala e col. (1999) que recomenda a concentração máxima de $10 \mu \mathrm{g} / \mathrm{m}^{3}$ de benzeno, pode-se considerar que os ocupantes dos escritórios amostrados podem estar sujeitos a níveis que afetam sua saúde, tendo em vista principalmente que a fonte de contaminação externa para o benzeno é a exaustão dos escapamentos de automóveis e a evaporação de vapores da gasolina, tomando por base que a área amostrada possui denso tráfego de automóveis e três postos de gasolina nas proximidades (rua da Consolação e Amaral Gurgel). A legislação citada é do Ministério da Saúde e Seguridade Social da Polônia de 12 de março de 1996, a qual foi baseada em estudos sobre emissões de materiais de construção e mobilias em ambientes interiores de fins ocupacionais.

A metodologia alternativa utilizada, baseada nos métodos NIOSH 1003, $1500 \mathrm{e}$ 1501 , mostrou-se eficiente. Conseguiu-se coletar, com o tubo amostrador e vazão especificada pelos métodos citados, quantidades correspondentes a concentrações no nivel de ppb em volume, das substâncias contidas no ar interior dos escritórios e quantificar substâncias como clorofórmio, tetracloreto de carbono, benzeno e tolueno. Os testes de limite de detecção, precisão e recuperação do método 
analítico, avaliação do adsorvente e do dessorvedor, bem como validação do método de coleta, mostraram resultados que, comparados com os critérios do NIOSH, podemos considerar a alternativa analítica aplicada válida para as amostras analisadas.

Pelas concentraç̃oes médias verificadas nas análises das amostras dos escritórios notamos que os resultados para benzeno e tolueno não diferem da faixa existente na literatura internacional como apresentados por Cheng (2000), Srivastava (2000), Fantuzzi (1996), McClenny (1998), Perry (1997) e Zabiegala (1999).

O tetracloreto de carbono foi detectado com baixa freqüência nos interiores amostrados e teve por origem o ar externo; o clorofórmio ficou abaixo do limite de detecção do método, podendo-se concluir que estas duas substâncias não ofereciam riscos à saúde dos ocupantes dos ambientes amostrados.

Quanto às concentrações de tolueno, que foi encontrado e quantificado em $100 \%$ das amostras, tanto no ar dos interiores como no ar externo, o valor médio obtido nas amostras dos escritórios foi $60,9 \mu \mathrm{g} / \mathrm{m}^{3}$ de tolueno, se compararmos com a recomendação da legislação polonesa para ar de interiores, a qual indica um valor máximo de $200 \mu \mathrm{g} / \mathrm{m}^{3}$ para tolueno, então pode-se considerar adequado este nível de tolueno para estes escritórios, porém se considerados os resultados pontuais, houve $20 \%$ das amostras dos escritórios com níveis acima de $100 \mu \mathrm{g} / \mathrm{m}^{3}$ de tolueno no ar e em uma amostra foram encontrados $185 \mu \mathrm{g} / \mathrm{m}^{3}$ de tolueno no ar. Portanto, se for tomada por referência a legislação polonesa, estar-se-ia com resultados nas amostras de escritórios do centro de São Paulo próximas de níveis que poderiam afetar a saúde de seus ocupantes.

Os compostos orgânicos voláteis encontrados no ar interior dos escritórios amostrados tiveram como fonte principal de poluentes $o$ ar externo.

$\mathrm{Na}$ comparação entre os resultados obtidos dos diferentes tipos de condicionadores de ar verificou-se o efeito concentrador de substâncias em escritórios com sistemas de ar condicionado dos tipos de janela e SPLIT devido a 
falta ou pouca renovação de ar. No caso de escritórios com sistema de ar condicionado central, notou-se que a renovação de ar proporcionada pelo sistema ajuda na diminuição da concentração dos poluentes no ar interno principalmente com manutenção adequada dos filtros que mesmo não sendo próprios para reter compostos orgânicos voláteis, $o$ fazem por via indireta.

Existe a necessidade de monitoramento dos compostos orgânicos voláteis para evitar/amenizar os sintomas relacionados com a Síndrome do Edifício Doente e Doença Relacionada com o Edificio, pois como verificou-se na literatura internacional e citamos em capítulos anteriores que existem problemas causados à saúde dos trabalhadores que possuem correlação com várias substâncias encontradas no ar de interiores, as quais também foram encontradas nas amostras deste estudo.

Portanto, verificou-se a existência de compostos orgânicos voláteis nocivos a saúde humana no ar de interiores climatizados com ausência de tabagismo caracterizando assim a necessidade do controle destas substâncias no ar ambiental de interiores climatizados podendo ser utilizado para tanto o método o apresentado nesta tese. 


\section{6- RECOMENDAÇÕES}

Estudar a viabilidade de inserir na Resolução $n^{\circ} 9$ da Agência Nacional de Vigilância Sanitária como Norma Técnica a metodologia utilizada nesta tese a fim de efetivar o controle de compostos orgânicos voláteis no ar de ambientes climatizados.

Enfatizar a necessidade de realização de manutenção periódica nos sistemas de condicionamento de ar com intuito, dentre outros, de evitar o arraste mecânico de compostos orgânicos voláteis que possam ter sido retidos nos filtros do sistema.

Proporcionar aos ambientes interiores climatizados taxa de ventilação conforme preconizado na Resolução ANVISA nº 9/2003 da fim de evitar o efeito concentrador de substâncias nocivas no ar ambiental destes locais como ficou caracterizado nos resultados obtidos principalmente nos escritórios com baixa ventilação.

Estudar os níveis de emissão de Compostos Orgânicos Voláteis dos materiais característicos de escritórios que são fabricados no Brasil com matérias primas nacionais, pois as bibliografias disponiveis sobre emissão de materiais indicam valores referentes em geral à Europa ou Estados Unidos. Isto também se aplica aos materiais de construção civil. 


\section{7- BIBLIOGRAFIA}

American Standard Test Method. ASTM D 3686 - 95: standard practice for analysis of organic compounds vapors collected activated charcoal tube adsorption method. USA, 1995.

American Standard Test Method. ASTM D 3687 - 95: standard practice for sampling atmospheres to collect organic compounds vapors (activated charcoal tube adsorption method). USA, 1995.

American Standard Test Method. ASTM D 1357 - 95: standard practice for planning the sampling of the ambient atmosphere. USA, 1995.

American Standard Test Method. ASTM D 5466 - 95: standard test method for determination of volatile organic chemicals in atmospheres (canister sampling methodology). USA,1995.

American Standard Test Method. ASTM D1356 - 97: standard terminology relating to sampling and analysis of atmospheres. USA, 1997.

American Standard Test Method. ASTM E 260 -96: standard practice for packed column gas chromatography. USA,1996.

American Standard Test Method. ASTM E 355 - 96: standard practice for gas chromatography terms and relationships. USA,1996.

Associação Brasileira de Normas Técnicas. NBR 10562: calibração de vazão, pelo método da bolha de sabão, de bombas de baixa vazão utilizadas na avaliação de agentes químicos no ar. Rio de Janeiro, 1988. 
Assunção JV. Importância da ventilação no controle da síndrome dos edifícios doentes. IV Encontro Brasileiro de Higienistas Ocupacionais. São Paulo, 19 a 22 de agosto de 1997. Promovido pela ABHO - Associação Brasileira de Higienistas Ocupacionais.

Bergerow J, Jermann E, Keles T, Koch T e Dunemann L. Screening method for the determination of 28 volatile organic compounds in indoor and outdoor air at environmental concentrations using dual-column capillary gas chromatografy with tandem electron - capture - flame ionization. J of Chrom A; 1996

Bernardo C e Favoreto COR. Coletânea de Legislação Ambiental Básica Federal. Rio de Janeiro: Editora Lumen Juris; 2001.

Bloemen HJTh e Burn J. Chemistry and analysis of volatile organic compounds in the environment. USA: Blackie Academic \& Professional; 1995.

Boubel RW, Fox DL, Turner DB e Stern AC. Fundamentals of Air Pollution. $3^{\text {th }}$ ed. Academic Press; 1994. Indoor air quality; p. 383-394.

Brancaleoni E, Scovaventi M, Frattoni M, Mabilia R e Ciccioli P. Novel family of multi-layer cartridges filled with a new carbon adsorbent for the quantitative determination of volatile organic compounds in the atmosphere. $\mathbf{J}$ of Chrom A, 845, pp 317-328, 1999.

Brickus LSR, Aquino Neto FR. A qualidade de interiores e a química. Química Nova $1999 ; 22: 10-46$.

Cardoso LMN. Avaliação de metodologia de coleta e análise solventes/misturas de solventes no ar em ambiente de trabalho:"metanol em mistura MEG"(metanol 33\%,etanol 60\% e gasolina7\%). São Paulo; 1995. [Tese de Doutorado - Instituto de Química da USP].

CETESB. Relatório de qualidade do ar no Estado de São Paulo 2001. São Paulo: Cetesb, 2002. 
Cheng, LS, Ming LW. Indoor Air Quality Investigation at Homes, Commercial Offices, Schools, Shopping Malls and Restaurants in Hong Kong. Proceedings of AWMA's 93 ${ }^{\text {rd }}$ Annual Conference. 2000, june 18-22. Salt Lake City, Utah.

Collins HC, Braga LG, Bonato PS. Introdução a Métodos Cromatográficos. $4^{a}$ edição: Editora da Unicamp; Campinas, São Paulo 1990.

Colón M, Pleil JD, Hartlage TA, Guardani ML e Martins MH. Survey of volatile organic compounds associated with automotive emissions in the urban airshed of São Paulo, Brazil. Atm Environ 2001; 35: 4017-4031.

Cralley LV, Cralley LJ e Cooper WC. Health and Safety Beyond the Worplace. John Wiley \& Sons: 1990. Indoor air pollution; p. 81-119.

Engine Manufacturers Association. World - Wide fuel charter. Report. USA. 2000.

European Collaborative Action. Indoor air quality \& its impact no man - Evaluation of VOC emissions from buildings products. Report $\mathbf{n}^{\circ} \mathbf{1 8}$. Luxembourg. 1997.

Fantuzzi G, Aggazzotti G, Righi E, Cavazzuti L, Predieri G e Franceschelli A. Indoor air quality in the university libraries of Modena (Italy). The Science of the Total Environmental 193. 1996.

Guo Z, Sparks LE, Tichenor BA, Chang JCS. Predicting the emissions of individual VOC from petroleum-based indoor coatings. Atm Environ 1998. Vol. 32, No. 2, p. 231-237.

Guo Z, Chang JCS, Sparks LE, Fortmann RC. Estimation of the rate of VOC emissions from solvent-based indoor coating materials based on product formulation. Atm Environ 1999. Vol. 33, p. 1205-1215. 
Helmig D, Greenberg J. Artifact formation from the use of potassium-iodide-based ozone traps during atmospheric sampling of trace organic gases. Journal of Hight Resolution Chromatography 1995. vol.18.

Helmig D, Greenberg JP. Automated in situ gas chromatographic-mass spectrometric analysis of ppt level volatile organic trace gases using multistage solid-adsorbent trapping. J of Chrom A 1994. 677, p. 123-132.

Hoffman T. Adsorptive preconcentration technique including oxidant scavenging for the measurement of reative natural hydrocarbons in ambient air. $\mathbf{J}$ of Anal Chem 1995. 351;p. 41-47.

Kahl J., Siemens DH, Aerts RJ, Gäbler R, Kühnemann F, Preston CA, Baldwin IT. Herbivore-induced ethylene suppresses a direct defense but not a putative indirect defense against an adapted herbivore. Planta Journal 1999. 425/0167.

Knudsen HN, Kjaer UD, Nielsen PA e Wolkoff P. Sensory and Chemical characterization of $\mathrm{VOC}$ emissions from building products: impact of concentration and air velocity. Atm Environ 1999. Vol. 33, p. 1217-1230.

Lamb SI, Petrowski C, Kaplan IR e Simoneit BRT. Organic compounds in urban atmospheres: a review of distribution, collection and analysis. Journal of the Air Pollution Control Association 1980, p.1098-1107.

McClenny WA, Colon M. Measurement of volatile organic compounds by the US Environmental Protection Agency Compendium Method TO-17 - Evaluation of performance criteria. J of Chrom A 1998. 813: p.101-111.

Meininghaus R, Salthammer $\mathrm{T}$ e Knöppel $\mathrm{H}$. Interation of volatile organic compounds with indoor materials - a small - scale screening method. Atm Environ 1999.Vol. 33, p. 2395-2401.

MERCK. Index Merck. Twelfth edition: USA,1996. 
Miguel HA, Aquino Neto FR, Cardoso JN, Vasconcellos PC, Pereira AS, Marquez KSG. Characterization of indoor air quality in the cities of São Paulo and Rio de Janeiro - Brazil. Environ Sc Tech 1995.29:p. 338-345.

National Institute for Occupational Safety and Health - NIOSH. Pocket Guide to Chcmical Hazards. USA,2001.

National Institute for Occupational Safety and Health - NIOSH. Manual of Analytical Methods - Hydrocarbons, Halogenated, Method 1003. Fourth edition: USA, 1994a.

National Institute for Occupational Safety and Health - NIOSH. Manual of Analytical Methods - Hydrocarbons, $36-126^{\circ} \mathrm{C}$ BP Method 1500. Fourth edition: USA, $1994 b$.

National Institute for Occupational Safety and Health - NIOSH. Manual of Analytical Methods - Hydrocarbons, Aromatic, Method 1501. Fourth edition: USA, 1994c.

National Institute for Occupational Safety and Health - NIOSH. Manual of Analytical Methods - Development and Evaluation of Methods. USA, 1998.

Occupational Safety and Health Administration - OSHA. Evaluation Guidelines for Air Sampling Methods Utilizing Chromatographic Analysis. USA, 1999.

Occupational Safety and Health Administration - OSHA. Federal Register Indoor Air Quality. USA, 1994.

Occupational Safety and Health Administration - OSHA. Method 07 - Organic Vapors. USA, 2000. 
Occupational Safety and Health Administration - OSHA. Method 12 - Organic Method - Benzene. USA, 1980.

Occupational Safety and Health Administration - OSHA. Method 111 - Organic Method - Toluene. USA, 1998.

Occupational Safety and Health Administration - OSHA. Method 05 - Organic Vapors - Chloroform. USA, 1979.

Occupational Safety and Health Administration - OSHA. Sampling and analytical for benzene monitoring and measurement procedures - 1910.1028AppD.

Disponível em

<URL:http://www.osha-slc.gov/OshStd_data/1910_1028_APP_D.html

Occupational Safety and Health Administration - OSHA. Centers for Disease Control and Prevention. USA, 1996.

Oga S. Fundamentos de toxicologia. Editora Atheneu; São Paulo,1996.

Pelizzari ED, Krost KJ. Chemical transformations during ambient air sampling for organic vapors. Anal Chem 1984.Vol 56, p.1813-1819.

Perry R, Baek S e Kim Y. Indoor air quality in homes, offices and restaurants in Korean urban areas - indoor/outdoor relationships. Atm Environ 1997. Vol. 31, No. 4: p.529-544.

Pereira FAC. Estudo exploratório da influência da poluição do ar na incidência de câncer nos distritos do município de São Paulo. São Paulo; 2000. [Dissertação de Mestrado - Faculdade de Saúde Pública da USP]. 
Pesquero CR. Avaliação ambiental de compostos orgânicos aromáticos presentes em atmosferas industriais. São Paulo; 2001. [Tese de Doutorado - Instituto de Química da USP].

Petillo VLS. Avaliação de desinfetantes de uso geral quanto à emissão de formaldeído. São Paulo; 2002. [Tese de Doutorado - Faculdade de Saúde Pública da USP].

Probert S.M., Mak A .K., Zazulak E.P. e Fok N.M. Indoor Air Quality in a Canadian Elementary School. Proceedings of AWMA's $93^{\text {rd }}$ Annual Conference. 2000, june 18-22. Salt Lake City, Utah.

Rothweiler H, Wäger PA, Schlatter C. Comparison of Tenax TA and carbotrap for sampling and analysis of volatile organic compounds in air. Atm Environ 1991. Vol.25B, $\mathrm{n}^{\circ} 2: \mathrm{p} .231-235$.

Schuh $\mathrm{G}$ e col. Emissions of volatile organic compounds from Sunflower and Beech: dependence on temperature and light intensity. J of Atm Chem 1997. 27: p. 291318.

Sigma-Aldrich Company. Supelco - Air Methods Guide. $2^{\text {nd }}$ edition. 1999. Disponivel em URL:http://www.supelco.com

Srivastava PK, Pandit GG, Sharma S e Mohan Rao AM. Volatile Oragnic Compounds in indoor environments in Mumbai - India. The Science of the Total Environmental 2000. 255: p. 161-168.

United States Department of Health, Education and Welfare (USDHEW). Air quality criteria for photochemical oxidants. National Air Pollution Control Administration. Report. Washington,DC. 1970.(USDHEW AP-63) 
United States Environmental Protection Agency. Compendium Method TO-14A, Determination of Volatile Organic Compounds in Ambient Air Using Specially Prepared Canisters with subsequent Analysis by Gas Chromatography. Second edition, Cincinnati, USA, 1999.

United States Environmental Protection Agency. Compendium Method TO-15, Determination of Volatile Organic Compounds in Air Collected in Specially Prepared Canisters with subsequent Analysis by Gas Chromatography/Mass Spectrometry. Second edition, Cincinnati, USA, 1999.

United States Environmental Protection Agency. Compendium Method TO-17, Determination of Volatile Organic Compounds in Ambient Air Using Active Sampling Onto Sorbent Tubes. Second edition, Cincinnati, USA 1999.

United States Environmental Protection Agency. Indoor Air Pollution - Na Introduction for Health Professionals. Publication. USA 1994. (US Government Printing Office Publication n ${ }^{\circ}$ 1994-523-217/81322).

United States Environmental Protection Agency. Method TO-2 - Method for the determination of volatile compounds in ambient air by carbon molecular sieve adsorption and gas chromatography/mass spectrometry (GC/MS). USA 1984.

United States Environmental Protection Agency. The inside Story - A guide to indoor air quality. Office of Radiation and Indoor Air. Document. USA 1995. (Document EPA 402-K-93-007).

United States Environmental Protection Agency. Indoor Air Quality and Work Environment Survey: EPA Headquarters Buildings. USEPA. Vol. 1. USA, 1989.

Weiss G. Hazardous chemicals data book. Second edition: Noyes Data corporation; USA,1986. 
Wolkoff P, Schineider T, Kildesø J, Degerth R, Jaroszewski M, Schunk H. Risk in cleaning: chemical and physical exposure. The Science of the Total Environmental 1998. 215:p. 135-156.

Wolkoff P, Schineider T, Kildesø J, Degerth R, Jaroszewski M, Schunk H. Risk in cleaning: chemical and physical exposure. The Science of the Total Environmental 1998. 215:p. 135-156.

Wolkoff P. How to measure and evaluate volatile organic compound emissions from building products - A perspective. The Science of the Total Environmental 1999. 227: p. 197-213.

Yu C, Crump D. A review of the Emission of VOC from Polymeric Materials used in Buildings. Building and Environment 1998. Vol. 33, No. 6: p.357-374.

World Health Organization. Air Quality Guidelines. Environmental health information. 1999. Disponível em

<URL:http://www.who.int./environmental_information/air/guidelines/AQGUIDEPR EF.htm

World Health Organization. European Commission, Joint Research CentreEnviroment Institute, Evaluation of VOC Emissions from Building Products, Solid Flooring Materials. Report. Luxemburgo,1997.(Report $\left.n^{\circ} 18\right)$.

World Health Organization. Indoor air quality research. Stockholm;1984.(EURO Reports and studies 103).

World Health Organization. Indoor air quality: organic pollutants. Berlin;1987.(EURO Reports and studies 111).

World Health Organization. Indoor Air Quality: Radon and Formaldehide. Report. Copenhagen,1986.(Report n $\left.{ }^{\circ} 13\right)$. 
World Health Organization. Air quality guidelines. 1999. Disponivel em <URLhttp://www.who.int/environmental_information/Air/Guidelines/Chapter4.htm

Zabiegala B, Namiešnik J, Przyk E e Przyjasny A. Changes in concentration levels of select VOC in newly erected and remodelled buildings in Gdansk. Chemosphere 1999. Vol. 39, No.12: p.2035-2046.

Zhu J, Zhang J, Shaw C. Chemical composition analysis and its application in estimation of VOC emission rates from hydrocarbon solvent-based indoor materials. Chemosphere 1999. Vol. 39, No.14: p.2535-2547. 
Anexo 1-

Resolução n ${ }^{\circ} 9$ da Agência Nacional de Vigilância Sanitária 
O Diretor da Diretoria Colegiada da Agência Nacional de Vigilância Sanitária, no uso da atribuição que Ihe confere a Portaria $n^{\circ} 570$, do Diretor Presidente, de 3 de outubro de 2002;

considerando 0 $3^{\circ}$, do art. 111 do Regimento Interno aprovado pela Portaria.$^{\circ} 593$, de 25 de agosto de 2000 , republicada no DOU de 22 de dezembro de 2000 ,

considerando a necessidade de revisar e atualizar a REIANVISA $n^{\circ} 176$, de 24 de outubro de 2000 , sobre Padrões Referenciais de Qualidade do Ar Interior em Ambientes Climatizados Artificialmente de Uso Público e Coletivo, frente ao conhecimento e a experiência adquiridos no pais nos dois primeiros anos de sua vigência;

considerando o interesse sanitário na divulgação do assunto;

considerando a preocupação com a saúde, a segurança, o bem-estar e o conforto dos ocupantes dos ambientes climatizados;

considerando o atual estágio de conhecimento da comunidade cientifica intemacional, na área de qualidade do ar ambiental interior, que estabelece padrões referenciais e/ou orientaçōes para esse controle;

considerando o disposto no art. $2^{\circ}$ da Portaria GMMS n. ${ }^{\circ} 3.523$, de 28 de agosto de 1998;

considerando que a matéria foi submetida à apreciação da Diretoria Colegiada que a aprovou em reunião realizada em 15 de janeiro de 2003 , resolve:

Art $1^{\circ}$ Determinar a publicação de Orientação Técnica elaborada por Grupo Técnico Assessor, sobre Padrōes Referenciais de Qualidade do Ar Interior, em ambientes climatizados artificiamente de uso público e coletivo, em anexo.

Art. $2^{\circ}$ Esta Resolução entra em vigor na data de sua publicação.

\section{CLÁUDIO MAIEROVITCH PESSANHA HENRIQUES}

ANEXO

\section{ORIENTAÇÃO TÉCNICA ELABORADA POR GRUPO TÉCNICO ASSESSOR SOBRE PADRÕES REFERENCAIS DE QUALIDADE DO AR INTERIOR EM AMBIENTES CLIMATIZADOS ARTIFICIALMENTE DE USO PÚBLICO E COLETIVO}

\section{1-HISTÓRICO}

O Grupo Técnico Assessor de estudos sobre Padrões Referenciais de Qualidade do Ar Interior em ambientes climatizados artificialmente de uso público e coletivo, foi constituído pela Agência Nacional de Vigilância Sanitária ANVISA, no âmbito da Gerência Geral de Serviços da Diretoria de Serviços e Correlatos e instituído por membros das seguintes instituiçōes:

Sociedade Brasileira de Meio Ambiente e de Qualidade do Ar de Interiores/BRASINDOOR, Laboratório Noel Nutels Instituto de Química da UFRJ, Ministério do Meio Ambiente, Faculdade de Medicina da USP, Organização Panamericana de Saúde/OPAS, Fundação Oswaldo Cruz/FIOCRUZ, Fundação Jorge Duprat Figueiredo de Segurança e Medicina do Trabalho - FUNDACENTRO/MTb, Instituto Nacional de Metrologia Normalização e Qualidade Industrial/INMETRO, Associação Paulista de Estudos e Controle de Infecção Hospitalar/APECIH e, Serviço de Vigilância Sanitária do Ministério da Saúde/RJ, Instituto de Ciências Biomédicas-1CB/USP e Agência Nacional de Vigilância Sanitária.

Reuniu-se na cidade de Brasilia/DF, durante o ano de 1999 e primeiro semestre de 2000, tendo como metas:

1. estabelecer critérios que informem a população sobre a qualidade do ar interior em ambientes climatizados artificialmente de uso público e coletivo, cujo desequilibrio poderá causar agravos a saúde dos seus ocupantes;

2. instrumentalizar as equipes profissionais envolvidas no controle de qualidade do ar interior, no planejamento, elaboração, análise e execução de projetos físicos e nas ações de inspeção de ambientes climatizados artificialmente de uso público e coletivo.

Reuniurse na cidade de Brasilia/DF, durante o ano de 2002, tendo como metas:

1. Promover processo de revisão na Resolução ANVISA -RE 176/00

2. Atualiza-la frente a realidade do conhecimento no pais.

3. Disponibilizar informações sobre o conhecimento e a experiência adquirida nos dois primeiros anos de vigência da RE 176. 


\section{$\|$ - ABRANGÊNCIA}

O Grupo Técnico Assessor elaborou a seguinte Orientação Técnica sobre Padrões Referenciais de Qualidade do Ar Interior em ambientes climatizados artificialmente de uso público e coletivo, no que diz respeito a definição de valores máximos recomendáveis para contaminação biológica, química e parâmetros físicos do ar interior, a identificação das tontes poluentes de natureza biológica, quimica e física, métodos analiticos ( Normas Técnicas 001, 002,003 e 004 ) e as recomendações para controle (Quadros le II ).

Recomendou que os padrōes referenciais adotadas por esta Orientação Técnica sejam aplicados aos ambientes climatizados de uso público e coletivo já existentes e aqueles a serem instalados. Para os ambientes climatizados de uso restrito, com exigências de filtros absolutos ou instalaçōes especiais, tais como os que atendem a processos produtivos, instalações hospitalares e outros, sejam aplicadas as normas e regulamentos especificos.

\section{III-DEFINIÇÕES}

Para fins desta Orientação Técnica sāo adotadas as seguintes definiçōes, complementares às adotadas na Portaria GMMS n. ${ }^{\circ}$ 3.523/98:

a) Aerodispersóides sistema disperso; em um meio gasoso; composto de particulas sólidas elou liquidas. O mesmo que aerosol ou aerossol.

b) ambiente aceitávet ambientes livres de contaminantes em concentrações potencialmente perigosas à saủde dos ocupantes ou que apresentem um minimo de $80 \%$ dos ocupantes destes ambientes sem queixas ou sintomatologia de desconforto 2

c) ambientes climatizados: são os espaços fisicamente determinados e caracterizados por dimensões e instalações próprias, submetidos ao processo de climatização, através de equipamentos.

d) ambiente de uso público e coletivo: espaço fisicamente determinado e aberto a utilização de muitas pessoas.

e) ar condicionado: é o processo de tratamento do ar, destinado a manter os requerimentos de Qualidade do Ar Interior do espaço condicionado, controlando variáveis como a temperatura, umidade, velocidade, material particulado, particulas biológicas e teor de dióxido de carbono $\left(\mathrm{CO}_{2}\right)$.

f) Padräo Referencial de Qualidade do Ar Interior: marcador qualitativo e quantitativo de qualidade do ar ambiental interior, utilizado como sentinela para determinar a necessidade da busca das fontes poluentes ou das intervenções ambientais

g) Qualidade do Ar Ambiental Interior: Condição do ar ambiental de interior, resultante do processo de ocupação de um ambiente fechado com ou sem climatização artificial.

h) Valor Máximo Recomendável Valor limite recomendável que separa as condições de ausência e de presença do risco de agressão à saúde humana.

\section{N-PADRŌES REFERENCIAIS}

Recomenda os seguintes Padröes Referenciais de Qualidade do Ar Interior em ambientes climatizados de uso público e coletivo.

1 - O Valor Máximo Recomendável - VMR, para contaminaçäo microbiológica deve ser $\leq 750 \mathrm{ufclm}^{3}$ de fungos, para a relação $I / E \leq 1,5$, onde I é a quantidade de fungos no ambiente interior e $E$ é a quantidade de fungos no ambiente exterior.

NOTA: A relação I/E é exigida como forma de avaliação frente ao conceito de normalidade, representado pelo meio ambiente exterior e a tendência epidemiológica de amplificação dos poluentes nos ambientes fechados.

1.1 - Quando o VMR for ultrapassado ou a relação VIE for > 1,5, é necessário fazer um dagnóstico de fontes poluentes para uma intervenção corretiva.

1.2 - É inaceitável a presença de fungos patogênicos e toxigênicos.

2- Os Valores Máximos Recomendáveis para contaminaçāo quimica são:

2.1 - $\leq 1000 \mathrm{ppm}$ de dióxido de carbono $-\left(\mathrm{CO}_{2}\right)$, como indicador de renovação de ar extemo, recomendado para conforto e bem-estar ${ }^{2}$

$2.2-\leq 80 \mu \mathrm{gm} \mathrm{m}^{3}$ de aerodispersóides totais no ar, como indicador do grau de pureza do ar e limpeza do ambiente climatizado ${ }^{4}$

NOTA: Pela falta de dados epidemiológicos brasileiros é mantida a recomendação como indicador de renovação do ar o valor $=1000 \mathrm{ppm}$ de Dióxido de carbono $-\mathrm{CO}_{2}$

3 - Os valores recomendáveis para os parâmetros fisicos de temperatura, umidade, velocidade e taxa de renovação do ar e de grau de pureza do ar, ceverão estar de acordo com a NBR 6401 - Instalações Centrais de Ar Condicionado para Conforto-Parâmetros Básicos de Projeto da ABNT - Associação Brasileira de Normas Técnicas ${ }^{5}$.

3.1 - a faixa recomendável de operação das Temperaturas de Bulbo Seco, nas condições intemas para verão, deverá variar de $23^{\circ} \mathrm{C}$ a $26^{\circ} \mathrm{C}$, com exceção de ambientes de arte que deverão operar entre $21^{\circ} \mathrm{C}$ e $23^{\circ} \mathrm{C}$. A faixa máxima de operaçäo deverá variar de $26,5^{\circ} \mathrm{C}$ a $27^{\circ} \mathrm{C}$, com exceção das áreas de acesso que poderão operar até $28^{\circ} \mathrm{C}$. A seleção da faixa depende da finalidade e do local da instalação. Para condições internas para inverno, a faixa recomendável de operaçäo deverá variar de $20^{\circ} \mathrm{C}$ a $22^{\circ} \mathrm{C}$. 
3.2 - a faixa recomendável de operaçäo da Umidade Relativa, nas condições internas para verão, deverá variar de $40 \%$ a $65 \%$, com exceção de ambientes de arte que deverão operar entre $40 \%$ e $55 \%$ durante todo o ano. O valor máximo de operaçāo deverá ser de $65 \%$, com exceção das áreas de acesso que poderão operar atè $70 \%$. A seleção da faixa depende da finalidade e do local da instalação. Para condições internas para inverno, a faixa recomendável de operação deverá variar de $35 \%$ a $65 \%$.

3.3 - o Valor Máximo Recomendável - VMR de operação da Velocidade do Ar, no nivel de 1,5m do piso, na região de influência da distribuição do ar é de menos $0,25 \mathrm{~m} / \mathrm{s}$.

3.4 - a Taxa de Renovação do Ar adequada de ambientes climatizados será, no mínimo, de $27 \mathrm{~m}^{3} / \mathrm{hora} / \mathrm{pessoa}$, exceto no caso especifico de ambientes com alta rotatividade de pessoas. Nestes casos a Taxa de Renovação do Ar mínima será de $17 \mathrm{~m}^{3} /$ hora/pessoa, não sendo admitido em qualquer situação que os ambientes possuam uma concentração de $\mathrm{CO}_{2}$, maior ou igual a estabelecida em IV-2.1, desta Orientação Técnica.

3.5 - a utilização de filtros de classe G1 é obrigatória na captação de ar exterior. O Grau de Pureza do Ar nos ambientes climatizados será obtido utilizando-se, no minimo, filtros de classe $G 3$ nos condicionadores de sistemas centrais, minimizando o acúmulo de sujidades nos dutos, assim como reduzindo os níveis de material particulado no ar insuflado ${ }^{2}$.

Os padrōes referenciais adotados complementam as medidas básicas definidas na Portaria GM/MS n. $3.523 / 98$, de 28 de agosto de 1998, para efeito de reconhecimento, avaliação e controle da Qualidade do Ar Interior nos ambientes climatizados. Deste modo poderão subsidiar as decisões do responsável técnico pelo gerenciamento do sistema de climatização, quanto a definição de periodicidade dos procedimentos de limpeza e manutenção dos componentes do sistema, desde que asseguradas as freqüências minimas para os seguintes componentes, considerados como reservatórios, amplificadores e disseminadores de poluentes.

\begin{tabular}{|c|c|}
\hline Componente & Periodicidade \\
\hline Tomada de ar externo & $\begin{array}{l}\text { Limpeza mensal ou quando } \\
\text { descartável atė sua obliteração } \\
\text { (máximo } 3 \text { meses) }\end{array}$ \\
\hline Unidades filtrantes & $\begin{array}{l}\text { Limpeza mensal ou quando } \\
\text { descartável até sua obliteração } \\
\text { (máximo } 3 \text { meses) }\end{array}$ \\
\hline Bandeja de condensado & Mensal $^{*}$ \\
\hline Serpentina de aquecimento & $\begin{array}{c}\text { Desencrustação semestral e limpeza } \\
\text { trimestral }\end{array}$ \\
\hline Serpentina de resfriamento & $\begin{array}{c}\text { Desencrustação semestral e limpeza } \\
\text { trimestral }\end{array}$ \\
\hline $\begin{array}{l}\text { Umidificador } \\
\text { Ventilador } \\
\text { Plenum de mistura/casa de } \\
\text { máquinas }\end{array}$ & $\begin{array}{c}\text { Desencrustação semestral e limpeza } \\
\text { trimestral } \\
\text { Semestral } \\
\text { Mensal }\end{array}$ \\
\hline
\end{tabular}

* Excetuando na vigência de tratamento quimico contínuo que passa a respeitar a periodicidade indicada pelo fabricante do produto utilizado.

\section{V-FONTES POLUENTES}

Recomenda que sejam adotadas para fins de pesquisa e com o propósito de levantar dados sobre a realidade brasileira, assim como para avaliação e correção das situações encontradas, as possiveis fontes de poluentes informadas nos Quadros l ell.

\section{QUADROI}

Possiveis fontes de poluentes biológicos ${ }^{6}$

\begin{tabular}{|c|c|c|}
\hline $\begin{array}{l}\text { Agentes } \\
\text { biológicos }\end{array}$ & $\begin{array}{l}\text { Principais fontes em } \\
\text { ambientes interiores }\end{array}$ & $\begin{array}{l}\text { Principais Medidas de } \\
\text { correção em ambientes } \\
\text { interiores }\end{array}$ \\
\hline Bactérias & $\begin{array}{l}\text { Reservatónios com água } \\
\text { estagnada, } \\
\text { torres de resfriamento, } \\
\text { bandejas de condensado, } \\
\text { desumificadores, } \\
\text { umidificadores, serpentinas } \\
\text { de condicionadores de ar e } \\
\text { superficies úmidas e } \\
\text { quentes. }\end{array}$ & $\begin{array}{l}\text { Realizar a limpeza e a } \\
\text { conservaçäo das torres de } \\
\text { resfriamento; higienizar os } \\
\text { reservatórios e bandejas de } \\
\text { condensado ou manter } \\
\text { tratamento continuo para } \\
\text { eliminar as fontes; eliminar } \\
\text { as infiltraçöes; higienizar as } \\
\text { superficies. }\end{array}$ \\
\hline
\end{tabular}




\begin{tabular}{|c|c|c|}
\hline Fungos & \begin{tabular}{lrr} 
Ambientes & \multicolumn{1}{r}{ úmidos } \\
demais & fontes & de \\
multiplicação füngica, como \\
materiais r porosos \\
orgânicos úmidos, forros, \\
paredes e isolamentos \\
úmidos; ar extemo, interior \\
de condicionadores e dutos \\
sem manutenção, vasos de \\
terra com plantas.
\end{tabular} & 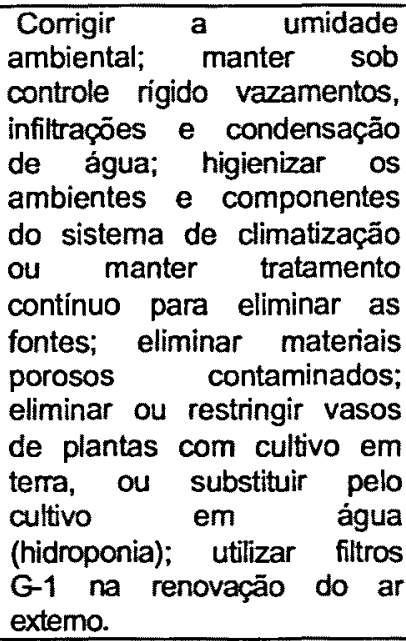 \\
\hline Protozoários & $\begin{array}{lrr}\text { Reservatórios } & \text { de } & \text { água } \\
\text { contaminada, bandejas } & \text { e } \\
\text { umidificadores } & & \text { de } \\
\text { condicionadores } & & \text { sem } \\
\text { manutenção. } & & \\
\end{array}$ & $\begin{array}{l}\text { Higienizar o reservatório ou } \\
\text { manter tratamento continuo } \\
\text { para eliminar as fontes. }\end{array}$ \\
\hline Vinus & Hospedeiro humano. & $\begin{array}{l}\text { Adequar o número de } \\
\text { ocupantes por } \mathrm{m}^{2} \text { de área } \\
\text { com aumento da renovação } \\
\text { de ar, evitar a presença de } \\
\text { pessoas infectadas nos } \\
\text { ambientes climatizados }\end{array}$ \\
\hline Algas & $\begin{array}{l}\text { Torres de resfriamento e } \\
\text { bandejas de condensado. }\end{array}$ & $\begin{array}{l}\text { Higienizar os reservatónios } \\
\text { e bandejas de condensado } \\
\text { ou manter tratamento } \\
\text { continuo para eliminar as } \\
\text { fontes. }\end{array}$ \\
\hline Pólen & Ar extemo. & $\begin{array}{l}\text { Manter filtragem de acordo } \\
\text { com NBR-6401 da ABNT }\end{array}$ \\
\hline Artrópodes & Poeira caseira. & $\begin{array}{l}\text { Higienizar as } \\
\text { fixas e superficies } \\
\text { especialmente mobiliário, } \\
\text { revestidos com tecidos e } \\
\text { tapetes; restringir ou } \\
\text { eliminar o uso desses } \\
\text { revestimentos. }\end{array}$ \\
\hline Animais & $\begin{array}{l}\text { Roedores, morcegos e } \\
\text { aves. }\end{array}$ & $\begin{array}{l}\text { Restringir } 0 \text { acesso, } \\
\text { controlar os roedores, os } \\
\text { morcegos, ninhos de aves } \\
\text { e respectivos excrementos. }\end{array}$ \\
\hline
\end{tabular}

\section{QUADRO II}

Possiveis fontes de poluentes quimicos ${ }^{7}$

\begin{tabular}{|c|c|c|}
\hline $\begin{array}{c}\text { Agentes } \\
\text { químicos }\end{array}$ & $\begin{array}{l}\text { Principais fontes em } \\
\text { ambientes interiores }\end{array}$ & $\begin{array}{c}\text { Principais medidas de } \\
\text { correção em ambientes } \\
\text { interiores }\end{array}$ \\
\hline
\end{tabular}




\begin{tabular}{|c|c|c|}
\hline $\mathrm{CO}$ & $\begin{array}{l}\text { Combustão } \\
\text { queimadores de fogões e } \\
\text { veículos automotores). }\end{array}$ & $\begin{array}{l}\text { Manter a captação de ar } \\
\text { exterior com baixa } \\
\text { concentração de poluentes; } \\
\text { restringir as fontes de } \\
\text { combustão; manter a } \\
\text { exaustão em áreas em que } \\
\text { ocorre combustão; eliminar } \\
\text { a infiltração de Co } \\
\text { proveniente de fontes } \\
\text { externas; restringir o } \\
\text { tabagismo em áreas } \\
\text { fechadas. }\end{array}$ \\
\hline $\mathrm{CO}_{2}$ & $\begin{array}{l}\text { Produtos de metabolismo } \\
\text { humano e combustão. }\end{array}$ & $\begin{array}{l}\text { Aumentar a renovação de ar } \\
\text { externo; restringir as fontes } \\
\text { de combustão e o } \\
\text { tabagismo em áreas } \\
\text { fechadas; eliminar a } \\
\text { infiltração de fontes } \\
\text { extemas. }\end{array}$ \\
\hline $\mathrm{NO}_{2}$ & Combustāo. & $\begin{array}{llr}\text { Restringir as fontes de } & \text { de } \\
\text { combustão; } & \text { manter a } \\
\text { exaustão em áreas em que } \\
\text { ocorre combustão; impedir a } \\
\text { infiltração } & \text { de } r \mathrm{NO}_{2} \\
\text { proveniente } & \text { de fontes } \\
\text { extemas; } & \text { restringir } & \text { o } \\
\text { tabagismo } & \text { em } & \text { áreas } \\
\text { fechadas. } & & \end{array}$ \\
\hline $\mathrm{O}_{3}$ & $\begin{array}{l}\text { Máquinas copiadoras } \\
\text { impressoras a laser. }\end{array}$ & $\begin{array}{l}\text { Adotar medidas específicas } \\
\text { para reduzir a contaminação } \\
\text { dos ambientes interiores, } \\
\text { com exaustão do ambiente } \\
\text { ou enclausuramento em } \\
\text { locais exclusivos para os } \\
\text { equipamentos grande } \\
\text { apresentem } \\
\text { capacidade de produção de } \\
\mathrm{O}_{3 .}\end{array}$ \\
\hline Formaldeido & $\begin{array}{l}\text { Materiais de acabamento, } \\
\text { mobiliário, cola, produtos de } \\
\text { limpeza domissanitários }\end{array}$ & $\begin{array}{l}\text { Selecionar os materiais de } \\
\text { construçäo, acabamento e } \\
\text { mobiliário que possuam ou } \\
\text { emitam menos formaldeido; } \\
\text { usar produtos } \\
\text { domissanitários que não } \\
\text { contenham formaldeido. }\end{array}$ \\
\hline
\end{tabular}




\begin{tabular}{|c|c|c|}
\hline $\begin{array}{l}\text { Material } \\
\text { particulado }\end{array}$ & Poeira e fibras. & 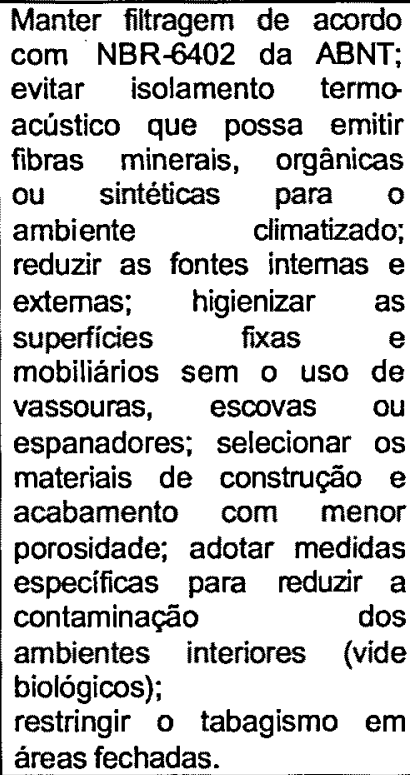 \\
\hline $\begin{array}{l}\text { Fumo de } \\
\text { tabaco }\end{array}$ & $\begin{array}{l}\text { Queima de cigarro, charuto, } \\
\text { cachimbo, etc. }\end{array}$ & $\begin{array}{l}\text { Aumentar a quantidade de } \\
\text { ar externo admitido para } \\
\text { renovaçäo e/ou exaustäo } \\
\text { dos poluentes; restringir o } \\
\text { tabagismo em àreas } \\
\text { fechadas. }\end{array}$ \\
\hline COV & $\begin{array}{l}\text { Cera, mobiliário, produtos } \\
\text { usados em limpeza e } \\
\text { domissanitários, solventes, } \\
\text { materiais de revestimento, } \\
\text { tintas, colas, etc. }\end{array}$ & $\begin{array}{l}\text { Selecionar os materiais de } \\
\text { construção, acabamento, } \\
\text { mobiliário; usar produtos de } \\
\text { limpeza e domissanitários } \\
\text { que não contenham COV ou } \\
\text { que não apresentem alta } \\
\text { taxa de volatilização e } \\
\text { toxicidade. }\end{array}$ \\
\hline $\cos -\mathrm{V}$ & $\begin{array}{l}\text { Queima de combustiveis e } \\
\text { utilização de pesticidas. }\end{array}$ & $\begin{array}{l}\text { Eliminar a contaminação por } \\
\text { fontes pesticidas, inseticidas } \\
\text { e a queima de combustiveis; } \\
\text { manter a captação de ar } \\
\text { exterior afastada de de } \\
\text { poluentes. }\end{array}$ \\
\hline
\end{tabular}

COV-Compostos Orgânicos Voláteis.

COS-V-Compostos Orgânicos Semi-Voláteis.

Observações - Os poluentes indicados são aqueles de maior ocorrência nos ambientes de interior, de efeitos conhecidos na saúde humana e de mais fácil deteç̧ão pela estrutura laboratorial existente no pais.

Outros poluentes que venham a ser considerados importantes serão incorporados aos indicados, desde que atendam ao disposto no parágrafo anterior.

\section{VI-AVALIAÇÃOE CONTRQLE}

Recomenda que sejam adotadas para fins de avaliação e controle do ar ambiental interior dos ambientes climatizados de uso coletivo, as seguintes Normas Técnicas 001, 002,003 e 004.

$\mathrm{Na}$ elaboração de relatórios técnicos sobre qualidade do ar interior, é recomendada a NBR-10.719 da ABNT Associação Brasileira de Normas.Técnicas.

1 World Health Organization. Indoor air quality: biological contaminants; Copenhagen, Denmark, 1983 ( European Series $\left.n^{\circ} 31\right)$.

2 American Society of Hearting, Refreigerating and Air Conditioning Engineers, Inc. ASHARAE Standard 62 Ventilation for Acceptable Indoor Air Quality, 2001

${ }_{3}^{3}$ Kulcsar Neto, F \& Siqueira, LFG. Padrões Referenciais para Análise de Resultados de Qualidade Microbiológica

do Ar em Interiores Visando a Saúde Pública no Brasil -Revista da Brasindoor .2 (10): 4-21,1999.

${ }_{5}^{4}$ Conselho Nacional do Meio Ambiente- CONAMA Resolução n.' 03 de 28/06 / 1990.

${ }^{5}$ ABNT - Associação Brasileira de Normas Técnicas, NBR 6401 - Instalaçōes Centrais de Ar Condicionado para

Conforto - Parâmetros Básicos de Projeto, 1980. 
${ }^{6}$ Siqueira, LFG \& Dantas, EHM. Organização e Métodos no Processo de Avaliaçāo da Qualidade do Ar de Interiores Revista da Brasindoor, 3 (1): 19-26, 1999.

${ }^{7}$ Aquino Neto, F.R; Brickus, LS.R. Padrōes Referenciais para Análise de Resultados da Qualidade Físico-química do Ar de Interior Visando a Saúde Pública. Revista da Brasindoor, 3(2):4-15,1999

\section{NORMA TECCNICA 001}

Qualidade do Ar Ambiental Interior. Método de Amostragem e Análise de Bioaerosol em Ambientes Interiores.

MÉTODO ANALITICO

OBJETIVO: Pesquisa, monitoramento e controle ambiental da possivel colonização, multiplicação e disseminação de fungos em ar ambiental interior.

DEFINIÇŌES:

Bioaerosol: Suspensão de microorganismos (organismos viáveis) dispersos no ar.

Marcador epidemiológico. Elemento aplicável à pesquisa, que determina a qualidade do ar ambiental.

APLICABILIDADE: Ambientes de interior climatizados, de uso coletivo, destinados a ocupações comuns (não especiais).

MARCADOR EPIDEMIOLÓGICO: Fungos viáveis.

MÉTODO DE AMOSTRAGEM: Amostrador de ar por impactação com acelerador linear.

PERIODICIDADE: Semestral.

FICHA TÉCNICA DO AMOSTRADOR:

Amostrador: Impactador de 1, 2 ou 6 estágios.

Meio de Cultivo: Agar Extrato de Malte, Agar Sabouraud Dextrose a 4\%, Agar Batata Dextrose ou outro, desde que cientificamente validado.

Taxa de Vazão:fixa entre 25 a $35 \mathrm{l} / \mathrm{min}$, sendo recomendada $28,3 \mathrm{l} / \mathrm{min}$.

Tempo de Amostragem: de 5 a 15 minutos, dependendo das especificações do amostrador. Volume Mínimo: 140 I

Volume Máximo: 5001

Embalagem: Rotina de embalagem para proteção da amostra com nivel de biossegurança 2 (recipiente lacrado, devidamente identificado com simbolo de risco biológico)

Transporte: Rotina de embalagem para proteção da amostra com nivel de biossegurança 2 (recipiente lacrado, devidamente identificado com símbolo de risco biológico)

Nota: Em áreas altamente contaminadas, pode ser recomendável uma amostragem com tempo e volume menores.

Calibração: Semestral

Exatidão: $\pm 0,02 \mathrm{l} / \mathrm{min}$.

Precisão: $\pm 99,92 \%$

\section{ESTRATÉGIA DE AMOSTRAGEM:}

- selecionar 01 amostra de ar exterior localizada fora da estrutura predial na altura de 1,50 m do nivel da rua.

- Definir o número de amostras de ar interior, tomando por base a área construída climatizada dentro de uma mesma edificação e razão social, seguindo a tabela abaixo:

\begin{tabular}{|c|c|}
\hline Área construída (m $\mathbf{m}^{\mathbf{Y}}$ & Número mínimo de amostras \\
\hline Até 1.000 & 1 \\
\hline 1.000 a 2.000 & 3 \\
\hline 2.000 a 3.000 & 5 \\
\hline 3.000 a 5.000 & 8 \\
\hline 5.000 a 10.000 & 12 \\
\hline 10.000 a 15.000 & 15 \\
\hline 15.000 a 20.000 & 18 \\
\hline 20.000 a 30.000 & 21 \\
\hline Acima de 30.000 & 25 \\
\hline
\end{tabular}

- as unidades funcionais dos estabelecimentos com caracteristicas epidemiológicas diferenciadas, tais como serviço médico, restaurantes, creches e outros, deveräo ser amostrados isoladamente.

- os pontos amostrais deverão ser distribuidos uniformemente e coletados com o amostrador localizado na altura de $1,5 \mathrm{~m}$ do piso, no centro do ambiente ou em zona ccupada.

PROCEDIMENTO LABORATORIAL: Método de cultivo e quantificação segundo normatizações universalizadas. Tempo minimo de incubação de 7 dias a $25^{\circ} \mathrm{C}$., permitindo o total crescimento dos fungos. 
BIBLIOGRAFIA: "Standard Methods for Examination of Water and Wastewater".

17 th ed. APHA, AWWA, WPC.F; "The United States Pharmacopeia". USP, XXIII ed., NF XVIII, 1985.

NIOSH- National institute for Occupational Safety and Health, NIOSH Manual of Analytical Methods (NMAM), BIOAEROSOL SAMPLING (Indoor Air) 0800, Fourth Edition.

IRSST - Institute de Recherche en Santé et en Securité du Travail du Quebec, Canada, 1994.

Members of the Technicael Advisory Committee on Indoor Air Quality, Commission of Public Health Ministry of the Environment - Guidelines for Good Indoor Air Quality in Office Premises, Singapore.

\section{NORMA TÉCNICA 002}

Qualidade do Ar Ambiental Interior. Método de Amostragem e Análise da Concentração de Dióxido de Carbono em Ambientes Interiores.

\section{MÉTODO ANALITICO}

OBJETIVO: Pesquisa, monitoramento e controle do processo de renovação de ar em ambientes climatizados.

APLICABILIDADE: Ambientes interiores climatizados, de uso coletivo.

MARCADOR EPIDEMIOLÓGICO: Dióxido de carbono $\left(\mathrm{CO}_{2}\right)$.

MÉTODO DE AMOSTRAGEM: Equipamento de leitura direta.

PERIODICIDADE: Semestral.

FICHA TÉCNICA DOS AMIOSTRADORES:

\begin{tabular}{|c|c|}
\hline $\begin{array}{l}\text { Amostrador: Leitura Direta p } \\
\text { dispersivo ou célula eletroquimica. }\end{array}$ & or meio de sensor infravermelho não \\
\hline $\begin{array}{lll}\text { Calibração: } & \text { Anual ou } & \text { de } \\
\text { acordo com } & \text { especificação } & \text { do } \\
\text { fabricante. } & & \\
\end{array}$ & $\begin{array}{l}\text { Faixa: de } 0 \text { a } 5.000 \mathrm{ppm} \text {. } \\
\text { Exatidão: } \pm 50 \mathrm{ppm}+2 \% \text { do valor } \\
\text { medido }\end{array}$ \\
\hline
\end{tabular}

\section{ESTRATÉGIA DE AMOSTRAGEM:}

- Definir o número de amostras de ar interior, tomando por base a área construída climatizada dentro de uma mesma edificação e razão social, seguindo a tabela abaixo:

\begin{tabular}{|c|c|}
\hline Área construída $\left(\mathbf{m}^{2}\right)$ & Número mínimo de amostras \\
\hline Até 1.000 & 1 \\
\hline 1.000 a 2.000 & 3 \\
\hline 2.000 a 3.000 & 5 \\
\hline 3.000 a 5.000 & 8 \\
\hline 5.000 a 10.000 & 12 \\
\hline 10.000 a 15.000 & 15 \\
\hline 15.000 a 20.000 & 18 \\
\hline 20.000 a 30.000 & 21 \\
\hline Acima de 30.000 & 25 \\
\hline
\end{tabular}

- as unidades funcionais dos estabelecimentos com características epidemiológicas diferenciadas, tais como serviço médico, restaurantes, creches e outros, deverão ser amostrados isoladamente.

- os pontos amostrais deverão ser distribuídos uniformemente e coletados com o amostrador localizado na altura de $1,5 \mathrm{~m}$ do piso, no centro do ambiente ou em zona ocupada.

PROCEDIMENTO DE AMOSTRAGEM: As medidas deverão ser realizadas em horários de pico de utilização do ambiente.

\section{NORMA TÉCNICA 003}

Qualidade do Ar Ambiental Interior. Método de Amostragem. Determinação da Temperatura, Umidade e Velocidade do Ar em Ambientes Interiores.

\section{MÉTODO ANALITICO}

OBJETIVO: Pesquisa, monitoramento e controle do processo de climaização de ar em ambientes climatizados.

APLICABILIDADE: Ambientes interiores climatizados, de uso coletivo. 
MARCADORES: Temperatura do $\operatorname{ar}\left({ }^{\circ} \mathrm{C}\right)$

Umidade do ar (\%)

Velocidade do $a r(\mathrm{~m} / \mathrm{s})$.

MÉTODO DE AMOSTRAGEM: Equipamentos de leitura direta. Termo-higrômetro e Anemômetro.

PERIODICIDADE: Semestral.

FICHA TÉCNICA DOS AMOSTRADORES:

Amostrador: Leitura Direta-Termohigrômetro.

Princípio de operação: Sensor de temperatura do tipo termo-resistência.

Sensor de umidade do tipo capacitivo ou por condutividade elétrica.

Calibração: Anual

Faixa: $0^{\circ} \mathrm{C}$ a $70^{\circ} \mathrm{C}$ de temperatura $5 \%$ a $95 \%$ de umidade

Exatidão: $\pm 0,8^{\circ} \mathrm{C}$ de temperatura

umidade

$\pm 5 \%$ do valor medido de

Amostrador: Leitura Direta - Anemômetro.

Principio de operação: Preferencialmente de sensor de velocidade do ar do tipo fio aquecido ou fio térmico.

\begin{tabular}{|l|l|}
\hline Calibração: Anual & $\begin{array}{l}\text { Faixa: de } 0 \text { a } 10 \mathrm{~m} / \mathrm{s} \\
\text { Exatidão: } \pm 0,1 \mathrm{~m} / \mathrm{s} \pm 4 \% \text { do valor medido }\end{array}$ \\
\hline
\end{tabular}

\section{ESTRATÉGIA DE AMOSTRAGEM:}

- Definir o número de amostras de ar interior, tomando por base a área construída climatizada dentro de uma mesma edificaçäo e razão social, seguindo a tabela abaixo:

\begin{tabular}{|c|c|}
\hline Área construída $\left(\mathrm{m}^{2}\right)$ & Número mínimo de amostras \\
\hline Até 1.000 & 1 \\
\hline $1.000 \mathrm{a} 2.000$ & 3 \\
\hline $2.000 \mathrm{a} 3.000$ & 5 \\
\hline $3.000 \mathrm{a} 5.000$ & 8 \\
\hline $5.000 \mathrm{a} 10.000$ & 12 \\
\hline $10.000 \mathrm{a} 15.000$ & 15 \\
\hline $15.000 \mathrm{a} 20.000$ & 18 \\
\hline $20.000 \mathrm{a} 30.000$ & 21 \\
\hline Acima de 30.000 & 25 \\
\hline
\end{tabular}

- as unidades funcionais dos estabelecimentos com características epidemiológicas diferenciadas, tais como serviço médico, restaurantes, creches e outros, deverão ser amostrados isoladamente.

- os pontos amostrais deverão ser distribuidos uniformemente e coletados com o amostrador localizado na altura de $1,5 \mathrm{~m}$ do piso, no centro do ambiente ou em zona ocupada, para o Termohigrômetro e no espectro de ação do difusor para o Anemômetro.

\section{Norma Técnica 004}

Qualidade do Ar Ambiental Interior. Método de Amostragem e Análise de Concentração de Aerodispersóides em Ambientes Interiores.

\section{MÉTODO ANALITICO}

OBJETIVO: Pesquisa, monitoramento e controle de aerodispersóides totais em ambientes interiores climatizados.

APLICABILIDADE: Ambientes de interior climatizados, de uso coletivo, destinados a ocupaçōes comuns (não especiais).

MARCADOREPIDEMIOLÓGICO: Poeira Total $\left(\mu \mathrm{g} / \mathrm{m}^{3}\right)$.

MÉTODO DE AMOSTRAGEM: Coleta de aerodispersóides por filtração (MB -3422 da ABNT).

PERIODICIDADE: Semestral.

FICHA TÉCNICA DO AMOSTRADOR: 
Amostrador: Unidade de captação constituida por filtros de PVC, diâmetro de $37 \mathrm{~mm}$ e porosidade de $5 \mu \mathrm{m}$ de diâmetro de poro específico para poeira total a ser coletada; Suporte de filtro em disco de celulose; Portafiltro em plástico transparente com diâmetro de $37 \mathrm{~mm}$.

Aparelhagem: Bomba de amostragem, que mantenha ao longo do periodo de coleta, a vazão inicial de calibração com variação de $5 \%$.

Taxa de Vazão: 1,0 a 3,0 Vmin, recomendado 2,0 $\mathrm{l} / \mathrm{min}$.

Volume Minimo: 501

Volume Máximo: 400 I

Tempo de Amostragem: relação entre o volume captado e a taxa de vazão utilizada

Embalagem: Rotina

Calibração: Em cada procedimento de coleta Exatidão: $\pm 5 \%$ do valor

se operado com bombas diafragmáticas $\quad$ medido

ESTRATÉGIA DE AMOSTRAGEM:

- Definir o número de amostras de ar interior, tomando por base a área construída climatizada dentro de uma mesma edificação e razão soçial, seguindo a tabela abaixo:

\begin{tabular}{|c|c|}
\hline Área construida $\left(\mathbf{m}^{2}\right)$ & Nümero minimo de amostras \\
\hline Até 1.000 & 1 \\
\hline 1.000 a 2.000 & 3 \\
\hline 2.000 a 3.000 & 5 \\
\hline 3.000 a 5.000 & 8 \\
\hline 5.000 a 10.000 & 12 \\
\hline 10.000 a 15.000 & 15 \\
\hline 15.000 a 20.000 & 18 \\
\hline 20.000 a 30.000 & 21 \\
\hline Acima de 30.000 & 25 \\
\hline
\end{tabular}

- as unidades funcionais dos estabelecimentos com caracteristicas epidemiológicas diferenciadas, tais como serviço médico, restaurantes, creches e outros, deverão ser amostrados isoladamente.

- os pontos amostrais deverão ser distribuidos uniformemente e coletados com o amostrador localizado na altura de 1,5 m do piso, no centro do ambiente ou em zona ocupada.

PROCEDIMENTO DE COLETA: MB-3422 da ABNT.

PROCEDIMENTO DE CALIBRACÃA DAS BOMBAS: NBR- 10.562 da ABNT

PROCEDIMENTO LABORATORIAL: NHO 17 da FUNDACENTRO

\section{VII - INSPEÇÃO}

Recomenda que os órgãos competentes de Vigilância Sanitária com o apoio de outros órgãos governamentais, organismos representativos da comunidade e dos ocupantes dos ambientes climatizados, utilizem esta Orientação Técnica como instrumento técnico referencial, na realização de inspeções e de outras ações pertinentes nos ambientes climatizados de uso público e coletivo.

\section{VII-RESPONSABILIDADE TÉCNICA}

Recomenda que os proprietários, locatários e prepostos de estabelecimentos com ambientes ou conjunto de ambientes dotados de sistemas de climatização com capacidade igual ou supenior a 5 TR $(15.000 \mathrm{kcal} / \mathrm{h}=60.000 \mathrm{BTU} / \mathrm{h})$, devam manter um responsável técnico atendendo ao determinado na Portaria GM/MS $n^{\circ} 3.523 / 98$, além de desenvolver as seguintes atribuiçōes:

a) providenciar a avaliação biológica, química e física das condições do ar interior dos ambientes climatizados;

b) promover a correção das condições encontradas, quando necessária, para que estas atendam ao estabelecido no Art. $4^{\circ}$ desta Resolução;

c) manter disponivel o registro das avaliações e correções realizadas; e

d) divulgar aos ocupantes dos ambientes climatizados os procedimentos e resultados das atividades de avaliação, correção e manutenção realizadas.

Em relação aos procedimentos de amostragem, medições e análises laboratoriais, considera-se como responsável técnico, o profissional que tem competência legal para exercer as atividades descritas, sendo profissional de nivel superior com habilitação na área de quimica (Engenheiro químico, Quimico e Farmacêutico) e na área de biologia (Biólogo, Farmacêutico e Biomédico) em conformidade com a regulamentação profissional vigente no país e comprovação de Responsabilidade Técnica -RT, expedida pelo Órgäo de Classe.

As análises laboratoriais e sua responsabilidade técnica devem obrigatoriamente estar desvinculadas das atividades de limpeza, manutenção e comercialização de produtos destinados ao sistema de climatização. 
Anexo 2-

Exemplo de cromatograma obtido de análise pelo modo SCAN 
Data Acquired by
Acquisition Date
Sample Type

Level\#

Sample Name

Sample ID

IS Amount

Sample Amount

Dilution Factor

Vial \#

Injection Volume

Data File

Method File

Report File

Tuning File

amostra

Admin

20/11/2002 11:22:56

Unknown

$: 0$

: amostra1

; 1$]=0.000$

0.000

0.000

$: 1$

1.000

C:IGCMSsolutionISamplelamostra1ascanQGD.QGD

C:IGCMSsolutionISampleltese1.qgm

C:LCMSsolutionISystemITune1L20-11-02.9gt

\section{Análise SCAN \\ SCAN}

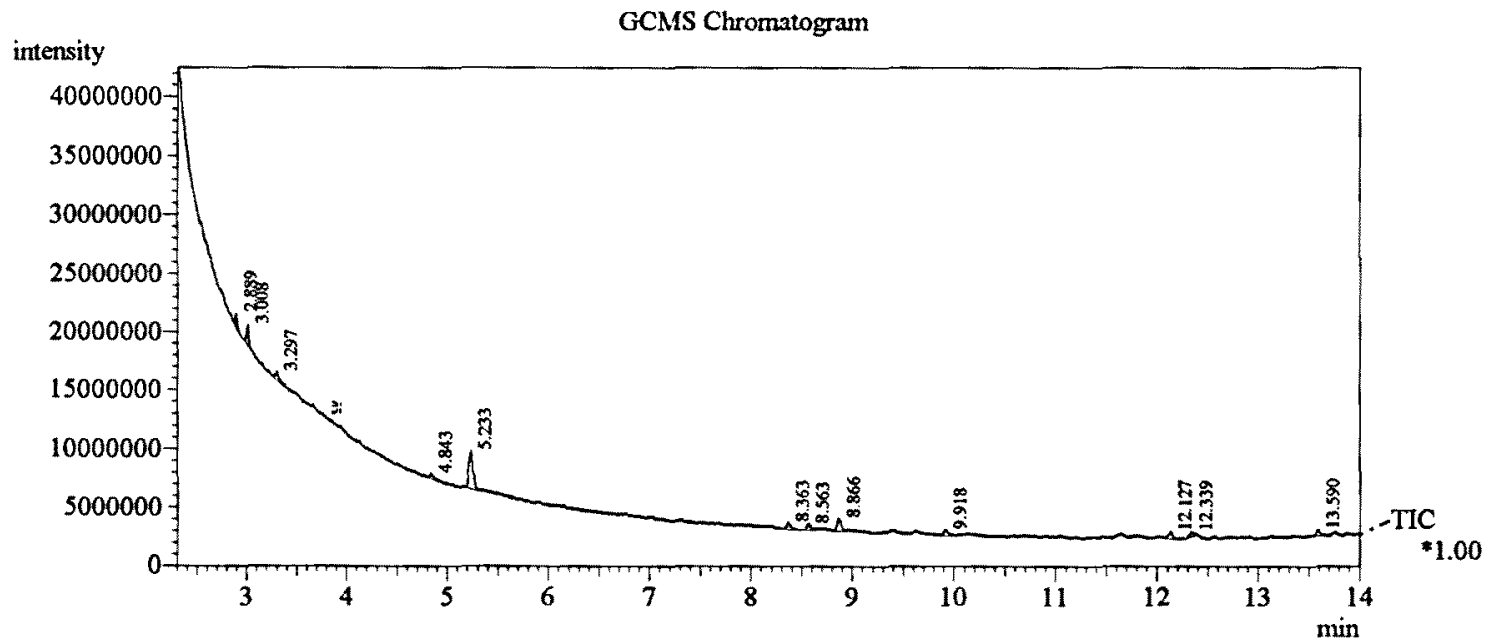




\section{Anexo 3-}

Exemplo de cromatograma obtido de análise de benzeno pelo modo SIM 

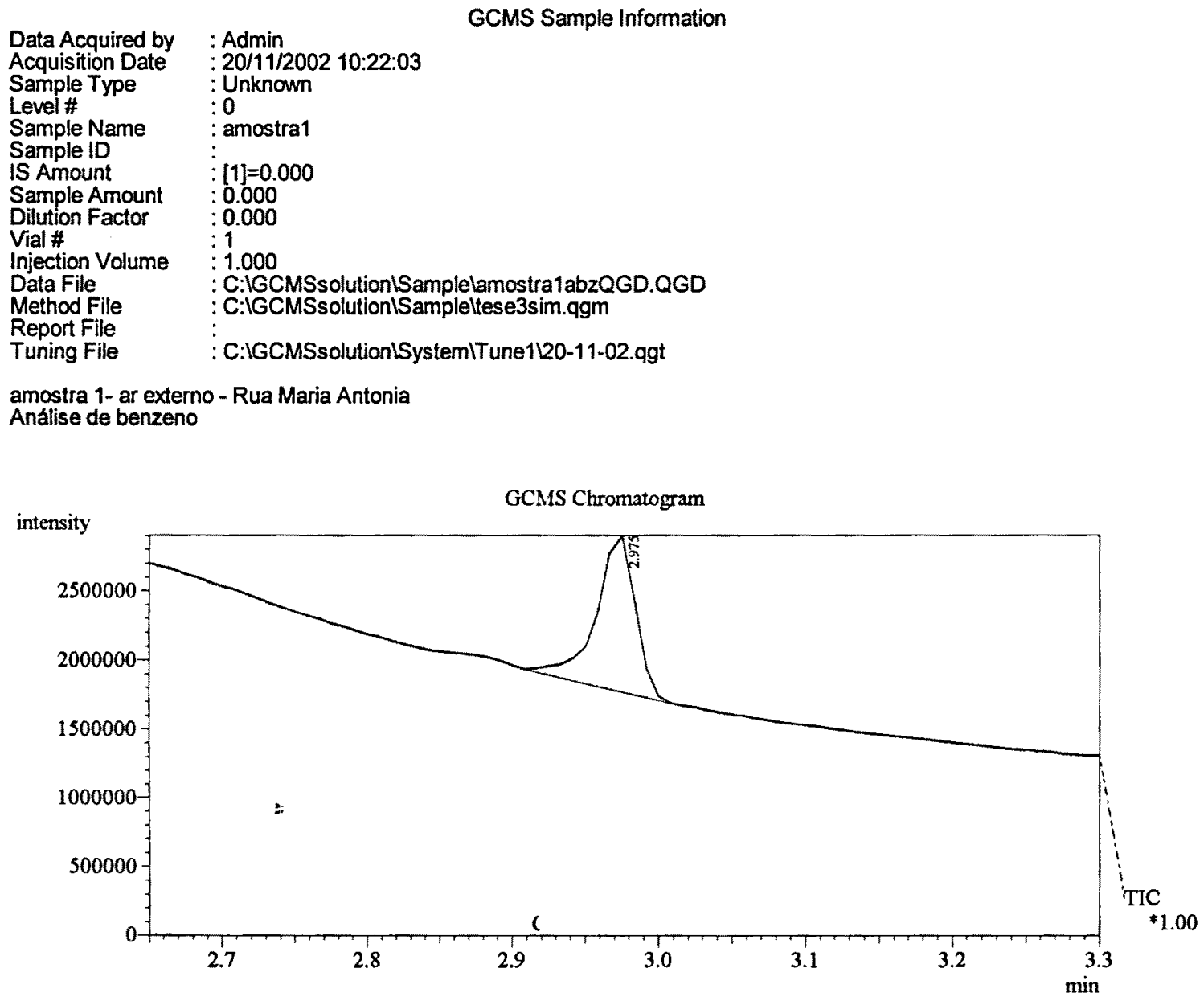

GCMS Peak Report

$\begin{array}{rrrrrrrr}\text { Peak\# } & \text { R.Time } & \text { I.Time } & \text { F.Time } & \text { Area } & \text { Height } & \text { A/H } & \text { Mark } \\ 1 & 2.975 & 2.908 & 3.008 & 2065933 & 1121344 & 1.84 & \text { V }\end{array}$


Anexo 4-

Exemplo de cromatograma obtido de análise de tolueno pelo modo SIM 

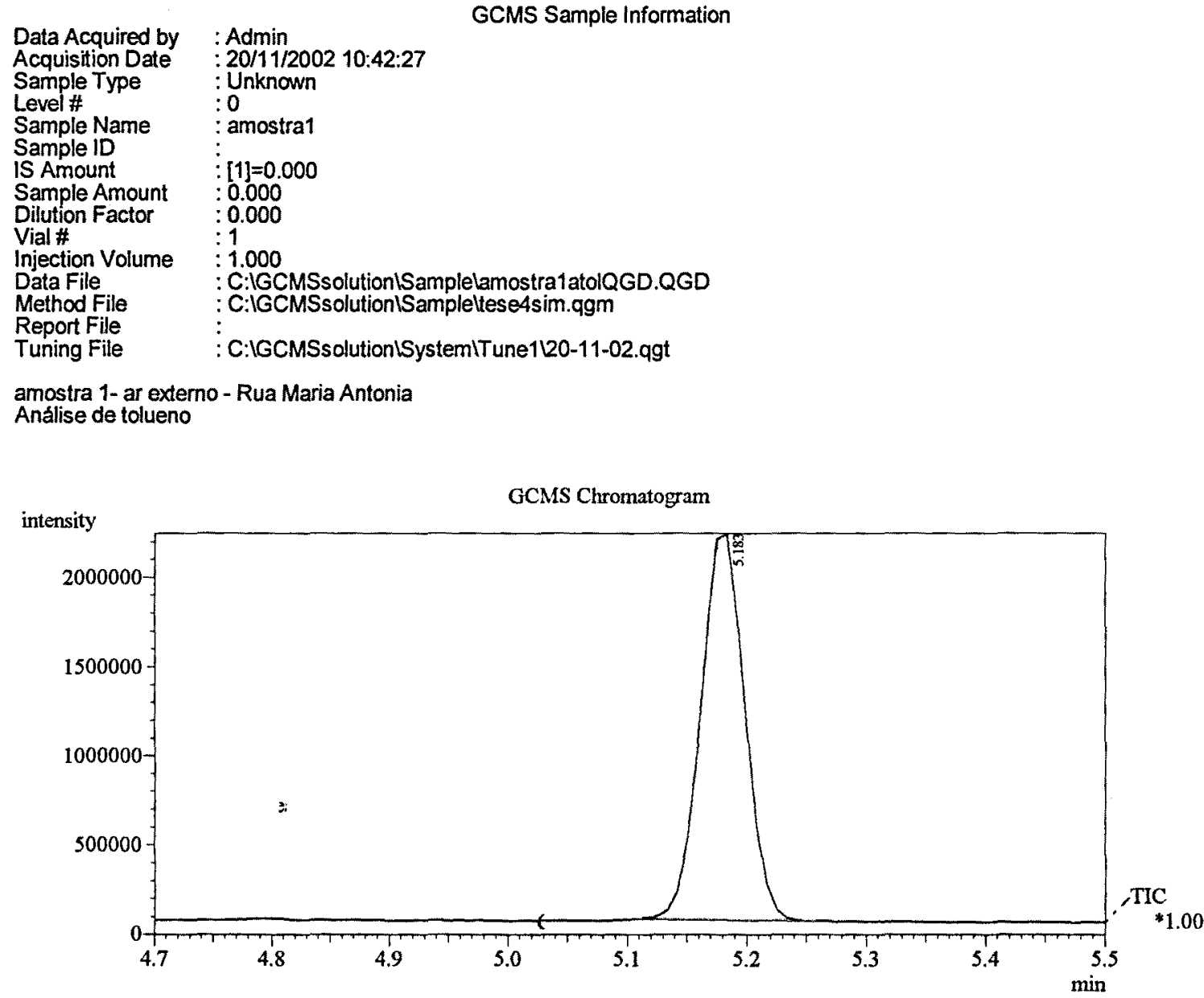

$\begin{array}{rrrrrrrc}\text { Peak\# } & \text { R.Time } & \text { I.Time } & \text { F.Time } & \text { Area } & \text { Height } & \text { A/H } & \text { Mark } \\ 1 & 5.183 & 5.108 & 5.258 & 5561642 & 2159900 & 2.57 & \text { V }\end{array}$


Anexo 5-

Exemplo de cromatograma obtido de análise de clorofórmio pelo modo SIM 


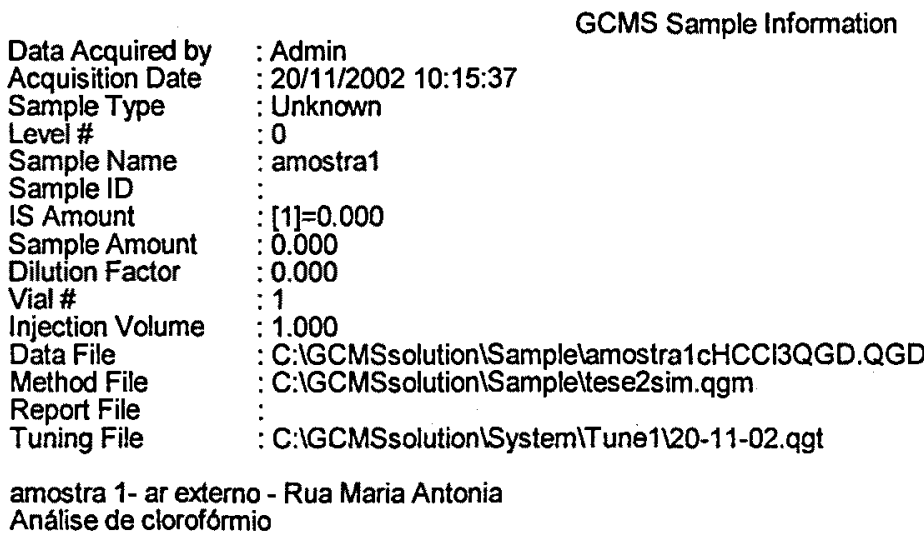

Tuning File

amostra 1- ar externo - Rua Maria Antonia

Análise de clorofórmio

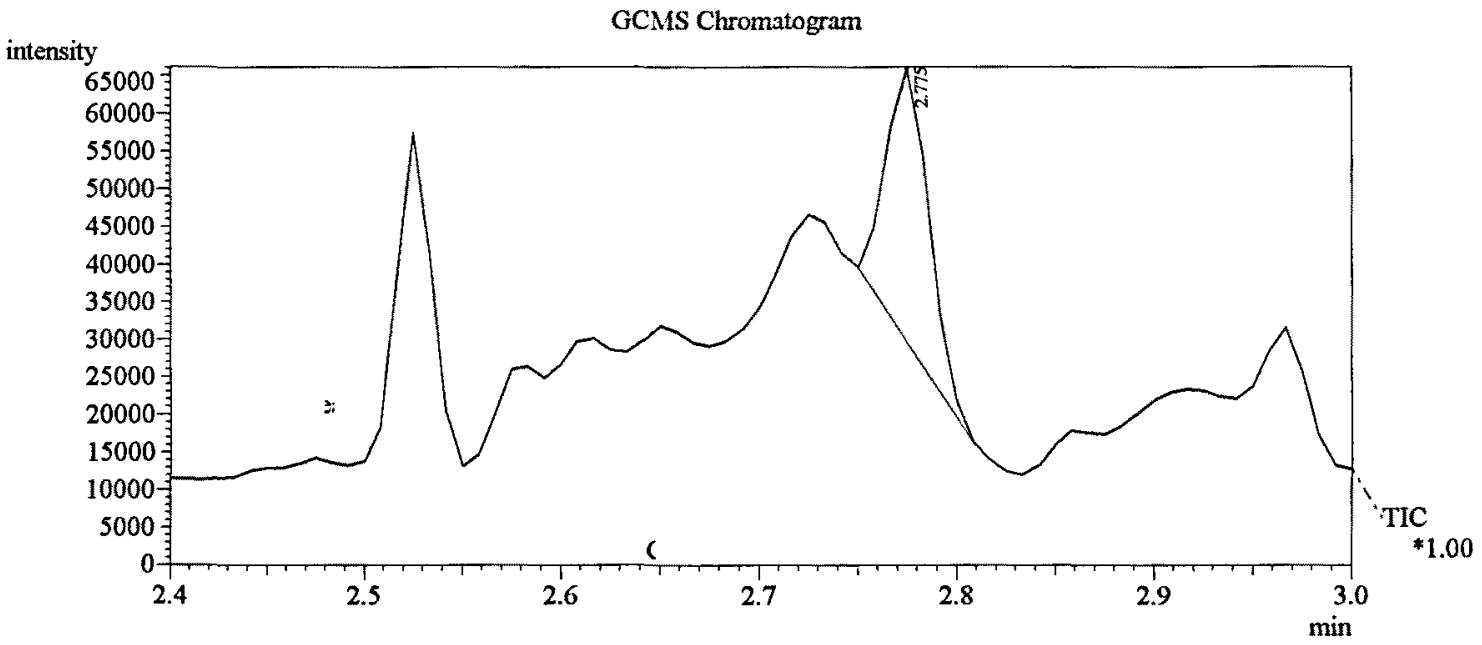

$\begin{array}{rrrrrrrr}\text { Peak\# } & \text { R.Time } & \text { I.Time } & \text { F.Time } & \text { Area } & \text { Height } & \text { A/H } & \text { Mark } \\ 1 & 2.775 & 2.750 & 2.808 & 55134 & 36330 & 1.52 & \text { V }\end{array}$


Anexo 6-

Exemplo de cromatograma obtido de análise de tetracloreto de carbono pelo modo SIM 


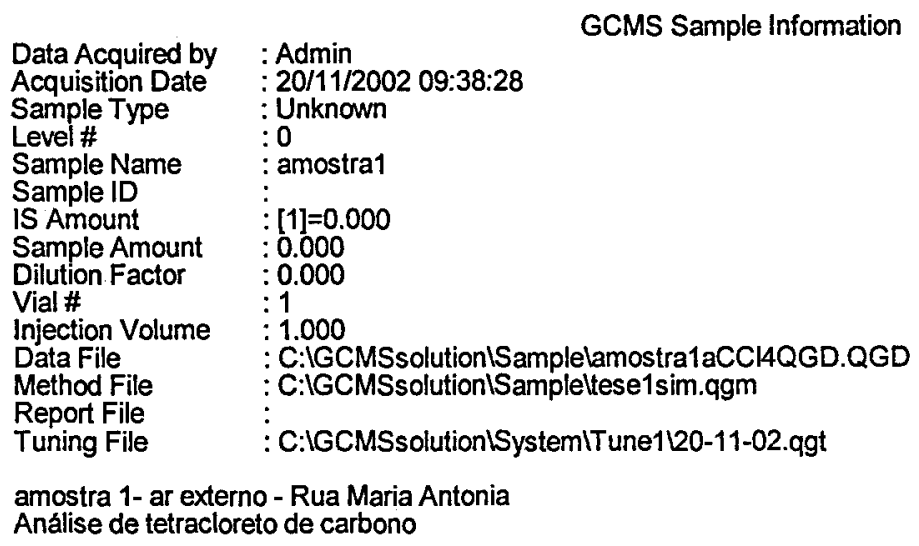

amostra 1- ar externo - Rua Maria Antonia

Análise de tetracloreto de carbono

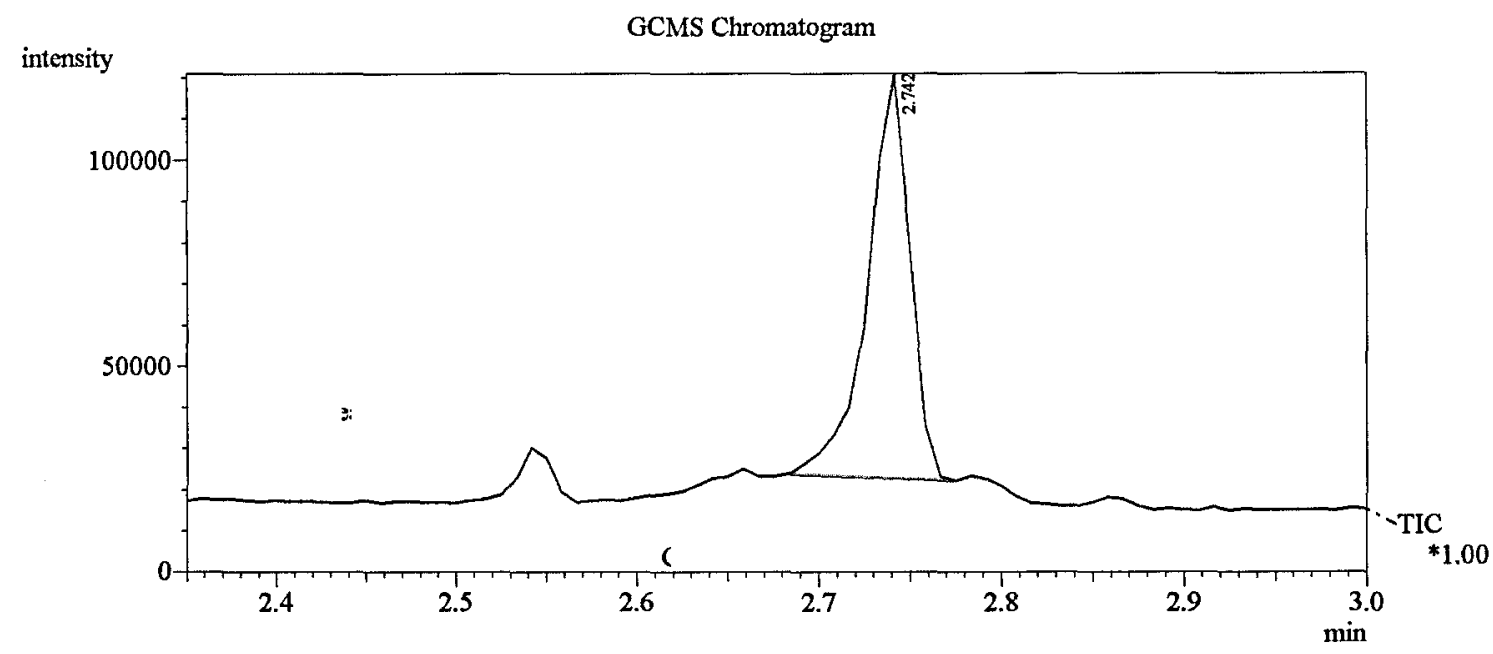

GCMS Peak Report

$\begin{array}{rrrrrrrr}\text { Peak\# } & \text { R.Time } & \text { I.Time } & \text { F.Time } & \text { Area } & \text { Height } & \text { A/H } & \text { Mark } \\ 1 & 2.742 & 2.683 & 2.775 & 158329 & 97922 & 1.62 & \mathrm{~V} \\ & & & & 158329 & 97922 & & \end{array}$

